DOE/AL/62350-215

REV. 0

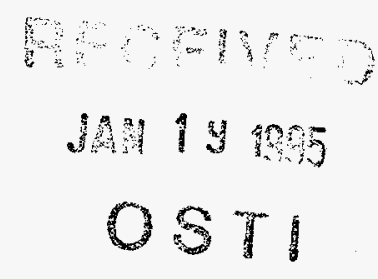

\title{
Site Observational Work Plan For the UMTRA ProJect Site AT Grand Junction, Colorado
}

January 1996 
INTENDED FOR PUBLIC RELEASE

This report has been reproduced from the best available copy. Available in paper copy and microfiche.

Number of pages in this report: 186

DOE and DOE contractors can obtain copies of this report from:

Office of Scientific and Technical Information

P.O. Box 62

Oak Ridge, TN 37831

(615) 576-8401

This report is publicly available from:

National Technical Information Service

Department of Commerce

5285 Port Royal Road

Springfield, VA 22161

(703) $487-4650$

\section{DISCLAIMER}

This report was prepared as an account of work sponsored by an agency of the United States Government. Neither the United States Government nor any agency thereof, nor any of their employees, makes any warranty, express or implied, or assumes any legal liability or responsibility for the accuracy, completeness, or usefulness of any information, apparatus, product, or process disclosed, or represents that its use would not infringe privately owned rights. Reference herein to any specific commercial product, process, or service by trade name, trademark, manufacturer, or otherwise does not necessarily constitute or imply its endorsement, recommendation, or favoring by the United States Government or any agency thereof. The views and opinions of authors expressed herein do not necessarily state or reflect those of the United States Government or any agency thereof. 


\section{DISCLAMMER}

Portions of this document may be illegible in electronic image products. Images are produced from the best available original document. 
REV. 0

\title{
SITE OBSERVATIONAL WORK PLAN FOR THE UMTRA PROJECT SITE AT \\ GRAND JUNCTION, COLORADO
}

\author{
January 1996
}

Work Performed Under DOE Contract No. DE-AC04-91AL62350

Prepared for

U.S. Department of Energy

Albuquerque Operations Office

Grand Junction Projects Office

Prepared by

Jacobs Engineering Group Inc.

Albuquerque, New Mexico 


\section{EXECUTIVE SUMMARY}

The U.S. Department of Energy (DOE) has prepared this initial site observational work plan (SOWP) for the Uranium Mill Tailings Remedial Action (UMTRA) Project site in Grand Junction, Colorado. This SOWP is one of the first UMTRA Ground Water Project documents developed to select a compliance strategy that meets the UMTRA ground water standards (40 CFR Part 192, as amended by 60 FR 2854) for the Grand Junction site. This SOWP applies information about the Grand Junction site to the compliance strategy selection framework developed in the UMTRA Ground Water Project draft programmatic environmental impact statement (PEIS) (DOE, 1995a). This risk-based, decision-making framework identifies the decision logic for selecting compliance strategies that could be used to meet the ground water standards.

The DOE goal is to implement a cost-effective site strategy that complies with the ground water standards and protects human health and the environment. Based on an evaluation of the site characterization and risk assessment data available for the preparation of this SOWP, DOE proposes that the most likely compliance strategy for the Grand Junction site is no remediation with the application of supplemental standards. This proposed strategy is based on a conceptual site model that indicates site-related contamination is confined to a limited-use aquifer as defined in the ground water standards.

The DOE developed the conceptual site model by evaluating available site-specific and regional data. There are two aquifers beneath the site: a surficial, unconfined alluvial aquifer underlain by a shale formation, which acts in part as an aquitard, and a deeper confined sandstone aquifer underlying the shale. There is an upward vertical gradient from the confined aquifer to the unconfined alluvial aquifer. The conceptual model demonstrates that the uranium processing-related contamination at the site has affected the unconfined alluvial aquifer, but not the deeper confined aquifer. The contamination in the alluvial aquifer appears to be migrating west and southwest of the site until the ground water eventually discharges to the Colorado River.

Evaluation of DOE data and studies published by others indicate that ground water in the alluvial aquifer is of limited use with the total dissolved solids in the alluvial aquifer most likely exceeding 10,000 milligrams per liter and widespread, ambient contamination that did not result from activities involving residual radioactive materials. There is no current known use of ground water crossgradient or downgradient of the site in the area impacted by uranium processing activities. Assessments of human health and ecological risk indicate that use of background ground water could have adverse effects.

Additional data still are needed to confirm that the alluvial aquifer qualifies for supplemental standards and that supplemental standards will be protective of human health and the environment. These data will help define the regional background ground water quality, the impacts of recharge from local canals and drainage ditches on the background water quality near the site, the impacts of contaminant discharge to the Colorado River, and whether organic compounds used during uranium processing are present in the ground water. These data then will be used to refine the conceptual site model and the potential human health and environmental risks of the proposed strategy. 
The SOWP process provides stakeholders a forum for review and comment on the proposed compliance strategy. The proposed strategy that emerges in the final SOWP will be evaluated in a site-specific environmental assessment to determine environmental impacts, which will permit further stakeholder input. When the final ground water compliance strategy is accepted, it will be detailed in a compliance strategy plan or remedial action plan that will be subject to review by the state of Colorado and concurrence by the U.S. Nuclear Regulatory Commission. 


\section{TABLE OF CONTENTS}

Section

EXECUTIVE SUMMARY

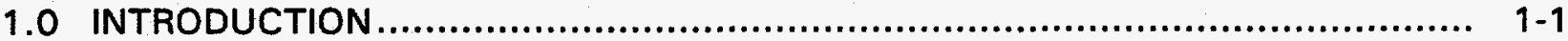

1.1 Proposed compliance strategy ................................................. 1-1

1.2 Relationship to programmatic documents...................................... $1-2$

1.3 Relationship to site-specific documents ........................................ $1-2$

1.4 Revision process ................................................................ $1-2$

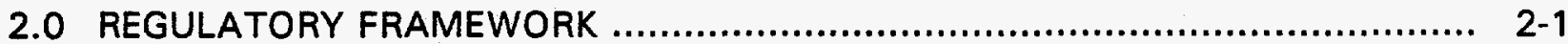

2.1 Uranium Mill Tailings Radiation Control Act..................................... $2-1$

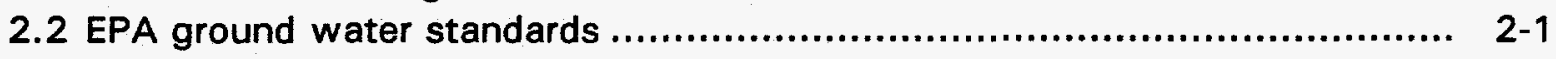

2.3 National Environmental Policy Act............................................... $2-3$

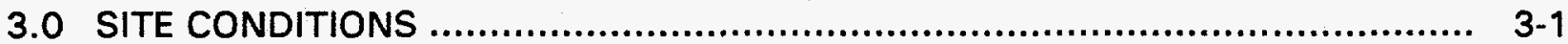

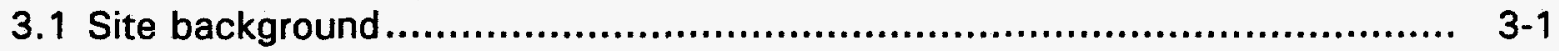

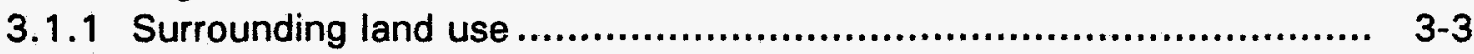

3.1 .2 Surrounding water use.................................................... $3-3$

3.1.3 Contaminant sources.................................................... $3-5$

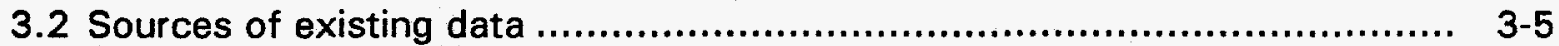

3.3 Conceptual site model ............................................................ $3-8$

3.4 Physical setting and geology .................................................... 3-11

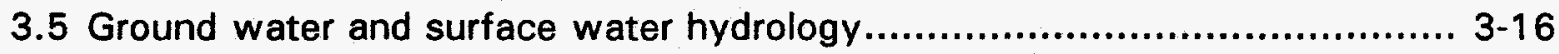

3.5.1 Regional ground water hydrology ........................................ $3-16$

3.5.2 Local ground water hydrology ............................................ 3-20

3.5.3 Surface water-ground water interaction................................... 3-27

3.6 Geochemistry .................................................................. $3-32$

3.6.1 Background ground water quality .................................... 3-32

3.6.2 Uranium processing and process solutions ............................... 3-36

3.6.3 Magnitude and extent of ground water contamination................... 3-42

3.6.4 Surface water quality ....................................................... 3-46

3.6.5 Contaminants of potential concern ........................................ 3-50

3.6.6 Fate and transport of contaminants of potential concern ............... 3-50

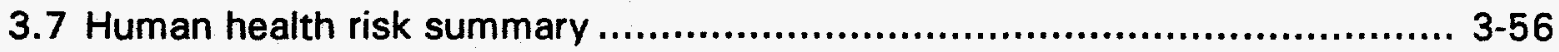

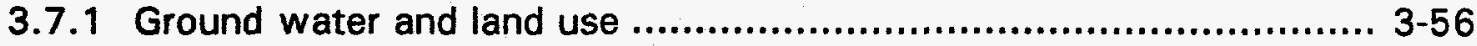

3.7.2 Methods ..................................................................... 3-56

3.7.3 Potential impacts from contaminated ground water..................... 3-57

3.7.4 Potential impacts from background ground water ....................... 3-58

3.7.5 Potential public health impacts from drinking background ground water.......................................................................... 399

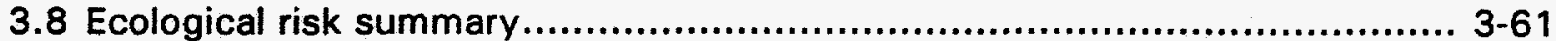

3.8.1 Methods ..................................................................... 3-63

3.8.2 Potential ecological impacts ............................................... 3-63

3.9 Evaluation of interim remedial action needs...................................... $3-80$ 


\section{TABLE OF CONTENTS (Concluded)}

Section

Page

4.0 GROUND WATER COMPLIANCE STRATEGY SELECTION $\ldots \ldots \ldots \ldots \ldots \ldots \ldots \ldots \ldots \ldots, 4-1$

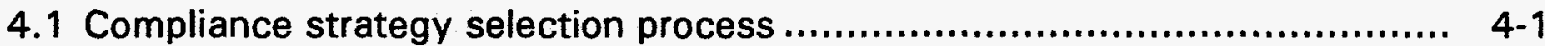

4.2 Grand Junction compliance strategy selection.................................. 4-1

4.3 Deviations and contingencies ..................................................... 4-4

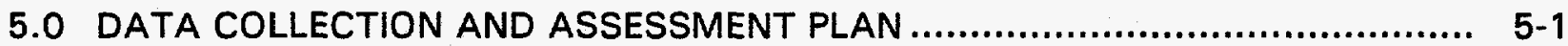

5.1 Statement of primary data needs ............................................... $5-1$

5.1.1 Evaluation of the Government Highline Canal ............................. 5-1

5.1.2 Mass flow and dilution factors for the Colorado River .................... $5-2$

5.1.3 Collection of regional data on background ground water quality ....... $5-2$

5.1 .4 Investigation of organic contamination .................................. $5-2$

5.1.5 Evaluation of available public water supply treatment capabilities..... $5-3$

5.2 Assessment of data and reporting .............................................. $5-3$

5.3 Statement of secondary data needs .............................................. $5-4$

5.3.1 Investigation of the current distribution of ground water contamination.............................................................. $5-4$

5.3.2 Evaluation of vicinity properties ......................................... $5-5$

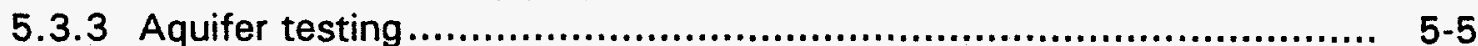

5.3.4 Topographic surveying ................................................... $5-6$

5.3 .5 Monitoring ground water quality ....................................... $5-6$

5.3.6 Ground water and surface water level elevation monitoring ............ 5-6

5.3.7 Geochemical analysis of ground water and aquifer matrix.............. $5-6$

5.3.8 Toxicological literature review .......................................... $5-7$

5.3.9 Computer modeling of ground water flow .............................. $5-7$

5.3.10 Feasibility of implementing institutional controls ....................... $5-8$

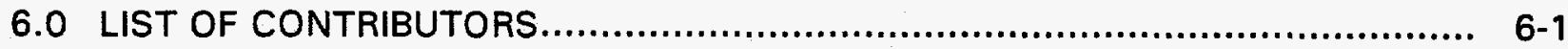

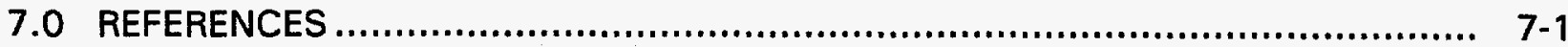

APPENDIX A LITHOLOGIC LOGS, WELL COMPLETION RECORDS, WELL CONSTRUCTION DATA

APPENDIX B TOXICITY RANGES 


\section{LIST OF FIGURES}

Figure

Page

3.1 Location of Grand Junction, Colorado, site

3.2 Land use map, Grand Junction, Colorado, site vicinity

3.3 Locations of existing and decommissioned monitor wells, Grand Junction, Colorado, site vicinity.

3.4 Isopach map of the fill/alluvium, Grand Junction, Colorado, site vicinity

3.5 Generalized geologic cross section of the Grand Valley, Colorado.

3.6 Structure contour map of the top of the Mancos Shale Formation, Grand Junction, Colorado, site vicinity

3.7 Generalized hydrogeologic cross section of the uppermost formations within the Grand Valley, Grand Junction, Colorado.

3.8 Locations of major canals and ditches, vicinity of Grand Junction,

Colorado

3.9 Water table contour map (alluvial aquifer), 28 February through

7 March 1989, Grand Junction, Colorado, site vicinity

3.10 Hydrogeologic cross section location map, Grand Junction, Colorado, site vicinity

3.11 Geologic cross section A-A', Grand Junction, Colorado, site vicinity............. 3-25

3.12 Geologic cross section B-B', Grand Junction, Colorado, site vicinity ............ 3-26

3.13 Ground water and surface water level hydrographs (10/19/94-9/5/95),

Grand Junction, Colorado, site

3.14 Ranges of downhole specific conductance of water from selected wells in Grand Valley, June-July 1991, Grand Junction, Colorado, site vicinity .......

3.15 Distribution of uranium in alluvial ground water in the Grand Junction, Colorado, site vicinity

3.16 Surface water and sediment sample locations, locations of wetland ponds as they appeared in November 1994, Grand Junction, Colorado, site vicinity

4.1 Compliance strategy selection process, Grand Junction, Colorado, site 


\section{LIST OF TABLES}

Table

Page

3.1 DOE ground water monitor well completion and historical sampling data for the Grand Junction, Colorado, site.

3.2 Slug withdrawal test results in the Mancos Shale and Dakota Sandstone at the Grand Junction, Colorado, site

3.3 Water level elevations and relative vertical potentials of ground water well clusters at the Grand Junction, Colorado, site

3.4 Summary of filtered ground water quality at the Grand Junction, Colorado, site

3.5 Major chemicals used at the former Climax mill in Grand Junction, Colorado

3.6 Typical tailings lysimeter and upgradient water quality for the Grand Junction, Colorado, site

3.7 Concentrations of selected contaminants in water from the January 1995 sampling of ponds at the Grand Junction, Colorado, site

3.8 Contaminants of potential concern for human health evaluation, Grand Junction, Colorado, site

3.9 Aqueous species of contaminants of potential concern in the alluvial aquifer at the Grand Junction, Colorado, site

3.10 Comparison of concentrations of contaminants in the Grand Junction, Colorado, site vicinity to federal standards.

3.11 Point exposure dose and cancer risk estimates for background ground water ingestion pathway, Grand Junction, Colorado, site 


\section{LIST OF ACRONYMS}

\section{Acronym Definition}

$\begin{array}{ll}\text { ac } & \text { acre } \\ \text { ACL } & \text { alternate concentration limit } \\ \text { BLRA } & \text { baseline risk assessment } \\ \text { cm/s } & \text { centimeter per second } \\ \text { DOE } & \text { U.S. Department of Energy } \\ \text { Eh } & \text { redox potential } \\ \text { EPA } & \text { U.S. Environmental Protection Agency } \\ \mathrm{ft} & \text { foot } \\ \mathrm{ft} / \mathrm{s} & \text { foot per second } \\ \text { gal/m } & \text { gallons per cubic meter } \\ \text { ha } & \text { hectare } \\ \mathrm{kg} & \text { kilogram } \\ \mathrm{km} & \text { kilometer } \\ \text { L/day } & \text { liters per day } \\ \text { m } & \text { meter } \\ \text { mi } & \text { mile } \\ \text { MCL } & \text { maximum concentration limit } \\ \text { mg/L } & \text { milligram per liter } \\ \text { mS/cm } & \text { microsiemens per centimeter } \\ \text { MSL } & \text { mean sea level } \\ \text { mV } & \text { millivolt } \\ \text { NEPA } & \text { National Environmental Policy Act } \\ \text { NRC } & \text { U.S. Nuclear Regulatory Commission } \\ \text { PEIS } & \text { programmatic environmental impact statement } \\ \text { RAP } & \text { remedial action plan } \\ \text { SOWP } & \text { site observational work plan } \\ \text { TDS } & \text { total dissolved solids } \\ \text { UMTRA } & \text { Uranium Mill Tailings Remedial Action } \\ \text { UMTRCA } & \text { Uranium Mill Tailings Radiation Control Act } \\ \text { USACE } & \text { U.S. Army Corps of Engineers } \\ \text { USBR } & \text { U.S. Bureau of Reclamation } \\ \text { USGS } & \text { U.S. Geological Survey } \\ & \end{array}$




\subsection{INTRODUCTION}

The U.S. Department of Energy (DOE) Uranium Mill Tailings Remedial Action (UMTRA) Ground Water Project employs the "observational approach" to ensure that technically and financially sound ground water compliance strategies are selected at UMTRA Project sites. The observational approach uses existing site data to develop a conceptual model of the "most probable" site conditions and appropriate strategies for achieving compliance with the U.S. Environmental Protection Agency (EPA) ground water standards (40 CFR Part 192, as amended by 60 FR 2854). This approach permits the acquisition of additional site data and the development of contingency plans to deal with deviations from anticipated conditions. The observational approach links a cost-effective remedial action option with effective contingency planning that will result in full regulatory compliance and protection of human health and the environment without the burden of excessive site characterization and conservatism.

The DOE prepares site-specific site observational work plans (SOWP) to document the observational approach employed at UMTRA Ground Water Project sites. The SOWPs will be used in conjunction with a variety of other programmatic and site-specific documents to select and implement the final ground water compliance strategy for each site. Due to the nature of the observational approach, the development of a SOWP is an iterative process requiring one or more revisions before a final compliance strategy is selected.

\subsection{PROPOSED COMPLIANCE STRATEGY}

The DOE has applied the observational approach at the former Climax uranium mill site in Grand Junction, Colorado (hereinafter referred to as the Grand Junction site). After evaluating currently available site-specific and regional information, the DOE proposes a ground water compliance strategy of no remediation with the application of supplemental standards based on data indicating the contamination is confined to a limited-use aquifer as defined in the ground water standards.

This SOWP describes the DOE's initial use of the observational approach for the Grand Junction site to propose the most likely strategy for complying with the EPA ground water standards and to recommend additional data collection efforts needed to select a final ground water compliance strategy. Section 2.0 describes the regulatory framework that governs the selection and implementation of a ground water compliance strategy for UMTRA Ground Water Project sites. Salient elements of the ground water standards that relate specifically to the proposed compliance strategy are discussed. Section 3.0 defines the current conditions at the Grand Junction site based on existing characterization data, presents potential human health and ecological risks, and presents the conceptual site model. Section 4.0 provides the decision-making framework used to arrive at the proposed ground water compliance strategy. Potential deviations from the conceptual site model, which could impact the selection of the proposed compliance strategy, are also discussed along with contingency plans for addressing deviations. Section 5.0 presents a data 
collection and assessment plan that identifies primary and secondary data needs, data collection and data quality objectives, and proposed field activities necessary to refine the conceptual site model and select a final compliance strategy.

\subsection{RELATIONSHIP TO PROGRAMMATIC DOCUMENTS}

Programmatic documents that provide guidance for the SOWP include the UMTRA Ground Water Project plan (DOE, 1993a), the draft programmatic environmental impact statement for the UMTRA Ground Water Project (PEIS) (DOE, 1995a), and the Technical Approach to Ground Water Restoration (DOE, 1993b). The project plan states the mission, need, and objectives for the UMTRA Ground Water Project and provides an overall technical plan and management approach for conducting the UMTRA Ground Water Project. The draft PEIS provides an objective programmatic decision-making framework for conducting the UMTRA Ground Water Project, assesses the potential programmatic impacts of conducting the Project, provides a method for determining the site-specific ground water compliance strategies, and provides data and information that can be used to analyze site-specific environmental impacts more efficiently. The technical approach document provides general technical guidance for conducting the UMTRA Ground Water Project.

\subsection{RELATIONSHIP TO SITE-SPECIFIC DOCUMENTS}

The Grand Junction remedial action plan (RAP) provides detailed site characterization information (DOE, 1991). The DOE has used this information along with data obtained subsequent to the preparation of the RAP to formulate the conceptual site model presented in Section 3.3. If the final ground water compliance strategy for this site requires remedial action, the DOE will prepare a ground water RAP or surface RAP modification. If remedial action is not required, the DOE will prepare a compliance strategy plan for the site.

The baseline risk assessment (BLRA) prepared for the Grand Junction site identifies potential public health and environmental risks (DOE, 1995b). This SOWP considers these potential risks and site-specific data interpreted after the BLRA was completed, ensuring the most likely compliance strategy is protective of human health and the environment.

Finally, a site-specific National Environmental Policy Act (NEPA) (42 USC $\$ 4321$ et seq.) document (most likely an environmental assessment) will be prepared to determine any potential impacts of implementing the proposed compliance strategy.

\subsection{REVISION PROCESS}

The Grand Junction SOWP will be revised periodically to incorporate the results of future data collection efforts and analyses. At least two versions (this initial version and the final SOWP) of the Grand Junction SOWP will be prepared. This 
initial SOWP (Revision 0) evaluates all current information about the site, develops a conceptual site model, proposes the most likely compliance strategy based on current knowledge, and identifies additional data needs. Following stakeholder review and resolution of comments, fieldwork will be conducted to collect additional data.

The next revision of the SOWP will evaluate the additional data collected, address any resultant changes in the conceptual site model and the proposed compliance strategy based on the new information, and summarize the results related to the data collection objectives. If additional data needs are identified, further revisions of the SOWP may be required. If no additional data needs are identified and stakeholder comments are relatively minor, a final SOWP will be prepared.

The final SOWP will present the final compliance strategy and will document the data collection activities and applicable modeling results. The final revision will be prepared after review by affected stakeholders and comment resolution. 


\subsection{REGULATORY FRAMEWORK}

This SOWP recommends the strategy for the Grand Junction site that most likely will result in compliance with the EPA ground water standards applicable to DOE UMTRA Project processing sites (40 CFR Part 192, Subparts B and C, as revised by 60 FR 2854). The relationship of the Uranium Mill Tailings Radiation Control Act (UMTRCA) (42 USC $\$ 7901$ et seq.), the EPA standards, the DOE cooperative agreement with the state of Colorado (DOE, 1981), and the NEPA (42 USC \$4321 et seq.) to the UMTRA Ground Water Project is described below.

\section{$2.1 \quad$ URANIUM MILL TAILINGS RADIATION CONTROL ACT}

The U.S. Congress passed the UMTRCA in 1978 in response to public concerns about the potential health hazards from exposure to uranium mill tailings. The UMTRCA requires the stabilization, disposal, and control of uranium mill tailings and other contaminated materials at uranium mill processing sites.

Title I of the UMTRCA

- Designates 24 inactive uranium processing sites to undergo remediation.

- Mandates remedial action in accordance with the standards prescribed by the EPA.

- Directs the DOE to select and perform remedial action, including ground water remediation activities, with the concurrence of the U.S. Nuclear Regulatory Commission (NRC) and in consultation with states and Indian tribes.

- Directs the NRC to license the disposal sites for long-term care.

The DOE has a cooperative agreement with the state of Colorado to perform surface remedial action at designated processing sites in Colorado, including the Grand Junction site (DOE, 1981). This agreement may be extended to cover Ground Water Project activities or a new agreement may be developed.

\subsection{EPA GROUND WATER STANDARDS}

The EPA has promulgated standards (40 CFR Part 192, as amended by 60 FR 2854) for protecting human health and the environment from hazardous constituents associated with uranium processing and the resulting residual radioactive materials. These standards address two ground water contamination scenarios: 1) future ground water contamination that may be caused by tailings piles after disposal cell construction, and 2) contamination that occurred before disposal of the tailings piles. The UMTRA Surface Project addresses future protection of the ground water at the disposal sites with the 
design of disposal cells and long-term surveillance plans. The UMTRA Ground Water Project addresses the residual contamination that occurred at the former processing sites before the surface remedial action was completed and is regulated by Subparts $B$ and $C$ of the EPA standards.

Subpart $B$ requires that remedial action at processing sites is conducted to ensure the levels of contaminants in ground water meet any one of the three following specified criteria:

- Background level. Constituent concentration in the uppermost aquifer that was not affected by uranium processing activities.

- Maximum concentration limit (MCL). The maximum limit for the concentration of a listed constituent in ground water. Table 1 of 40 CFR Part 192 gives the MCLs for constituents that apply to UMTRA Project sites.

- Alternate concentration limit (ACL). Alternative limit for the concentration of a constituent that does not pose a substantial present or potential future hazard to human health or the environment, as long as the limit is not exceeded. An ACL may be applied after considering options to achieve background levels or MCLs.

The DOE, with the concurrence of the NRC, may apply supplemental standards to contaminated ground water in lieu of background levels, MCLs, or ACLs under certain conditions specified in the regulations. Supplemental standards may be applicable for the Grand Junction site if the contaminated ground water meets the criteria for limited use. Subpart B defines "limited use" as ground water that is not a current or potential source of drinking water because 1) the concentration of total dissolved solids (TDS) is in excess of 10,000 milligrams per liter (mg/L); or 2) widespread, ambient contamination, not due to activities involving residual radioactive materials from a designated processing site, exists that cannot be cleaned up using treatment methods reasonably employed in public water systems; or 3) the quantity of water reasonably available for sustained continuous use is less than 150 gallons (gal) $\left(0.57\right.$ cubic meters $\left.\left[\mathrm{m}^{3}\right]\right)$ per day.

The DOE may employ either natural flushing or active remedial procedures as a way of meeting the EPA standards. Natural flushing lets natural processes reduce the ground water contamination to background levels, MCLs, or ACLs. In addition, ground water must not be a current or projected source of drinking water during the natural flushing period. Institutional controls (measures that restrict access to contamination, protect human health and the environment, and satisfy beneficial uses of ground water) must be established and maintained during the natural flushing period, which must not exceed 100 years.

Subpart $\mathrm{C}$ provides guidance for implementing methods and procedures, including the application of supplemental standards, that will reasonably assure 
the provisions of Subpart B are satisfied. Subpart $C$ requires that a site-specific plan for meeting the applicable requirements of Subpart B be developed using information gathered from site characterization and monitoring. The plan should contain the compliance strategy, a demonstration of effectiveness, and a monitoring program, if required.

\subsection{NATIONAL ENVIRONMENTAL POLICY ACT}

The UMTRA Ground Water Project is a major federal action subject to the requirements of the NEPA (42 USC $\$ 4321$ et seq.). The Council on Environmental Quality's regulations that implement the NEPA are codified in 40 CFR Parts 1500-1508. These regulations require each federal agency to develop its own implementing procedures. The DOE NEPA regulations are contained in 10 CFR Part 1021; further guidance is provided in DOE Order 451.1 .

Pursuant to the NEPA, the DOE drafted an UMTRA Ground Water Project PEIS to analyze the potential impacts of implementing four programmatic alternatives for ground water compliance at the UMTRA Project designated processing sites (DOE, 1995a). The DOE will select the preferred alternative, which will be published in a "record of decision." All subsequent Ground Water Project activity must comply with this record of decision. The environmental impacts from implementing the proposed compliance strategy presented in the final Grand Junction SOWP will be addressed in a site-specific document that will meet NEPA requirements. 


\subsection{SITE CONDITIONS}

This section provides background information on the Grand Junction site, presents the conceptual site model, and summarizes current site characterization knowledge with respect to geology, hydrology, geochemistry, and potential human health and ecological risks used to develop the conceptual model.

\subsection{SITE BACKGROUND}

The Grand Junction site is in Mesa County, in west-central Colorado near the Colorado-Utah border. The site is adjacent to the north side of the Colorado River in an industrial area of the city of Grand Junction (Figure 3.1).

The Climax Uranium Company, which was incorporated into American Metals Climax, Inc., in 1960, processed uranium and vanadium ore at the Grand Junction site from June 1951 to March 1970. The Climax mill processed ore at the rate of 330 tons ( 300 metric tons) per day between 1951 and 1955 . In 1955 the capacity was increased to 500 tons (450 metric tons) per day, and the mill operated at this rate until it closed in 1970 . The ore processed by the Climax mill was crushed, ground, and treated to extract the product. The mill was dismantled and the tailings pile was stabilized during late 1970 to early 1971.

Merritt (1971) indicates that the most probable water usage during ore processing was 500 gal per ton of ore $\left(2 \mathrm{~m}^{3}\right.$ per metric ton). Based on 300 operating days per year, the water-use rate between 1951 and 1955 was approximately 50 million gal/year $\left(190,000 \mathrm{~m}^{3} /\right.$ year), and between 1955 and 1970 the water-use rate was approximately 75 million gal/year $(285,000$ $\mathrm{m}^{3} /$ year). Much of this process water was discharged to on-site evaporation ponds.

From 1951 to 1966 , approximately 300,000 tons $(272,000$ metric tons) of tailings were removed from the site and used as construction material or earth fill at many locations (termed "vicinity properties") in the Grand Junction area. Contaminated materials subsequently remediated from these vicinity properties were returned to the site for storage pending removal for permanent disposal. The state of Colorado currently owns the former mill site.

Surface remedial action at the site was conducted in two phases. Phase 1 remedial action involved fencing, constructing lined retention ponds, and preparing the wastewater treatment plant foundation at the site. Phase I was completed in 1989. Phase II began in 1990 and included constructing the disposal cell and assembling the wastewater treatment plant. Residual radioactive material excavation and removal to the Cheney disposal site started in the spring of 1991. Removal of the residual radioactive material from the Grand Junction site was completed in 1994. Part of the remedial action involved constructing wetlands, including eight ponds, along the southern 


\section{Location of Grand Junction, Colorado, Site}
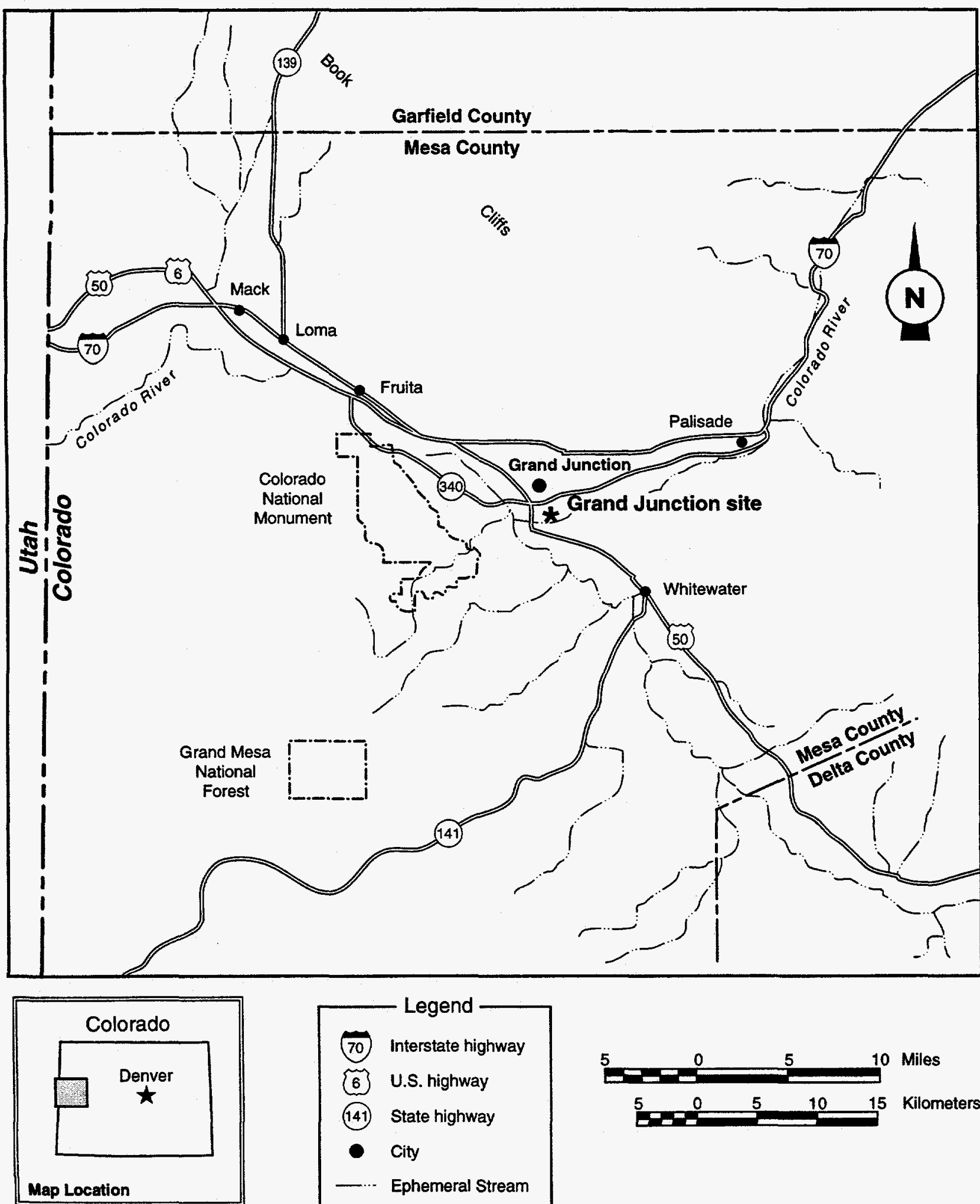

\section{Legend}

(70) Interstate highway

(6) U.S. highway

(141) State highway

- City

\section{-... Ephemeral Stream}

MAC: SITE/GRJ/SOWP/REGIONALMAP

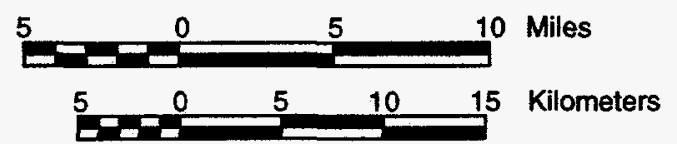


boundary of the processing site. The U.S. Army Corps of Engineers (USACE) is constructing a flood control levee through the site vicinity. Levee construction was scheduled for completion in 1995.

\subsubsection{Surrounding land use}

The Grand Junction site is in a primarily urbanized area, with residential, commercial, and commercial/industrial uses (Figure 3.2). Residential land use in the site vicinity is limited to areas west and northeast of the site and south of the Colorado River. The Denver and Rio Grande Western Railroad, situated approximately 0.5 mile (mi) $(0.8$ kilometer [ $\mathrm{km}])$ north of the site, is approximately the northern boundary of the industrial use area. Residential land use becomes much more prevalent about $0.25 \mathrm{mi}(0.5 \mathrm{~km})$ north of the railroad tracks. Commercial and industrial land uses occur immediately north and east of the site. Large tracts of vacant land and land used for agricultural purposes are further east of the site. The Grand Valley By-Products Company, located near the southeastern boundary of the site, is a rendering plant that has been processing animal parts and by-products for nearly 100 years.

\subsubsection{Surrounding water use}

The Grand Junction zoning and development code requires that all development be served by the city water treatment and distribution system. In the site vicinity and in the majority of the surrounding Grand Valley area, surface water supplies municipal and industrial needs. Most of the water for the Grand Valley originates as surface water high on the Grand Mesa. During times of drought, water may be obtained from the Gunnison River about $1 \mathrm{mi}(1.6 \mathrm{~km})$ upstream from its confluence with the Colorado River. Colorado River water from upstream of the Grand Junction site is used in irrigation canals that cross the Grand Valley upgradient from the site. No other major users of Colorado River water reside in the Grand Junction site vicinity (DOE, 1986).

Examination of current databases and intensive field reconnaissance downgradient and crossgradient from the Grand Junction site indicates that no known users of the alluvial ground water are within the area affected by contamination from the site. The Mancos Shale, which underlies the alluvium in the site vicinity, is not considered a ground water source in the Grand Junction area. The Dakota Sandstone, which underlies the Mancos Shale, is the uppermost artesian aquifer in the site vicinity. No registered wells are known to be completed in the Dakota Sandstone within the area potentially affected by contamination from the site. No future domestic use of shallow ground water in the affected hydrogeologic environment is anticipated, due to the availability of city water and the low quality of ground water in the alluvial aquifer. Also, no future use of ground water in the Dakota Sandstone is anticipated due to the poor water quality. Ground water quality and use are discussed in more detail in Sections 3.6 and 3.7 . 
SITE OBSERVATIONAL WORK PLAN FOR THE

UMTRA PROJECT SITE AT GRAND JUNCTION, COLORADO

SITE CONDITIONS

\section{Figure 3.2}

\section{Land Use Map}

Grand Junction, Colorado, Site Vicinity
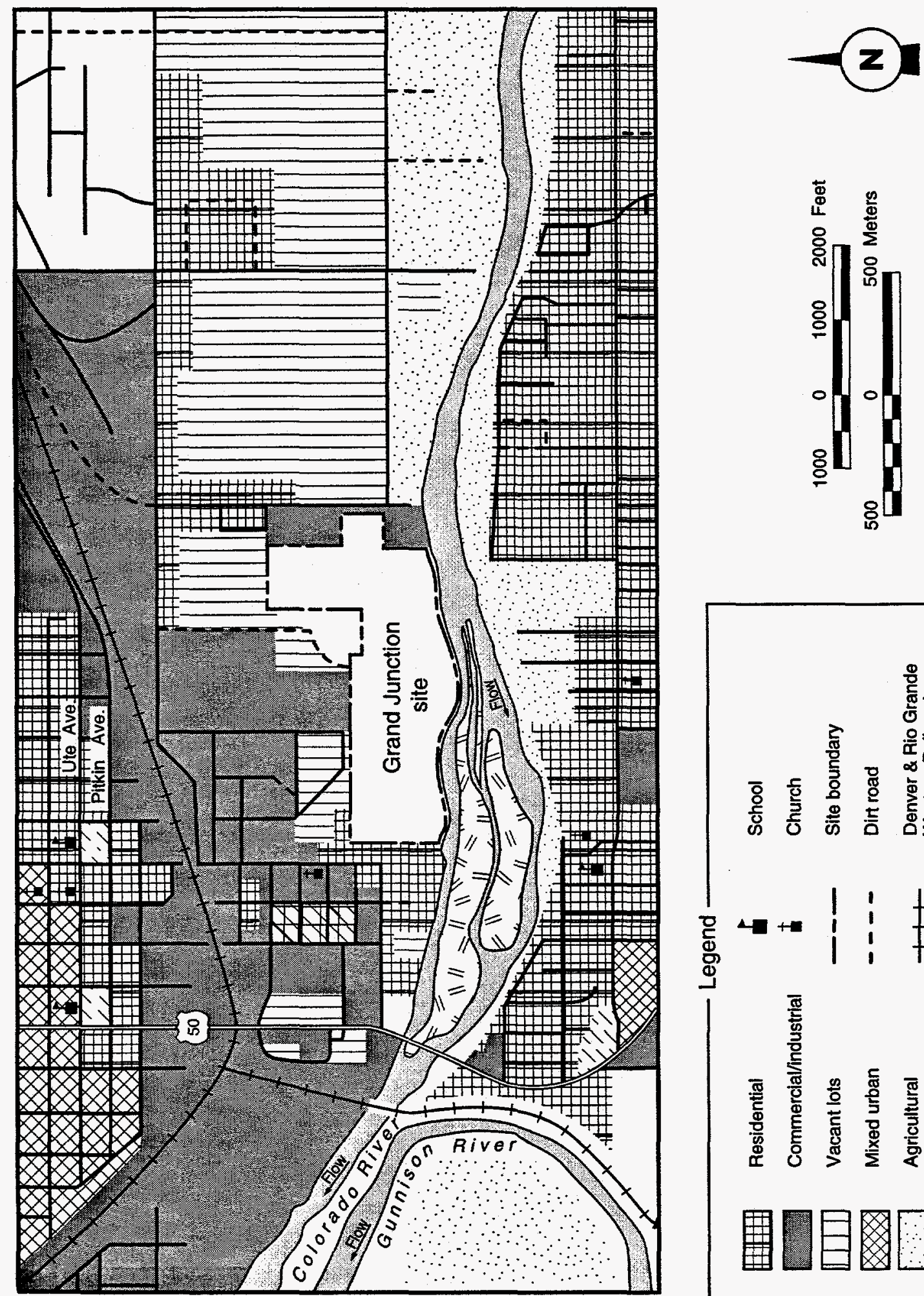

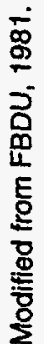
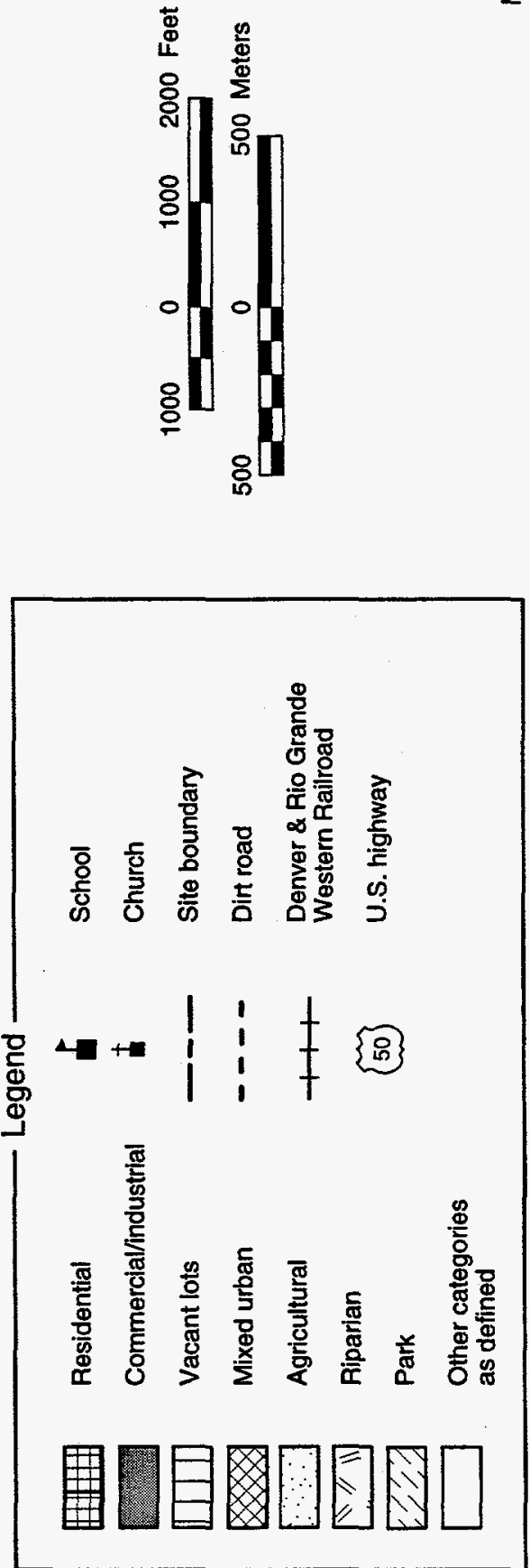

MAC: SITE/GRJ/SOWPRANDUSE 


\subsubsection{Contaminant sources}

The primary sources of contamination at the Grand Junction site were from uranium mill tailings and process water. During operation, the mill produced 2.2 million tons ( 2 million metric tons) of tailings, which were placed in a tailings pile that covered much of the western two-thirds of the site (DOE, 1986; 1991). The thickness of the former tailings pile ranged from approximately 10 to 50 feet ( $\mathrm{ft}$ ) ( 3 to 15 meters [m]). In addition to the main tailings pile, contaminated material resulting from vicinity property remediation was placed in the former evaporation ponds on the eastern portion of the site.

The mill's 35 ac (14 ha) of evaporation ponds were not adequate for evaporating the estimated quantity of water used during ore processing. Based on Grand Junction's mean annual total precipitation of 17 inches (43 centimeters $[\mathrm{cm}])$, less the average lake and pan evaporation rate of 45 inches/year $(110 \mathrm{~cm} /$ year), the average annual pond water evaporation would only have been 27 million gal $\left(100,000 \mathrm{~m}^{3}\right)$. It is assumed that the difference between the water used at the mill and that lost to evaporation would have seeped from the ponds into the shallow alluvial aquifer. The seepage rate of water from the ponds into the alluvial aquifer is estimated to be 22.5 million gal/year $\left(85,500 \mathrm{~m}^{3} /\right.$ year) between 1951 and 1955 , and $48 \mathrm{million}$ gal/year $\left(180,000 \mathrm{~m}^{3} /\right.$ year) between 1955 and 1970 . Based on these estimates and the assumption that all process water either evaporated or seeped from the ponds, the total amount of process water that infiltrated into the shallow alluvial aquifer while the mill was operating could have been approximately 780 million gal or 2400 acre-feet $\left(3.0\right.$ million $\left.\mathrm{m}^{3}\right)$.

A more detailed discussion of contaminant sources is in Section 3.6.

\section{$3.2 \quad$ SOURCES OF EXISTING DATA}

Ground water quality sampling has been performed at the Grand Junction site since the mid-1970s (DOE, 1995c; Cahn et al., 1988). The 1995 water sampling and analysis plan for the Grand Junction site (DOE, 1995c) summarizes much of these data. More detailed information on the site ground water regime is in the RAP (DOE, 1991). The BLRA (DOE, 1995b) evaluates the potential impacts to human health and the environment. Regional studies by the U.S. Bureau of Reclamation (USBR) and the U.S. Geological Survey (USGS) characterize ground water quality in the alluvial materials in the Grand Valley (USBR, 1978; 1986; Butler et al., 1994).

Most of the monitor wells installed historically at the site were decommissioned during surface remedial action. There are 16 monitor wells presently available for sampling in the site vicinity (Figure 3.3). These include 12 alluvial wells, 3 Mancos Shale wells, and 1 Dakota Sandstone well. This total includes 3 alluvial/Mancos Shale well clusters, which are designated: 744/743, 742/741, and 736/735. A summary of construction information and sampling history for all site wells is presented in Table 3.1. All available lithologic logs, well 


\section{Figure 3.3}

\section{Locations of Existing and Decommissioned Monitor Wells} Grand Junction, Colorado, Site Vicinity

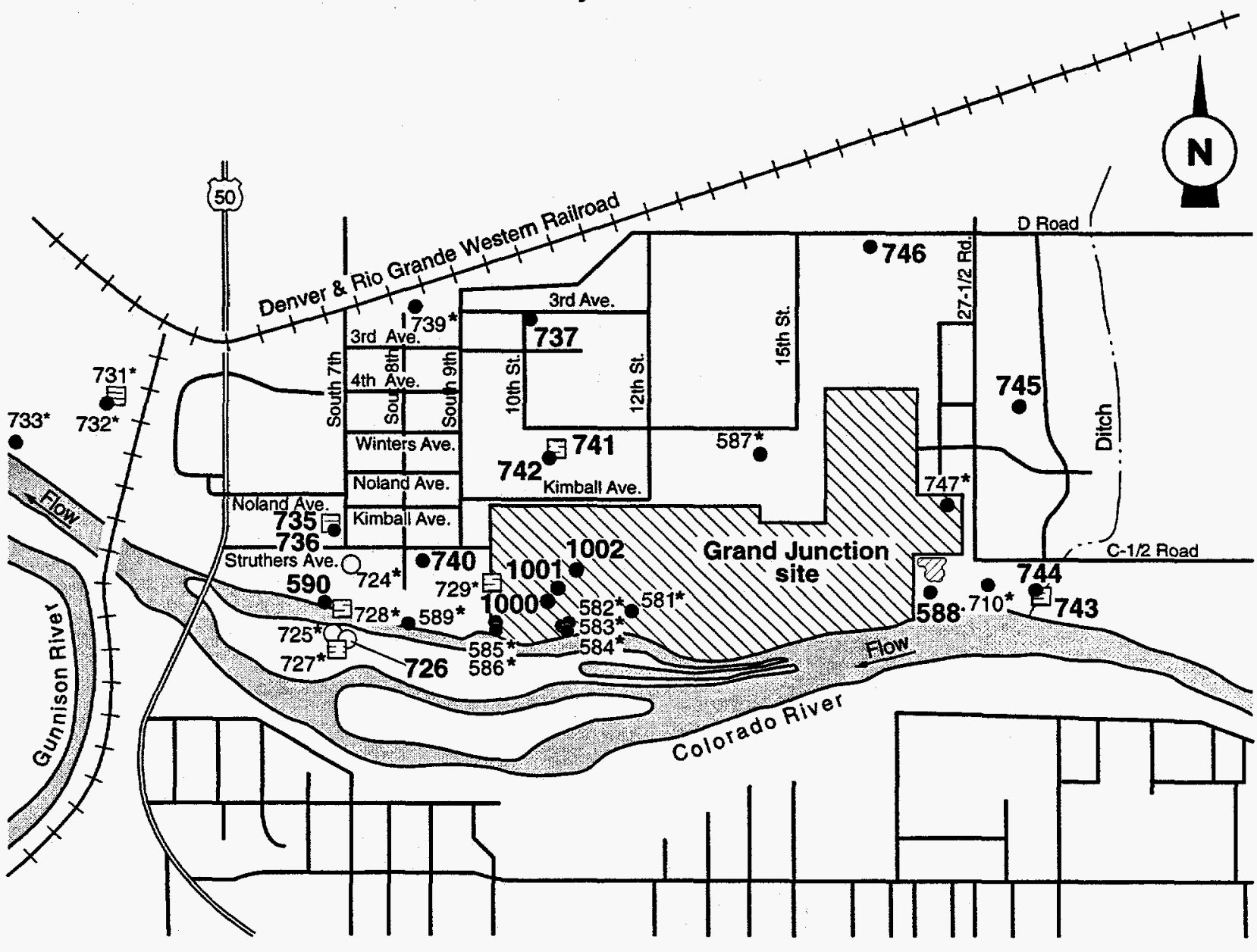

Source: DOE, 1995b.

Notes: 1. Existing monitor wells are labeled in bold type.

\section{Legend}

\begin{tabular}{|cl|}
\hline 740 & $\begin{array}{l}\text { Alluvial monitor well } \\
\text { (12 existing) }\end{array}$ \\
E 731 & $\begin{array}{l}\text { Mancos Shale Formation } \\
\text { monitor well (3 existing) }\end{array}$ \\
724 & $\begin{array}{l}\text { Dakota Sandstone monitor well } \\
\text { (1 existing) } \\
\text { Pond }\end{array}$ \\
50 & U.S. highway
\end{tabular}

2. Decommissioned monitor wells are indicated by an asterisk.

3. On-site ponds are not shown.

4. Alluvial/Mancos Shale Formation well clusters:

- 736, 735

- 742,741

- 744,743 
Table 3.1 DOE ground water monitor well completion and historical sampling data for the Grand Junction, Colorado, site

\begin{tabular}{|c|c|c|c|c|c|c|}
\hline Well ID & $\begin{array}{l}\text { Unit/formation } \\
\text { screened }\end{array}$ & Location & $\begin{array}{c}\text { Screened } \\
\text { interval } \\
\text { (ft bls) }\end{array}$ & Year sampled & $\begin{array}{l}\text { Decommis- } \\
\text { sioned }\end{array}$ & $\begin{array}{l}\text { Number of } \\
\text { sampling } \\
\text { rounds }\end{array}$ \\
\hline GRJ-01-0581 & Oal & On-site & $27-31$ & 89 & $x$ & 1 \\
\hline GRJ-01-0582 & MS & On-site & $36-43$ & 89 & $x$ & 1 \\
\hline GRJ-01-0583 & Qal & On-site & $29-32$ & 83,85 & $x$ & 6 \\
\hline GRJ-01-0584 & Qal & On-site & $23-26$ & 83,85 & $x$ & 6 \\
\hline GRJ-01-0585 & Oal & On-site & $12-14$ & 89 & $x$ & 1 \\
\hline GRJ-01-0586 & Qal & On-site & $6-9$ & 89 & $x$ & 1 \\
\hline GRJ-01-0587 & Qal & Crossgradient & $8-13$ & 83 & $x$ & 3 \\
\hline GRJ-01-0588 & Qal & Background & $8-18$ & $89,91,92$ & & 9 \\
\hline GRJ-01-0589 & Qal & Downgradient & $7-15$ & $89,91,92$ & $x$ & 7 \\
\hline GRJ-01-0590 & Qal & Downgradient & $7-15$ & $83-95$ & $x$ & 17 \\
\hline GRJ-01-0710 & Qal & Background & $?$ & 89 & & 1 \\
\hline GRJ-01-0724 & DS & Upgradient & $131-141$ & $86-89$ & $x$ & 6 \\
\hline GRJ-01-0725 & DS & Upgradient & $69-99$ & 86,89 & $x$ & 3 \\
\hline GRJ-01-0726 & DS & Upgradient & $110-140$ & $86,89,90$ & & 3 \\
\hline GRJ-01-0727 & MS & Upgradient & $44-54$ & 87 & $x$ & 1 \\
\hline GRJ-01-0728 & MS & Downgradient & $12-17$ & 85 & $x$ & 3 \\
\hline GRJ-01-0729 & MS & On-site & $53-63$ & 89 & $x$ & 1 \\
\hline GRJ-01-0731 & MS & Downgradient & $26-36$ & 85 & $x$ & 3 \\
\hline GRJ-01-0732 & Qal & Downgradient & $16-21$ & 85 & $x$ & 3 \\
\hline GRJ-01-0733 & Qal & Downgradient & $16-21$ & $86,88,89$ & $x$ & 5 \\
\hline GRJ-01-0735 & MS & Downgradient & $26-36$ & 89 & & 2 \\
\hline GRJ-01-0736A & Qal & Downgradient & $10-15$ & $85-95$ & & 14 \\
\hline GRJ-01-0737 & Qal & Crossgradient & $22-27$ & $87,88,89$ & & 4 \\
\hline GRJ-01-0739 & Qal & Crossgradient & $25-30$ & 85 & $x$ & 3 \\
\hline GRJ-01-0740 & Qal & Downgradient & $12-17$ & $85-95$ & & 13 \\
\hline GRJ-01-0741 & MS & Crossgradient & & $\begin{array}{c}86,87,88,89 \\
91,92,93\end{array}$ & & 13 \\
\hline GRJ-01-0742 & Oal & Crossgradient & $18-23$ & $85-95$ & & 12 \\
\hline
\end{tabular}


Table 3.1 DOE ground water monitor well completion and historical sampling data for the Grand Junction, Colorado, site (Concluded)

\begin{tabular}{|c|c|c|c|c|c|c|}
\hline Well ID & $\begin{array}{l}\text { Unit/formation } \\
\text { screened }\end{array}$ & Location & $\begin{array}{c}\text { Screened } \\
\text { interval } \\
\text { (ft bls) }\end{array}$ & Year sampled & $\begin{array}{l}\text { Decommis- } \\
\text { sioned }\end{array}$ & $\begin{array}{c}\text { Number of } \\
\text { sampling } \\
\text { rounds }\end{array}$ \\
\hline GRJ-01-0743 & MS & Upgradient & $25-35$ & $\begin{array}{c}86,89,91,92 \\
93\end{array}$ & & 12 \\
\hline GRJ-01-0744 & Qal & Upgradient & $10-15$ & $89,91,92$ & & 10 \\
\hline GRJ-01-0745 & Qal & Background & $15-20$ & $85-95$ & & 16 \\
\hline GRJ-01-0746 & Oal & Background & $20-25$ & $85-95$ & & 16 \\
\hline GRJ-01-1000 & Qal & On-site & $4-9$ & 95 & & 2 \\
\hline GRJ-01-1001 & Qal & On-site & $6.5-11.5$ & 95 & & 2 \\
\hline GRJ-01-1002 & Qal & On-site & $8-13$ & 95 & & 2 \\
\hline
\end{tabular}

ft bls - feet below land surface.

DS - Dakota Sandstone.

MS - Mancos Shale.

Qal - Quaternary alluvium.

? - Unknown.

completion records, and well construction information for existing and decommissioned wells at the site are provided in Appendix A.

Subsets of the existing and decommissioned wells have been sampled historically. Section 5.0 of this SOWP outlines the future data requirements for this site. A qualitative ecological survey that included visual observations of plants and wildlife was also conducted in the vicinity of the site in conjunction with the BLRA. No plant or animal tissue samples were collected or analyzed during this survey.

\subsection{CONCEPTUAL SITE MODEL}

The DOE has reviewed available ground water characterization data identified in Section 3.2 for the site and surrounding area and developed the following conceptual site model. The data are discussed in more detail in Sections 3.4 through 3.8.

The near-surface geology of the Grand Junction site consists of Quaternary alluvium and fill materials. These unconsolidated deposits reach a thickness of about $20 \mathrm{ft}(6 \mathrm{~m})$ beneath the site. Ground water occurs under unconfined conditions in the alluvium and generally flows southwest, toward the Colorado River, although the ground water flows west-southwest immediately west of the site at times of peak river flow. The underlying Mancos Shale Formation, which varies in thickness from more than $100 \mathrm{ft}(30 \mathrm{~m})$ near the site to nearly absent west of the site, acts as an aquitard restricting vertical flow between the alluvium and deeper units. Based on the current understanding of the regional 
hydrologic regime, it is likely that there is an upward vertical hydraulic potential from deeper hydrostratigraphic units, such as the Dakota Sandstone and the Mancos Shale, to the alluvium. Thus, it is unlikely that contamination from the site could have migrated to geologic units underlying the alluvium at the site.

The alluvium in the Grand Junction area consists of three recognizable units. A distinct unit exists closer to the river that includes unconsolidated sands, gravels, and cobbles; this cobble aquifer was noted by USBR (1986). This unit is overlain by and interfingers with a complex interbedding of clay, silt, sand, and gravel derived primarily from the Mancos Shale (hereafter called clayey alluvium). The clayey alluvium in turn grades westward into a colluvium derived from the Mancos Shale. The cobble aquifer underlying the site is recharged by water infiltrating the Mancos Shale-derived clayey alluvium and colluvium upgradient of the site.

The major sources of recharge to the alluvial aquifer are from seasonal runoff, precipitation, and seepage from local irrigation canals and ditches. Areas of the site immediately adjacent to the Colorado River also receive recharge from the river during high river stage. Ground water levels in the alluvial aquifer range from approximately $20 \mathrm{ft}(6 \mathrm{~m})$ to less than $4 \mathrm{ft}(1.3 \mathrm{~m})$ below land surface in areas closest to the Colorado River, based on water level measurements from on-site monitor wells and piezometers. Ground water levels beneath the site fluctuate on the average from 2 to $5 \mathrm{ft}(0.6$ to $1.5 \mathrm{~m})$ annually and are lowest during the fall and winter months. The irrigation season is from April through November, and high river stage occurs in mid- to late-June.

Throughout the Grand Valley, water quality from the unconsolidated alluvial aquifer, including the cobble aquifer, is very poor due to very high TDS. While the Mancos Shale is not considered a source of good-quality ground water in the Grand Valley, its geochemical composition and close relationship to the alluvial ground water flow system (i.e., it underlies the alluvial aquifer system in the Grand Valley) have naturally degraded the alluvial ground water quality with high dissolved mineral salt concentrations. Moreover, the Mancos Shale has been shown to contain naturally high concentrations of several constituents, including uranium, selenium, thorium, and potassium. Based on the ground water hydrogeology and site-specific ground water geochemistry, it is evident that the Mancos Shale is the most likely source of naturally occurring high concentrations of dissolved salts and radionuclides in the shallow alluvial ground water system, including the cobble aquifer, in this area.

Because the water quality in the alluvium is poor, agriculture in the Grand Junction area has long relied on a series of irrigation canals to supply water for crops. This, in turn, has required the installation of a complex series of drainage ditches to dissipate high ground water levels caused by seepage from unlined irrigation canals. Seepage from irrigation canals has also resulted in transport of large amounts of soluble salts to the Colorado River. In an effort to mitigate this problem and improve the quality of water in the river, the USBR is currently in the process of lining major irrigation canals in the Grand Junction area. 
A study by the USGS (Butler et al., 1994) indicates that water quality in the clayey alluvium upgradient of the Government Highline Canal is generally in excess of $10,000 \mathrm{mg} / \mathrm{L}$ TDS. High TDS in these ground waters is due to dissolution of salts associated with the Mancos Shale in the area.

Downgradient of the Government Highline Canal, the clayey alluvium is recharged primarily by seepage from the unlined canal. This results in TDS concentrations in ground water between 3000 to $7000 \mathrm{mg} / \mathrm{L}$ directly downgradient of the canal. Further downgradient, TDS tends to increase and many samples in excess of $10,000 \mathrm{mg} / \mathrm{L}$ are observed. Lining the Government Highline Canal presumably will result in lowering the ground water table in the Grand Junction area and a return to higher TDS water (greater than 10,000 $\mathrm{mg} / \mathrm{L}$ ) that likely was present in the area before the beginning of irrigation.

The USGS study (Butler et al., 1994) provides regional information from a series of wells in the Grand Valley alluvium. This information indicates that many constituents of regional ground water are commonly above UMTRA Project MCLs. For example, uranium concentrations of up to $0.45 \mathrm{mg} / \mathrm{L}$ have been observed and concentrations between 0.04 and $0.07 \mathrm{mg} / \mathrm{L}$ are common. The UMTRA MCL for uranium is $0.044 \mathrm{mg} / \mathrm{L}$. Selenium concentrations as high as $1.3 \mathrm{mg} / \mathrm{L}$ have been observed in the clayey alluvium. This value is 2 orders of magnitude above the UMTRA MCL of $0.01 \mathrm{mg} / \mathrm{L}$.

These observations make it possible to characterize natural ground water quality in the alluvial aquifer in the Grand Junction area as poor and likely to get worse. TDS currently exceeds the 40 CFR Part 192 definition for limited-use ground water $(10,000 \mathrm{mg} / \mathrm{L})$ at many locations in the Grand Valley alluvium, and all ground water in the alluvium likely will increase in TDS after the Government Highline Canal is lined. Uranium and selenium concentrations are currently naturally high in alluvial ground water. Concentrations of these constituents also are likely to increase when the Government Highline Canal lining project is complete.

It is necessary to rely on regional background ground water quality to assess the extent of contamination at the site because upgradient ground water in the site vicinity has the potential to have been impacted by the large number of vicinity properties in the Grand Junction area. Tailings from the UMTRA Project site were once used as construction fill for projects throughout the Grand Junction area, and while most of these vicinity properties have been identified and remediated, upgradient ground water may have received some contamination when water tables in the area rose to near the ground surface. Water quality in upgradient DOE monitor wells, however, falls within the range of regional background water quality.

Tailings leachate migrated into the alluvial aquifer beneath the site and contaminants subsequently migrated downgradient from the site. It is known that the extent of contamination is approximately $3000 \mathrm{ft}(900 \mathrm{~m})$ west of the site. Much of the ground water contamination from the eastern middle third of the site may have either discharged to the Colorado River or migrated west- 
southwest in the alluvial aquifer. Remaining contamination that migrates past the present monitor well network eventually will discharge to the Colorado River. Current data indicate that there has been no measurable impact on the river by site-related contamination. There is currently no known use of ground water crossgradient or downgradient of the site in the area impacted by uranium processing activities.

There is currently no route for contaminated ground water to impact surface water other than the Colorado River. The DOE constructed a series of eight ponds along the southern site boundary in 1994. However, these ponds were destroyed during high river stage in early summer 1995. Construction of ponds in the riverside park downgradient (west) from the site has been proposed by developers. If constructed, these ponds should be monitored to determine any site-related impacts.

\subsection{PHYSICAL SETTING AND GEOLOGY}

The Grand Junction site is in Sections 23 and 24, Township 1 South, Range 1 West, Sixth Principal Meridian, at latitude $39^{\circ} 03^{\prime} 30^{\prime \prime} \mathrm{N}$, longitude $108^{\circ} 34^{\prime} 00^{\prime \prime}$ $W$. The site is approximately $4600 \mathrm{ft}(1400 \mathrm{~m})$ above sea level. The site is situated in the Grand Valley, a broad, semiarid valley cut by the Colorado River and bounded by the Book Cliffs escarpment to the north, the Grand Mesa to the east, and the Uncompahgre Plateau to the south. The Colorado River and one of its tributaries, the Gunnison River, drain the Grand Valley. The confluence of these rivers is approximately $1 \mathrm{mi}(1.6 \mathrm{~km})$ west of the site and the Colorado River continues westward and eventually southwestward around the Uncompahgre Plateau.

The generalized stratigraphy near the site comprises three hydrogeologic zones (in descending order):

- A surficial disturbed zone.

- A zone of unconsolidated alluvial sediments.

- A sequence of consolidated sedimentary formations.

The surficial disturbed zone includes a variety of soil classifications and material types deposited or altered during surface remediation. The zone varies in depth from approximately $1 \mathrm{ft}(0.3 \mathrm{~m})$ to more than $20 \mathrm{ft}(6 \mathrm{~m})$.

Underlying or adjacent to the surficial disturbed zone is a zone of unconsolidated alluvial sediments. In the site vicinity, this zone includes mixed gravel, sand, silt, and clay layers, ranging in thickness from $12 \mathrm{ft}(3.7 \mathrm{~m})$ to $27 \mathrm{ft}(8.3 \mathrm{~m})$. The base of the alluvium is defined by the erosional surface of the Mancos Shale Formation, which slopes gently (about $5 \mathrm{ft} / \mathrm{mi}[1 \mathrm{~m} / \mathrm{km}]$ ) to the west in the immediate vicinity of the site (USBR, n.d.). The top several feet of the Mancos Shale are heavily weathered and contain abundant gypsum and calcite in joints and bedding planes. Figure 3.4 is an isopach map showing the thickness of the 


\section{Figure 3.4}

\section{Isopach Map of the Fill/Alluvium}

Grand Junction, Colorado, Site Vicinity

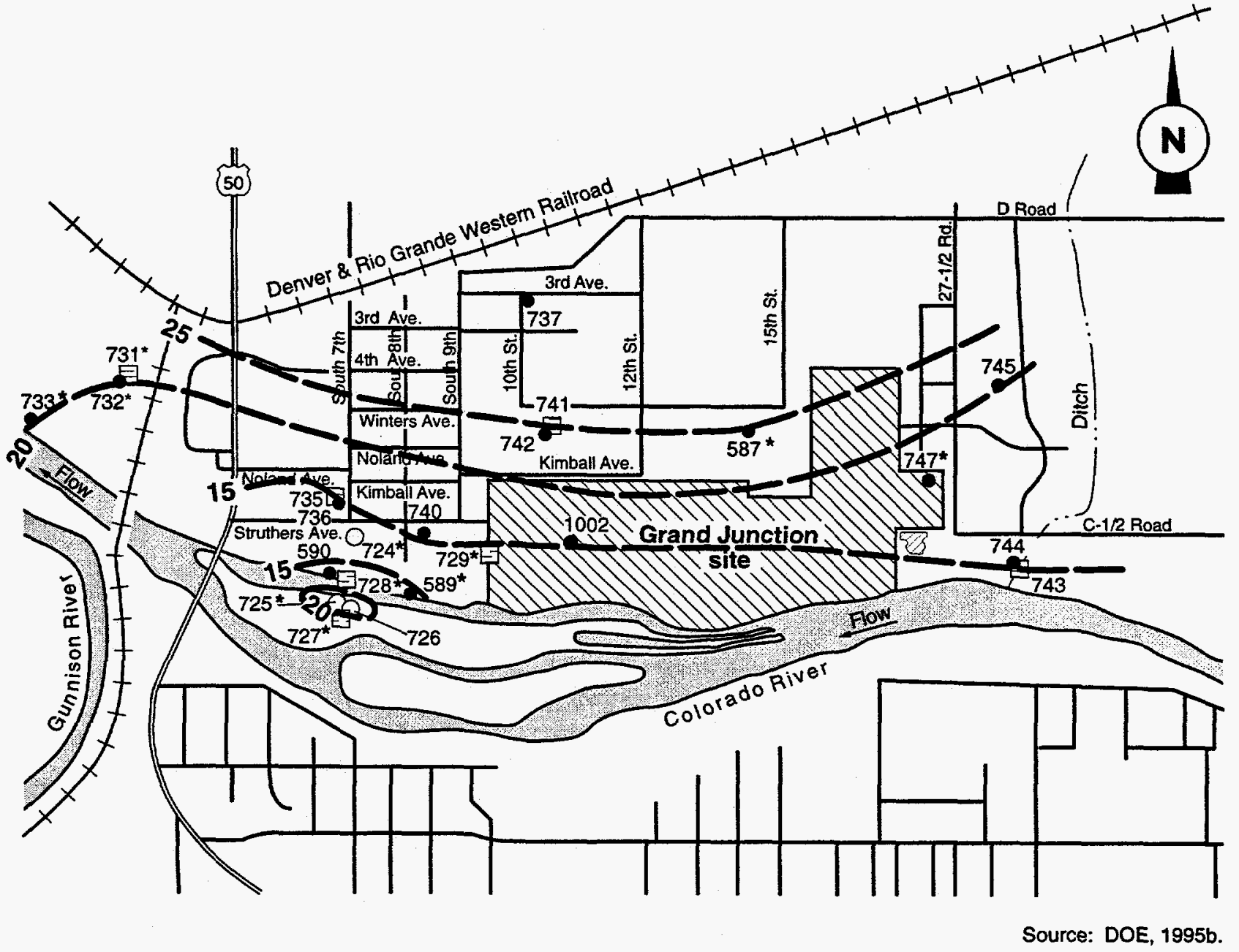

\begin{tabular}{|c|c|}
\hline \multicolumn{2}{|c|}{$\begin{array}{c}\text { Monitor Wells and } \\
\text { of Fill/All }\end{array}$} \\
\hline 590 & 15 \\
\hline 724 & 13 \\
\hline 725 & 21 \\
\hline 726 & 22 \\
\hline 727 & 16.5 \\
\hline 728 & 16 \\
\hline 729 & 12.5 \\
\hline 731 & 19 \\
\hline 732 & 20 \\
\hline 733 & 21 \\
\hline
\end{tabular}

Thicknesses (ft)
\begin{tabular}{|l|l|}
\hline 735 & 13 \\
\hline 736 & 15 \\
\hline 737 & 27 \\
\hline 740 & 16 \\
\hline 741 & 25 \\
\hline 742 & 22.5 \\
\hline 743 & 15 \\
\hline 744 & 14.5 \\
\hline 745 & 20 \\
\hline 747 & 16.5 \\
\hline
\end{tabular}

Notes: 1. Decommissioned monitor wells are indicated by an asterisk

2. On-site ponds are not shown.

3. Thickness of fill/alluvium is based on lithologic logs provided in Appendix A.

\begin{tabular}{|cl}
\hline $20-740$ & Alluvial monitor well \\
Inted line of equal thickness (f) \\
731 & $\begin{array}{l}\text { Mancos Shale Formation } \\
\text { monitor well }\end{array}$ \\
874 & Dakota Sandstone monitor well \\
50 & U.S. highway
\end{tabular}

0.25 0 0.5 Mile

MAC: SITE/GRJ/SOWP/FILL-ALLUV

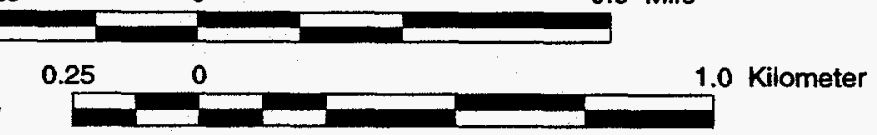


combined fill and alluvium at the site and vicinity. This isopach map illustrates a general thickening of the fill/alluvium toward the north. This general trend results from the sloping erosional surface of the Mancos Shale toward the westnorthwest and the slope of the topographic surface toward the south.

Underlying the unconsolidated alluvial sediments is a sequence of consolidated sedimentary formations (Figure 3.5). This SOWP will focus primarily on the uppermost formations: the Mancos Shale Formation and the Dakota Sandstone Formation. Lohman (1965) and Cahn et al., (1988) describe other deeper formations present beneath the site. This section will not discuss these deeper formations in any detail because the Dakota Sandstone Formation is the uppermost bedrock aquifer and tailings seepage will not likely impact underlying formations. Section 3.5.1 briefly discusses the deeper formations from a regional hydrologic perspective.

Structurally, a series of monoclines are present on the eastern flank of the Uncompahgre Plateau/Uplift. These monoclines are faulted locally along their anticlinal hinges (Heyman, 1983). Most of the Grand Valley north of the Colorado River is underlain by Mancos Shale. A prominent local exposure of the Mancos Shale is clearly visible on the south bank of the Colorado River, just south of the site. As a rule, however, exposed bedrock or subcropping bedrock on the south side of the Colorado River, south of Grand Junction, is composed of the Dakota Sandstone and/or the underlying Burro Canyon Formation. As stated above, all of these bedrock units dip northeastward in the Grand Valley as a result of the Uncompahgre Plateau/Uplift to the south.

The Mancos Shale Formation is a thick, relatively extensive sequence of shale that includes some sandy layers, thin sandstone beds, and thin coals. Near the Grand Junction site, the Mancos Shale varies in thickness from more than $100 \mathrm{ft}(30 \mathrm{~m})$ to nearly absent west of the site. Figure 3.6 is a structure contour map of the top of the Mancos Shale in the vicinity of the site. In general, the top of the Mancos Shale mimics that of the water table and topographic surface in the site vicinity. The Mancos Shale Formation is not considered a water source in the Grand Junction area. Although the upper portion of the Mancos Shale is weathered and capable of conducting ground water, as a whole this unit acts as an aquitard or barrier to vertical flow between the Dakota Sandstone and the alluvial aquifer due to its relatively low hydraulic conductivity. In fact, the Mancos Shale is the unit that produces confined conditions within the Dakota Sandstone beneath the Grand Valley and immediately northeast of the Grand Valley (Lohman, 1965).

The Dakota Sandstone and Burro Canyon Formations form the uppermost bedrock aquifer that underlies the Mancos Shale. The Dakota Sandstone and Burro Canyon Formations consist of beds of sandstone, conglomeritic sandstone, shale, and coal. These units are not considered productive sources of water in the Grand Junction area (Lohman, 1965). Depth to the top of the Dakota Sandstone in the site vicinity ranges from 70 to $170 \mathrm{ft}(20$ to $50 \mathrm{~m})$ 
Figure 3.5

Generalized Geologic Cross Section of the Grand Valley, Colorado

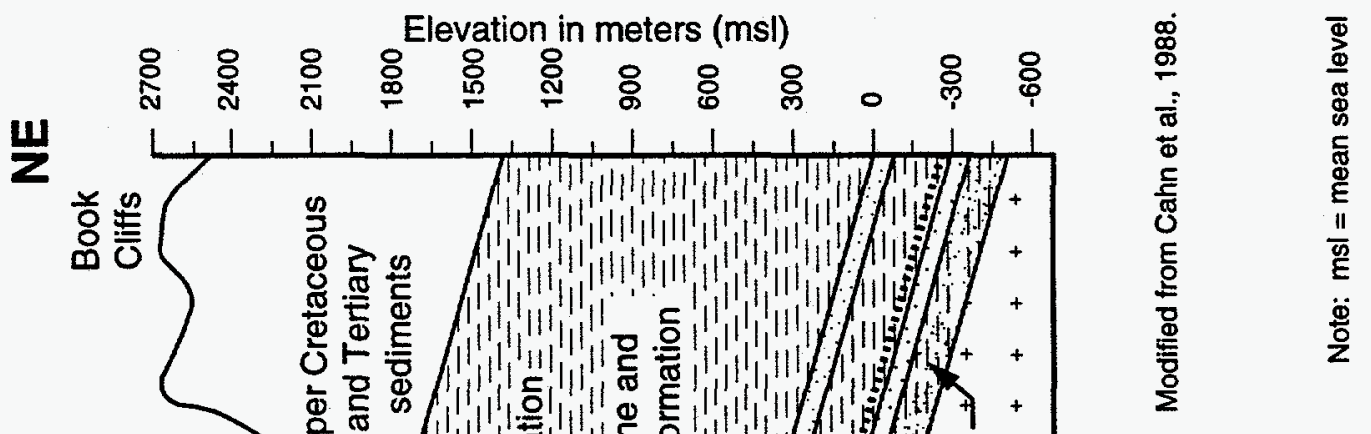

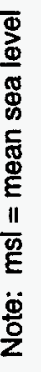

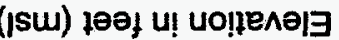

$11-$ Jan-96 RJ) (WCI/L) 


\section{Figure 3.6}

\section{Structure Contour Map of the Top of the Mancos Shale Formation Grand Junction, Colorado, Site Vicinity}

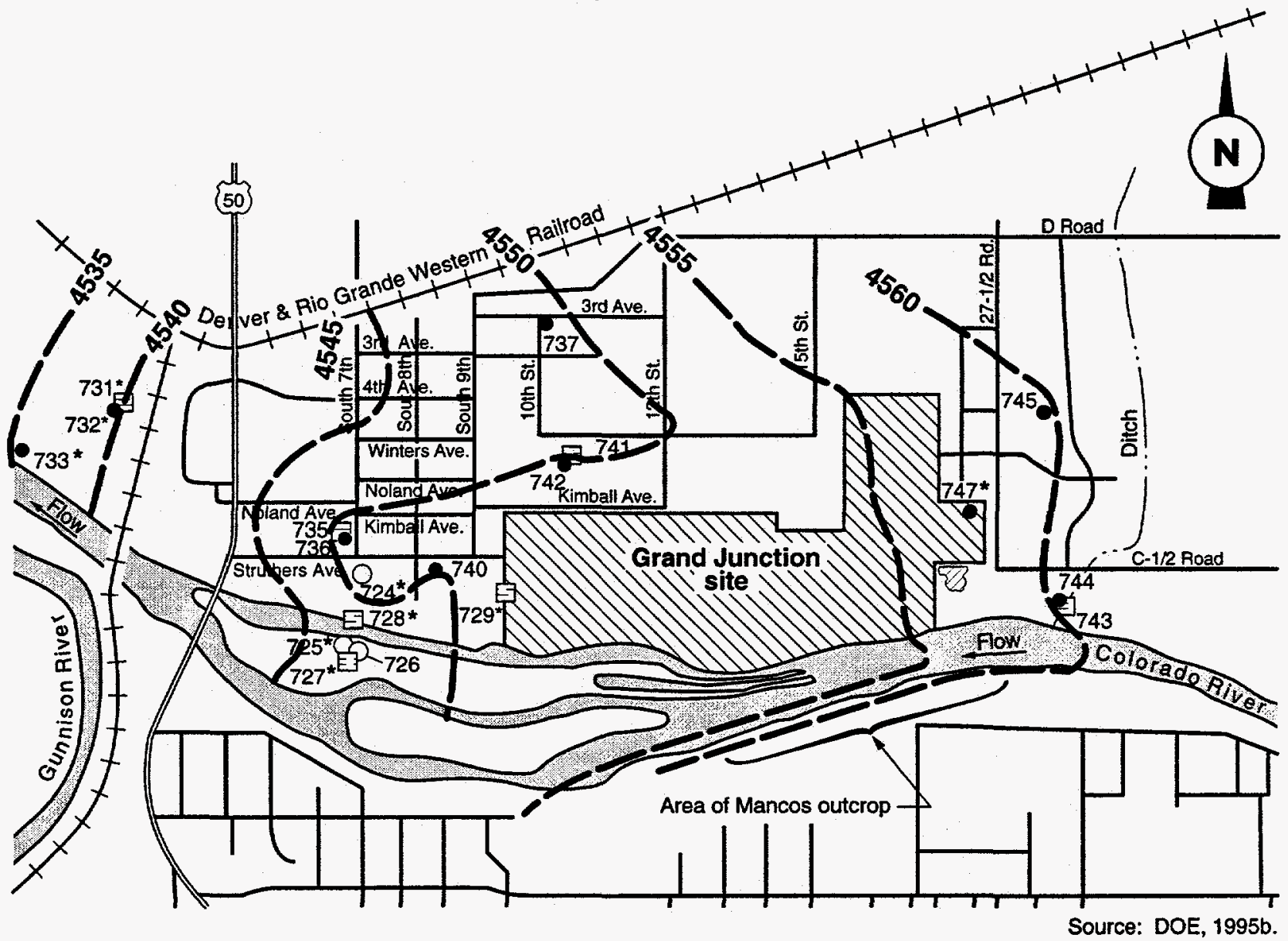

\begin{tabular}{|l|l|}
\hline \multicolumn{2}{|c|}{$\begin{array}{c}\text { Monitor Wells and } \\
\text { Mancos S }\end{array}$} \\
\hline 724 & 4551.7 \\
\hline 725 & 4545.8 \\
\hline 726 & 4544.8 \\
\hline 727 & 4549.9 \\
\hline 728 & 4549.0 \\
\hline 729 & 4552.8 \\
\hline 731 & 4540.7 \\
\hline 732 & 4539.5 \\
\hline 733 & 4535.4 \\
\hline 735 & 4551.7 \\
\hline
\end{tabular}

Notes: 1. Decommissioned monitor wells are indicated by an asterisk.

2. On-site ponds are not shown.

3. Development of data based on lithologic logs provided in Appendix A and well survey data.

\begin{tabular}{|l|l|}
\hline 736 & 4549.7 \\
\hline 737 & 4548.3 \\
\hline 740 & 4550.1 \\
\hline 741 & 4547.9 \\
\hline 742 & 4550.2 \\
\hline 743 & 4560.1 \\
\hline 744 & 4560.3 \\
\hline 745 & 4559.4 \\
\hline 747 & 4557.8 \\
\hline
\end{tabular}

\section{Legend}

Inferred line of equal elevation of top of

${ }_{4545} 45$ Mancos Shale Formation (ft above $\mathrm{msl}$ )

- 740 Alluvial monitor well

ت731 Mancos Shale Formation monitor well

○724 Dakota Sandstone monitor well

83 Pond

(50) U.S. highway

0.25 
below land surface. All bedrock formations beneath the processing site dip to the northeast at approximately 7 degrees (Lohman, 1965).

\subsection{GROUND WATER AND SURFACE WATER HYDROLOGY}

Ground water and surface water hydrology are discussed from both regional and local perspectives to allow a more complete understanding of hydrological issues affecting the site.

\subsubsection{Regional ground water hydrology}

The important aquitards in the Grand Valley are the Morrison Formation and the Mancos Shale, the latter of which is widespread and attains a maximum thickness of $4000 \mathrm{ft}(1200 \mathrm{~m})$ in the Grand Valley. The four confined hydrostratigraphic units in order of importance are the Entrada Sandstone, the Wingate Sandstone, the Salt Wash Member of the Morrison Formation, and the Burro Canyon Formation/Dakota Sandstone (Lohman, 1965; Cahn et al., 1988). While these units are not considered major aqùifers by most standards, they are capable of producing small quantities of reasonably good-quality ground water. In contrast, the Mancos Shale produces meager amounts of highly mineralized water from the unconfined weathered zone. The USBR (1978) indicates that this zone is thin, but in many locations it has a very high hydraulic conductivity. Thus, it is believed to carry water that seeped from the local system of canals and ditches to the Colorado River. Similarly, the Dakota Sandstone produces only small quantities of generally salty water (Lohman, 1965).

The predominant source of recharge to the bedrock aquifers in the Grand Valley is through infiltration at sandstone outcrops/subcrops and faults immediately northeast of the monocline (Lohman, 1965). These bedrock aquifers also are recharged through local precipitation. Since the ground water produced by wells completed in these bedrock hydrogeologic units is either low quantity and/or low quality, the vast majority of water used in the Grand Valley is acquired from surface water sources. The regional ground water flow direction of the confined bedrock aquifer units located within the Grand Valley is to the northeast (Lohman, 1965). This direction is consistent with the dip of these bedrock units. Ground water recharge along outcrops and faults immediately northeast of the Uncomphagre Plateau monocline moves very slowly downdip (e.g., estimated velocity of $5 \mathrm{ft}[1.5 \mathrm{~m}]$ per year) in the Entrada Sandstone. The northeast dip of the Entrada Sandstone extends beyond the Grand Valley, toward the northwest-southeast trending axis of the Piceance Creek basin. Northeast of the Piceance Creek basin axis, ground water in these confined bedrock units flows southwest. Regional movement of the ground water is caused by the structural configuration of these units as well as small losses of head within these units along the flow path through upward leakage due to primary and secondary permeability (Lohman, 1965).

The regional recharge area for the Dakota Sandstone (and all deeper confined aquifer units) is located south of the Grand Junction site. Given that ground 
water migrates under confined conditions in these units with upward leakage, it seems reasonable to conclude that the vertical potentials from the Dakota Sandstone and deeper formations are generally upward. Since the Dakota Sandstone is believed to be confined by the Mancos Shale at the site, an upward hydraulic vertical potential likely exists between the Dakota Sandstone and the Mancos Shale.

In 1955, a test well, located about $2 \mathrm{mi}(3 \mathrm{~km})$ down river from the Grand Junction site, was completed to $61 \mathrm{ft}(18 \mathrm{~m})$ in the Dakota Sandstone (Lohman, 1965). This well flowed at 2.5 gallons $(9.5 \mathrm{~L})$ per minute with a static water level of plus or minus $3 \mathrm{ft}(1 \mathrm{~m})$ above ground surface. The water was salty and contained hydrogen sulfide. In 1960, the well was filled up to a depth of $29 \mathrm{ft}$ $(9 \mathrm{~m})$. This flowing well discharges from the Dakota Sandstone to the Colorado River alluvium (1 to $5 \mathrm{mi}$ [1.6 to $8 \mathrm{~km}$ ] below the site). No recharge is possible to the west since the Dakota Sandstone is truncated. Thus, recharge must come from the southeast. As a result, ground water flow in the Dakota Sandstone is upward near the site and likely has a northeastward component of flow.

The alluvium in the Grand Junction area consists of three recognizable units. A distinct unit closer to the river consists of unconsolidated sands, gravels, and cobbles, and is locally referred to as the cobble aquifer (USBR, 1986) (Figure 3.7) The cobble aquifer is overlain by and interfingers with a complex interbedding of clay, silt, sand, and gravel derived primarily from the Mancos Shale. This clayey alluvium unit grades northward, away from the site (Figure 3.7), into a colluvium consisting of reworked Mancos Shale fragments derived from the underlying Mancos Shale as well as the Mancos Shale highlands (the Book Cliffs) to the North (Cahn et al., 1988; Evangelou et al., 1984). Along the path of the Colorado River, these unconsolidated deposits cover the Mancos shale in a 2- to 3-mi (3- to 5-km)-wide strip from Loma, Colorado, west of the Grand Junction site, to Palisade, Colorado, east of the site. To the north, the alluvium/colluvium unit thins (Figure 3.7), and eventually pinches out in the vicinity of the Government Highline Canal (Figure 3.8). Ground water recharge to the alluvial/colluvial and cobble aquifers, as well as the upper weathered Mancos Shale section, occurs as a result of precipitation, vertical upward flow from the Mancos Shale, and seepage from the Grand Valley canal system. In the vicinity of the Grand Junction site, ground water within the alluvial and cobble aquifer discharges into the Colorado River.

\section{Irrigation canals and ditches in the Grand Valley}

The elevation of the water table in the unconsolidated alluvium and the quality of water in this aquifer is influenced by irrigation practices in the Grand Valley. The first irrigation ditch systems were built in the early 1880 s. There are currently over $180 \mathrm{mi}(300 \mathrm{~km})$ of major unlined irrigation canals built across the Grand Valley (Figure 3.8). Drainage canals and ditches were constructed by farmers in the Grand Valley to control high water tables from return flows. There are approximately $500 \mathrm{mi}(800 \mathrm{~km})$ of lateral ditches and drainage 
Figure 3.7

Generalized Hydrogeologic Cross Section of the Uppermost Formations Within the Grand Valley, Colorado

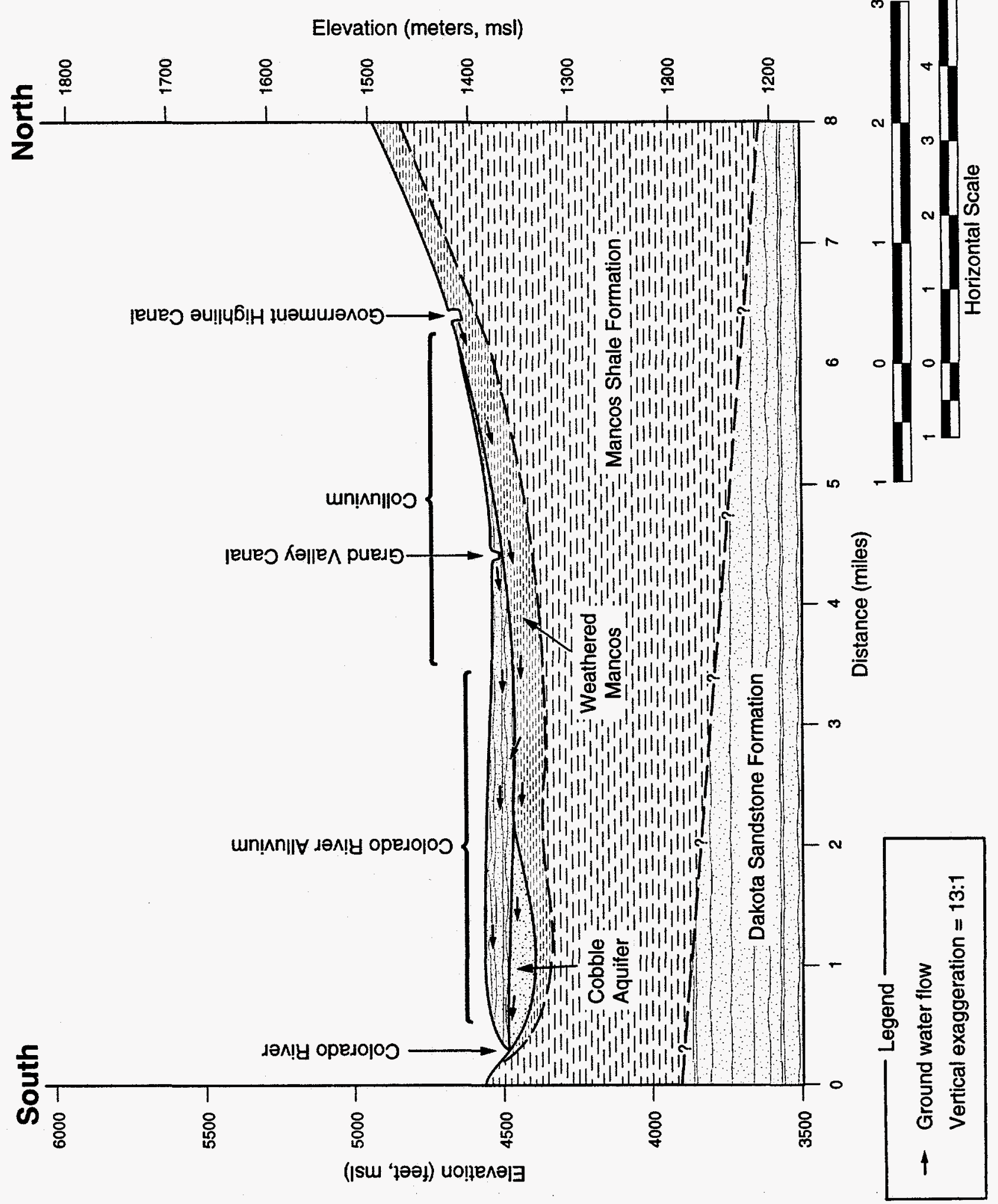

MAC: STEGGRUSOWPIGENHYDPO 


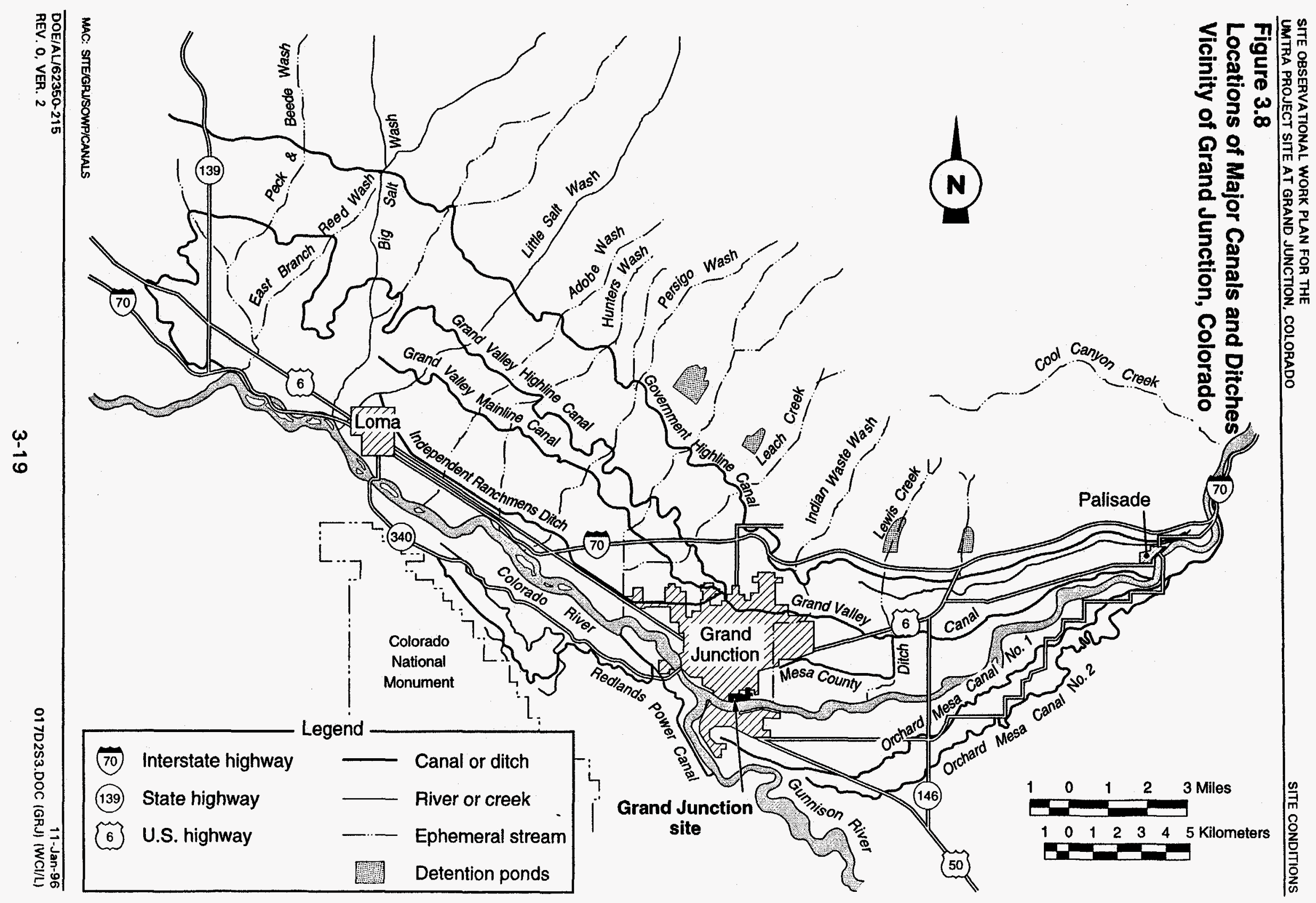


ditches, 35 outlets to the Colorado River, and 9 outlets to dry washes in the Grand Valley. Some of these ditches and portions of canals were constructed or repaired using tailings during the uranium boom in the 1950s (USBR, 1986; Cahn et al., 1988).

The irrigation canals are typically filled with Colorado River water from April through November each year. Seepage infiltrates into the alluvial and cobble aquifer and accumulates high concentrations of dissolved minerals from the weathered Mancos Shale, which is located at or near the surface of most of the Grand Valley. Poor drainage conditions, high water tables, and high evaporation rates have resulted in soil and subsoil accumulations of salt, alkali, or both, which adversely affect a portion of the available agricultural acreage in the Grand Valley (USBR, 1978). Mineralized waters from the Mancos Shale, where present, also infiltrate into the alluvial aquifer system, including the cobble aquifer (Cahn et al., 1988). The USBR has instituted a salinity control program for the Grand Valley, designed to reduce highly saline irrigation return to the Colorado River and to reduce the seepage moving through saline strata, such as the Mancos Shale (USBR, 1978; 1986). Seepage is reduced by lining the canals or placing the flow in pipes. This program is designed to reduce salt loading in the Colorado River in the Grand Valley by approximately 410,000 tons 1372,000 metric tons) annually. Recent studies of ground water quality in the vicinity of the canal systems in the Grand Valley illustrate that salt loadings to the Colorado River have been reduced (Butler et al., 1994). The effect of lining the canals is to cut off the major source of recharge to the alluvial aquifer, leaving only the Mancos Shale colluvium to recharge the alluvial and cobble aquifers. This will result in locally lower water tables and a gradual degradation in water quality in this aquifer.

\subsubsection{Local ground water hydrology}

This section discusses ground water hydrogeologic data from the site and adjacent areas. The alluvium is the uppermost aquifer in the Grand Junction site vicinity. Based on water level measurements from on-site monitor wells and piezometers, the depth to ground water in the alluvium ranges from approximately $10 \mathrm{ft}(3 \mathrm{~m})$ in areas away from the Colorado River to less than $4 \mathrm{ft}(1 \mathrm{~m})$ in areas closest to the river. Water levels collected from the site and vicinity (Figure 3.9) document that alluvial ground water flows southwest toward the site. However, the alluvial ground water has a more pronounced westward flow direction at the western portion of the site. Figure 3.9 illustrates these two distinct ground water flow directions as a large diverging ground water flow direction arrow. The reason for such a divergence of alluvial ground water flow is most likely related to the stage of the Colorado River, the changing direction of the Colorado River toward the west-northwest, and perhaps the influence of the downstream confluence of the Colorado and Gunnison Rivers and discharge of ground water from the Dakota Sandstone. A smaller southwesterly-oriented alluvial ground water flow direction arrow is shown on Figure 3.9 beneath the eastern half of the site. 
Figure 3.9

Water Table Contour Map (Alluvial Aquifer), February 28 through March 7, 1989 Grand Junction, Colorado, Site Vicinity
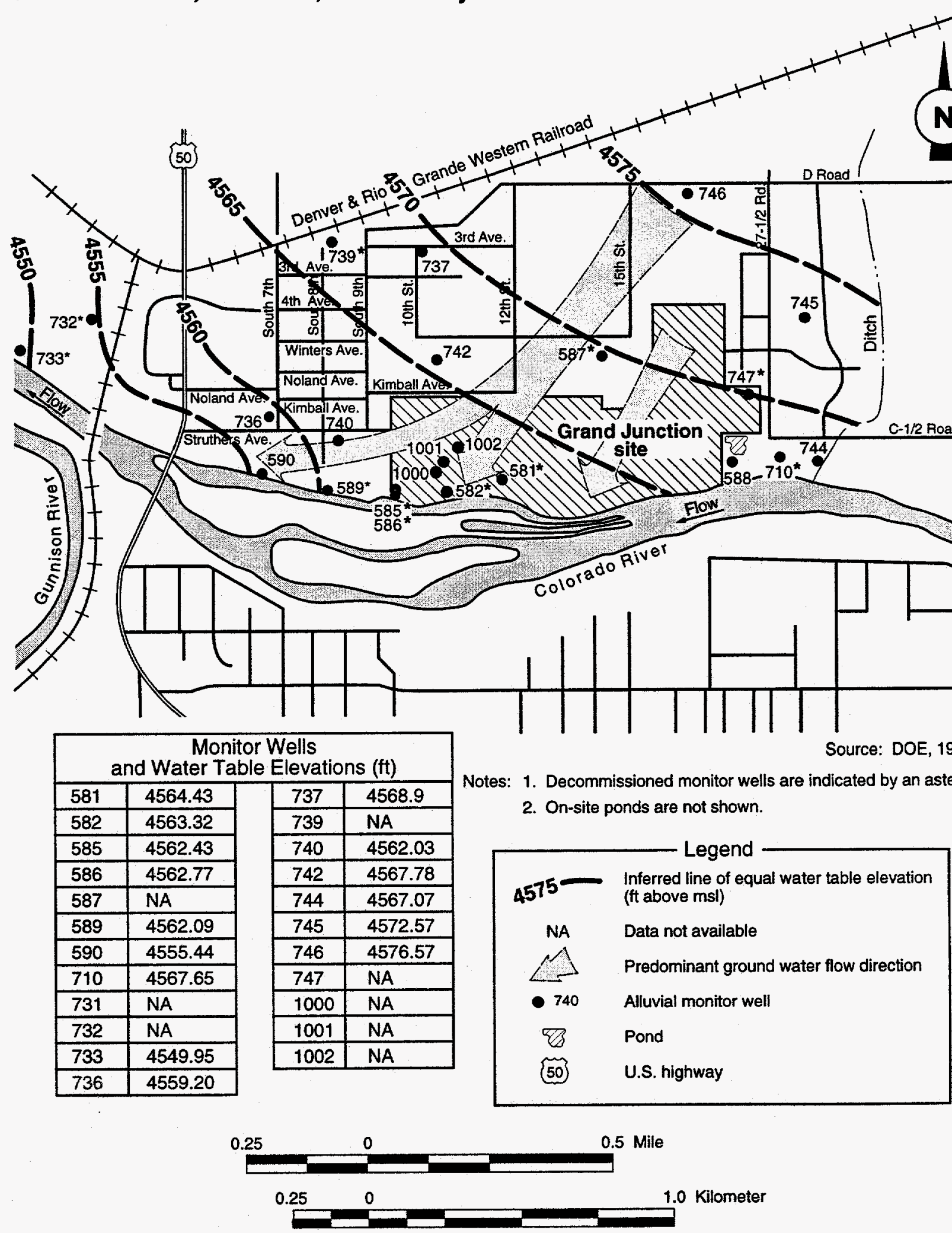

MAC: SITE/GRJ/SOWPIWATRTABL 
This ground water flow information indicates that ground water beneath the eastern two-thirds of the Grand Junction site discharges in a southwesterly direction to the Colorado River, while ground water beneath the western third of the site migrates in the alluvial aquifer in a west-southwest direction. Although data are sparse in this area, it is likely that the majority of alluvial ground water beneath the western third of the site discharges to the Colorado River before it reaches the railroad track that crosses the Colorado River on the west side of U.S. Highway 50 (U.S. 50) (Figure 3.9). Although discussed in more detail in Section 3.5, these generalizations regarding alluvial ground water flow directions are consistent with our understanding of ground water quality impacts at the site and vicinity.

Ground water levels in the alluvial aquifer beneath the site fluctuate 2 to $5 \mathrm{ft}$ $(0.6$ to $1.5 \mathrm{~m})$ annually and are lowest during fall and winter. These fluctuations occur due to changes in river stage, precipitation, local irrigation, and upgradient recharge. Water level data from new on-site wells 1000, 1001, and 1002 and off-site well 746 (continuously monitored) are collected and assessed quarterly.

Regionally, the Mancos Shale Formation is a low-permeability formation that is not water-bearing or that transmits only limited quantities of water (Cooley et al., 1969; Lohman, 1965). Although saturated beneath the Grand Junction site, as a whole, the Mancos Shale acts as an aquitard inhibiting vertical flow between the Dakota Sandstone and the alluvial aquifer due to its relatively low hydraulic conductivity. Structurally, the Mancos Shale has been deformed by the monoclines illustrated in Figure 3.5. Visual descriptions from the lithologic logs provided in Appendix A document weathered to highly weathered shale in monitor wells 594, 711, 719, 720, 721, 724, 725, 727, 729, 730, 731, 735 . 741, and 742. (Note: Many of these monitor wells have been decommissioned and their locations are not provided on figures in this report.) Sandstone seams were noted in borings 725 and 727 , and fractures causing losses in circulation during drilling were noted in boring 725 . Fractures in the Dakota Sandstone and Mancos Shale at borings 725 and 727 are likely trending northwest, parallel to the monocline's strike. These fractures, acting as localized vertical discharge points, may be causing the apparent westerly component of flow in the alluvial aquifer. During the advancement of boring 735, "artesian flow" was observed at $40 \mathrm{ft}(12 \mathrm{~m})$ (just $25 \mathrm{ft}[7.6 \mathrm{ml}$ below the top of the Mancos Shale) and the initial "large flow reduced to trickle after 10 minutes." These observations demonstrate that secondary permeability due to fracturing may be pronounced in the Mancos Shale beneath the site. Based on understanding of the monoclinal deformation that has occurred, it can be surmised that fracturing associated with this deformation has some vertical component. However, the current continuity of these fractures is unknown due to the self-healing nature of a unit such as the Mancos Shale with its high clay and silt content.

Furthermore, from a regional hydrogeologic basin perspective, it is likely that vertical heads between the sedimentary bedrock units and the unconsolidated alluvium are upward in the vicinity of the site (see Section 3.5.1). Therefore, even if the combined primary and secondary permeabilities of the Mancos Shale 
are capable of conducting appreciable ground water in the vertical direction, this upward vertical potential would preclude the migration of affected ground water from the alluvium to deeper units.

While the Mancos Shale is not considered a viable aquifer, its geochemical composition and close relationship to the alluvial ground water flow system have naturally degraded the alluvial ground water quality with high dissolved mineral salt concentrations (Evangelou et al., 1984). Moreover, the Mancos Shale has been shown to contain naturally high concentrations of uranium, thorium, and potassium (Pliler and Adams, 1962). Based on the ground water hydrogeology and site-specific ground water geochemistry (discussed in Section 3.5), it is evident that the Mancos Shale is the most likely source of naturally occurring high concentrations of dissolved salts and radionuclides in the shallow alluvial ground water system in this area.

Ground water flow directions in the Dakota Sandstone were not determined due to a lack of borings into the unit. Ground water flow in the Dakota Sandstone is very likely to the northwest. The Dakota Sandstone does have an upward potential for flow into the Mancos Shale or other overlying formations in the site vicinity (Lohman, 1965).

Figure 3.10 shows the locations of hydrogeologic cross sections $A-A^{\prime}$ and $B-B^{\prime}$. Cross section A-A' (Figure 3.11) is oriented to generally coincide with the ground water flow direction along a path that crosses the western third of the site. Cross section B-B' (Figure 3.12 ) is oriented roughly perpendicular to the predominant ground water flow direction and also crosses the western third of the site. These cross sections show the variability of the alluvial lithology across the site. In general, the basal alluvium consists of coarser, relatively conductive sediments such as sands and gravels compared to the near-surface materials. This pattern is consistent with fluvial reworked sediments expected next to the present channel of the Colorado River.

Cross section B-B' shows that the alluvial materials lying below the water table become finer toward the river. The finer alluvial sediment acting in conjunction with the irregular surface of the upper Mancos Shale may retard basal ground water flow within the alluvium near the river. West and downgradient of the site (cross section $A-A^{\prime}$, well 733 ), the alluvial sediments are more coarse and the Mancos Shale nearly pinches out. Both cross sections indicate that on-site fill placed during surface remediation appears to have little influence on ground water flow as the fill was generally used to replace the shallow (upper $5 \mathrm{ft}$ [1.5 m]) alluvial material.

\section{Hydraulic characteristics}

An average hydraulic conductivity in the alluvium, as determined from aquifer pumping tests (DOE, 1991), is approximately $9.8 \times 10^{-4} \mathrm{ft}$ per second (ft/s) $\left(3 \times 10^{2}\right.$ centimeters per second $\left.[\mathrm{cm} / \mathrm{s}]\right)$. Linear ground water velocity in the 


\section{Figure $\mathbf{3 . 1 0}$}

\section{Hydrogeologic Cross Section Location Map Grand Junction, Colorado, Site Vicinity}

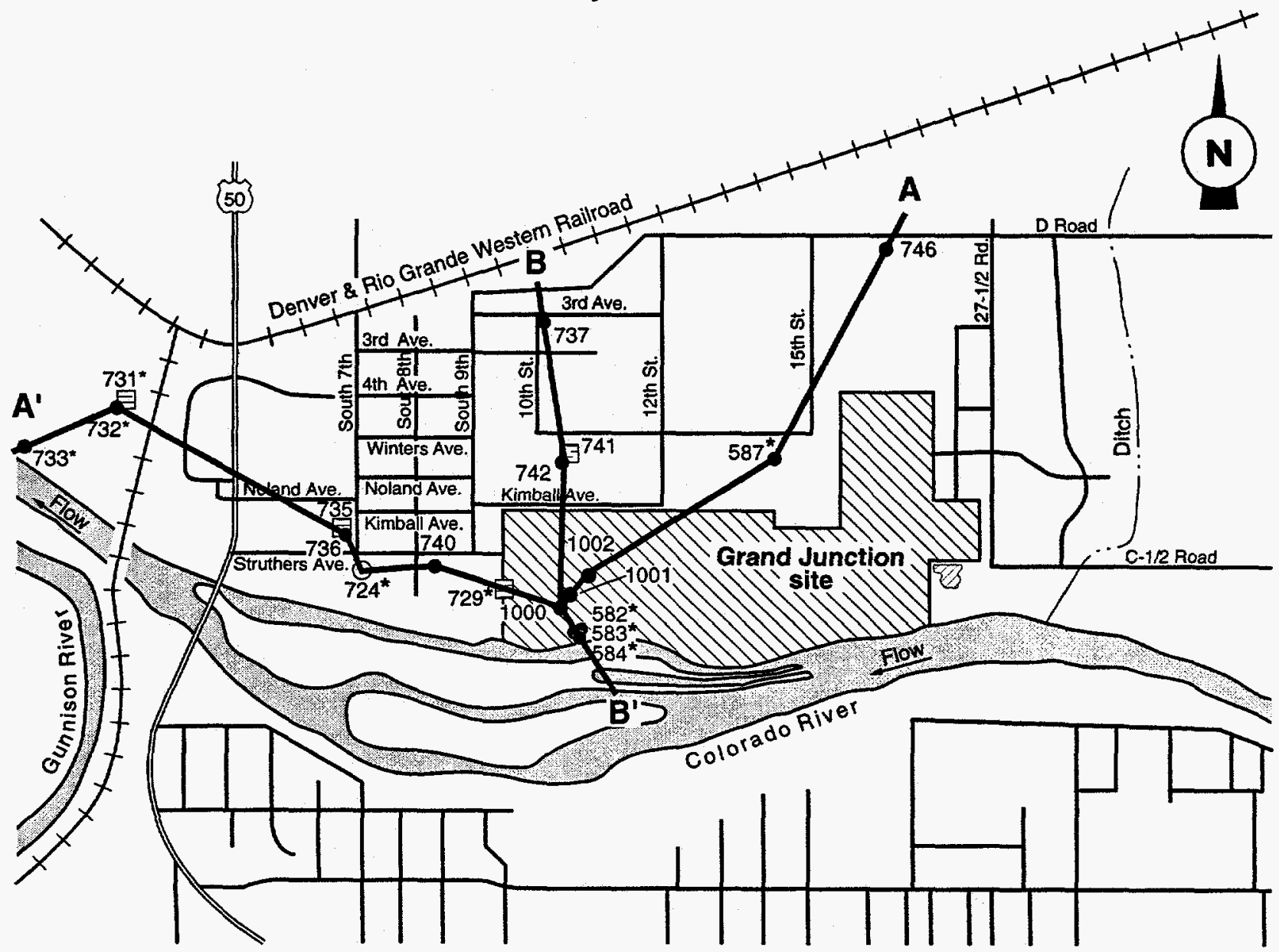

Source: DOE, 1995b.

Notes: 1. Decommissioned monitor wells are indicated by an asterisk.

2. On-site ponds are not shown.

Legend

\begin{tabular}{cl}
740 & Alluvial monitor well \\
\hline 731 & Mancos Shale Formation monitor well \\
724 & Dakota Sandstone monitor well \\
8 & Pond \\
50 & U.S. highway
\end{tabular}

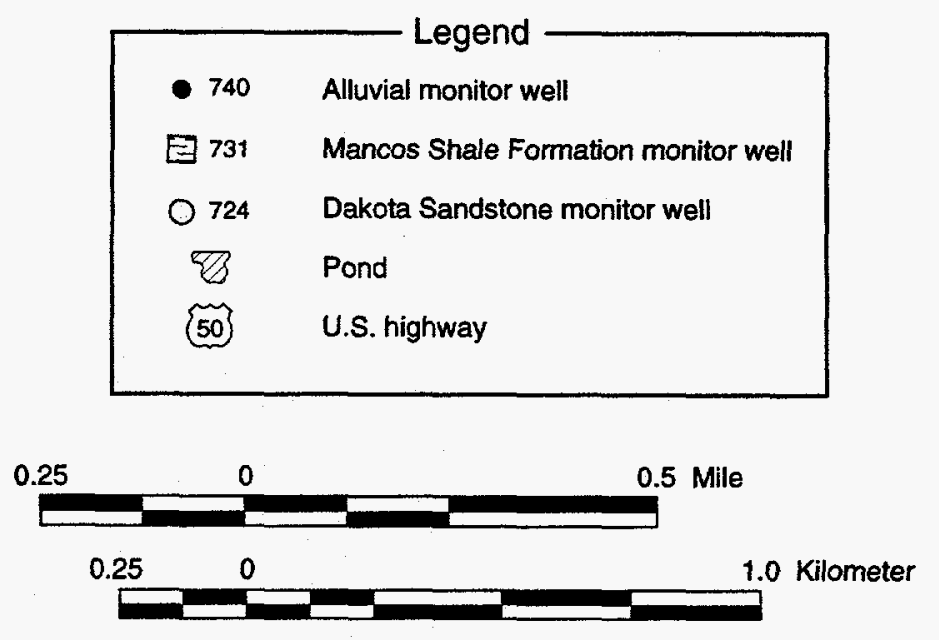

MAC: STTE/GRJ/SOWPROCXSECS 


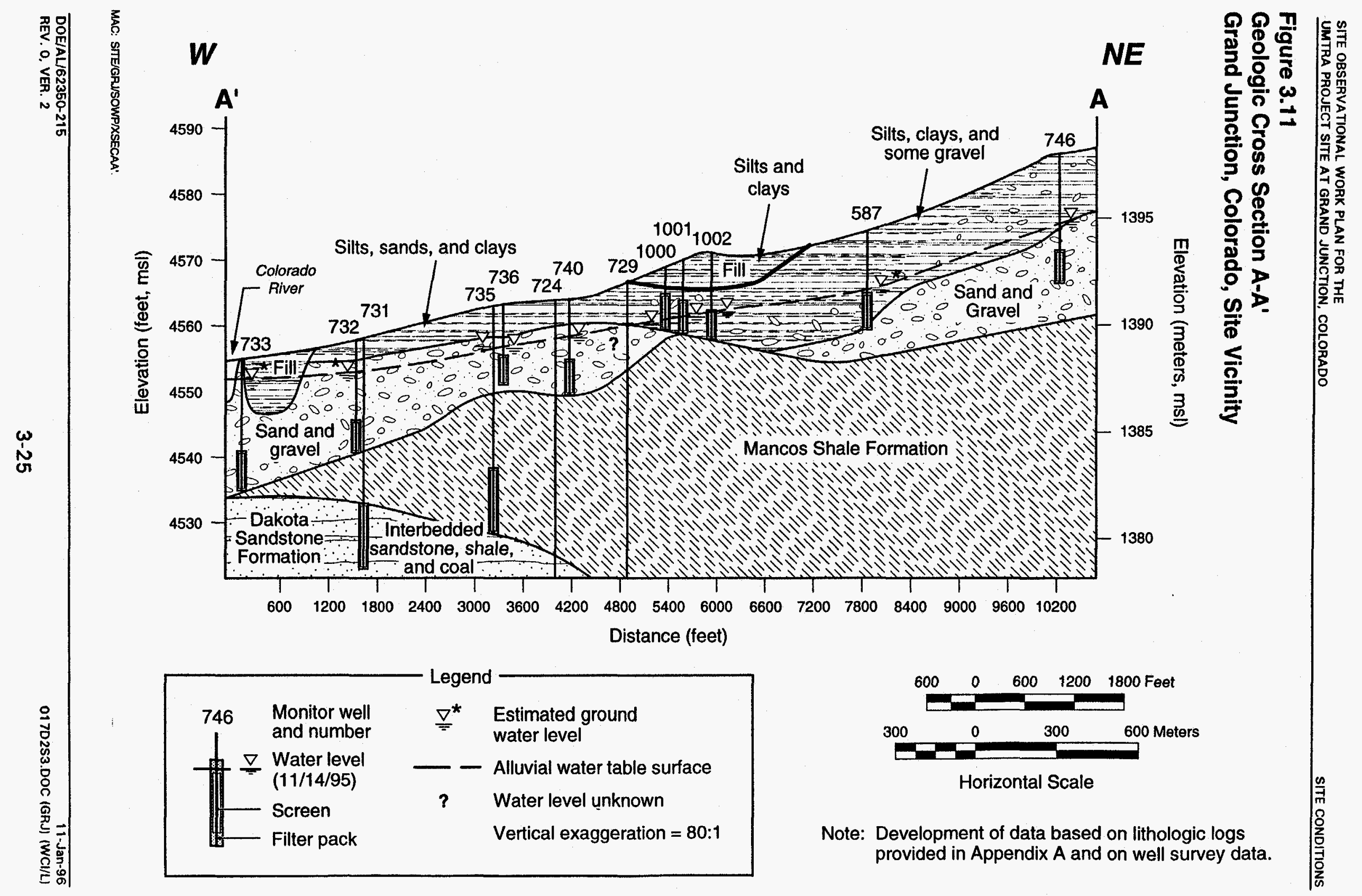




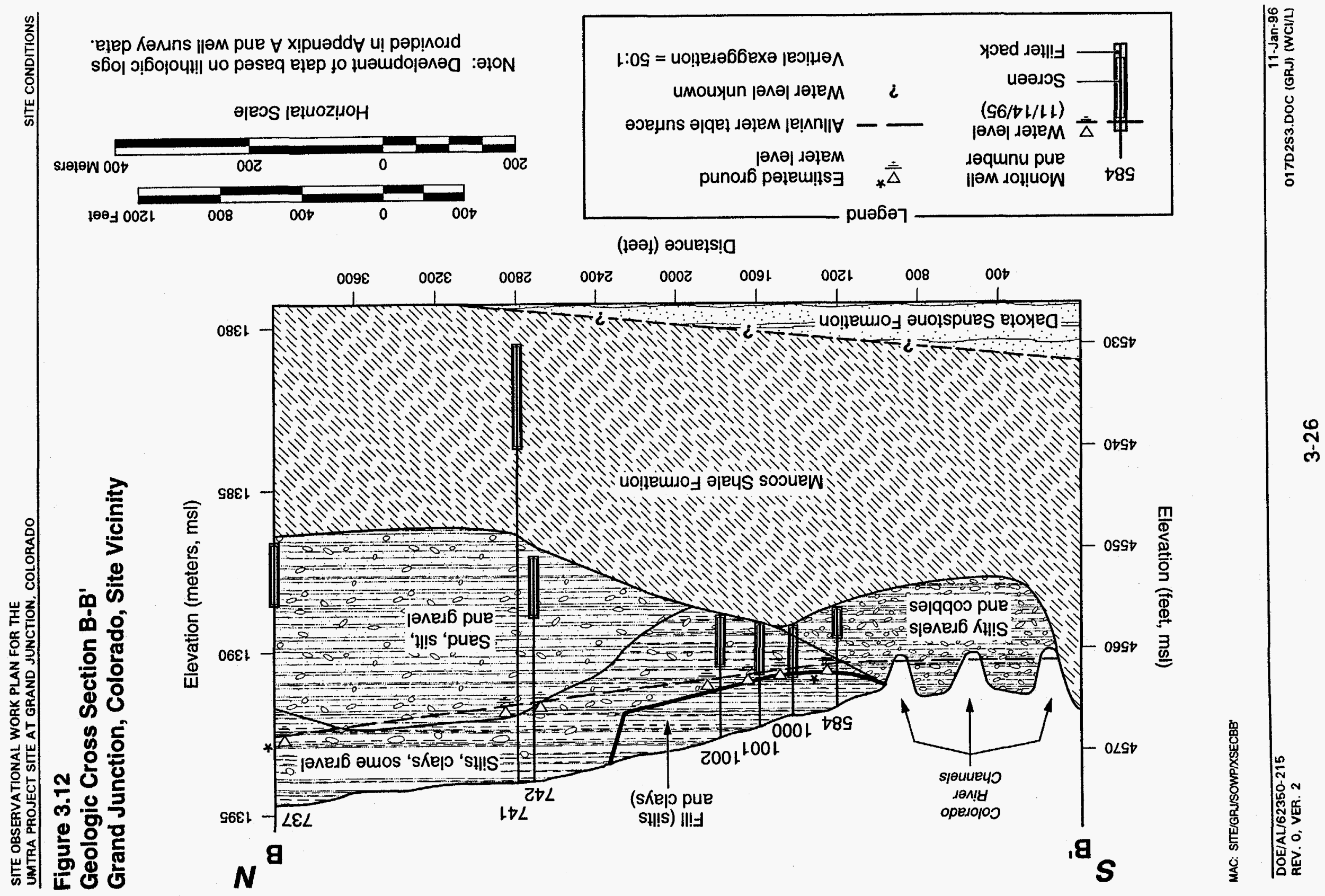


alluvium ranges from 0.2 to $5 \mathrm{ft}$ per day $(0.06$ to $1.5 \mathrm{~m} /$ day), depending on location-specific conditions (DOE, 1991).

The USBR (1978) reports a hydraulic conductivity of $6.9 \times 10^{-3} \mathrm{ft} / \mathrm{s}\left(2.1 \times 10^{-1}\right.$ $\mathrm{cm} / \mathrm{s}$ ) in the weathered Mancos Shale. The DOE (1991) reports that calculated hydraulic conductivities in the unweathered Mancos Shale average $2.09 \times 10^{-7}$ $\mathrm{ft} / \mathrm{s}\left(6.4 \times 10^{-6} \mathrm{~cm} / \mathrm{s}\right)$. The horizontal hydraulic conductivity of the unweathered shale is presumed to decrease with increasing depth.

Table 3.2 summarizes hydraulic conductivity data for the Dakota Sandstone and Mancos Shale from the Grand Junction site. Depending upon the source of these data, the Mancos Shale hydraulic conductivity ranges from values similar to that of the Dakota Sandstone to roughly 1 order of magnitude lower than that of the Dakota Sandstone (Table 3.2). While this relationship makes sense, the validity of these actual values is unknown.

Table 3.3 summarizes the historic relative vertical potentials of existing ground water well clusters $742 / 741,744 / 743$, and $736 / 735$ completed in the alluvium and Mancos Shale. These vertical-potential data, collected from 1985 through 1993, show both upward and downward relative vertical potentials.

Unfortunately, the completion intervals between wells in well cluster 742/741 and well cluster 744/743 are only separated by a few feet (Appendix A). Well cluster $736 / 735$ is a little better for evaluating vertical hydraulic potentials with a completion interval separation of approximately $10 \mathrm{ft}(3 \mathrm{~m})$. However, given that the upper weathered portion of the Mancos Shale is known to have adequate secondary permeability to conduct some ground water, these minimal completion interval separations make these data minimally useful for the purposes of developing meaningful conclusions, based on localized data, regarding the vertical potentials between these units. However, as previously discussed in the section regarding regional ground water flow systems, an upward vertical potential is most likely present under the Grand Junction site.

It has been assumed that all data in Table 3.3 represent static head. However, this is not always a reasonable assumption for wells completed in lowpermeability formations such as the Mancos Shale. It is known from experience on other sites that wells completed in low-permeability shale formations may take months or even longer to recover to static levels following purging associated with sampling. This, coupled with seasonal water level fluctuations, results in the collection of water level data that may be below that of true static for the unit. Of the three well clusters presented in Table 3.3, this bias may be most likely in well cluster $736 / 735$.

\subsubsection{Surface water-ground water interactions}

The northern channel of the Colorado River forms the southern boundary of the Grand Junction site (Figure 3.3). A Mancos Shale Formation outcrop forms the southern bank of the Colorado River south of the site. Several large sandbars in the river south and southwest of the site cause the river to flow into separate 
Table 3.2 Slug withdrawal test results in the Mancos Shale and Dakota Sandstone at the Grand Junction, Colorado, site

\begin{tabular}{|c|c|c|c|}
\hline \multirow{2}{*}{$\begin{array}{c}\text { Well ID } \\
\text { (Unit of Completion) }\end{array}$} & \multicolumn{3}{|c|}{ Hydraulic conductivity ${ }^{a}$ by method } \\
\hline & C-B-P $\mathrm{P}^{\mathrm{b}}$ & $F-K^{c}$ & Skibitzke $^{d}$ \\
\hline GRJ-01-0724 (DS) & NA & NA & $4.6 \times 10^{-5}$ \\
\hline \multirow[t]{2}{*}{ GRJ-01-0725 (DS) } & $2.6 \times 10^{-5}$ & $7.9 \times 10^{-6}$ & NA \\
\hline & $4.4 \times 10^{-5}$ & & \\
\hline GRJ-01-0727 (MS) & $5.5 \times 10^{-6}$ & $7.3 \times 10^{-7}$ & $7.7 \times 10^{-7}$ \\
\hline GRJ-01-0729 (MS) & NA & NA & $1.9 \times 10^{-7}$ \\
\hline GRJ-01-0731 (MS) & NA & NA & $9.4 \times 10^{-7}$ \\
\hline GRJ-01-0735 (MS) & NA & NA & $3.9 \times 10^{-7}$ \\
\hline GRJ-01-0741 (MS) & $5.8 \times 10^{-5}$ & $1.4 \times 10^{-5}$ & $2.4 \times 10^{-5}$ \\
\hline GRJ-01-0743 (MS) & $4.9 \times 10^{-4}$ & $1.4 \times 10^{-6}$ & NA \\
\hline
\end{tabular}

${ }^{a}$ Expressed as centimeters per second converted from transmissivity by assuming effective thickness of aquifer equal to saturated gravel pack.

${ }^{b}$ Cooper-Bredegoeft-Papadopulus (Lohman, 1972)

'Ferris and Knowles (1963).

'Skibitzke (1963).

Table modified from Table 3.4 in Grand Junction RAP (DOE, 1991).

Unit of completion: DS = Dakota Sandstone; $M S=$ Mancos Shale.

$\mathrm{NA}=$ not available. 
Table 3.3 Water level elevations and relative vertical potentials of ground water well clusters at the Grand Junction,

Colorado, site

\begin{tabular}{|c|c|c|c|c|c|c|c|c|c|c|c|c|c|}
\hline Well cluster & & & & & & Dates sam & pled and w & vater level $e$ & elevations & & & & \\
\hline $\begin{array}{l}\text { Date } \\
\text { GRJ-01-0742 }\end{array}$ & $\begin{array}{c}5 / 5 / 85 \\
4567.47\end{array}$ & $\begin{array}{l}5 / 17 / 85 \\
4567.45\end{array}$ & $\begin{array}{l}7 / 10 / 85 \\
4566.96\end{array}$ & $\begin{array}{l}7 / 23 / 86 \\
4567.28\end{array}$ & $\begin{array}{c}3 / 3 / 89 \\
4567.78\end{array}$ & $\begin{array}{l}1 / 26 / 91 \\
4566.78\end{array}$ & $\begin{array}{l}8 / 28 / 91 \\
4566.02\end{array}$ & $\begin{array}{r}11 / 19 / 91 \\
4566.63\end{array}$ & $\begin{array}{l}2 / 21 / 92 \\
4566.68\end{array}$ & $\begin{array}{c}10 / 9 / 92 \\
4565.9\end{array}$ & $\begin{array}{c}2 / 3 / 93 \\
4566.68\end{array}$ & $\begin{array}{l}6 / 27 / 93 \\
4566.77\end{array}$ & $\begin{array}{l}12 / 7 / 93 \\
4566.29\end{array}$ \\
\hline GRJ-01-0741 ${ }^{\circ}$ & 4567.12 & 4567.01 & 4566.60 & 4566.95 & 4568.33 & 4567.84 & 4566.19 & 4566.84 & $4566.0 s$ & 4565.8 & 4566.69 & 4566.75 & 4567.11 \\
\hline $\begin{array}{l}\text { Vertical } \\
\text { potential }\end{array}$ & Down & Down & Down & Down & Up & Up & Up & Up & Down & Down & Up & Down & Up \\
\hline
\end{tabular}

potential

Well cluster $\quad$ Dates sampled and water level elevations"

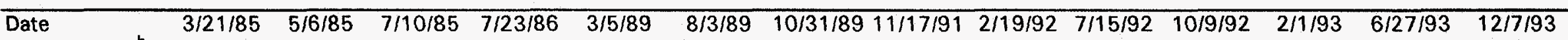

$\begin{array}{lllllllllllllll}\text { GRJ-01-0744 } & 4567.65 & 4572.02 & 4568.68 & 4568.68 & 4567.07 & 4567.13 & 4566.78 & 4567.23 & 4566.92 & 4567.0 & 4566.73 & 4567.12 & 4570.18 & 4567.21\end{array}$

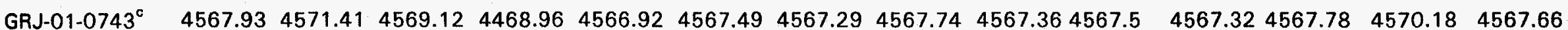

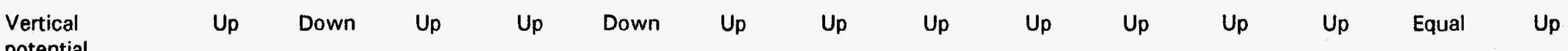

potential

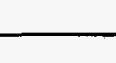

Well cluster

Dates sampled and water level elevations"

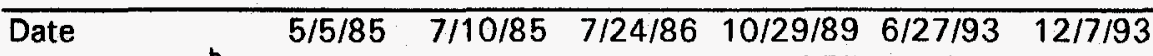

$\begin{array}{lllllll}\text { GRJ-01-0736 }^{\mathrm{b}} \quad \mathbf{4 5 5 9 . 0 5} & \mathbf{4 5 5 9 . 1 2} & \mathbf{4 5 5 8 . 7 5} & \mathbf{4 5 5 7 . 5 5} & \mathbf{4 5 5 9 . 1 2} & \mathbf{4 5 5 8 . 4 1}\end{array}$

$\begin{array}{lllllll}\text { GRJ-01-0735 } & 4537.20 & 4547.15 & 4559.28 & 4533.75 & 4558.50 & 4558.44\end{array}$

Vertical Down Down Up Down Down Up

potential

"Water level elevations in feet above mean sea level.

'Completed in Quaternary alluvium.

'Completed in Mancos Shale. 
channels during much of the year. The Gunnison River flows into the Colorado River about $1.5 \mathrm{mi}(2.5 \mathrm{~km})$ west of the site. As previously stated, the Colorado River most likely is the ultimate discharge point for most and likely all of the ground water contamination migrating from the site.

The stages of the Colorado River fluctuate seasonally, with high stage usually occurring in June and low stage occurring in February. A staff gauge installed in the Colorado River at the U.S. 50 overpass in late 1994 is used to periodically monitor river stage fluctuations. The lower curve on Figure 3.13 shows the estimated surface water hydrograph for the period October 1994 through September 1995. The hydrograph indicates that river stage at the U.S. 50 staff gauge rose more than $7 \mathrm{ft}(2 \mathrm{~m})$ during early June 1995 and returned to near low-flow stage by early September.

From a historical perspective, the 1995 water year was somewhat unique in that peak flow statistics from the Colorado River at the closest USGS upstream gauging station (Cameo, near Debeque, Colorado) and the closest USGS downstream gauging station (near the Colorado-Utah state line) indicate that the 10-year high was exceeded or nearly exceeded (USGS, 1995). This makes the 1995 peak flow the highest since the initiation of systematic ground water data collection at the Grand Junction site in 1984.

Ground water levels beneath the site generally fluctuate 2 to $5 \mathrm{ft}(0.6$ to $1.5 \mathrm{~m})$ annually and are lowest during fall and winter. These fluctuations occur primarily due to changes in river stage but also may occur to a lesser extent due to irrigation and upgradient recharge. Although on-site and vicinity shallow ground water levels may also be influenced slightly due to precipitation, it is expected to be a minor contributor.

Continuous water level data from on-site wells 1001 and 1002 and off-site well 746 are collected and assessed quarterly. In September 1994, wells 1001, 1002 , and 746 were installed and equipped with data loggers set to record ground water levels at 4-hour intervals. In assessing the relative elevations of the curves, it should be noted that well 746 is located upslope from wells 1001 and 1002 , at a higher elevation.

Figure 3.13 illustrates the ground water level hydrographs for on-site wells 1001 and 1002 (middle curves) and background well 746 (top curve) for the period from October 1994 through September 1995. Wells used to gather continuous water level data were generally aligned from northeast to southwest, approximating the local ground water flow direction. Analysis of the hydrographs for wells 1001 and 1002 indicate that throughout most of the year (during base flow conditions), on-site ground water flow is to the southwest toward the river at an approximate horizontal hydraulic gradient of 0.003 . This gradient agrees closely with the determined hydraulic gradient for the entire site during low-flow conditions. The hydrographs indicate that during periods when the stage of the Colorado River is elevated (from early June through mid-July for 1995), the hydraulic gradient in the vicinity of the river is reversed for a time, 
Figure 3.13

Ground Water and Surface Water Level Hydrographs (10/19/94-9/5/95) Grand Junction, Colorado, Site

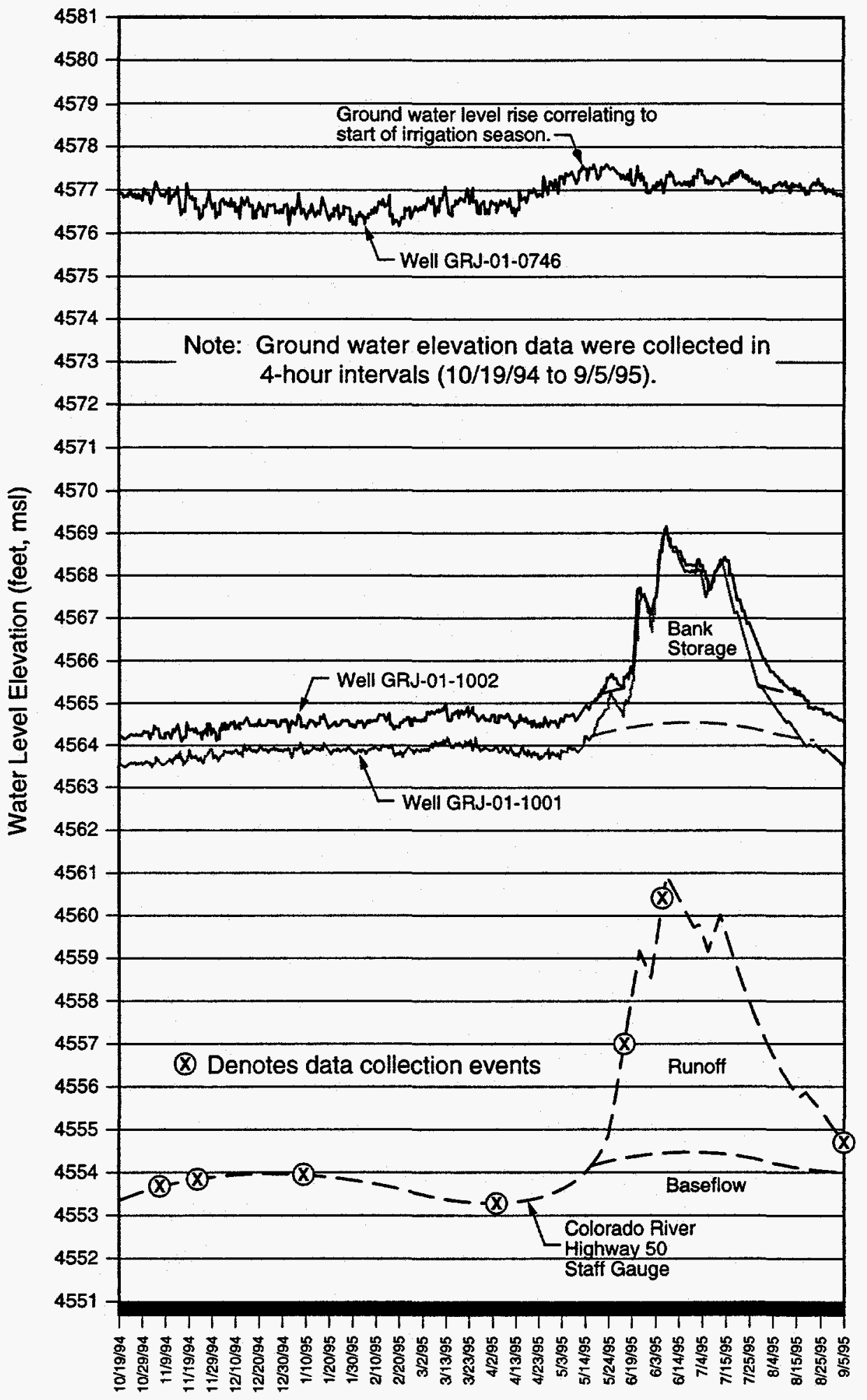


depending on the distance from the river. This represents an annual phenomenon due to mountain snow melt water. During this time period, a component of flow is westward, down the axis of the Colorado River.

With the limited data available, the temporal and areal extent of the river's influence on ground water flow in the alluvium during a given year is not known. However, ground water level responses in wells 1001 and 1002 show that the alluvial aquifer at the site is influenced during high-river flow conditions. In contrast to ground water level responses observed in wells 1001 and 1002, background well 746 showed little, if any, response from fluctuation of the river stage.

In addition to the Colorado River, the canals and drainage ditches discussed in Section 3.5.1 also influence ground water in the site vicinity (Figure 3.8). These canals and ditches, which are used to irrigate and drain land in the site vicinity, have a seasonal influence on local unconfined ground water levels, and they have historically had a major influence on shallow ground water quality. The effects of these canals and ditches on local ground water quality are discussed in depth in the following section.

\subsection{GEOCHEMISTRY}

All available DOE water quality data from the wells shown in Figure 3.3 were used to characterize the plume geometry and the geochemical processes active at the Grand Junction site. This section will identify and discuss the following:

- Background ground water quality in the alluvial aquifer.

- Uranium processing and process solutions.

- The extent and magnitude of contamination of the alluvium by milling-related activities.

- The milling-related contaminants that are of concern to human health and the environment (contaminants of potential concern).

- The fate and transport characteristics of the contaminants of potential concern.

\subsubsection{Background ground water quality}

Background ground water quality is defined as the quality of ground water that would exist at the site if the milling had not taken place. Under this definition, other sources of ground water contamination (e.g., industrial or domestic sources) that have affected the water quality of the aquifers at this site would be considered part of the upgradient quality. In the past, upgradient DOE monitor wells 745 and 746 have been accepted as the monitor wells that most 
likely sample background ground water (Figure 3.3). However, the possibility that contaminants from tailings-contaminated vicinity properties in Grand Junction have affected the chemistry of the ground water sampled by monitor wells 745 and 746 cannot be ruled out on the basis of the currently available data. Consequently, this section contains a discussion of regional ground water quality data for certain constituents that occur at levels above the UMTRA Project MCLs (Table 1 of 40 CFR Part 192, as amended by 60 FR 2854) in regional ground water in addition to a description of water quality in wells 745 and 746 as an indication of background for the Grand Junction site.

\section{Regional ground water quality}

Throughout the Grand Valley, water quality from the unconsolidated alluvial aquifer, including the cobble aquifer, is very poor due to very high TDS. As stated previously, the Mancos Shale underlies the unconfined alluvial aquifer beneath the Grand Valley. While the Mancos Shale is not considered a source of quality ground water in the Grand Valley, its geochemical composition and close relationship to the alluvial ground water flow system (i.e., it underlies the alluvial aquifer system in the Grand Valley) have naturally degraded the alluvial ground water quality with high dissolved mineral salt concentrations (Evangelou et al., 1984). Moreover, the Mancos Shale has been shown to contain naturally high concentrations of uranium, thorium, and potassium (Pliler and Adams, 1962). Based on the ground water hydrogeology and site-specific ground water geochemistry, it is evident that the Mancos Shale is the most likely source of naturally occurring high concentrations of dissolved salts and radionuclides in the shallow alluvial ground water system, including the cobble aquifer, in this area.

A study by the USGS (Butler et al., 1994) indicates that specific conductance of water in the clayey alluvium upgradient of the Government Highline Canal is generally in the range of 10,000 to 20,000 microsiemens per $\mathrm{cm}(\mathrm{mS} / \mathrm{cm})$ (Figure 3.14). (The factor to approximately convert $\mathrm{mS} / \mathrm{cm}$ conductivity to $\mathrm{mg} / \mathrm{L}$ TDS approaches 1 for these high-TDS, high-sulfate waters [Hem, 1992]; thus. $10,000 \mathrm{mS} / \mathrm{cm}$ is approximately equivalent to $10,000 \mathrm{mg} / \mathrm{L}$ TDS.) High TDS in these ground waters are due to dissolution of salts associated with the Mancos Shale in the area. Calcite, gypsum and gypsum minerals (such as selenite and anhydrite), halite, and in some areas, barite, have been dissolved from unweathered Mancos Shale and redeposited in joints and bedding planes during the weathering process (USBR, 1978). Thus, these soluble minerals have become available to ground water in the clayey alluvium. The result is water quality in all alluvial materials that is dominated by sodium sulfate but also contains high levels of bicarbonate, chloride, magnesium, and calcium (Butler et al., 1994).

Downgradient of the Government Highline Canal, the clayey alluvium is recharged primarily by seepage from the unlined canal. This results in TDS concentrations in ground water between 3000 to $7000 \mathrm{mg} / \mathrm{L}$ directly downgradient of the canal (Figure 3.14) (Butler et al., 1994; USBR, 1978). 


\section{Figure 3.14}

Ranges of Downhole Specific Conductance of Water

From Selected Wells in Grand Valley, June-July 1991

Grand Junction, Colorado, Site Vicinity

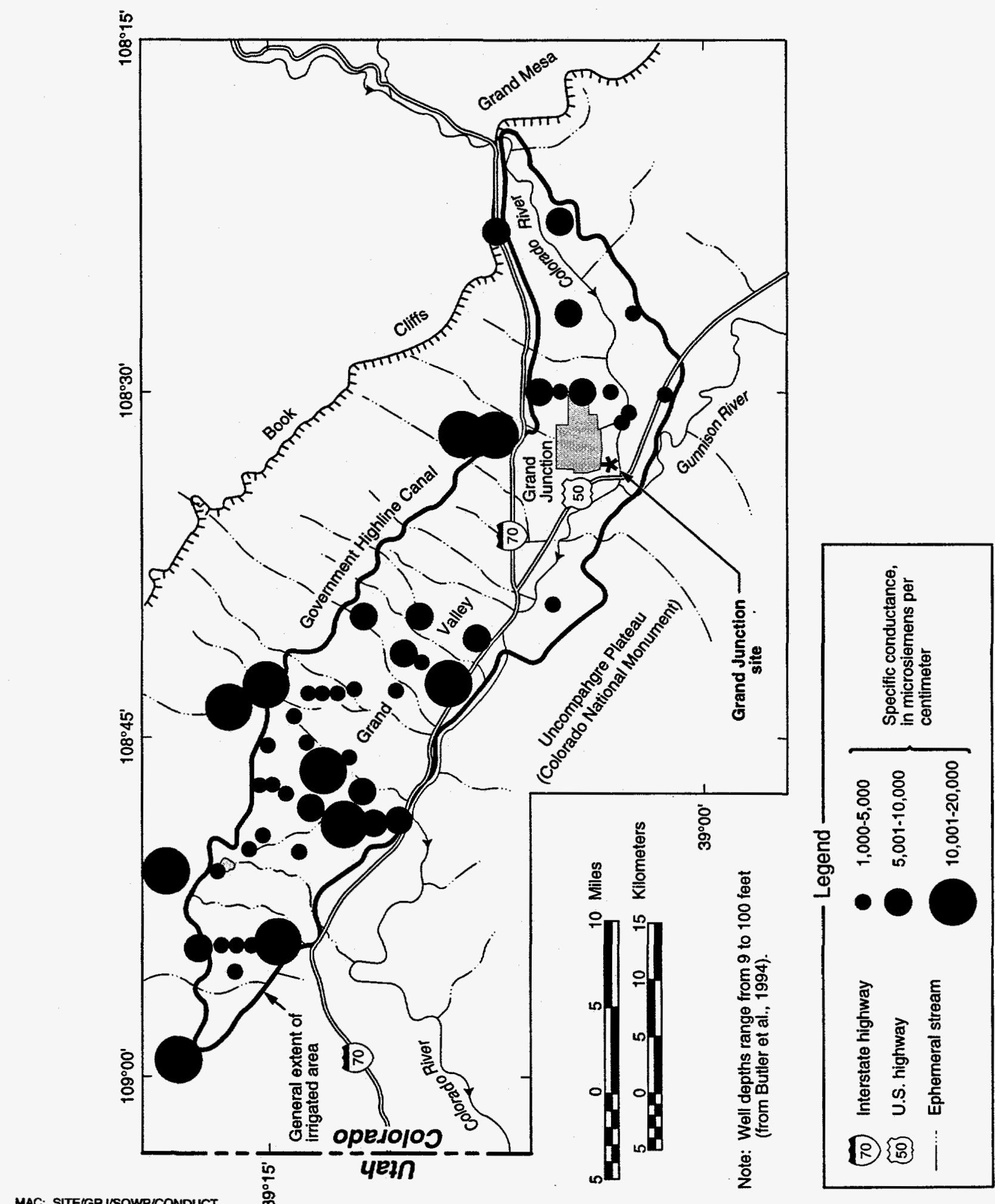

MAC: SITE/GRJ/SOWP/CONDUCT 
Further downgradient, TDS tend to increase and many samples in excess of $10,000 \mathrm{mg} / \mathrm{L}$ are observed.

The USBR is currently in the process of lining the Government Highline Canal. This action will presumably result in lowering the ground water table in the Grand Junction area and a return to higher TDS in water (more than $10,000 \mathrm{mg} / \mathrm{L}$ ) that was likely present in the area before the beginning of irrigation.

The USGS study (Butler et al., 1994) also provides information from a series of wells located in the Grand Valley alluvium outside the possible influence of vicinity properties in the Grand Junction area. Most of these wells are located in the clayey alluvium, but two are located in the cobble aquifer. One of these is clearly not influenced by tailings-related contamination because there are no vicinity properties within $1 \mathrm{mi}(1.6 \mathrm{~km})$ and none upgradient of the well. Uranium concentrations in ground water from this well have been measured at $0.054 \mathrm{mg} / \mathrm{L}$. This value exceeds the UMTRA MCL of $0.044 \mathrm{mg} / \mathrm{L}$. Uranium concentrations of up to $0.45 \mathrm{mg} / \mathrm{L}$ have been observed, and concentrations between 0.04 and $0.07 \mathrm{mg} / \mathrm{L}$ are common in ground water in wells located in the clayey alluvium. In addition, selenium concentrations in ground water in the cobble aquifer have been reported as high as $0.17 \mathrm{mg} / \mathrm{L}$. This value is 1 order of magnitude above the UMTRA MCL of $0.01 \mathrm{mg} / \mathrm{L}$. Selenium concentrations as high as $1.3 \mathrm{mg} / \mathrm{L}$ have been observed in the clayey alluvium.

These observations make it possible to characterize natural ground water quality in the alluvial aquifer in the Grand Junction area as poor and likely to get worse. TDS are currently over the 40 CFR Part 192 definition for limited-use ground water $(10,000 \mathrm{mg} / \mathrm{L})$ at many locations in the Grand Valley alluvium, and all ground water in the alluvium will likely see increases in TDS after the Government Highline Canal is lined. Uranium and selenium concentrations are currently naturally high in alluvial ground water. Concentrations of these constituents also are likely to increase when the Government Highline Canal lining project is complete.

\section{Upgradient ground water quality}

Monitor wells 745 and 746 are upgradient of the Grand Junction site and are not directly affected by activities at the site. While there is a potential for upgradient wells to be impacted by contamination from vicinity properties, the fact that ground water quality in wells 745 and 746 falls within the ranges of regional background water quality suggests that there has been little, if any, impact. Table 3.4 summarizes the minimum, median, and maximum values found for chemical parameters in the ground water from these wells and from wells accessing contaminated ground water at the site. Water quality at these locations is consistent with regional water quality downgradient of the Government Highline Canal, as described by the USGS (Butler et al., 1994) and the USBR (1978). 
The $\mathrm{pH}$ of the upgradient ground water ranges from 6.7 to 7.5. Available platinum electrode measurements of the reduction-oxidation (redox) state of the upgradient ground water are of questionable reliability. Therefore, the redox state of the alluvial aquifer is not well known. Dissolved oxygen measurements from the limited data available suggest that the upgradient ground waters are oxygen-depleted. Slightly reducing conditions in this alluvial aquifer are consistent with the presence of significant amounts of organic carbon in the ground water from these wells (averaging over $100 \mathrm{mg} / \mathrm{L}$ in monitor well 746). Organic constituents found in ground water upgradient of the site are likely from industrial or other anthropogenic sources.

The TDS in upgradient ground water samples from monitor wells 745 and 746 range from approximately 3000 to $7200 \mathrm{mg} / \mathrm{L}$. The upgradient alkalinity (as $\mathrm{mg} / \mathrm{L} \mathrm{CaCO}_{3}$ ) ranges from 343 to 439 . Despite the relatively high alkalinity of these waters, the dominant anionic species in the upgradient ground water is sulfate (median value $=2800 \mathrm{mg} / \mathrm{L}$ ). The dominant cations in the upgradient ground waters are sodium, magnesium, and calcium; median concentrations in the upgradient ground water are $659 \mathrm{mg} / \mathrm{L}$ sodium, $391 \mathrm{mg} / \mathrm{L}$ magnesium, and $532 \mathrm{mg} / \mathrm{L}$ calcium. Geochemical modeling of upgradient ground water from monitor wells 745 and 746 with the numerical code PHREEQE (Parkhurst et al., 1980 ) indicates that the ground water is at or near saturation with respect to calcite $\left(\mathrm{CaCO}_{3}\right)$, magnesite $\left(\mathrm{MgCO}_{3}\right)$, gypsum $\left(\mathrm{CaSO}_{4}\right)$, and fluorite $\left(\mathrm{CaF}_{2}\right)$. Equilibration with these minerals would explain the relatively high alkalinity and relatively high concentrations of calcium, magnesium, sulfate, and fluoride (Table 3.4) in these upgradient ground waters.

Uranium, vanadium, and selenium are also present at noteworthy levels in the upgradient ground water (Table 3.4). For example, the median concentration for uranium in the upgradient ground water was $0.046 \mathrm{mg} / \mathrm{L}$, slightly above the UMTRA MCL. Values for all these constituents, as well as TDS, are well within the observed range of concentration in alluvial ground water outside possible areas of vicinity property contamination (Butler et al., 1994).

\subsubsection{Uranium processing and process solutions}

The Climax uranium mill at Grand Junction was the first American mill designed primarily for the production of uranium with vanadium as a by-product (Merritt, 1971). The milling process used at this site was somewhat more complex than that used at newer mills. The chemicals used in the milling process are listed in Table 3.5.

The chemicals used in the milling process and the resultant dissolution of many constituents from the raw ore (including uranium and vanadium) generated a large volume of acidic process water and waste material (see Section 3.1 ) that was deposited in the evaporation ponds and tailings pile at the Grand Junction site. The tailings contained significant amounts of water-soluble radiological and chemically hazardous constituents. Much of mostly acidic process water percolated through the tailings and transported some of these water-soluble 
Table 3.4 Summary of filtered ground water quality at the Grand Junction, Colorado, site

\begin{tabular}{|c|c|c|c|c|}
\hline \multirow{2}{*}{$\begin{array}{c}\text { Constituent/ } \\
\text { sample location } \\
\text { (well GRJ-01) }\end{array}$} & \multirow{2}{*}{$\begin{array}{c}\text { Frequency of } \\
\text { detection }\end{array}$} & \multicolumn{3}{|c|}{ Observed concentration } \\
\hline & & Minimum & Median & Maximum \\
\hline \multicolumn{5}{|c|}{ Inorganic constituents (mg/L) } \\
\hline \multicolumn{5}{|l|}{ Aluminum } \\
\hline Upgradient $^{c}$ & $9 / 26$ & 0.048 & - & 0.38 \\
\hline Plume $^{d}$ & $5 / 23$ & 0.004 & - & 0.51 \\
\hline \multicolumn{5}{|l|}{ Ammonium $^{e}$} \\
\hline Upgradient & $23 / 32$ & $<0.03$ & 0.2 & 0.6 \\
\hline Plume & $23 / 23$ & 166 & 357 & 521 \\
\hline \multicolumn{5}{|l|}{ Antimony } \\
\hline Upgradient & $4 / 22$ & $<0.003$ & - & 0.012 \\
\hline Plume & $2 / 23$ & $<0.003$ & - & 0.012 \\
\hline \multicolumn{5}{|l|}{ Arsenic $^{e}$} \\
\hline Upgradient & $7 / 30$ & 0.001 & - & 0.04 \\
\hline Plume (-0584) & $6 / 6$ & 0.007 & 0.08 & 0.18 \\
\hline \multicolumn{5}{|l|}{ Barium } \\
\hline Upgradient & $10 / 26$ & $<0.002$ & - & 0.02 \\
\hline Plume & $11 / 21$ & 0.002 & - & 0.30 \\
\hline \multicolumn{5}{|l|}{ Beryllium } \\
\hline Upgradient & $0 / 16$ & $<0.001$ & - & $<0.01$ \\
\hline Plume & $0 / 3$ & $<0.005$ & - & $<0.005$ \\
\hline \multicolumn{5}{|l|}{ Boron } \\
\hline Upgradient & $16 / 16$ & 0.36 & 0.59 & 0.83 \\
\hline Plume & $15 / 15$ & 0.34 & 0.57 & 0.71 \\
\hline \multicolumn{5}{|l|}{ Bromide } \\
\hline Upgradient & $4 / 10$ & 0.1 & - & 0.6 \\
\hline Plume & $1 / 1$ & - & - & 471 \\
\hline \multicolumn{5}{|l|}{ Cadmium $^{e}$} \\
\hline Upgradient & $7 / 26$ & $<0.001$ & - & 0.04 \\
\hline Plume $\{-0584\}$ & $4 / 4$ & 0.073 & 0.12 & 0.42 \\
\hline
\end{tabular}


Table 3.4 Summary of filtered ground water quality at the Grand Junction, Colorado, site (Continued)

\begin{tabular}{|c|c|c|c|c|}
\hline \multirow{2}{*}{$\begin{array}{c}\text { Constituent/ } \\
\text { sample location } \\
\text { (well GRJ-01) }\end{array}$} & \multirow{2}{*}{$\begin{array}{l}\text { Frequency of } \\
\text { detection }^{\text {a }}\end{array}$} & \multicolumn{3}{|c|}{ Observed concentration } \\
\hline & & Minimum & Median $^{6}$ & Maximum \\
\hline \multicolumn{5}{|l|}{ Calcium ${ }^{e}$} \\
\hline Upgradient & $30 / 30$ & 325 & 445 & 595 \\
\hline Plume & $33 / 33$ & 360 & 545 & 654 \\
\hline \multicolumn{5}{|l|}{ Chloride $^{e}$} \\
\hline Upgradient & $30 / 30$ & 306 & 598 & 2400 \\
\hline Plume & $33 / 33$ & 490 & 791 & 970 \\
\hline \multicolumn{5}{|l|}{ Chromium } \\
\hline Upgradient & $5 / 26$ & $<0.003$ & - & 0.15 \\
\hline Plume & $20 / 32$ & $<0.001$ & 0.01 & 0.03 \\
\hline \multicolumn{5}{|l|}{ Cobalt $^{e}$} \\
\hline Upgradient & $2 / 22$ & $<0.003$ & - & 0.01 \\
\hline Plume (-0584) & $6 / 6$ & 0.05 & 0.14 & 0.66 \\
\hline \multicolumn{5}{|l|}{ Copper $^{e}$} \\
\hline Upgradient & $10 / 26$ & 0.003 & - & 0.03 \\
\hline Plume & $22 / 33$ & $<0.001$ & 0.02 & 0.20 \\
\hline \multicolumn{5}{|l|}{ Cyanide } \\
\hline Upgradient & $0 / 20$ & $<0.01$ & - & $<0.01$ \\
\hline Plume & $0 / 13$ & $<0.01$ & - & $<0.01$ \\
\hline \multicolumn{5}{|l|}{ Fluoride $^{e}$} \\
\hline Upgradient & $26 / 26$ & 0.6 & 1.0 & 1.7 \\
\hline Plume (-0581) & $5 / 5$ & 4.3 & 4.6 & 4.8 \\
\hline \multicolumn{5}{|l|}{$\operatorname{Iron}^{e}$} \\
\hline Upgradient & $23 / 30$ & $<0.005$ & 0.4 & 2.2 \\
\hline $\begin{array}{l}\text { Plume }(-0581,-0585 \\
-0586)\end{array}$ & $21 / 21$ & 1.3 & 11 & 16 \\
\hline \multicolumn{5}{|l|}{ Lead } \\
\hline Upgradient & $2 / 24$ & $<0.001$ & - & 0.01 \\
\hline Plume & $1 / 17$ & $<0.001$ & - & 0.01 \\
\hline \multicolumn{5}{|l|}{ Magnesium } \\
\hline Upgradient & $30 / 30$ & 210 & 391 & 570 \\
\hline Plume & $33 / 33$ & 25 & 282 & 620 \\
\hline
\end{tabular}


Table 3.4 Summary of filtered ground water quality at the Grand Junction, Colorado, site (Continued)

\begin{tabular}{|c|c|c|c|c|}
\hline \multirow{2}{*}{$\begin{array}{c}\text { Constituent/ } \\
\text { sample location } \\
\text { (well GRJ-01) }\end{array}$} & \multirow{2}{*}{$\begin{array}{c}\text { Frequency of } \\
\text { detection }\end{array}$} & \multicolumn{3}{|c|}{ Observed concentration } \\
\hline & & Minimum & Median $^{b}$ & Maximum \\
\hline \multicolumn{5}{|l|}{ Manganese $^{e}$} \\
\hline Upgradient & $30 / 30$ & 0.9 & 1.3 & 2.3 \\
\hline $\begin{array}{l}\text { Plume }(-0583,-0584 \\
-0585,-0586)\end{array}$ & $26 / 26$ & 1.8 & 4.1 & 10 \\
\hline Plume & $3 / 23$ & $<0.0001$ & - & 0.0004 \\
\hline \multicolumn{5}{|l|}{ Molybdenum $^{e}$} \\
\hline Upgradient & $28 / 28$ & 0.01 & 0.11 & 0.23 \\
\hline $\begin{array}{l}\text { Plume }(-0583,-0584 \text {, } \\
-0585,-0586)\end{array}$ & $26 / 26$ & 0.13 & 0.28 & 0.53 \\
\hline \multicolumn{5}{|l|}{ Nickel $^{e}$} \\
\hline Upgradient & $5 / 26$ & $<0.006$ & - & 0.12 \\
\hline Plume (-0584) & $3 / 3$ & 0.28 & 0.32 & 0.38 \\
\hline \multicolumn{5}{|l|}{ Nitrate } \\
\hline Upgradient & $15 / 32$ & $<0.1$ & - & 16 \\
\hline Plume & $11 / 28$ & $<0.01$ & - & 50 \\
\hline \multicolumn{5}{|l|}{ Phosphate } \\
\hline Upgradient & $4 / 14$ & $<0.05$ & - & 0.1 \\
\hline Plume & $0 / 10$ & $<0.1$ & - & $<0.1$ \\
\hline \multicolumn{5}{|l|}{ Potassium $^{e}$} \\
\hline Upgradient & $30 / 30$ & 4.2 & 8.1 & 12 \\
\hline Plume & $33 / 33$ & 49 & 96 & 120 \\
\hline \multicolumn{5}{|l|}{ Selenium } \\
\hline Upgradient & $16 / 32$ & $<0.001$ & - & 0.19 \\
\hline Plume & $13 / 33$ & $<0.002$ & - & 0.24 \\
\hline \multicolumn{5}{|l|}{ Silica } \\
\hline Upgradient & $16 / 16$ & 8 & 17 & 18 \\
\hline Plume & $20 / 20$ & 9 & 17 & 29 \\
\hline \multicolumn{5}{|l|}{ Silver } \\
\hline Upgradient & $1 / 20$ & $<0.002$ & - & 0.01 \\
\hline Plume & $4 / 18$ & $<0.002$ & - & 0.004 \\
\hline
\end{tabular}


Table 3.4 Summary of filtered ground water quality at the Grand Junction, Colorado, site (Continued)

\begin{tabular}{|c|c|c|c|c|}
\hline \multirow{2}{*}{$\begin{array}{l}\text { Constituent/ } \\
\text { sample location } \\
\text { (well GRJ-01) }\end{array}$} & \multirow{2}{*}{$\begin{array}{c}\text { Frequency of } \\
\text { detection }\end{array}$} & \multicolumn{3}{|c|}{ Observed concentration } \\
\hline & & Minimum & Median $^{6}$ & Maximum \\
\hline \multicolumn{5}{|l|}{ Sodium $^{\theta}$} \\
\hline Upgradient & $30 / 30$ & 345 & 659 & 910 \\
\hline Plume & $33 / 33$ & 520 & 950 & 1210 \\
\hline \multicolumn{5}{|l|}{ Strontium } \\
\hline Upgradient & $32 / 32$ & 3.2 & 5.2 & 7.1 \\
\hline Plume & $18 / 18$ & 3.6 & 4.7 & 7.3 \\
\hline \multicolumn{5}{|l|}{ Sulfate $e^{e}$} \\
\hline Upgradient & $32 / 32$ & 1450 & 2800 & 11,000 \\
\hline $\begin{array}{l}\text { Plume }(-0583,-0584 \\
-0585,-0586)\end{array}$ & $26 / 26$ & 3100 & 3945 & 4,900 \\
\hline \multicolumn{5}{|l|}{ Sulfide } \\
\hline Upgradient & $7 / 12$ & $<0.1$ & 0.4 & 40 \\
\hline Plume & $2 / 5$ & $<0.1$ & - & 0.2 \\
\hline \multicolumn{5}{|l|}{ Thallium } \\
\hline Upgradient & $0 / 16$ & $<0.005$ & - & $<0.1$ \\
\hline Plume & $0 / 3$ & $<0.1$ & - & $<0.1$ \\
\hline \multicolumn{5}{|l|}{ Tin } \\
\hline Upgradient & $4 / 22$ & $<0.005$ & - & 0.11 \\
\hline Plume & $3 / 18$ & $<0.005$ & - & 0.008 \\
\hline \multicolumn{5}{|l|}{ Uranium $^{e}$} \\
\hline Upgradient & $26 / 26$ & 0.017 & 0.046 & 0.072 \\
\hline Plume $(-0585,-0586)$ & $4 / 4$ & 0.29 & 0.30 & 0.45 \\
\hline \multicolumn{5}{|l|}{ Vanadium } \\
\hline Upgradient & $8 / 28$ & $<0.005$ & - & 0.11 \\
\hline Plume (-0584) & $6 / 6$ & 5.2 & 7.1 & 14 \\
\hline \multicolumn{5}{|l|}{$\operatorname{Zinc}^{\circ}$} \\
\hline Upgradient & $7 / 26$ & $<0.002$ & - & 1.0 \\
\hline Plume (-0584) & $5 / 5$ & 2.6 & 4.5 & 6.7 \\
\hline
\end{tabular}


Table 3.4 Summary of filtered ground water quality at the Grand Junction, Colorado, site (Concluded)

\begin{tabular}{|c|c|c|c|c|}
\hline \multirow{2}{*}{$\begin{array}{l}\text { Constituent/ } \\
\text { sample location } \\
\text { (well GRJ-01) }\end{array}$} & \multirow{2}{*}{$\begin{array}{c}\text { Frequency of } \\
\text { detection }\end{array}$} & \multicolumn{3}{|c|}{ Observed concentration } \\
\hline & & Minimum & Median & Maximum \\
\hline \multicolumn{5}{|c|}{ Radionuclides (pCi/L) } \\
\hline \multicolumn{5}{|l|}{ Lead-210 } \\
\hline Upgradient & $0 / 4$ & $<1.5$ & - & $<1.5$ \\
\hline Plume & $4 / 10$ & $<1.5$ & - & 2.8 \\
\hline \multicolumn{5}{|l|}{ Polonium-210 } \\
\hline Upgradient & $0 / 4$ & $<1.0$ & - & $<1.0$ \\
\hline Plume & $1 / 10$ & $<1.0$ & - & 1.1 \\
\hline \multicolumn{5}{|l|}{ Radium-226 } \\
\hline Upgradient & $26 / 32$ & 0.0 & 0.1 & 2.3 \\
\hline Plume & $19 / 22$ & 0.0 & 2.1 & 29 \\
\hline \multicolumn{5}{|l|}{ Thorium-230 } \\
\hline Upgradient & $18 / 22$ & 0.0 & 0.1 & 0.6 \\
\hline Plume & $6 / 17$ & 0.2 & - & 5.4 \\
\hline \multicolumn{5}{|l|}{ Uranium-234 ${ }^{\mathrm{e}}$} \\
\hline Upgradient & $6 / 6$ & 17 & 21 & 35 \\
\hline Plume & $10 / 10$ & 23 & 56 & 118 \\
\hline \multicolumn{5}{|l|}{ Uranium-238 } \\
\hline Upgradient & $6 / 6$ & 11 & 15 & 27 \\
\hline Plume & $10 / 10$ & 23 & 58 & 116 \\
\hline
\end{tabular}

${ }^{\mathrm{a}}$ Frequency of detection $=$ number of measurements above laboratory detection limit/total number of measurements.

${ }^{b}$ Calculation of the median requires that more than 50 percent of the measurements be above detection. A dash $\left("{ }^{n}\right)$ in the median column indicates that the median cannot be calculated.

¿Upgradient concentrations are from monitor wells 745 and 746 (both sampled 1985 to 1993).

'Plume concentrations are from monitor wells GRJ-01-0583 and -0584 (sampled 1983 to 1985); -0581,

-0585 , and -0586 (sampled 1983 to 1989 ). Summary statistics are from all five wells unless otherwise noted.

${ }^{\circ}$ Constituent concentrations in plume wells are statistically elevated above upgradient concentrations.

pCi/L - picocuries per liter. 
Table 3.5 Major chemicals used at the former Climax mill in Grand Junction, Colorado

\begin{tabular}{ll}
\hline \multicolumn{1}{c}{ Inorganics } & \multicolumn{1}{c}{ Organics } \\
\hline Sulfuric acid & Number 2 fuel oil or kerosene \\
Hydrochloric acid & Di(2-ethylhexyl) phosphoric acid \\
Sodium chlorate & Tributyl phosphate \\
Ammonia & Tertiary amines \\
Sodium chloride & \\
Sodium carbonate & \\
Hydrogen peroxide & \\
Powdered iron metal & \\
\hline
\end{tabular}

From Merritt, 1971.

constituents from the tailings as leachate. Also, the Climax mill used an organic solvent extraction process to recover uranium from the pregnant solution during the milling process. However, ground water at the site was screened for the organic constituents listed in 40 CFR Part 264, Appendix IX, in 1988, and no organic contamination, as represented by the Appendix IX analyte list, was found.

\subsubsection{Magnitude and extent of ground water contamination}

A large volume of acidic pore water from the tailings and acidic process water from the evaporation ponds has leached into and variably contaminated the subjacent alluvial ground water system at the Grand Junction site (see Section 3.1). Chemical analysis of leachate from lysimeters installed just above the tailings/alluvium interface reveals that the tailings leachate was significantly enriched in many major, minor, and trace constituents relative to upgradient alluvial ground water (Table 3.6). The chemical interaction of the tailings leachate with the alluvial system produced contaminated alluvial ground water. The TDS of ground water beneath the site range from 3000 to $10,000 \mathrm{mg} / \mathrm{L}$.

This contaminated water is migrating along the ground water flow path shown in Figure 3.9 and ultimately discharges to the Colorado River as can be seen in the uranium isopleth map (Figure 3.15).

Monitor wells downgradient from the site commonly have levels of ammonium, uranium, chloride, and sulfate that are above upgradient levels. Ammonium is strongly adsorbed by clays and is not very mobile, however, and the migration of this constituent away from the site has lagged well behind the more mobile species such as sulfate, chloride, or uranium. The current downgradient extent of the contaminated ground water cannot be precisely defined because of the lack of recent chemical data from on-site and some downgradient monitor wells 
Table 3.6 Typical tailings lysimeter and upgradient water quality for the Grand Junction, Colorado, site

\begin{tabular}{|c|c|c|c|c|c|}
\hline Parameter & $\begin{array}{l}\text { Lysimeter } \\
550^{\circ}\end{array}$ & $\begin{array}{l}\text { Lysimeter } \\
552^{\circ}\end{array}$ & $\begin{array}{l}\text { Lysimeter } \\
\qquad 553^{\circ}\end{array}$ & $\begin{array}{l}\text { Upgradient } \\
\text { well } 745^{b}\end{array}$ & $\begin{array}{l}\text { Upgradient } \\
\text { well } 746^{c}\end{array}$ \\
\hline $\mathrm{pH}$ & 6.77 & NA & 4.25 & 7.32 & 7.06 \\
\hline Conductivity (mS/cm) & 11,500 & NA & 10,000 & 3,080 & 7,340 \\
\hline Temperature $\left({ }^{\circ} \mathrm{C}\right)$ & 26.0 & NA & 21.0 & 12.2 & 14.9 \\
\hline Alkalinity & 770 & NA & & 485 & 425 \\
\hline TDS & 10,156 & NA & 8,274 & 3,550 & 6,820 \\
\hline Aluminum & $<0.50$ & 82.9 & 25.3 & NA & $<0.05$ \\
\hline Ammonium & 897 & NA & 780 & 0.4 & 0.2 \\
\hline Antimony & 0.020 & $<0.010$ & 0.013 & NA & 0.004 \\
\hline Arsenic & 0.090 & 0.050 & 0.640 & $<0.005$ & $<0.05$ \\
\hline Boron & 0.60 & NA & 1.00 & NA & 0.68 \\
\hline Cadmium & 0.0071 & 0.3500 & 0.2700 & NA & $<0.001$ \\
\hline Calcium & 470 & NA & 670 & 330 & 488 \\
\hline Chloride & 1,450 & NA & 1,100 & 404 & 689 \\
\hline Chromium & 0.10 & 0.10 & 0.10 & NA & $<0.01$ \\
\hline Cobalt & 0.20 & 0.70 & 0.60 & NA & $<0.03$ \\
\hline Copper & 0.10 & 2.70 & 2.90 & NA & $<0.01$ \\
\hline Fluoride & 4.1 & NA & 12.8 & 0.8 & 1.7 \\
\hline Iron & 7.60 & 1.50 & 53.0 & 0.52 & $<0.03$ \\
\hline Lead & 0.016 & 0.080 & 0.033 & $<0.003$ & $<0.03$ \\
\hline Magnesium & 410 & NA & 275 & 221.0 & 495 \\
\hline Manganese & 7.50 & 8.90 & 7.60 & 0.96 & 1.32 \\
\hline Mercury & $<0.0001$ & $<0.0001$ & $<0.0001$ & NA & $<0.0002$ \\
\hline Molybdenum & 0.90 & $<0.50$ & $<0.50$ & 0.04 & 0.15 \\
\hline Nickel & 0.80 & 4.20 & 1.80 & NA & $<0.04$ \\
\hline Nitrate & $<0.1$ & NA & 0.2 & $<1$ & 9.7 \\
\hline Phosphate & 0.1 & NA & 0.3 & NA & 0.1 \\
\hline Potassium & 180 & NA & 140 & 4.6 & 9.19 \\
\hline
\end{tabular}


Table 3.6 Typical tailings lysimeter and upgradient water quality for the Grand Junction, Colorado, site (Concluded)

\begin{tabular}{|c|c|c|c|c|c|}
\hline Parameter & $\begin{array}{c}\text { Lysimeter } \\
550^{\circ}\end{array}$ & $\begin{array}{c}\text { Lysimeter } \\
552^{\circ}\end{array}$ & $\begin{array}{c}\text { Lysimeter } \\
553^{\circ}\end{array}$ & $\begin{array}{l}\text { Upgradient } \\
\text { well } 745^{b}\end{array}$ & $\begin{array}{l}\text { Upgradient } \\
\text { well } 746^{c}\end{array}$ \\
\hline Selenium & 0.21 & 0.8 & 0.08 & $<0.005$ & 0.11 \\
\hline Silica & 27.5 & NA & 82.5 & 16.7 & 18.3 \\
\hline Silver & $<0.0001$ & 0.0016 & 0.0004 & NA & $<0.01$ \\
\hline Sodium & 1,145 & NA & 670 & 401.0 & 844 \\
\hline Strontium & 4.20 & 5.50 & 4.80 & 3.41 & 6.57 \\
\hline Sulfate & 2,307 & NA & 2,540 & 1,790 & 3,600 \\
\hline Tin & 0.010 & $<0.010$ & $<0.010$ & NA & $<0.03$ \\
\hline Uranium & 2.897 & 3.050 & 0.180 & 0.030 & 0.060 \\
\hline Vanadium & 1.00 & 0.40 & 2.90 & NA & $<0.01$ \\
\hline Zinc & 0.50 & 6.70 & 7.00 & NA & $<0.05$ \\
\hline
\end{tabular}

All units are $\mathrm{mg} / \mathrm{L}$ unless otherwise noted.

${ }^{a}$ Lysimeter water quality data are a composite of August 1989 and October 1989 data.

bupgradient water quality data from February 1993.

'Upgradient water quality data from February 1992.

NA - not analyzed.

${ }^{\circ} \mathrm{C}$ - degrees Celsius. 


\section{Figure 3.15}

\section{Distribution of Uranium in Alluvial Ground Water (December 1994) in the Grand Junction, Colorado, Site Vicinity}

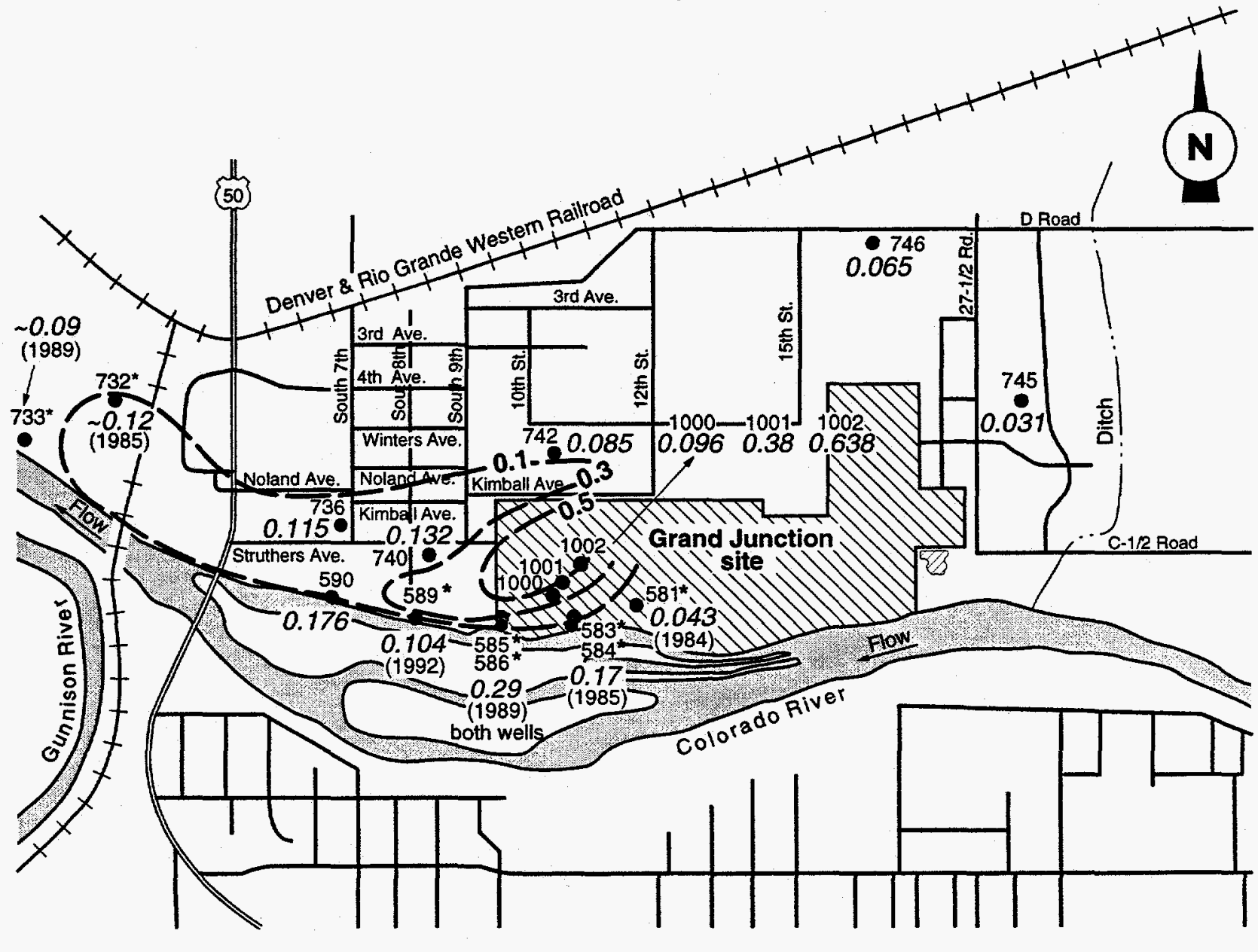

Source: DOE, 1995b.

Notes: 1. Decommissioned monitor wells are indicated by an asterisk.

Legend

2. On-site ponds are not shown.

$$
\begin{array}{cl}
0.1- & \begin{array}{l}
\text { Uranium concentration contour line } \\
(\mathrm{mg} / \mathrm{L})-\text { dashed where inferred }
\end{array} \\
740 & \text { Alluvial monitor well } \\
0.132 & \text { Uranium concentrations (mg/L) } \\
8 & \text { Pond } \\
50 & \text { U.S. highway }
\end{array}
$$


and the masking effects of the high upgradient levels of many of the most mobile tracer constituents (e.g., uranium, sulfate, and chloride) in the alluvium (Table 3.4).

The water quality data from monitor wells $581,583,584,585,586,589,740$, 736 , and 733 indicate that the wells farthest downgradient from the site, wells 736 and 733 , show lower levels of potential site-related contamination than do the wells closer to the site. Therefore, these wells were eliminated from a determination of the magnitude of contamination.

Data from the other wells $(581,583,584,585,589,740$, and 590$)$ were analyzed to identify where the highest levels of contamination occurred before the tailings pile was removed and to quantify those levels. The analysis was complicated by the fact that the wells on the site have not been sampled recently and, in fact, no longer exist. On-site concentrations of milling-related contaminants between 1983 and 1989 were generally higher than off-site levels during the same time period, as well as higher than subsequent off-site levels measured between 1991 and 1993. Trend analyses of five constituents associated with uranium milling (chloride, sulfate, ammonium, uranium, and molybdenum) suggest that molybdenum concentrations at the site decreased by about half between 1983 and 1989 . On-site sulfate concentrations may also be decreasing, but only slightly. Chloride, ammonium, and uranium concentrations were steady. These data indicate that, as expected, some constituents (molybdenum and possibly sulfate) are being attenuated by adsorption and precipitation processes at the site. Analysis of water from monitor wells 1000 , 1001 , and 1002 (which were installed after the tailings were removed) indicates that there have been no appreciable changes in contaminant distribution in the short time since tailings were removed.

The off-site wells located near, but downgradient from, the site $(589,590$, and 740) were also studied for possible time trends in concentration levels.

Between 1983 and 1995, chloride and sulfate levels in well 589 appear to have peaked and may be starting to decline. Uranium levels in this well are clearly decreasing with time. In the two other off-site wells, 590 and 740 , located slightly farther from the site, chloride and sulfate concentrations appear to be increasing, but uranium is fairly steady with time. Although wells located off the site show trends over time between 1983 and 1995, these trends do not necessarily agree in magnitude or direction. Based on these analyses, it was concluded that the highest concentrations of milling-related contaminants in the alluvial aquifer probably are still under the site itself at levels comparable to those measured in 1989. Ground water quality in on-site wells 581 and 583 through 586 from 1983 to 1989 is summarized in Table 3.4.

\subsubsection{Surface water quality}

Surface water quality has been monitored for several years in the Colorado River in the vicinity of the Grand Junction site. The locations of the surface water sampling points are shown in Figure 3.16. Five locations have been sampled: 
SITE OBSERVATIONAL WORK PLAN FOR THE

UMTRA PROJECT SITE AT GRAND JUNCTION, COLORADO

SITE CONDITIONS

\section{Figure 3.16}

\section{Surface Water and Sediment Sample Locations}

Locations of Wetland Ponds as They Appeared in November 1994

Grand Junction, Colorado, Site Vicinity

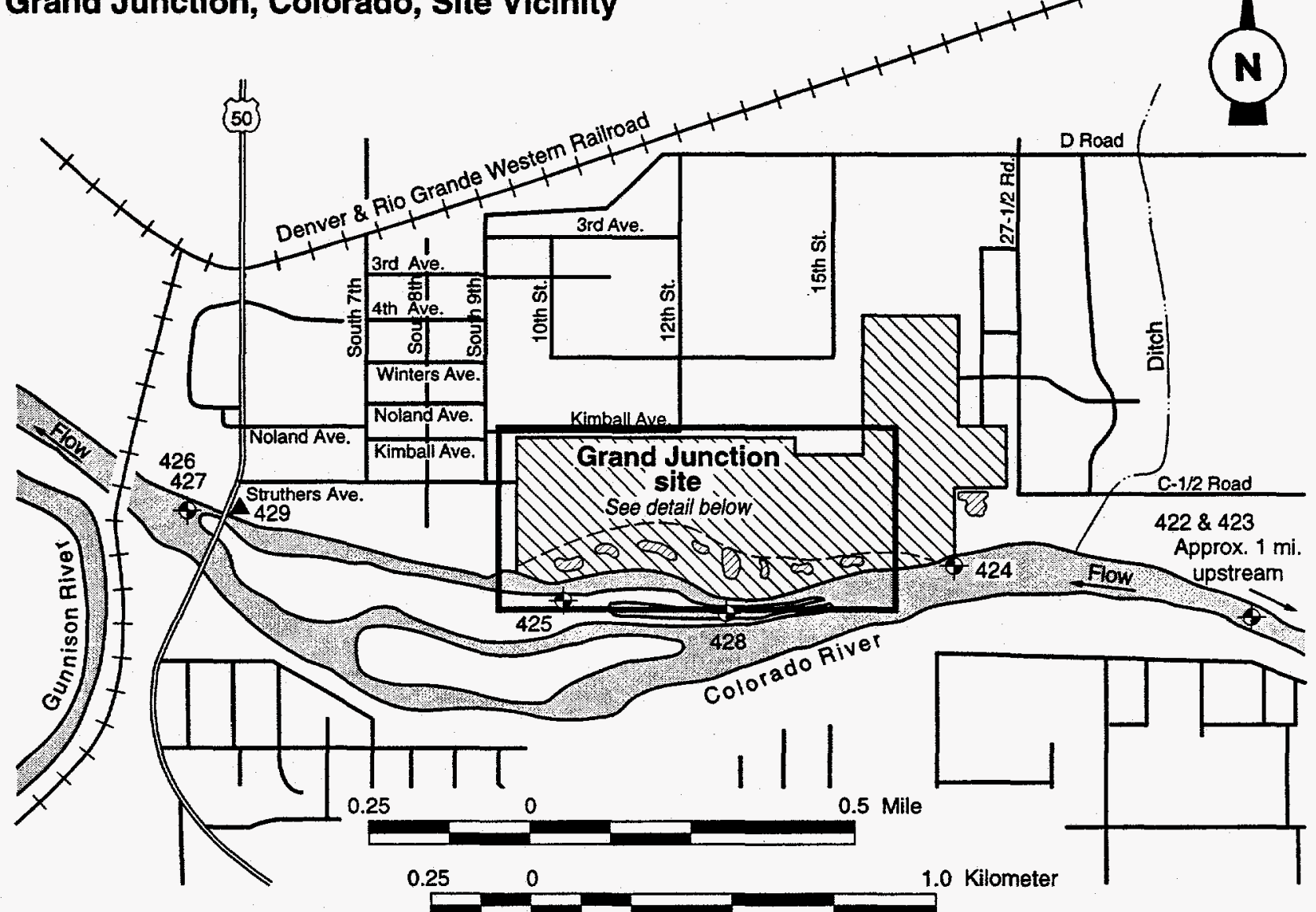

Source: DOE, 1995.

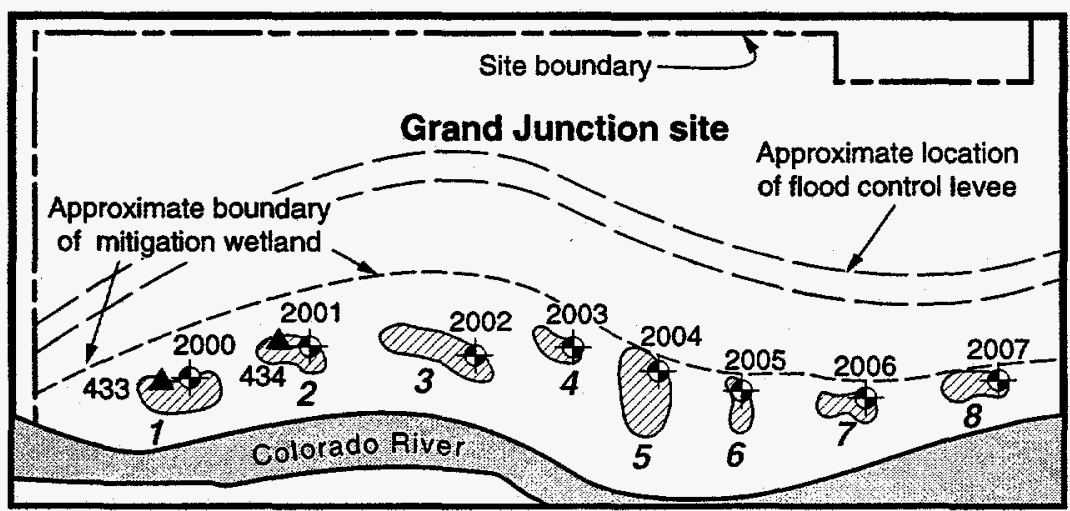

Notes: 1. Data collected January 1995.

2. Samples are filtered.

3. On-site ponds shown as they appeared in November 1994

Detail of surface water sampling locations

\begin{tabular}{|llll|}
\hline$\phi^{2007}$ & Surface water and sediment sampling location & $\widetilde{50}^{7}$ & Pond \\
$\Delta^{433}$ & Staff gauge & U.S. highway
\end{tabular}

MAC: SITEJGRJ/SOWPNETPONDS 
one location upstream of the site, three locations adjacent to the site, and one location downstream of the site. Filtered samples were collected once, in 1991 , from upstream of the site (location 423), adjacent to the site (locations 424 and 425), and downstream of the site (location 427). Between 1991 and 1993, six rounds of unfiltered samples were collected from these four locations. It should be noted that some of the sampling events occurred during low-flow conditions, which provides a conservative picture of ground water contribution to the river. At the upstream and downstream locations, the unfiltered samples were designated with location identifications of 422 and 426 , respectively. One unfiltered sample was collected from location 428 in 1993. The samples collected from 1991 through 1992 were analyzed for a full suite of analytes. The samples collected in September 1993 were analyzed for a select list of analytes (molybdenum, selenium, strontium, sulfate, and uranium). Sediment samples were also collected in September 1993 from the same five surface water locations and analyzed for the same constituents.

Surface water data from the Colorado River show that most of the constituents detected at the adjacent and downstream locations were not greater than their respective upstream concentrations. From the list of ground water contaminants that are identified as exceeding upgradient ground water quality (Table 3.4), only ammonium, copper, iron, radium-226, uranium, and vanadium were detected at concentrations slightly above upstream levels at the adjacent locations adjacent to or downstream from the site. However, the differences are not statistically significant. This indicates that site-related contamination has not adversely affected the water quality of the Colorado River.

A series of eight ponds, illustrated in Figure 3.16, were constructed in a wetland along the southern boundary of the site in 1994. These ponds were sampled once in January 1995 before they were destroyed by flooding in the late spring and early summer of 1995 . Observations in September 1995 indicate that ponds 1 and 2 were completely filled with silt and had no water in them. The remaining ponds held much less water then when they originally were constructed.

These ponds were fed by ground water and, thus, provide some indication of the distribution of ground water contamination at the site. For example, the most highly contaminated ponds were the two at the western edge of the site, indicating that the bulk of ground water contamination is located in the western portion of the site. However, contaminant levels in these ponds probably had been increased by evaporation relative to contaminant levels in nearby monitor wells. By way of illustration, the uranium concentration in ground water in monitor well 1000 is $0.096 \mathrm{mg} / \mathrm{L}$ while the surface water in pond 2000 , less than $200 \mathrm{ft}(60 \mathrm{~m})$ downgradient, contained $0.473 \mathrm{mg} / \mathrm{L}$ of uranium (approximately a five-fold increase). Data from the January 1995 sampling of ponds at the Grand Junction site are given in Table 3.7. 
Table 3.7 Concentrations of selected contaminants in water from the January 1995 sampling of ponds at the Grand Junction, Colorado, site

\begin{tabular}{lcccccccc}
\hline & \multicolumn{7}{c}{ Sample ID } \\
\cline { 2 - 9 } Contaminant & $\begin{array}{c}\text { 2000 } \\
\text { (pond 1) }\end{array}$ & $\begin{array}{c}\text { Concentrations } \\
\text { (pond 2) }\end{array}$ & $\begin{array}{c}\text { (pond 3) } \\
\text { (pond }\end{array}$ & $\begin{array}{c}\text { (pond 4) } \\
\text { (pon }\end{array}$ & $\begin{array}{c}\text { 2004 } \\
\text { (pond 5) }\end{array}$ & $\begin{array}{c}\text { 2005 } \\
\text { (pond 6) }\end{array}$ & $\begin{array}{c}\text { 2006 } \\
\text { (pond 7) }\end{array}$ & $\begin{array}{c}\text { 2007 } \\
\text { (pond 8) }\end{array}$ \\
\hline Arsenic & $<0.01$ & $<0.005$ & $<0.005$ & $<0.01$ & $<0.005$ & $<0.005$ & $<0.005$ & $<0.005$ \\
Cadmium & 0.003 & 0.004 & 0.04 & 0.001 & $<0.001$ & $<0.001$ & 0.001 & $<0.001$ \\
Cobalt & $<0.05$ & $<0.05$ & $<0.05$ & $<0.05$ & $<0.05$ & $<0.05$ & $<0.05$ & $<0.05$ \\
Fluoride & 4 & 3 & 2.2 & 8 & 2.5 & 2 & 0.8 & 0.6 \\
Iron & $<0.03$ & $<0.03$ & $<0.03$ & $<0.03$ & $<0.03$ & $<0.03$ & $<0.03$ & 0.27 \\
Manganese & 0.84 & 2.36 & 1.97 & 0.33 & 2.71 & 0.49 & 0.78 & 1.02 \\
Molybdenum & 0.18 & 0.09 & 0.02 & 0.07 & 0.05 & $<0.01$ & 0.01 & $<0.01$ \\
Nickel & 0.07 & 0.07 & 0.04 & 0.04 & $<0.04$ & $<0.04$ & $<0.04$ & $<0.04$ \\
Radium-226 & 0.1 & 0.6 & 0.4 & 0.1 & 0.1 & 0.2 & 0.4 & 0.3 \\
Sulfate & 4960 & 3380 & 2690 & 4320 & 2710 & 2510 & 3180 & 463 \\
Uranium & 0.473 & 0.154 & 0.04 & 0.032 & 0.068 & 0.039 & 0.07 & 0.023 \\
Vanadium & 0.47 & 0.43 & 0.03 & $<0.01$ & $<0.01$ & $<0.01$ & $<0.01$ & $<0.01$ \\
Zinc & 0.05 & 0.21 & $<0.05$ & $<0.05$ & $<0.05$ & $<0.05$ & $<0.05$ & $<0.05$ \\
\hline
\end{tabular}

Note: Refer to Figure $\mathbf{3 . 1 6}$ for pond locations.

Concentrations are reported in milligrams per liter, except for radium-226, which is reported in picocuries per liter. 


\subsubsection{Contaminants of potential concern}

The data summarized in Table 3.4 were used to compile a list of contaminants of potential concern for the assessment of potential human health and ecological risks at the Grand Junction site (Table 3.8). A contaminant was placed on the list if concentrations of the contaminant in on-site wells were, on average, higher than those in the off-site upgradient wells (DOE, 1995b).

The contaminants identified in the first column of Table 3.8 were screened for their impact on human health, using the criteria discussed below to develop a final list of contaminants of potential concern for human health. If the maximum detected concentration of a contaminant on the screening list fell into acceptable nutritional requirement levels that would not be exceeded with exposure, it was not retained as a contaminant of potential concern. The contaminants that fell into this category were calcium, chloride, and potassium. If the maximum detected concentration of a contaminant on the screening list fell into the high end of expected dietary ranges but was of low toxicity, it was not retained as a contaminant of potential concern. The contaminants that fell into this category were ammonium, copper, and sodium. All remaining contaminants on the list are considered contaminants of potential concern because of the potential for toxic effects if people are exposed to the contaminants at their maximum detected levels in ground water. These contaminants were evaluated quantitatively in the BLRA (DOE, 1995b).

\subsubsection{Fate and transport of contaminants of potential concern}

Although the aqueous speciation of a contaminant in solution is one of the major determinants of its mobility in an aquifer, speciation can also influence the toxicity of some contaminants. For example, trivalent arsenic species are more toxic to humans than arsenic in the pentavalent state. To determine the probable predominant species for the contaminants of potential concern, the geochemical code PHREEQE (Parkhurst et al., 1980) was used to model the ground water chemistry of plume-affected alluvial ground water. Although the redox state of the ground water at Grand Junction is not well defined, the dominant solution species for the contaminants of potential concern at a redox potential (Eh) of 150 millivolts ( $\mathrm{mV}$ ) are listed in Table 3.9. An Eh of $150 \mathrm{mV}$ is a realistic estimate given the overall chemistry of the alluvial aquifer.

\section{Fate and transport of metallic contaminants}

The solubility and mobility of metals and metalloids (e.g., iron, chromium, arsenic, and selenium) vary dramatically as a function of water chemistry (e.g., $\mathrm{pH}$, Eh, and ionic strength), aquifer matrix composition, and the chemical characteristics of the contaminant. Nevertheless, some basic similarities in the aqueous chemistry of many metallic contaminants allow us to group the contaminants of potential concern at the Grand Junction site according to similar fate and transport characteristics. 
Table 3.8 Contaminants of potential concern for human health evaluation, Grand Junction, Colorado, site

\begin{tabular}{|c|c|c|c|}
\hline $\begin{array}{l}\text { Contaminants that } \\
\text { exceed upgradient } \\
\text { levels }\end{array}$ & $\begin{array}{l}\text { Contaminants in } \\
\text { nutritional range }\end{array}$ & $\begin{array}{l}\text { Contaminants of low } \\
\text { toxicity and/or high } \\
\text { dietary range }\end{array}$ & $\begin{array}{l}\text { Contaminants of } \\
\text { potential } \\
\text { concern }\end{array}$ \\
\hline Ammonium & & $x$ & \\
\hline Arsenic & & & $x$ \\
\hline Calcium & $x$ & & \\
\hline Cadmium & & & $x$ \\
\hline Chloride & $x$ & & \\
\hline Cobalt & & & $x$ \\
\hline Copper & & $x$ & \\
\hline Fluoride & & & $x$ \\
\hline Iron & & & $\mathrm{x}$ \\
\hline Manganese & & & $x$ \\
\hline Molybdenum & & & $x$ \\
\hline Nickel & & & $x$ \\
\hline Potassium & $x$ & & \\
\hline Radium-226 & & & $x$ \\
\hline Sodium & & $x$ & \\
\hline Sulfate & & & $x$ \\
\hline Uranium & & & $x$ \\
\hline Vanadium & & & $x$ \\
\hline Zinc & & & $x$ \\
\hline
\end{tabular}


Table 3.9 Aqueous species of contaminants of potential concern in the alluvial aquifer at the Grand Junction, Colorado, site

\begin{tabular}{|c|c|c|c|c|}
\hline $\begin{array}{c}\text { Contaminant } \\
\text { of potential concern }\end{array}$ & Nomenclature & $\begin{array}{l}\text { Aqueous } \\
\text { species }\end{array}$ & $\begin{array}{l}\text { Valence } \\
\text { state }\end{array}$ & $\begin{array}{c}\text { Molar } \\
\text { percent }\end{array}$ \\
\hline \multirow[t]{2}{*}{ Arsenic } & Arsenate & $\mathrm{HAsO}_{4}{ }^{2-}$ & As $(V)$ & 80 \\
\hline & Arsenate & $\mathrm{H}_{2} \mathrm{AsO}_{4}^{-}$ & As(V) & 20 \\
\hline \multirow[t]{7}{*}{ Cadmium } & Cadmium & $\mathrm{Cd}^{2+}$ & $\mathrm{Cd}(I I)$ & 28 \\
\hline & Cadmium sulfate & $\mathrm{CdSO}_{4 A Q}$ & $\mathrm{Cd}(\mathrm{II})$ & 24 \\
\hline & Cadmium chloride & $\mathrm{CdCl}^{+}$ & $\mathrm{Cd}(\mathrm{II})$ & 21 \\
\hline & Cadmium bicarbonate & $\mathrm{CdHCO}_{3}^{+}$ & $C d(I I)$ & 9 \\
\hline & Cadmium carbonate & $\mathrm{CdCO}_{3 A Q}$ & Cd(III) & 8 \\
\hline & Cadmium disulfate & $\mathrm{Cd}\left(\mathrm{SO}_{4}\right)_{2}^{2-}$ & $\mathrm{Cd}(\mathrm{II})$ & 9 \\
\hline & Cadmium dichloride & $\mathrm{CdCl}_{2 A Q}$ & $\mathrm{Cd}(\mathrm{II})$ & 1 \\
\hline \multirow[t]{2}{*}{ Cobalt $^{b}$} & Cobalt carbonate $^{b}$ & $\mathrm{CoCO}_{3 A O}$ & Co(II) & 80 \\
\hline & Cobalt $^{b}$ & $\mathrm{Co}^{2+}$ & Co(II) & 20 \\
\hline \multirow[t]{3}{*}{ Fluoride } & Fluoride & $F$ & $F(I)$ & 86 \\
\hline & Magnesium fluoride & $\mathrm{MgF}^{+}$ & $F(I)$ & 14 \\
\hline & Calcium fluoride & $\mathrm{CaF}^{+}$ & $F(I)$ & 0 \\
\hline \multirow[t]{2}{*}{ Iron } & Ferrous iron & $\mathrm{Fe}^{2+}$ & $\mathrm{Fe}(I I)$ & 66 \\
\hline & Ferrous sulfate & $\mathrm{FeSO}_{4 \mathrm{AO}}$ & $\mathrm{Fe}(I I)$ & 32 \\
\hline \multirow[t]{4}{*}{ Manganese } & Manganese & $\mathrm{Mn}^{2+}$ & $M n(I I)$ & 61 \\
\hline & Manganese sulfate & $\mathrm{MnSO}_{4 A O}$ & $M n(I I)$ & 33 \\
\hline & Manganese bicarbonate & $\mathrm{MnHCO}_{3}{ }^{+}$ & Mn(II) & 4 \\
\hline & Manganese chloride & $\mathrm{MnCl}^{+}$ & $\mathrm{Mn}$ (II) & 2 \\
\hline Molybdenum $^{c}$ & Molybdate & $\mathrm{MoO}_{4}{ }^{2-}$ & Mo(VI) & 100 \\
\hline \multirow[t]{5}{*}{ Nickel } & Nickel carbonate & $\mathrm{NiCO}_{3 A Q}$ & $\mathrm{Ni}(I I)$ & 79 \\
\hline & Nickel & $\mathrm{Ni}^{2+}$ & $\mathrm{Ni}(I I)$ & 10 \\
\hline & Nickel sulfate & $\mathrm{NiSO}_{4 \mathrm{AQ}}$ & $\mathrm{Ni}(I I)$ & 5 \\
\hline & Nickel bicarbonate & $\mathrm{NiHCO}_{3}{ }^{+}$ & $\mathrm{Ni}(I I)$ & 4 \\
\hline & Nickel dicarbonate & $\mathrm{Ni}\left(\mathrm{CO}_{3}\right)_{2}{ }^{2-}$ & $\mathrm{Ni}(I I)$ & 1 \\
\hline
\end{tabular}


Table 3.9 Aqueous species of contaminants of potential concern in the alluvial aquifer at the Grand Junction, Colorado, site (Concluded)

\begin{tabular}{|c|c|c|c|c|}
\hline $\begin{array}{c}\text { Contaminant } \\
\text { of potential concern }\end{array}$ & Nomenclature & $\begin{array}{l}\text { Aqueous } \\
\text { species }\end{array}$ & $\begin{array}{l}\text { Valence } \\
\text { state }\end{array}$ & $\begin{array}{l}\text { Molar } \\
\text { percent }\end{array}$ \\
\hline \multirow[t]{5}{*}{ Sulfate } & Sulfate & $\mathrm{SO}_{4}{ }^{2-}$ & S(VI) & 95 \\
\hline & Calcium sulfate & $\mathrm{CaSO}_{4 \mathrm{AO}}$ & $S(V I)$ & 1 \\
\hline & Magnesium sulfate & $\mathrm{MgSO}_{4 A O}$ & $S(V I)$ & 14 \\
\hline & Sodium sulfate & $\mathrm{NaSO}_{4}^{-}$ & S(VI) & 5 \\
\hline & Ammonium sulfate & $\mathrm{NH}_{4} \mathrm{SO}_{4}^{-}$ & S(VI) & 4 \\
\hline \multirow[t]{2}{*}{ Uranium } & Uranyl tricarbonate & $\mathrm{UO}_{2}\left(\mathrm{CO}_{3}\right)_{3}{ }^{4-}$ & U(VI) & 86 \\
\hline & Uranyl dicarbonate & $\mathrm{UO}_{2}\left(\mathrm{CO}_{3}\right)_{2}{ }^{2-}$ & U(VI) & 13 \\
\hline \multirow[t]{8}{*}{ Vanadium } & Vanadium trihydroxide & $\mathrm{V}(\mathrm{OH})_{3}^{+}$ & V(IV) & 86 \\
\hline & Vanadium oxide & $\mathrm{VO}^{2+}$ & $V(I V)$ & 8 \\
\hline & Vanadium oxide & $\mathrm{H}_{2} \mathrm{~V}_{2} \mathrm{O}_{4}^{2+}$ & V(IV) & 0 \\
\hline & Vanadium sulfate & $\mathrm{VOSO}_{4 A Q}$ & V(IV) & 5 \\
\hline & Vanadium fluoride & VOF $^{+}$ & $V(I V)$ & 1 \\
\hline & Vanadate & $\mathrm{HV}_{2} \mathrm{O}_{7}{ }^{3-}$ & $V(V)$ & 81 \\
\hline & Vanadate & $\mathrm{H}_{2} \mathrm{VO}_{4}^{-}$ & $V(V)$ & 16 \\
\hline & Vanadate & $\mathrm{HVO}_{4}{ }^{2-}$ & $V(V)$ & 3 \\
\hline \multirow[t]{6}{*}{ Zinc } & Zinc & $\mathrm{Zn}^{2+}$ & $\mathrm{Zn}(I I)$ & 38 \\
\hline & Zinc sulfate & $\mathrm{ZnSO}_{4 A O}$ & $\mathrm{Zn}(I I)$ & 28 \\
\hline & Zinc bicarbonate & $\mathrm{ZnHCO}_{3}^{+}$ & $\mathrm{Zn}(I I)$ & 13 \\
\hline & Zinc carbonate & $\mathrm{ZnCO}_{3 A Q}$ & $\mathrm{Zn}(I I)$ & 9 \\
\hline & Zinc disulfate & $\mathrm{Zn}\left(\mathrm{SO}_{4}\right)_{2}^{2-}$ & $\mathrm{Zn}(I I)$ & 8 \\
\hline & Zinc dicarbonate & $\mathrm{Zn}\left(\mathrm{CO}_{3}\right)_{2}^{2-}$ & $\mathrm{Zn}(I I)$ & 2 \\
\hline
\end{tabular}

around water quality analysis from well GRJ-01-0586 (1989 sampling round) and maximum concentrations of contaminants of potential concern (excluding sulfate) (Table 3.4) were used as input for the model. Aqueous species were calculated using the geochemical code MINTEOA2/PRODEFA2 (Allison et al., 1991). Select speciation information was taken from Brookins (1988).

bstimated from Eh-pH diagram (Brookins, 1988) and the similar behavior of nickel and cobalt in an aqueous environment.

c Estimated from Eh-pH diagram (Brookins, 1988). 
All of the metallic and semimetallic contaminants are $\mathrm{pH}$-sensitive and can be solubilized and transported by ground water under acidic conditions. Some of these metals (e.g., zinc, cadmium, and nickel) are relatively insensitive to aqueous Eh conditions but form soluble cationic species under acidic ground water conditions. These contaminants will generally reprecipitate (e.g., as hydroxide or carbonate compounds) or be readsorbed by the aquifer matrix once the $\mathrm{pH}$ and/or alkalinity of the affected water is increased to near upgradient levels by reacting with the aquifer matrix or by mixing with uncontaminated water.

Other metals and metalloids (e.g., iron, manganese, arsenic, uranium, and vanadium) are sensitive to $\mathrm{pH}$ and Eh conditions. Once adsorbed or precipitated, they can be remobilized by a significant change in the ambient state of either of these important ground water and aquifer parameters. At the Grand Junction site, the dominant on-site factor controlling these contaminants appears to be the effects of contaminant-rich acid tailings leachate.

The metallic contaminants of potential concern listed in Table 3.8 can be placed into the following groups based on similar fate and transport characteristics.

Iron and manganese - Iron and manganese were solubilized from the tailings and subpile aquifer matrix by the acidic tailings pore solutions that interacted with them. Tailings pore fluids were strongly oxidizing and the conditions in the shallow ground water on-site affected by tailings pore fluids are probably relatively oxidizing. Under oxidizing conditions, iron and manganese will hydrolyze and precipitate as oxyhydroxides once the $\mathrm{pH}$ approaches neutral values. Although this process can occur at lower values of $\mathrm{pH}(5.0$ to about 6.5), the kinetics of oxidation and hydrolysis are slower. The oxidation of manganese in particular is very sensitive to $\mathrm{pH}$, and this element can persist in solution as $\mathrm{Mn}^{2+}$ under some what oxidizing ground water conditions if the $\mathrm{pH}$ is much below about 7.5 to 8.0 .

Nickel, cobalt, and zinc - The precipitation of iron and manganese as hydroxides, as acidity is neutralized by reacting with the aquifer matrix and by mixing with alkaline ground water, can be of critical importance for the fate of many other contaminant trace elements. Iron and manganese hydroxides have a high affinity for many trace constituents, and the precipitation of these hydroxides can sweep other potentially toxic metals such as cobalt, nickel, thorium, and zinc from ground water. Under the typical $\mathrm{pH}$ range of 6.0 to 8.0 observed for the alkaline (alkalinity of near $400 \mathrm{mg} / \mathrm{L} \mathrm{CaCO}_{3}$ ) ground water in the alluvial aquifer, cobalt, nickel, and zinc should rapidly approach upgradient levels in downgradient ground water.

Cadmium - Cadmium will be rapidly removed by the precipitation of octavite $\left(\mathrm{CdCO}_{3}\right)$ and by hydrolysis reactions as the low $\mathrm{pH}$ of the tailings leachate is neutralized by alkaline ground water and calcite $\left(\mathrm{CaCO}_{3}\right)$ in the aquifer matrix. Dilution with upgradient water will produce cadmium concentrations in downgradient ground water that are typically below detection limits. Elevated 
levels of cadmium should be restricted to the areas underneath or immediately adjacent to the former tailings pile.

Radium - Radium solubility and mobility at the Grand Junction site should be extremely low. Radium forms a highly insoluble sulfate compound and commonly co-precipitates with barite $\left(\mathrm{BaSO}_{4}\right)$. Radium also has a high adsorption affinity for clays and for iron and manganese hydroxides.

Arsenic, uranium, molybdenum, and vanadium - Some other metallic contaminants of potential concern such as arsenic, uranium, molybdenum, and vanadium commonly form stable anionic species under near-neutral to alkaline conditions, and they will not precipitate immediately or be completely swept by the precipitation of iron and manganese hydroxides. These contaminants can be transported for significant distances under oxidizing, near-neutral to alkaline ground water conditions before they are eventually absorbed by the matrix and/or diluted to upgradient levels by mixing with uncontaminated ground water.

\section{Fate and transport of nonmetallic contaminants}

As with the metallic contaminants, the fate and transport of nonmetallic contaminants also varies in the aquifer. Fluoride and sulfate are the only two nonmetallic contaminants of potential concern identified for the Grand Junction site. The fate and transport characteristics of these contaminants are discussed below.

Fluoride - Fluoride is elevated relative to upgradient levels in the tailings leachate and leachate-contaminated ground water at the Grand Junction site (Tables 3.4 and 3.6). Geochemical modeling of upgradient ground waters, plume-affected ground water, and acidic tailings leachate indicated that all of these waters approached or slightly exceeded saturation with fluorite $\left(\mathrm{CaF}_{2}\right)$. This suggests that the upper limit on fluoride concentrations in the alkaline, plumecontaminated on-site and near-downgradient ground water will be set by the precipitation of fluorite. As the plume migrates farther downgradient, dilution with river water and adsorption of fluoride on aquifer sediments could reduce the concentration of this constituent below levels required to maintain equilibrium with fluorite.

Sulfate - Adsorption reactions are not likely to have a significant effect on the sulfate concentrations in the shallow ground water because of the relatively high concentrations involved and the gypsum-rich mineralogy of the sediments. There is some evidence that gypsum precipitation predominantly is reducing sulfate concentrations, possibly because the shallow ground water in and around the former tailings pile area is oversaturated with gypsum. Since the tailings have been removed, the ground water sulfate concentrations in these areas should decrease. Eventually, as sulfate levels drop below gypsum saturation, the gypsum that has precipitated previously will begin to redissolve. The dissolution of gypsum will buffer the sulfate concentrations at fairly high levels at the site until the gypsum supply is exhausted. At this point, sulfate 
concentrations at the site should equal concentrations that are observed in upgradient wells.

\subsection{HUMAN HEALTH RISK SUMMARY}

The BLRA for the Grand Junction site evaluated the potential for adverse human health effects to occur if people were exposed to the contaminated ground water at the site (DOE, 1995b).

\subsubsection{Ground water and land use}

The Grand Junction site is located in a primarily urbanized area, with commercial, industrial, and residential development nearby. To the north, northeast, and west of the site, residences have been replaced with commercial and industrial establishments. Some residences are interspersed with commercial properties west of the site. The location of the Denver and Rio Grande Western Railroad makes the area near the site desirable for industrial development. Currently, the site and the area surrounding the site are zoned industrial. Thus, the probability of the site land or the land near the site being used for residences or agricultural purposes is highly unlikely.

Ground water is not used in the Grand Junction area because of the naturally poor water quality and the readily available alternative water supplies. In the vicinity of the Grand Junction site and the majority of the Grand Valley area, municipal and industrial water needs are supplied by surface water. Most of the surface water for the Grand Valley area originates from the Grand Mesa.

Additionally, water use surveys indicate there are no known current users of affected ground water in the alluvial aquifer at or near the site (DOE 1995b). Consequently, there is a low potential for shallow ground water to be used in the future. Nonetheless, the risk assessment evaluated the hypothetical future use of ground water for domestic purposes. Domestic ground water use is defined in this SOWP as ground water used for drinking, cooking, bathing, and other purposes such as irrigating gardens and watering livestock.

\subsubsection{Methods}

Contaminants of potential concern are contaminants that could cause adverse health effects if taken into the body. Contaminants of potential concern were identified for the Grand Junction site by evaluating site-related data using the procedure discussed in Section 3.6.5. The contaminants of potential concern evaluated quantitatively in the BLRA include arsenic, cadmium, cobalt, fluoride, iron, manganese, molybdenum, nickel, radium-226, sulfate, uranium, vanadium, and zinc (DOE, 1995b). Of these contaminants, arsenic, uranium, and radium226 are known human carcinogens.

Four potential routes of exposure were evaluated: ingestion of ground water as drinking water, dermal contact with ground water while bathing, ingestion of garden produce irrigated with contaminated ground water, and ingestion of fish 
that inhabit the Colorado River. Exposure doses were calculated for these exposure routes (except for the fish ingestion exposure route) by using the maximum detected concentration from the most contaminated plume wells. The concentrations in fish were calculated by using surface water quality data.

A ratio of the exposure dose from each exposure route relative to the exposure dose from ground water ingestion (as drinking water) was calculated. The results indicated that adverse toxic responses to exposure to contaminants from routes other than drinking water would not be expected. Therefore, it was determined that ingesting ground water as drinking water would be the primary contributor to total exposure, relative to all other exposure routes. Consequently, the use of ground water as drinking water was evaluated probabilistically.

Currently, no one uses the contaminated ground water. Furthermore, use of the contaminated ground water in the future is unlikely because of the water's unpleasant taste and odor, historical knowledge of poor water quality, and the availability of an alternative water supply. However, the BLRA (DOE, 1995b) evaluated the use of a hypothetical well for drinking water at some point in time in the future.

Probability distributions for contaminant concentrations and exposure variables (that is, body weight, drinking water ingestion rates, exposure frequency, and exposure duration) were integrated to estimate the range of contaminant exposure doses people could ingest from a hypothetical well constructed in the most contaminated portion of the plume. Children (1 to 10 years) were evaluated for these exposure scenarios because children consume more water on a body-weight basis than adults and consequently ingest a higher contaminant dose than aduits. However, when a subpopulation was identified as more sensitive to exposure to certain contaminants, that population was evaluated. At the Grand Junction site, infants have been identified as the population most sensitive to sulfate. Adults were evaluated for the carcinogenic effects of arsenic, uranium, and radium-226 for an exposure duration of 70 years. The estimated range of exposure doses from contaminants of potential concern a person could ingest through drinking water were compared to toxic effects these contaminant levels could cause.

\subsubsection{Potential impacts from contaminated ground water}

As stated previously, no one currently uses the ground water contaminated by former uranium processing activities and, therefore, no human health risks have resulted from the use of the water. However, the assessment of a hypothetical well constructed in the future indicated that certain health risks could occur if the contaminated ground water were ingested as drinking water. It should be noted that only the people who drink all their water from the most contaminated portion of the plume could experience the adverse health effects discussed in this document. The risk assessment evaluation provides the upper limit of 
possible risks; therefore, this future scenario evaluation probably overestimates real risks.

The most severe noncarcinogenic health effects could occur due to the water's sulfate and manganese content and to a lesser extent fluoride, vanadium, cadmium, iron, arsenic, molybdenum, zinc, and nickel. Short-term effects from sulfate exposure would be severe diarrhea quickly leading to dehydration, especially in infants. Manganese exposure could cause memory loss, irritability, muscle rigidity, and, at higher exposures, Parkinson's-like effects.

Long-term fluoride exposure could result in dental damage (mottling) in children. Additionally, at higher doses and over a long time (10-20 years), a crippling skeletal disease could develop in adults. Vanadium exposure could cause sudden drops in cholesterol levels and cramps. A distinguishing feature of vanadium exposure is the development of a green tongue. Long-term cadmium exposure could result in an increase in proteins detected in the urine indicating kidney dysfunction. Long-term iron exposures could cause pigmentation of the skin and liver dysfunction, which could lead to cirrhosis of the liver and/or diabetes. Arsenic exposure could cause arterial thickening and skin disorders with long-term exposure. Molybdenum exposure could cause mineral imbalances with a loss of copper from the body causing anemia with long-term exposure. Zinc exposure could cause a decreased ability for copper to be absorbed resulting in a breakdown of biological processes in the body. People exposed to nickel could develop allergic dermatitis.

Carcinogenic risk estimates were calculated for the radionuclides uranium and radium-226. The increased individual excess lifetime cancer risk from exposure to uranium was estimated to be $3 \times 10^{-4}$, or three chances in 10,000 of developing cancer; for radium-226 the cancer risk was estimated to be $2 \times 10^{-4}$, or two chances in 10,000 of developing cancer. The increased individual lifetime cancer risk from exposure to arsenic was estimated to be $4 \times 10^{-3}$, or four chances in 1000 of developing cancer. The estimated risk levels for arsenic, uranium, and radium-226 exceed the EPA-recommended risk level for carcinogens of $1 \times 10^{-4}$, or one chance in 10,000 of developing cancer (40 CFR Part 300).

If exposure doses from the other exposure routes (dermal contact with ground water or eating garden produce or fish) are added to the exposure from the drinking water exposure route, the exposure concentrations would not be expected to substantially increase the potential for adverse health effects. Additionally, adverse health effects would not be expected from these exposure routes if they were the only routes of exposure.

\subsubsection{Potential impacts from background ground water}

Background ground water quality is discussed in Section 3.6.1. Water quality data from upgradient wells 745 and 746 were used to evaluate background ground water quality in the BLRA. As previously discussed, there is some 
uncertainty related to using these wells for characterizing background ground water quality. Therefore, regional ground water quality data are also used to assess background conditions in this SOWP. This section presents an evaluation of background ground water quality from a human health-based perspective to determine if background ground water would be suitable to ingest as drinking water.

\section{Comparison to federal standards}

Ground water quality data from upgradient wells 745 and 746 and USGS regional ground water data are compared to federal water quality standards in Table 3.10. As seen in this table, levels of sulfate, TDS, manganese, iron, fluoride, and chloride exceed the national secondary drinking water levels (40 CFR Part 143) in regional ground water. These levels are based on aesthetics of the water such as taste and odor. This comparison shows that upgradient and regional background ground water is considered unpalatable as drinking water. Also, since the regional ground water exhibits maximum TDS concentrations of greater than $10,000 \mathrm{mg} / \mathrm{L}$, it may be classified as a limiteduse aquifer under 40 CFR Part 192, as amended by 60 FR 2854.

Selenium and uranium concentrations in background ground water exceed MCLs and the national primary drinking water level for selenium (40 CFR Part 141) and the proposed national primary drinking water level for uranium (56 FR 33050). Uranium concentrations have been detected in regional ground water at levels as high as at the Grand Junction site $(0.45 \mathrm{mg} / \mathrm{L})$. Selenium has been detected in regional ground water at concentrations more than five times higher than at the site.

\subsubsection{Potential public health impacts from drinking background ground water}

Potential public health impacts from using background ground water as drinking water are assessed by calculating point-exposure doses and comparing the exposure doses to toxic effect levels observed for the contaminants of potential concern.

In the BLRA (DOE, 1995b), exposure doses are calculated for all contaminants statistically detected above background at the site. Maximum concentrations of the contaminants in the upgradient wells 745 or 746 and the regional background wells are used in these calculations (see Table 3.10). Selenium is also evaluated because it is detected in high concentrations in regional ground water relative to the concentrations found at the site. The potential receptors assessed were children, infants, and adults. The exposure dose calculations, which followed UMTRA Ground Water Project methodology (DOE, 1994a), used the following drinking water exposure variables:

- A 1-to 10-year-old child with an average weight of 22 kilograms $(\mathrm{kg})$ and an average ingestion rate of 0.7 liters per day (L/day) of ground water for 350 days per year for 10 years. 
Table 3.10 Comparison of concentrations of contaminants in the Grand Junction, Colorado, site vicinity to federal standards

\begin{tabular}{|c|c|c|c|c|c|}
\hline Contaminant & $\begin{array}{l}\text { Upgradient range } \\
\text { (min - } \max )\end{array}$ & $\begin{array}{l}\text { Regional range } \\
\text { (min - max })\end{array}$ & NSDWR $^{c}$ & NPDWR $^{d}$ & UMTRA $^{\circ}$ \\
\hline Ammonium & ND -0.6 & ND -3 & - & - & - \\
\hline Arsenic & $0.001-0.04$ & ND - 0.002 & - & 0.05 & 0.05 \\
\hline Calcium & $325-595$ & $98-610$ & - & - & - \\
\hline Cadmium & ND - 0.04 & ND -0.002 & - & 0.005 & 0.01 \\
\hline Chloride & $306-2400$ & $140-2500$ & 250 & - & - \\
\hline Cobalt & ND - 0.01 & NA & $\cdot$ & - & - \\
\hline Copper & $0.003-0.03$ & ND -0.016 & 1 & - & - \\
\hline Fluoride & $0.6-1.7$ & $0.2-3.1$ & 2 & 4 & - \\
\hline Iron & ND -2.2 & ND -0.5 & 0.3 & - & - \\
\hline Manganese & $0.9-2.3$ & ND - 0.93 & 0.05 & - & - \\
\hline Molybdenum & $0.01-0.23$ & ND -0.015 & - & - & 0.1 \\
\hline Nickel & ND - 0.12 & NA & - & 0.1 & - \\
\hline Potassium & $4.2-12$ & $2.1-19$ & - & - & - \\
\hline Radium-226 & $0-2.3$ & NA & - & $20^{f}$ & $5^{9}$ \\
\hline Selenium & ND - 0.19 & ND -1.3 & - & 0.05 & 0.01 \\
\hline Sodium & $345-910$ & $310-3200$ & - & - & - \\
\hline Sulfate & $1450-11,000$ & $2000-9700$ & 250 & - & - \\
\hline TDS & $3000-7200$ & $3300-16,100$ & 500 & - & - \\
\hline Uranium & $0.017-0.072$ & $0.0085-0.45$ & - & $0.02^{f}$ & 0.044 \\
\hline Vanadium & ND -0.11 & $0.003-0.17$ & - & - & - \\
\hline Zinc & ND - 1.0 & NA & 5 & - & - \\
\hline
\end{tabular}

Concentrations in milligrams per liter except for radium-226, which is picocuries per liter.

ND - not detected at the method detection limit.

NA - not analyzed.

NSDWR = national secondary drinking water regulations.

NPDWR - national primary drinking water regulations.

a Range from upgradient background wells GRJ-01-0745 and GRJ-01-0746.

${ }^{b}$ Range from regional background data near the Grand Junction site (Butler et al., 1994).

' 40 CFR Part 143.

' 40 CFR Part 141.

- 40 CFR Part 192, as amended by 60 FR 2854.

'Proposed NPDWR maximum contaminant level (56 FR 33050).

- UMTRA MCL is $5 \mathrm{pCi} / \mathrm{L}$ for radium-226 and radium-228 combined. 
- Since infants are more sensitive to sulfate exposure, sulfate is evaluated for an infant weighing an average of $4 \mathrm{~kg}$ with an average ingestion rate of 0.64 L/day of ground water for 350 days per year for 1 year.

- Arsenic is evaluated for an adult weighing $70 \mathrm{~kg}$ with an average ingestion rate of $2 \mathrm{~L} /$ day of ground water for 350 days per year for 30 years. These same parameters are used to evaluate radionuclides; however, body weight was not factored into the calculations because it is relatively insignificant when calculating exposure doses for radionuclides.

Table 3.11 presents the point-exposure dose calculation results. The doses are expressed in milligrams per kilogram of body weight per day. A graphic summary of the exposure doses where toxic effects are likely to occur are also presented in Appendix B.

The results of the assessment indicate that, if the regional ground water were ingested as drinking water, sulfate, selenium, manganese, sodium, chloride, and fluoride have the potential to cause adverse health effects. Likewise, from the upgradient wells 745 or 746 , sulfate, manganese, and chloride have the potential to cause adverse health effects.

The individual excess lifetime cancer risk calculated for the upgradient background ground water, as represented by wells 745 and 746 , shows that the cancer risk for arsenic $\left(8 \times 10^{-4}\right)$ exceeds the EPA-recommended risk level of $1 \times 10^{-4}$ (40 CFR Part 300). The maximum detected concentration of uranium $(0.45 \mathrm{mg} / \mathrm{L})$ detected in the regional background ground water is the same as the maximum detected value of uranium detected at the site. Therefore, the incremental cancer risk calculated for uranium for the regional background ground water and the plume water is the same $\left(3 \times 10^{-4}\right)$, which also exceeds the EPA-recommended risk level.

The conclusion of the point exposure dose evaluation and comparison to standards of upgradient and regional background ground waters substantiates that the background ground water in the Grand Junction area is poor. That is, drinking the background ground water could cause adverse health effects. In addition, the water is unpalatable due to high levels of sulfate, TDS, manganese, iron, fluoride, and chloride.

\subsection{ECOLOGICAL RISK SUMMARY}

This section summarizes the ecological screening evaluation performed in the BLRA for the Grand Junction site (DOE, 1995b). The methodology used to evaluate the ecological risk at the site followed EPA guidance (EPA, 1989). In late 1994, subsequent to preparation of the BLRA, eight ponds were constructed in the floodplain of the Colorado River over the Grand Junction site contaminant plume (Figure 3.16). These ponds were constructed as part of wetland mitigation for the Grand Junction surface remediation project. High 
Table 3.11 Point exposure dose and cancer risk estimates for background ground water ingestion pathway, Grand Junction, Colorado, site

\begin{tabular}{|c|c|c|c|c|c|c|c|}
\hline \multirow[b]{2}{*}{ Contaminant } & \multicolumn{2}{|c|}{$\begin{array}{l}\text { Maximum contaminant } \\
\text { concentration : }\end{array}$} & \multicolumn{2}{|c|}{ Exposure dose } & \multirow[b]{2}{*}{ CSF $^{\mathrm{C}}$} & \multicolumn{2}{|c|}{ Cancer risk ${ }^{\mathrm{d}}$} \\
\hline & Upgradient & $\begin{array}{c}\text { Regional } \\
\text { background }\end{array}$ & Upgradient & $\begin{array}{l}\text { Regional } \\
\text { background }\end{array}$ & & Upgradient & $\begin{array}{c}\text { Regional } \\
\text { background }\end{array}$ \\
\hline \multicolumn{8}{|c|}{ Carcinogenic effects - adult } \\
\hline Arsenic & 0.04 & 0.002 & $5 E-04$ & $2 E-05$ & 1.8 & $8 E-04$ & $4 E-05$ \\
\hline Radium-226 & 2.3 & NA & $5 E+04$ & - & $2.96 \mathrm{E}-10$ & $1 E-05$ & - \\
\hline Uranium & 49 & 309 & $1 E+06$ & $6 \mathrm{E}+06$ & $5.32 \mathrm{E}-11$ & $5 E-05$ & $3 E-04$ \\
\hline \multicolumn{8}{|c|}{ Noncarcinogenic effects - child } \\
\hline Ammonium & 0.6 & 3 & 0.02 & 0.09 & & & \\
\hline Arsenic & 0.04 & 0.002 & 0.001 & 0.0001 & & & \\
\hline Calcium & 595 & 610 & 18 & 19 & & & \\
\hline Cadmium & 0.04 & 0.002 & 0.001 & 0.0001 & & & \\
\hline Chloride & 2400 & 2500 & 73 & 76 & & & \\
\hline Cobalt & 0.01 & NA & 0.0003 & - & & & \\
\hline Copper & 0.03 & 0.016 & 0.001 & 0.0005 & & & \\
\hline Fluoride & 1.7 & 3.1 & 0.05 & 0.09 & & & \\
\hline Iron & 2.2 & 0.5 & 0.07 & 0.02 & & & \\
\hline Manganese & 2.3 & 0.93 & 0.07 & 0.03 & & & \\
\hline Molybdenum & 0.23 & 0.015 & 0.01 & 0.0005 & & & \\
\hline Nickel & 0.12 & NA & 0.004 & - & & & \\
\hline Potassium & 12 & 19 & 0.37 & 0.58 & & & \\
\hline Selenium & 0.19 & 1.3 & 0.01 & 0.04 & & & \\
\hline Sodium & 910 & 3200 & 28 & 98 & & & \\
\hline Sulfate & 11,000 & 9700 & 336 & 296 & & & \\
\hline Uranium & 0.072 & 0.45 & 0.002 & 0.01 & & & \\
\hline Vanadium & 0.11 & 0.17 & 0.003 & 0.01 & & & \\
\hline Zinc & 1.0 & NA & 0.03 & - & & & \\
\hline \multicolumn{8}{|c|}{ Noncarcinogenic effects - infant } \\
\hline Sulfate & 11,000 & 9700 & 1700 & 1500 & & & \\
\hline
\end{tabular}

Note: Concentrations are reported in milligrams per liter; when radium-226 and uranium are evaluated for carcinogenic effects, values are in picocuries per liter.

NA - not analyzed.

CSF - cancer slope factor.

- Maximum concentrations from Table 3.10. Upgradient concentrations are from wells 745 and 746; regional background concentrations are from Butler et al. (1994).

- Exposure doses in milligrams per kilogram of body weight per day.

c The CSF is used to estimate an upper-bound probability of an individual developing cancer as a result of a lifetime of exposure to a particular level of a potential carcinogen.

- The cancer risk is calculated by multiplying the exposure dose by the CSF. 
water during the spring of 1995 flooded the ponds and filled most of them with silt. The ecological risk associated with these ponds also is evaluated in this SOWP.

\subsubsection{Methods}

The ecological evaluation of the Grand Junction site was a screening-level assessment of the risks associated with the potential exposure of terrestrial and aquatic biological communities to contaminated ground water or to media potentially affected by ground water such as surface water and sediment. Contaminant concentrations detected in environmental media were compared to aquatic life criteria and sediment, vegetation, wildlife, livestock watering, and crop irrigation guidelines to determine if the contaminants of potential concern pose a risk to ecological, livestock, and agricultural receptors.

The screening-level ecological assessment provided an analysis of surface water and sediments of the Colorado River that have the potential to be impacted by contaminated ground water from the Grand Junction site. In addition, this assessment addressed the potential impacts to plants that may root in the contaminated ground water and a hypothetical future scenario of creating a stock pond or using contaminated ground water for crop irrigation.

Ecological contaminants of potential concern were determined for ground water, surface water, and sediments. For ground water, the contaminants of potential concern are those contaminants that statistically exceeded background levels (Table 3.8). Surface water contaminants of potential concern were selected by comparing downstream concentrations to upstream concentrations.

Ammonium, copper, iron, radium-226, uranium, and vanadium were selected as contaminants of potential concern. Only one sediment sampling round was available for evaluation. The constituents evaluated include molybdenum, selenium, strontium, sulfate, and uranium. The contaminants of potential concern were compared to the appropriate criteria or guidance values protective of aquatic and terrestrial biological communities and agricultural resources.

Contaminants of potential concern in the wetlands mitigation ponds were determined by comparing concentration levels to ground water quality in upgradient monitor wells. Section 3.6 provides a discussion of the methods used to determine background water quality for the mitigation wetlands.

\subsubsection{Potential ecological impacts}

Potential ecological impacts were evaluated for Colorado River water, ground water, and surface water in on-site ponds.

\section{Colorado River surface water and sediments}

Even though current surface water and sediment data indicate that site-related contamination has not affected the Colorado River, the risk assessment 
nonetheless evaluated these two media for potential ecological effects. None of the contaminants of potential concern in the surface water of the Colorado River exceeded the values established for protection of aquatic life. This comparison suggests that site-related contamination has not adversely affected the water quality of the Colorado River. Likewise, data suggest that site-related contamination has not affected the sediments. Results of the ecological evaluation are consistent with the geochemical evaluation in that the surface water and sediment have not been measurably affected at the site.

\section{Contaminated ground water}

The assessment of potential impacts to plants rooting in the contaminated ground water indicated that there is likely no adverse effect from those constituents for which phytotoxic concentrations are available. Since plants that have a potential to be rooted in the contaminated ground water were not sampled, contaminants of potential concern in the plant tissue were determined by estimating the concentration in the soil in the saturated zone and using soilto-plant bioconcentration factors (DOE, 1995b). Screening-level ecological risk assessments prepared for the UMTRA Project subsequent to the Grand Junction assessment have used screening benchmark concentrations of constituents that may result in phytotoxicity to plants (Will and Suter, 1994). Since this is the method now used on the UMTRA Project to analyze for potential phytotoxic effects, the mean concentrations of constituents that were statistically above background in ground water were compared to the screening benchmarks for plants (DOE, 1995b). Exceedance of these benchmarks does not necessarily mean the water is adversely affecting plants, but it does indicate that further study is warranted. However, comparison of the screening benchmarks (Will and Suter, 1994) with the estimated concentrations in the BLRA (DOE, 1995b) indicates that cobalt and copper concentrations in ground water are just above the benchmarks while arsenic, manganese, vanadium, and zinc were 3.5 to 34 times greater than the benchmarks. This information indicates that the contaminated ground water at the Grand Junction site may potentially have an adverse effect on vegetation and that further study is warranted.

The contaminated ground water is not being used to water livestock or irrigate crops or for any other agricultural purpose. It is unlikely that these types of land uses would occur in this area in the future because of the industrial/commercial trend in the area of the site. If the ground water in the most contaminated portion of the plume were used for agricultural purposes, sulfate and TDS concentrations would preclude its use to water livestock. In addition, fluoride could cause tooth mottling in cattle and vanadium could bioaccumulate in certain organs. However, livestock could use the surface water in the river as their sole drinking water source, and adverse health effects would not be expected to occur. Future use of ground water for the continuous long-term irrigation of crops would not be suitable due to levels of cobalt, fluoride, iron, manganese, molybdenum, vanadium, and zinc. 


\section{Wetland mitigation ponds}

The water in the former wetland mitigation ponds was analyzed to determine if there was the potential for ecological effects. Table 3.7 presents the concentrations of contaminants of potential concern from the only time the ponds were sampled. In general, ponds 1 and 2 (sample locations 2000 and 2001, respectively) (Figure 3.16) had the highest contaminant concentrations. The maximum concentrations of the contaminants of potential concern were compared to aquatic life, vegetation, wildlife, livestock, and crop irrigation guidelines (EPA, 1973; Opresko et al., 1994; Suter and Mabrey, 1994; and Will and Suter, 1994). This comparison shows that, in January 1995, cadmium exceeded the chronic aquatic life benchmark of $0.0018 \mathrm{mg} / \mathrm{L}$ in ponds 1,2 , and 3 (sample location 2002); manganese exceeded the benchmark of $1.1 \mathrm{mg} / \mathrm{L}$ in ponds 2, 3, and 5 (sample location 2004); and vanadium exceeded the benchmark of $0.041 \mathrm{mg} / \mathrm{L}$ in ponds 1 and 2 . All benchmarks are from Suter and Mabrey (1994). The water quality in the ponds did not exceed any of the vegetation or wildlife benchmarks, although the concentrations of arsenic and vanadium were close to the vegetation benchmarks. In the unlikely event that water from these ponds would be used for livestock watering or crop irrigation, the concentrations of manganese, molybdenum, sulfate, and vanadium, which exceed one or both of the benchmarks, would be cause for concern.

Ponds 1 and 2 were totally filled in with silt and the volume of water in the other ponds was greatly reduced as a result of spring flooding in 1995. Based on the results of the January 1995 sampling round, it is recommended that the ponds not be replaced because the water quality was showing signs of becoming detrimental to aquatic life and rooted vegetation.

\subsection{EVALUATION OF INTERIM REMEDIAL ACTION NEEDS}

There are no known current uses of the contaminated ground water at the Grand Junction site vicinity, and no present dangers to human health or the environment have been identified. However, there is a possibility that future development in the region of contaminated ground water may result in activities such as well installation or excavation below the water table that will lead to increased risks. For example, there is a proposal to construct a pond downgradient of the site as part of a planned recreational development. This pond would likely be fed by alluvial ground water.

Current local zoning and development code requires all development to be served by the city water distribution system. The city currently does not obtain its water from local ground water sources and, due to poor local ground water quality and an adequate supply of higher quality surface water, this situation is unlikely to change in the foreseeable future. In addition, since the background ground water quality in the alluvial aquifer does not meet national primary drinking water standards (40 CFR Part 141), alluvial ground water from the site vicinity cannot be used for public drinking water supplies without being treated. Thus current institutional controls provide reasonable assurance that the 
contaminated ground water will not be used for residential, industrial, agricultural, or other municipal needs and there is no need for further controls at this time.

The surface water quality data from the wetland ponds show that contaminants in ground water feeding the ponds can be become concentrated, probably as a result of evaporation. Therefore, local agencies should implement institutional controls immediately to prevent the construction of unlined ponds or ditches in the vicinity of the contaminated ground water plume to prevent potential exposures of humans or animals to contaminated surface water. 


\subsection{GROUND WATER COMPLIANCE STRATEGY SELECTION}

This section describes the ground water compliance strategy selection process, explains the application of site-specific data to select the proposed ground water compliance strategy for the Grand Junction site, identifies data needs for the conceptual site model, and discusses handling possible deviations from the conceptual site model and the proposed strategy and contingency planning.

\subsection{COMPLIANCE STRATEGY SELECTION PROCESS}

The UMTRA Ground Water Project has developed the selection framework shown in Figure 4.1 to apply to individual sites to determine the appropriate strategy for achieving compliance with the ground water standards (40 CFR Part 192 , as amended by 60 FR 2854). This compliance strategy selection framework is identified in the UMTRA Ground Water Project draft PEIS as the proposed action (DOE, 1995a). This risk-based, decision-making framework provides for the selection of one or more of the three ground water compliance strategies defined below.

No remediation. Application of the no remediation strategy would mean that compliance with the ground water protection standards would be met without altering the ground water or cleaning it up in any way. This could be applied at sites that have no contamination above MCLs or background levels, or at sites that have contamination above MCLs or background levels but qualify for supplemental standards or ACLs.

Natural flushing. Natural flushing would allow the natural ground water movement and geochemical processes to decrease the contaminant concentrations to levels within regulatory limits within a given time period. This could be applied at sites where ground water compliance would be achieved within 100 years with the application of natural flushing, where effective monitoring and institutional controls could be maintained, and the ground water is not currently and is not projected to be a drinking water source.

Active ground water remediation. Active ground water remediation would require the application of engineered ground water remediation methods such as gradient manipulation, ground water extraction and treatment, and in situ ground water treatment to achieve compliance with the ground water protection standards.

\subsection{GRAND JUNCTION COMPLIANCE STRATEGY SELECTION}

The DOE used the selection framework described above to identify the proposed ground water compliance strategy of no remediation for the Grand Junction site. The decision steps followed are highlighted in Figure 4.1 and summarized below. 
Figure 4.1

\section{Compliance Strategy Selection Process} Grand Junction, Colorado, Site

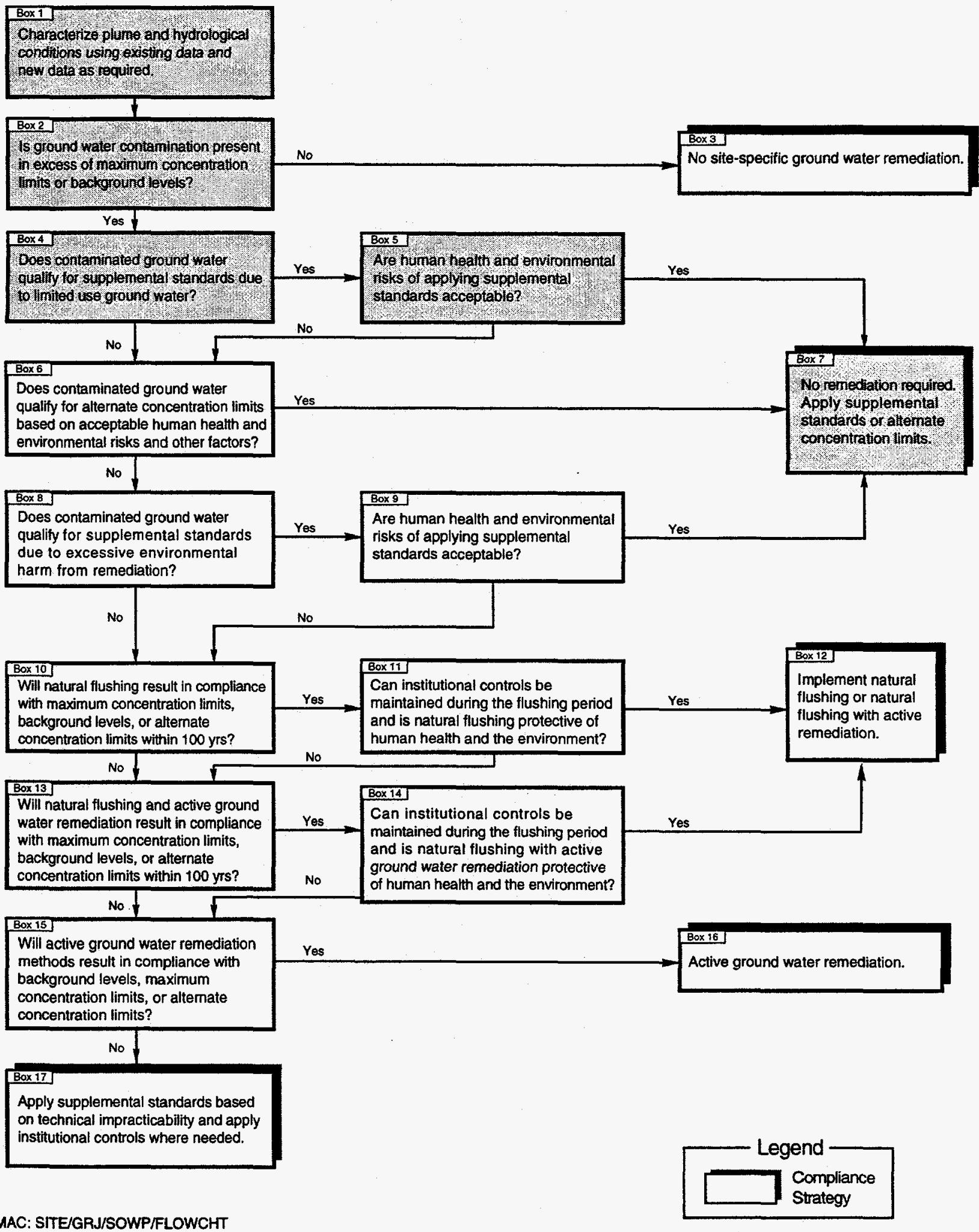

MAC: SITE/GRJ/SOWP/FLOWCHT 
The first step (box 1 ) involved compiling and analyzing both regional and sitespecific ground water characterization data. Then, site ground water quality data were compared to the ground water MCLs and background data (box 2). This comparison confirmed that the past uranium processing activities have resulted in ground water contamination that exceeds background levels or MCLs for some constituents.

The next step (box 4) evaluated whether compliance with the ground water standards could be achieved by applying supplemental standards based on the existence of limited-use ground water. The quality of the natural ground water at the Grand Junction site indicates that the contaminated aquifer likely meets the requirements for a limited-use aquifer. DOE's review of available upgradient and regional background ground water quality data revealed that TDS is in excess of $10,000 \mathrm{mg} / \mathrm{L}$ and there is widespread, ambient contamination based on naturally occurring levels of molybdenum, selenium, and uranium that exceed national primary drinking water levels or UMTRA MCLs at maximum observed concentrations (see Table 3.10). Based on a study of northwestern Colorado public water systems (DOE, 1994b), ground water sources with these kinds and levels of contaminants are not used for municipal supply as the water cannot be cleaned up using reasonably available treatment methods. Also, it appears that the USBR canal-lining project will result in further degradation of the background ground water quality.

Then, an assessment was made to determine whether the application of supplemental standards would be protective of human health and the environment (box 5). The risk assessment summaries in Sections 3.7 and 3.8 show that natural ground water quality in the area is poor and that there is no current use of the ground water. As a result of the poor water quality and local institutional controls requiring new developments to hook up to the city water distribution system, it is unlikely that ground water contaminated by past uranium processing activities will be put to beneficial use in the foreseeable future. In addition, it is unlikely that contaminated ground water discharging into the Colorado River will present unacceptable risks to the public or the environment. Therefore, it appears that, based on current information, supplemental standards would be protective of human health and the environment.

The final step identified the proposed compliance strategy of no remediation (box 7). This SOWP proposes that the ground water standards can be met by applying supplemental standards based on the criterion of limited use and that no further remediation will be required. This compliance strategy coupled with the already completed removal of the tailings from the site, poor natural water quality, and existing local institutional controls will be protective of human health and the environment. 
The no remediation ground water compliance strategy proposed for the Grand Junction site is based on the evaluation of the existing conceptual model (Section 3.3). Additional site-specific information must be collected to confirm the conceptual model, validate the application of supplemental standards based on the limited-use ground water scenario, and confirm that there are no unacceptable human health or environmental risks from ground water entering the Colorado River. The primary focus of this effort will be on the further development of our understanding of ground water flow and solute transport in the Grand Junction area and understanding of regional background ground water quality. Before the final compliance strategy is selected, data are needed to support the limited-use classification of the alluvial aquifer and the claim that the no remediation strategy will be protective of human health and the environment. Additional data collection activities will focus on regional and sitespecific hydrogeologic and geochemical conditions, impacts of lining local canals, ground water quality (including presence of organic contamination), surface water flows, impacts of ground water discharge to surface water quality, and reasonably available treatment methods for public water systems. Additionally, the DOE will need to work with state and local authorities to assess current and potential institutional control provisions.

Within the framework of the observational approach, reasonable deviations from the conceptual site model may be identified as a result of data collection and assessment. To address the potential deviations, a preliminary data needs contingency plan has been developed to deal with potential deviations and is presented in Section 5.0. This plan allows for primary data collection to support the development of the proposed compliance strategy: no remediation with supplemental standards. The contingency plan is structured so that, if in the unlikely event the aquifer does not qualify for supplemental standards or supplemental standards would not be protective of human health and the environment, primary data components of the data collection and assessment plan will still contribute useful, significant data to the most likely alternative strategy, which appears to be natural flushing based on our current understanding of the site. If at some point in the data collection and assessment process it becomes apparent to the stakeholders through evaluation of the data that an alternative compliance strategy is required, the secondary data needs component of the data collection and assessment plan will be initiated.

The hydrogeologic and geochemical data collected from the Grand Junction site and preliminary contaminant transport and ground water flow modeling indicate that natural ground water flushing appears to be an applicable alternative strategy. That is, natural ground water movement and geochemical processes will decrease the contaminant concentrations to background levels within 100 years. If further data evaluation does not support natural flushing, then active remediation would likely need to be evaluated. 
Either alternative compliance strategy must be performed in conjunction with the implementation of institutional controls on ground water usage in the vicinity of the Grand Junction site. Because these strategies involve the reduction of contaminant concentrations through time, controlling ground water usage will mitigate the immediate and long-term risks to both public health and the environment. 



\subsection{DATA COLLECTION AND ASSESSMENT PLAN}

Existing site conditions, as defined by regional studies and previous investigations conducted at the Grand Junction site, support the proposed ground water compliance strategy of no remediation by applying supplemental standards based on a limited-use aquifer. Additional site-specific and regional data collection activities are needed, however, to build a statistically significant database of regional background ground water quality for contaminants of potential concern at the site to confirm the applicability and feasibility of this proposed compliance strategy.

As addressed in Section 4.3, proposed data collection activities may result in deviations from the conceptual site model, and the adoption of an alternative compliance strategy may be required. Therefore, the DOE has developed a data collection and assessment plan, within the framework of the observational approach, that addresses the primary data needs required to support the proposed no remediation compliance strategy, as well as to support the alternative strategies of natural flushing or active remediation. The secondary data needs component of the data collection and assessment plan will only be initiated if it becomes apparent through the statistical analyses of the collected data that the aquifer will not qualify for supplemental standards or if the supplemental standards are not protective of human health and the environment.

The following sections will present a statement of primary data needs that are supportive of the no remediation strategy and those secondary data needs required to support the most likely alternative strategy of natural flushing. Also, the related data collection objectives and activities and the governing data quality objectives are briefly discussed.

Data quality objectives are quantitative and qualitative statements made to ensure that data of known and appropriate quality are obtained during an investigation. To ensure that the data gathered during investigation activities are adequate to support stakeholder decisions, a clear definition of the quality objectives and the method by which decisions will be made will be established in activity-specific work plans. Substantially more detail will be provided in activity-specific work plans submitted to the stakeholders for review and comment prior to initiation of the data collection activity.

\subsection{STATEMENT OF PRIMARY DATA NEEDS}

The DOE has identified the following primary data required to support the proposed no remediation compliance strategy based on the conceptual site model and an evaluation of the existing data.

\subsubsection{Evaluation of the Government Highline Canal}

To evaluate the long-term effect of lining the Government Highline Canal on water quality in the Grand Junction area and to support the inference that water quality will become worse over time in the alluvial aquifer after the canal is lined, the DOE should locate all available regional water quality data for areas upgradient and downgradient of a lined portion of the canal and upgradient and 
downgradient of an unlined portion of the canal. This information will be necessary to verify the expected decline in the water table elevations and the water quality (such as higher TDS concentrations) resulting from removal of the major source of recharge to the alluvial aquifer and to help quantify the source of the remaining recharge.

A detailed work plan will be developed and submitted to the stakeholders for review and comment prior to initiating this data search activity.

\subsubsection{Mass flow and dilution factors for the Colorado River}

To assess the impacts of discharge of the site ground water contaminant plume to the Colorado River, calculations will be performed to 1) determine the volume of flow of the Colorado River past the site during low-flow conditions;

2) calculate the volume of ground water discharge to the Colorado River; and

3) assess the mass per unit volume of each contaminant of potential concern that is added to the river by ground water discharge.

These calculations will use the highest levels of contaminants of potential concern observed at the site and low-flow conditions in the Colorado River to arrive at a conservative estimate of the potential (or lack thereof) to produce measurable increases above background in contaminant concentrations in the river.

\subsubsection{Collection of regional data on background ground water quality}

There are currently very few analyses of specific metals (e.g., uranium and vanadium) in regional background. To support a no remediation strategy based on limited-use ground water, it will be necessary to build a statistically significant database of analyses of regional background ground water for contaminants of potential concern at the Grand Junction site. This effort is critical to further develop the database supporting the information on widespread, ambient contamination. As part of this effort, existing wells that access regional background in the alluvial system should be identified and sampled for analysis. If few such wells can be identified, consideration should be given to installation of regional background monitor wells to fill this data gap.

If it is determined that supportive regional background data do not exist, a detailed work plan will be developed addressing the installation and sampling of regional background monitor wells and submitted to the stakeholders for review and comment.

\subsubsection{Investigation of organic contamination}

An organic solvent extraction process was used by the Climax uranium processing mill. DOE performed sampling for organic compounds at the Grand Junction site and other UMTRA Project sites in 1989 (Hill, 1989). Samples of tailings and ground water were analyzed for Appendix IX (40 CFR Part 264) 
analytes and no organic contamination was found. Even though the Appendix IX list is comprehensive and provides coverage of EPA-regulated hazardous chemicals that can be monitored in an aqueous medium, it does not provide straightforward detection $f$ kerosene or No. 2 fuel oil, which were process carrier chemicals used in large quantities at the Grand Junction site. The Appendix IX list also does not address many of the extracting solvents commonly used in uranium milling, notably di(2-ethylhexyl)phosphoric acid, tributyl phosphate, and tertiary amines in the case of the Grand Junction site.

No toxicological evaluation has been performed on kerosene or on the specific organic solvents and their breakdown products. Nonetheless, an initial toxicological review indicates that many of these chemicals and their derivatives are toxic. An organic screening will provide a first step in the determination of whether process-related organic compounds are present in ground water at the Grand Junction site and will serve as a starting point for the evaluation of the potential human health and ecological risks.

A detailed work plan will be developed and submitted to the stakeholders for review and comment prior to initiating this activity.

\subsubsection{Evaluation of available public water supply treatment capabilities}

If further investigations confirm that there is widespread, ambient contamination or poor water quality, the DOE will conduct a survey of treatment methods employed at public water systems in Grand Junction and the surrounding western Colorado area to determine if cost-effective treatment methods are reasonably available to clean up the naturally occurring ground water contaminants. The DOE will consult with state and local authorities to determine if such studies have already been conducted.

\subsection{ASSESSMENT OF DATA AND REPORTING}

Upon completion of data collection and analytical testing, data evaluation and report preparation activities will be initiated. Data evaluation activities for all data discussed above will include, but not be limited to

- Tabulation of analytical results obtained from surface water sampling, ground water sampling, and geochemical sampling.

- Calculation of risk-based analysis of contaminant data with respect to receptors.

- Synthesis of ground water level measurements, calculation of ground water elevations, and preparation of water level contour maps.

- Implementation of computer modeling and reporting of the resultant calculation of hydraulic conductivities, ground water flow path, vertical and 
horizontal gradients, ground water flow velocity, contaminant fate and transport, and surface water and ground water interactions.

- The hydrogeologic data resulting from the well tests will be used along with the estimates of rate of contaminant transport, to predict the quantity and concentrations of the contaminants being discharged to the river. Calculation of a mass balance during low-flow periods to evaluate the potential environmental impact on the river water and sediments.

Upon completion of data evaluation activities, a report will be compiled and delivered that will include a discussion of all field activities, a description of the instrumentation used, the location of the surveys, copies of all field measurement data, copies of field logs, the method of interpretation, and a summary of the results relative to the data collection objective. The results and reports will be incorporated into the SOWP (Revision 1). As the focus and overall objective of this report is to confirm or deny the applicability of the proposed compliance strategy, all recommendations, deviations, and contingencies will be identified, as will any additional data needs.

If the conclusion of Revision 1 of this SOWP is that the proposed compliance strategy will effectively bring the site into compliance and is protective of human health and the environment, a site-specific NEPA document for the proposed compliance strategy will be prepared. This document will consider the environmental impacts of both the compliance strategy itself and the activities required to implement the strategy. If it cannot be demonstrated that the proposed compliance strategy will bring the site into compliance or that the environmental impacts of implementing the strategy are not acceptable, Revision 1 of this SOWP will recommend additional steps.

\subsection{STATEMENT OF SECONDARY DATA NEEDS}

The following are the secondary data needs required to support a natural flushing or active remediation compliance strategy based on the conceptual site model and an evaluation of existing data. These data would need to be acquired only if the evaluation of the data addressing the primary needs did not support the adoption of the no remediation compliance strategy.

\subsubsection{Investigation of the current distribution of ground water contamination}

The amount and location of ground water contamination associated with the Grand Junction site is critical information if natural flushing is to be a viable strategy. There is currently no ground water quality information for most of the eastern half of the site. Figure 3.3 shows current and decommissioned monitor wells at the site. None of these wells monitored water quality on the eastern half of the site, including areas where ponds associated with uranium processing were known to exist. Part of this area contained the state-owned Colorado Tailings Repository, which stored residual radioactive materials excavated from 
vicinity properties. The installation of a monitor well network to fill this data gap should be considered.

If it is determined that this activity is required, a detailed work plan will be developed addressing the installation and sampling of monitor wells on the site and submitted to the stakeholders for review and comment.

\subsubsection{Evaluation of vicinity properties}

If natural flushing is to be a viable strategy for the site, it will be necessary to demonstrate that ground water contamination at the site will be flushed to background levels within 100 years. This will require a demonstration that vicinity properties upgradient of the site are not contributing significant contamination to background levels. Investigation of the closest upgradient property that is likely to contribute contamination to ground water (possibly the vicinity property with the largest volume of tailings or the vicinity property with the largest volume of tailings below the water table) will be required. Water quality from upgradient and downgradient of this vicinity property should be compared to determine if it is contributing contamination to the alluvial aquifer.

If it is determined that this data collection activity is required, a detailed work plan will be developed and submitted to the stakeholders for review and comment. This work plan will address existing data, as well as the installation and sampling of new monitor wells.

\subsubsection{Aquifer testing}

Pending a review of existing data in the Grand Junction RAP (DOE, 1991), additional data may be needed on the variability of the hydraulic conductivity of the surficial aquifers downgradient of the site. This activity may require the installation of additional wells as either pumping and/or observation wells. Perhaps more importantly, the vertical hydraulic relationship between the alluvial aquifer and the Mancos Shale/Dakota Sandstone may require clarification/confirmation in the vicinity of the site. If needed, additional wells should be installed in well clusters (using all existing wells to their fullest potential) to evaluate and confirm that vertical hydraulic potentials are consistently upward between these units.

Also, aquifer testing will be used to evaluate the impact of canal leakage within the immediate vicinity of the site, specifically with regards to the impacts on ground water gradients and velocities.

If it is determined that additional hydraulic data should be collected through the use of various aquifer tests, a detailed work plan will be developed and submitted to the stakeholders for review and concurrence. 


\subsubsection{Topographic surveving}

A topographic profile across the Colorado River is required to establish references for elevations, water levels, and ground water flow.

It is presumed that the Colorado River is the local base level for the ground water regime in the alluvium downgradient of the site, and that contaminated ground water from beneath the site will not cross under the river. Additional information on the water elevation in the Colorado River is needed to confirm this supposition and to aid in model development. Surveys of the elevations of all newly installed monitoring stations (e.g., monitor wells and/or surface water locations) and the topographic profile and survey of the Colorado River will all be conducted by professional surveyors licensed in the state of Colorado. The surveys will be done in accordance with second-order topographic surveying accuracy criteria.

\subsubsection{Monitoring ground water quality}

Semiannual ground water quality data are needed from existing wells to evaluate water quality trends through time. Background water quality data in the alluvial aquifer upgradient of the site are needed to confirm naturally occurring elevated inorganic and radionuclide concentrations migrating onto the processing site. In addition, all other existing alluvial monitor wells will continue to be sampled to monitor changes in ground water quality.

\subsubsection{Ground water and surface water level elevation monitoring}

Continued monitoring of the ground water level elevations in the monitor well clusters should continue to further evaluate and assess the vertical gradients between aquifers. Consistent with this activity, all existing ground water and surface monitoring stations will be monitored for water levels on a single day on a quarterly basis to continue to evaluate the lateral and vertical hydrologic flow regimes.

\subsubsection{Geochemical analysis of ground water and aquifer matrix}

Geochemical analysis of the aquifer matrix is required to determine the interaction between the constituents in ground water and the material comprising the aquifer. These data are needed to assess contaminant migration and attenuation. These data will be used to further refine and support future solute transport modeling efforts.

Data regarding the geochemistry of both the ground water and aquifer matrix are required to determine the sorption potential of the aquifer. No such data currently exist in the Grand Junction site database, with the exception of limited $\mathrm{pH}$ and dissolved oxygen data from ground water samples. Additional information is probably required to quantify the interaction of solute during transport through the aquifer such as distribution and retardation coefficients, if 
applicable, and contaminant-specific velocities. The physical nature of the aquifer matrix will affect the dispersion and rate of migration of the plume.

If it is determined that core collection and analysis (organic compounds, inorganic compounds [mineralogy], sorption potential, isotope studies, and bulk density) should be used to collect additional geochemical data, a detailed work plan will be developed and submitted to the stakeholders for review and concurrence.

\subsubsection{Toxicological literature review}

An in-depth literature review to obtain toxicological data for contaminants of potential concern that have no state or federal water quality or sediment quality guidelines is needed to more adequately define specific contaminant impacts, if any, on public health and/or the environment.

\subsubsection{Computer modeling of ground water flow}

A quantitative evaluation of the ground water flow regime and the fate and transport of contaminants (computer modeling) is needed to complement previous evaluations and to determine and monitor the effectiveness of a natural flushing compliance strategy.

The models will integrate all the information available from the Grand Junction site and will allow quantitative evaluation of the feasibility of achieving compliance through natural flushing within 100 years.

If it is determined that models are required to support a natural flushing compliance strategy, this phase of the investigation will develop a hydrologic model that simulates the ground water flow regime at the site and predicts the transport and decay of contaminants from the site. Before initiating a full numerical computer modeling effort, a simpler analytical model will be used. This analytical model should give a reasonable estimate of the potential success of the strategy and identify major data gaps.

The analytical model will estimate the contaminant transport based on the ground water flow rate, which is calculated from an average hydraulic conductivity; the controlling gradient and cross-sectional area; and representative porosity, combined with estimated retardation factors, dispersivity, and sorption rates for the surficial aquifer.

A two-layered, three-dimensional hydrologic flow model, simulating the existing ground water flow pattern, will be developed (probably using the software package MODFLOW, according to an American Society of Testing and Materials standard currently under development). This model will incorporate the existing data on the hydrogeology and boundary conditions. It will be calibrated to emulate the existing "steady-state" conditions. The computer model will identify data gaps and uncertainties. 
A contaminant transport and decay model (probably MT3D) will then be incorporated into the flow model and calibrated with the 1987 through 1995 water quality information. The transport model will be used to generate representative retardation and decay criteria needed to make the plume migration simulation correspond to the actual changes in contaminant distributions. These generated values will be compared to the retardation and decay factors suggested by analysis of the aquifer matrix samples. If the values appear appropriate, they will be used in the predictive model. If not, this data gap will be identified. The ground water flow and contaminant transport and decay models will be used to predict the feasibility of the natural flushing compliance strategy. The model will also be used to identify appropriate future sampling needs and schedules to ensure the compliance strategy is working as predicted.

\subsubsection{Feasibility of implementing institutional controls}

The DOE needs to work with state and local authorities to identify the roles and responsibilities for implementing institutional controls at the site. In addition, it needs to be determined if existing institutional controls will be adequate to protect human health and the environment. 


\subsection{LIST OF CONTRIBUTORS}

The following individuals contributed to the preparation of this SOWP.

\begin{tabular}{ll}
\hline Name & Contribution \\
\hline W. Migdal & Document sponsor, document review \\
A. Vollmer & $\begin{array}{l}\text { Document coordination, regulatory } \\
\text { compliance }\end{array}$ \\
C. Yancey & Lead author \\
T. Monks, L. Pivonka & Hydrogeology \\
J. Marshall & Risk assessment \\
C. Burt & Ecology \\
D. Erskine & Geochemistry \\
A. Holm, B. Malczewska-Toth, J. Gibb, & Document review \\
R. Neri Zagal, J. Ritchey, R. Saar & \\
J. Jones, J. Torline & Technical editing, document production \\
J. Martin, L. Sanchez, WordCenter, Inc. & Word processing \\
T. Bond, B. Harvey & Graphic design \\
\hline
\end{tabular}




\subsection{REFERENCES}

Allison et al. (J. D. Allison, D. S. Brown, and K. J. Novo-Gradac), 1991. MINTEQA2/PRODEFA2, A Geochemical Assessment Model for Environmental Systems: Version 3.0 User's Manual, EPA/600/3-91/021, U.S. Environmental Protection Agency, Environmental Research Laboratory, Office of Research and Development, Athens, Georgia.

Brookins, D. G., 1988. Eh-pH Diagrams for Geochemistry, Springer-Verlag, New York, New York.

Butler et al. (D. L. Butler, W. G. Wright, D. A. Hahn, R. P. Krueger, and B. C. Osmundson), 1994. Physical, Chemical, and Biological Data for Detailed Study of Irrigation Drainage in the Uncompahgre Project Area and in the Grand Valley, WestCentral Colorado, 1991-1992, U.S. Geological Survey Open File Report 94-110.

Cahn et al. (L. S. Cahn, M. R. Meininger, and J. E. Price), 1988. Potential Groundwater Contamination at Grand Junction UMTRAP Vicinity Properties, DOE/ID/1258433, prepared by UNC Geotech for the U.S. Department of Energy, Grand Junction Projects Office, Grand Junction, Colorado.

Cooley et al. (M. E. Cooley, S. W. Harshberger, J. P. Akers, and W. P. Hardt), 1969. Regional Hydrogeology of the Navajo and Hopi Indian Reservations, Arizona, New Mexico, and Utah, U.S. Geological Survey Professional Paper 521-A.

DOE (U.S. Department of Energy), 1995a. Draft Programmatic Environmental Impact Statement for the Uranium Mill Tailings Remedial Action Ground Water Project, DOE/EIS-0198, U.S. Department of Energy, UMTRA Project Office, Albuquerque Operations Office, Albuquerque, New Mexico.

DOE (U.S. Department of Energy), 1995b. Baseline Risk Assessment of Ground Water Contamination at the Uranium Mill Tailings Site at Grand Junction, Colorado, DOE/AL/62350-104, Rev. 2, prepared for the U.S. Department of Energy, Environmental Restoration Division, UMTRA Project Team, Albuquerque, New Mexico.

DOE (U.S. Department of Energy), 1995c. UMTRA Project Water Sampling and Analysis Plan, Grand Junction, Colorado, DOE/AL/62350-133, Rev. 1, prepared for the U.S. Department of Energy, Environmental Restoration Division, UMTRA Project Team, Albuquerque, New Mexico.

DOE (U.S. Department of Energy), 1994a. Human Health Risk Assessment Methodology for the UMTRA Ground Water Project, DOE/AL/62350-170, prepared for the U.S. Department of Energy, UMTRA Project Office, Albuquerque Operations Office, Albuquerque, New Mexico. 
DOE (U.S. Department of Energy), 1994b. "Attachment 4, Water Resources Protection Strategy," Remedial Action Plan and Site Design for Stabilization of the Inactive Uranium Mill Tailings Site, Maybell, Colorado, DOE/AL/62350-24F, prepared for the U.S. Department of Energy, UMTRA Project Office, Albuquerque Operations Office, Albuquerque, New Mexico.

DOE (U.S. Department of Energy), 1993a. UMTRA Ground Water Project Plan, UMTRADOE/AL-62350-1, prepared for the U.S. Department of Energy, UMTRA Project Office, Albuquerque Operations Office, Albuquerque, New Mexico.

DOE (U.S. Department of Energy), 1993b. Technical Approach to Groundwater Restoration, DOE/AL/62350-20F, prepared for the U.S. Department of Energy, UMTRA Project Office, Albuquerque Operations Office, Albuquerque, New Mexico.

DOE (U.S. Department of Energy), 1991. Remedial Action Plan and Site Design for Stabilization of the Inactive Uranium Mill Tailings Site at Grand Junction, Colorado, UMTRA-DOE/AL-050505.0000, prepared for the U.S. Department of Energy, UMTRA Project Office, Albuquerque Operations Office, Albuquerque, New Mexico.

DOE (U.S. Department of Energy), 1986. Environmental Impact Statement - Remedial Actions at the Former Climax Uranium Company Uranium Mill Site, Grand Junction, Mesa County, Colorado, DOE/EIS-126-F, prepared for the U.S. Department of Energy, UMTRA Project Office, Albuquerque Operations Office, Albuquerque, New Mexico.

DOE (U.S. Department of Energy), 1981. Cooperative Agreement between the United States Department of Energy and the State of Colorado, DE-FC04-81 AL16257. prepared for the U.S. Department of Energy, UMTRA Project Office, Albuquerque Operations Office, Albuquerque, New Mexico.

EPA (U.S. Environmental Protection Agency), 1989. Risk Assessment Guidance for Superfund, Vol. II, Environmental Evaluation Manual, EPA/540/1-89/001, U.S. Environmental Protection Agency, Office of Emergency and Remedial Response, Washington, D.C.

EPA (U.S. Environmental Protection Agency), 1973. Water Quality Criteria, National Academy of Science and National Academy of Engineering, Washington, D.C.

Evangelou et al. (V. P. Evangelou, L. D. Whittig, and K. K. Tanji), 1984. "Dissolved Mineral Salts Derived from Mancos Shale," J. Environ. Qual., Vol. 13, No. 1.

FBDU (Ford, Bacon \& Davis Utah, Inc.), 1981. Engineering Assessment of Inactive Uranium Mill Tailings, Grand Junction Site, Grand Junction, Colorado, prepared by Ford, Bacon \& Davis Utah, Inc., for the U.S. Department of Energy, UMTRA Project Office, Albuquerque Operations Office, Albuquerque, New Mexico. 
Ferris, J. G., and D. B. Knowles, 1963. "The Slug-Injection Test for Estimating the Coefficient of Transmissibility of an Aquifer," in Methods of Determining Permeability, Transmissibility, and Drawdown, R. Bentall, editor, U.S. Geological Survey Water-Supply Paper 1536-1, U.S. Government Printing Office, Washington, D.C.

Hem, J. D., 1992. Study and Interpretation of the Chemical Characteristics of Natural Water, Third Edition, U.S. Geological Survey Water-Supply Paper 2254, U.S. Government Printing Office, Washington, D.C.

Heyman, O. G., 1983. "Distribution of Structural Geometry of Faults and Folds Along the Northwestern Uncompahgre Uplift, Western Colorado and Eastern Utah," in Northern Paradox Basin - Uncompahgre Uplift, Field Trip, 1-2 October, W. R. Averett, ed., Grand Junction Geological Society, Grand Junction, Colorado.

Hill, S. R., 1989. Jacobs Engineering Group Inc., personal communication to M. Matthews, DOE UMTRA Project Office, Appendix IX Screening, UPDCC File Location No. 0.2.2.38.41, Albuquerque, New Mexico, 8 November 1989.

Lohman, S. W., 1972. Ground Water Hydraulics, U.S. Geological Survey Professional Paper 708, U.S. Government Printing Office, Washington, D.C.

Lohman, S. W., 1965. Geology and Artesian Water Supply, Grand Junction Area, Colorado, U.S. Geological Survey Professional Paper 451, U.S. Government Printing Office, Washington, D.C.

Merritt, R. C., 1971. The Extractive Metallurgy of Uranium, Colorado School of Mines Research Institute, Golden, Colorado.

Opresko et al. (D. M. Opresko, B. E. Sample, and G. W. Suter), 1994. Toxicological Benchmarks for Wildlife: 1994 Revision, ES/ER/TM-86/RI, prepared for the U.S. Department of Energy, Oak Ridge National Laboratory, Oak Ridge, Tennessee.

Parkhurst et al. (D. L. Parkhurst, D. C. Thorstenson, and L. N. Plummer), 1980. PHREEQE - A Computer Program for Geochemical Calculations, U.S. Geological Survey Water Resources Investigation 80-96, National Technical Information Services Report PB81-167-801, Springfield, Virginia.

Pliler, R., and J. A. S. Adams, 1962. "The Distribution of Thorium, Uranium, and Potassium in the Mancos Shale," Geochimica et Cosmochimica Acta, Vol. 26, pp. 1115-1135.

Skibitzke, 1963. "Determination of the Coefficient of Transmissibility from Measurements of Residual Drawdown in the Bailed Well," Methods of Determining Permeability, Transmissibility, and Drawdown, R. Bentall, ed., U.S. Geological Survey WaterSupply Paper 1536-1, U.S. Government Printing Office, Washington, D.C. 
Suter, G. W., and J. B. Mabrey, 1994. Toxicological Benchmarks for Screening Potential Contaminants of Concern for Effects on Aquatic Biota: 1994 Revision, ES/ER/TM-96/RI, prepared for the U.S. Department of Energy, Oak Ridge National Laboratory, Oak Ridge, Tennessee.

USBR (U.S. Bureau of Reclamation), 1986. "Cobble Aquifer Investigation," Colorado River Basin Salinity Control Project, Grand Valley Unit - Stage II, U.S. Bureau of Reclamation, Grand Junction Projects Office, Geology Branch, Grand Junction, Colorado.

USBR (U.S. Bureau of Reclamation), 1978. "Appendix B to Stage One Development, Grand Valley Unit, Definite Plan Report," Colorado River Basin Salinity Control Project, U.S. Bureau of Reclamation, Upper Colorado Region, Grand Junction, Colorado.

USBR (U.S. Bureau of Reclamation), n.d. Miscellaneous unpublished data, Colorado River Water Quality Improvement Program, UPDCC File Location No. 5.19.2.5, Albuquerque, New Mexico.

USGS (U.S. Geological Survey), 1995. "Water Year-1995, Surface Water Discharge Records: Colorado River Near Cameo, Colorado River at State Line," U.S. Geological Survey, Grand Junction, Colorado.

Will, M. E., and G. W. Suter, 1994. Toxicological Benchmarks for Screening Potential Contaminants of Concern for Effects on Terrestrial Plants: 1994 Revision, ES/ER/TM-85/RI, prepared for the U.S. Department of Energy, Oak Ridge National Laboratory, Oak Ridge, Tennessee.

\section{CODE OF FEDERAL REGULATIONS}

10 CFR Part 1021, Compliance with National Environmental Policy Act, U.S. Department of Energy.

40 CFR Part 141, National Primary Drinking Water Regulations, U.S. Environmental Protection Agency.

40 CFR Part 143, National Secondary Drinking Water Regulations, U.S. Environmental Protection Agency.

40 CFR Part 192, Health and Environmental Protection Standards for Uranium and Thorium Mill Tailings, U.S. Environmental Protection Agency.

40 CFR Part 264, Standards for Owners and Operators of Hazardous Waste Treatment, Storage, and Disposal Facilities, U.S. Environmental Protection Agency.

40 CFR Part 300, National Oil and Hazardous Substances Pollution Contingency Plan, U.S. Environmental Protection Agency. 
40 CFR Parts 1500-1508, Regulations for Implementing the Procedural Provisions of the National Environmental Policy Act, Council on Environmental Quality.

\section{FEDERAL REGISTER}

56 FR 33050, "National Primary Drinking Water Regulations; Radionuclides," Notice of Proposed Rulemaking, 18 July 1991, U.S. Environmental Protection Agency.

60 FR 2854, "Groundwater Standards for Remedial Actions at Inactive Uranium Processing Sites," final rule, 11 January 1995, U.S. Environmental Protection Agency.

\section{U.S. CODE}

42 USC $\$ 4321$ et seq., National Environmental Policy Act.

42 USC $\$ 7901$ et seq., Uranium Mill Tailings Radiation Control Act, as amended.

\section{DOE ORDERS}

Order 451.1, National Environmental Policy Act Compliance Program, 11 September 1995. 
APPENDIX A

LITHOLOGIC LOGS

WELL COMPLETION RECORDS

WELL CONSTRUCTION DATA 
PROJECT GRAND JUNCTION PROCESS SITE

LOG OF WELL BORING NO.

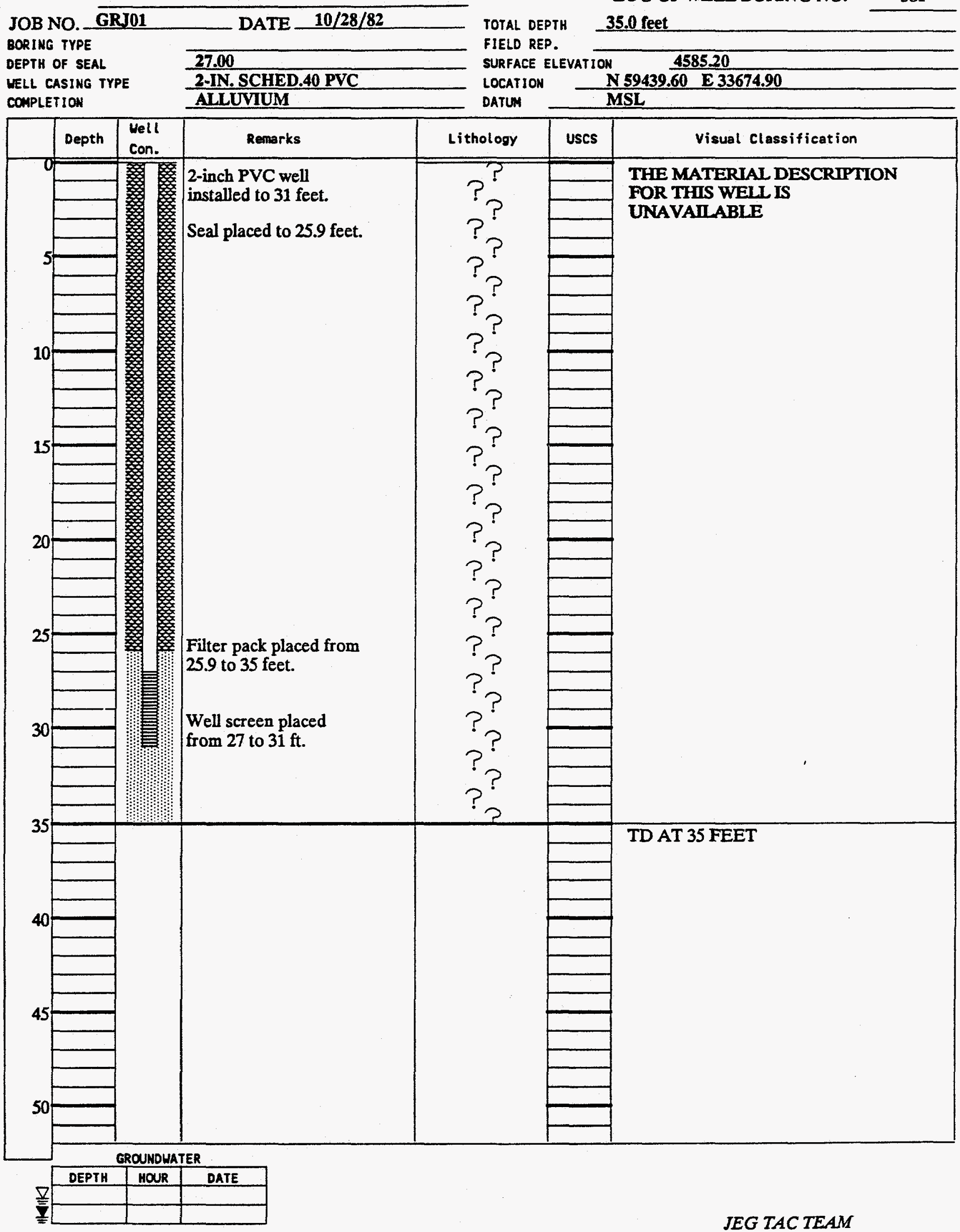


PROJECT GRAND JUNCTION PROCESS SITE

JOB NO. GRJ01

BORING TYPE

DEPTH OF SEAL

WELL CASING TYPE

COMPLETION

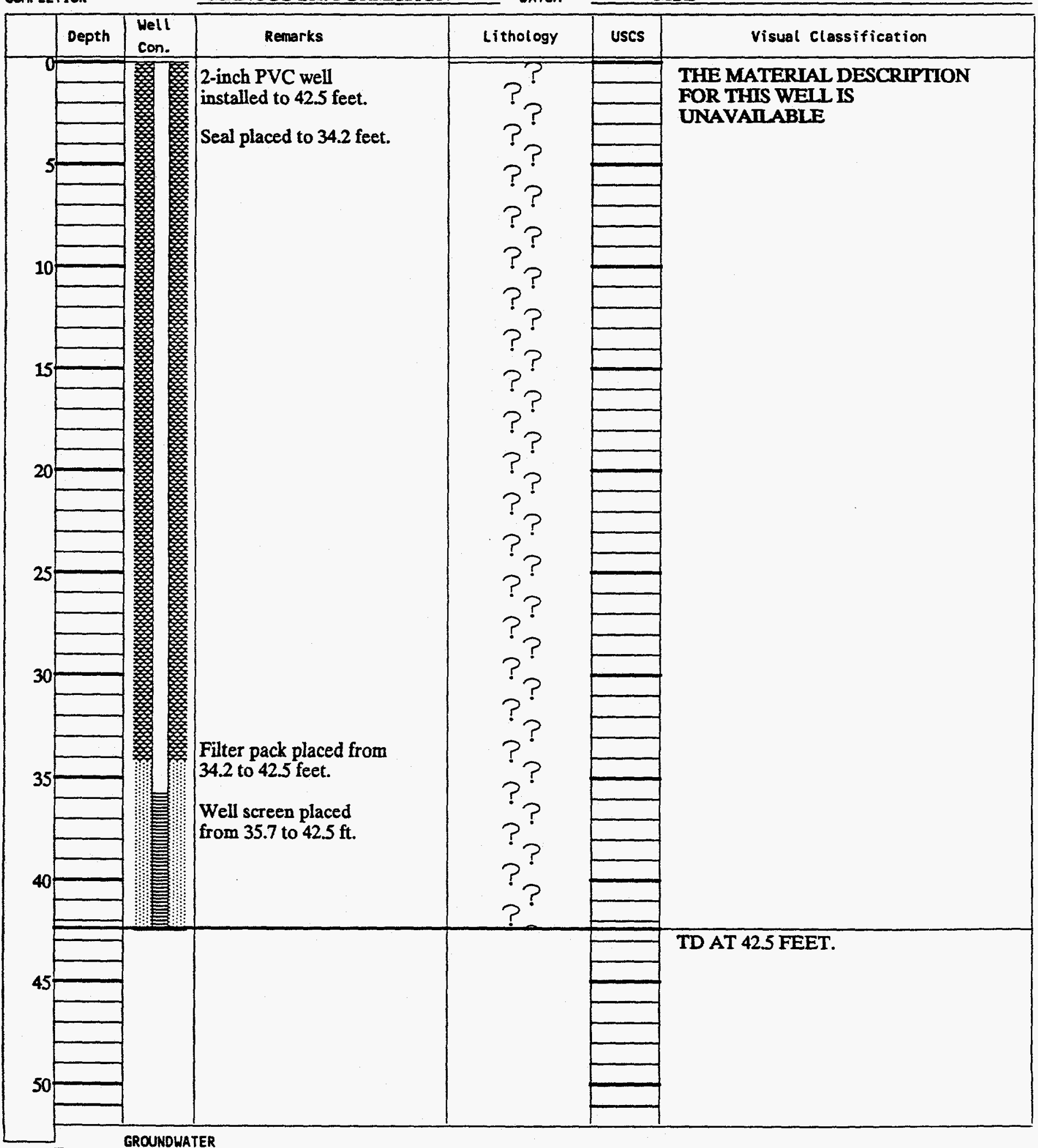

DATE $10 / 30 / 82$

$\mathbf{3 5 . 7 0}$

2-IN. SCHED.40 PVC
LOG OF WELL BORING NO.

TOTAL DEPTH 42.5 feet

FIELD REP.

SURFACE ELEVATION 458530

LOCATION

N $59310.00 \quad$ E 33151.80

MSL

THE MATERIAL DESCRIPTION

FOR THIS WELL IS

2-inch PVC $25 \mathrm{feet}$

Seal placed to 34.2 feet.

Filter pack placed from

Well screen placed

from 35.7 to $42.5 \mathrm{ft}$.

Page 1 ret

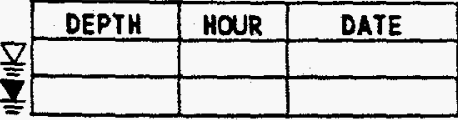


PROJECT GRAND JUNCTIUN PKUCESS SIIE

JOB NO. GRJ01

BORING TYPE

DEPTH OF SEAL

MELL CASING TYPE

COMPLETION

CONPLETION
DATE $10 / 31 / 82$

28.70

2-IN. SCHED.40 PVC

ALLUVIUM

TOTAL DEPTH
FIELD REP.
SURFACE ELEVATION
LOCATION $\frac{4585.10}{\mathrm{~N} 59316.80 \quad \mathbf{3 3 1 4 1 . 5 0}}$
DATUM

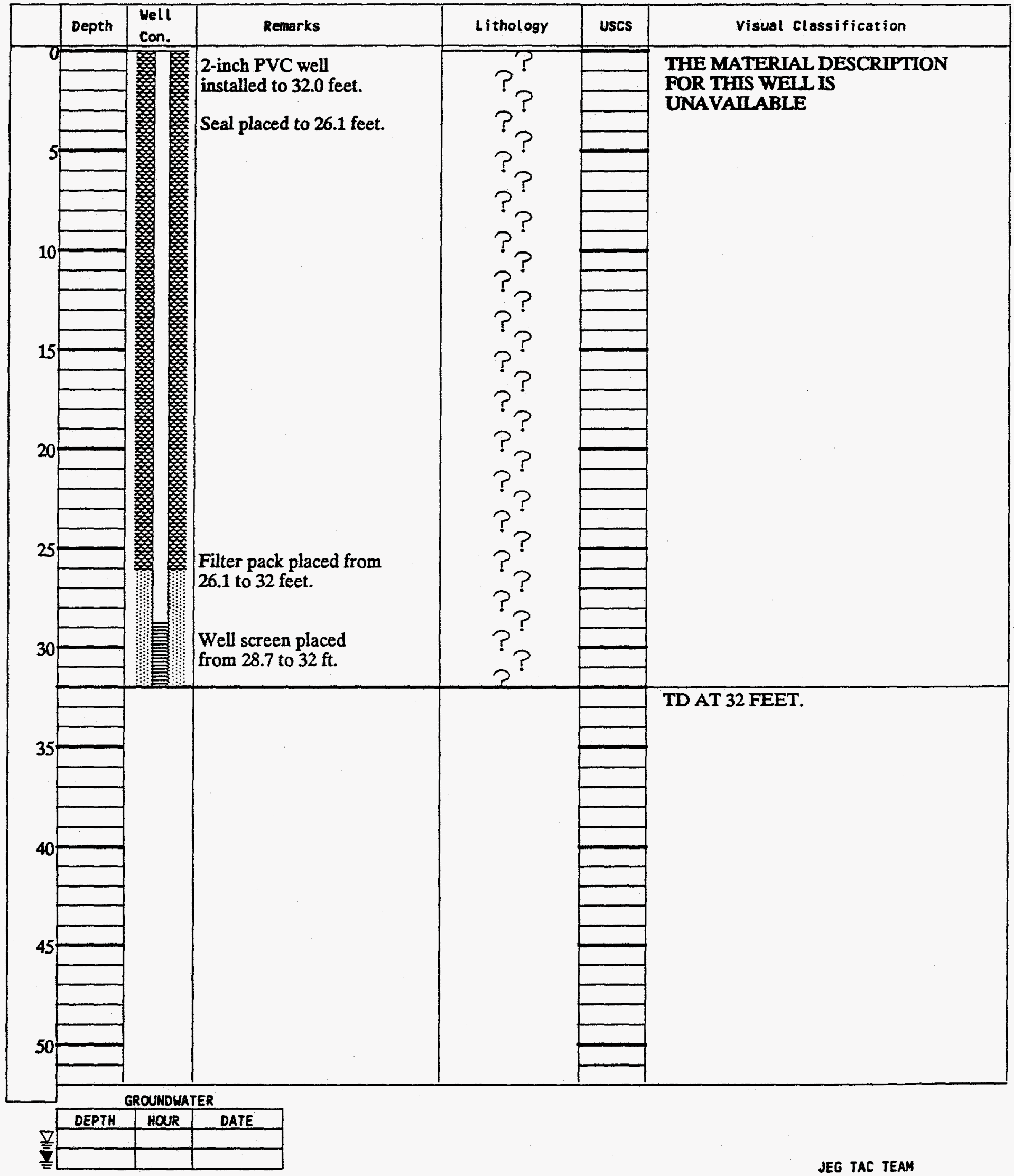


PROJECT GRAND JUNCTION PROCESS SITE JOB NO. GRJO
BORING TYPE

DEPTH OF SEAL

MELL CASING TYPE

COMPLETION

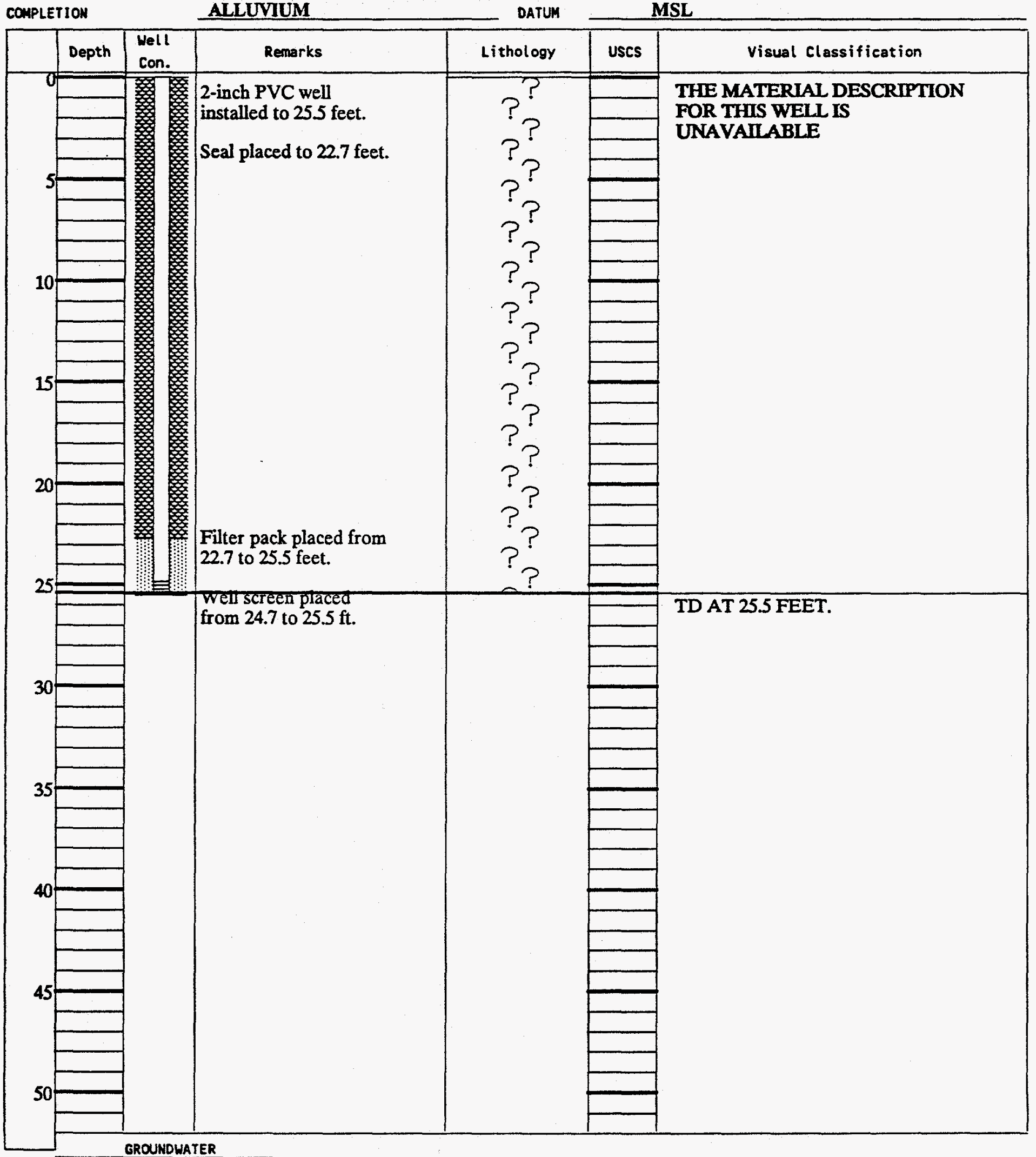

LOG OF WELL BORING NO.

TOTAL DEPTH 25.5 feet

FIELD REP.

SURFACE ELEVATION 4585.00

LOCATION N 59321.00 E 33153.80

2-IN. SCHED.40 PVC

ALLUVIUM

DATE $10 / 31 / 82$

$-$

2-inch PVC well

Seal placed to 22.7 feet.

Filter pack placed from

22.7 to 25.5 feet

well screen placed

DATE

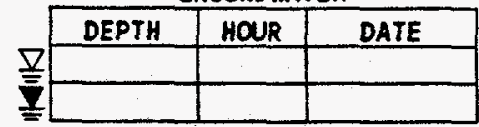


PROJECT GRAND JUNCTION PROCESS SITE

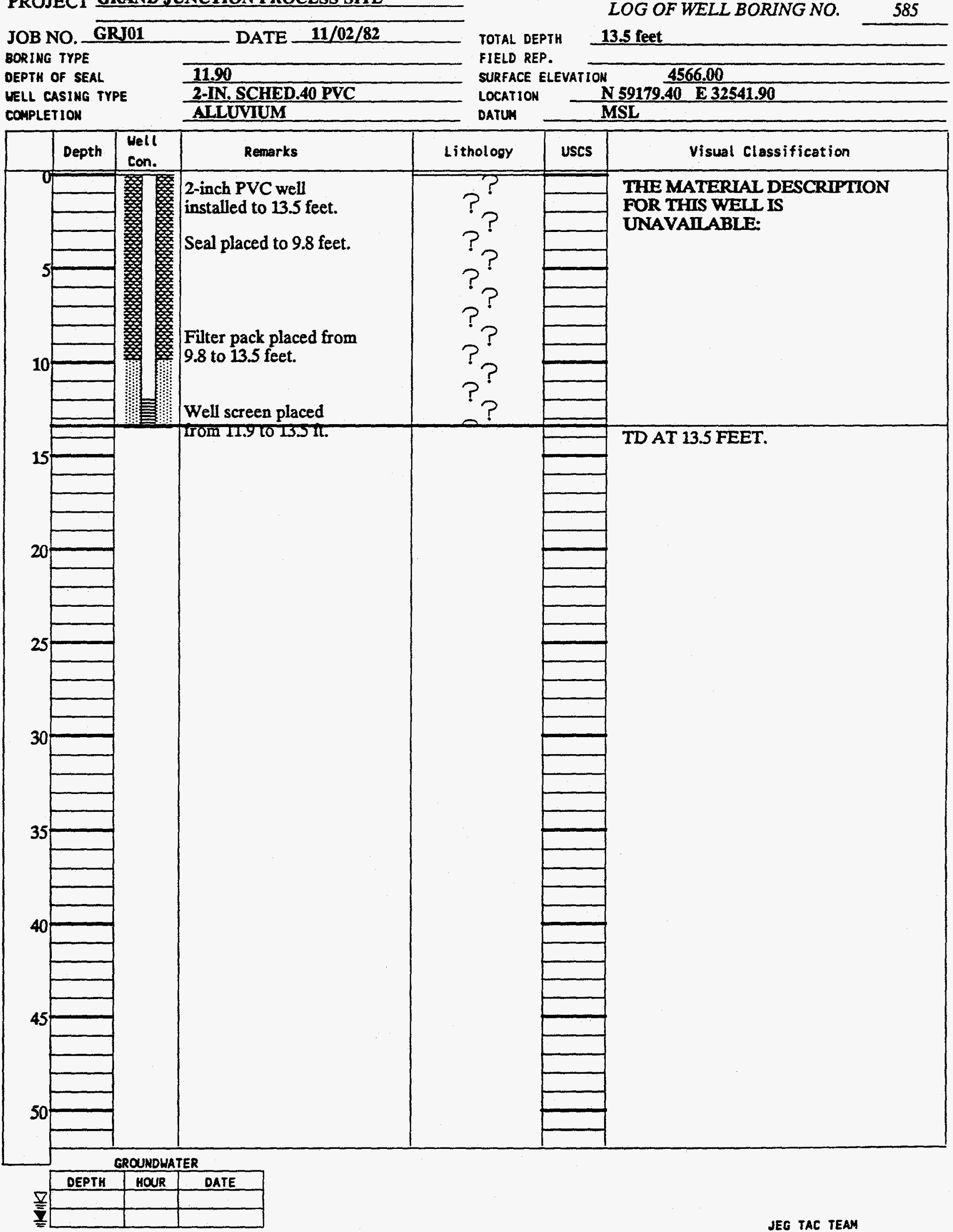


PROJECT GRAND JUNCTION PROCESS SITE

JOB NO. GRJ01

BORING TYPE

DEPTH OF SEAL

WELL CASING TYPE

COMPLETION
DATE 11/01/82

5.50

2.IN. SCHED.40 PVC

ALLUVIUM

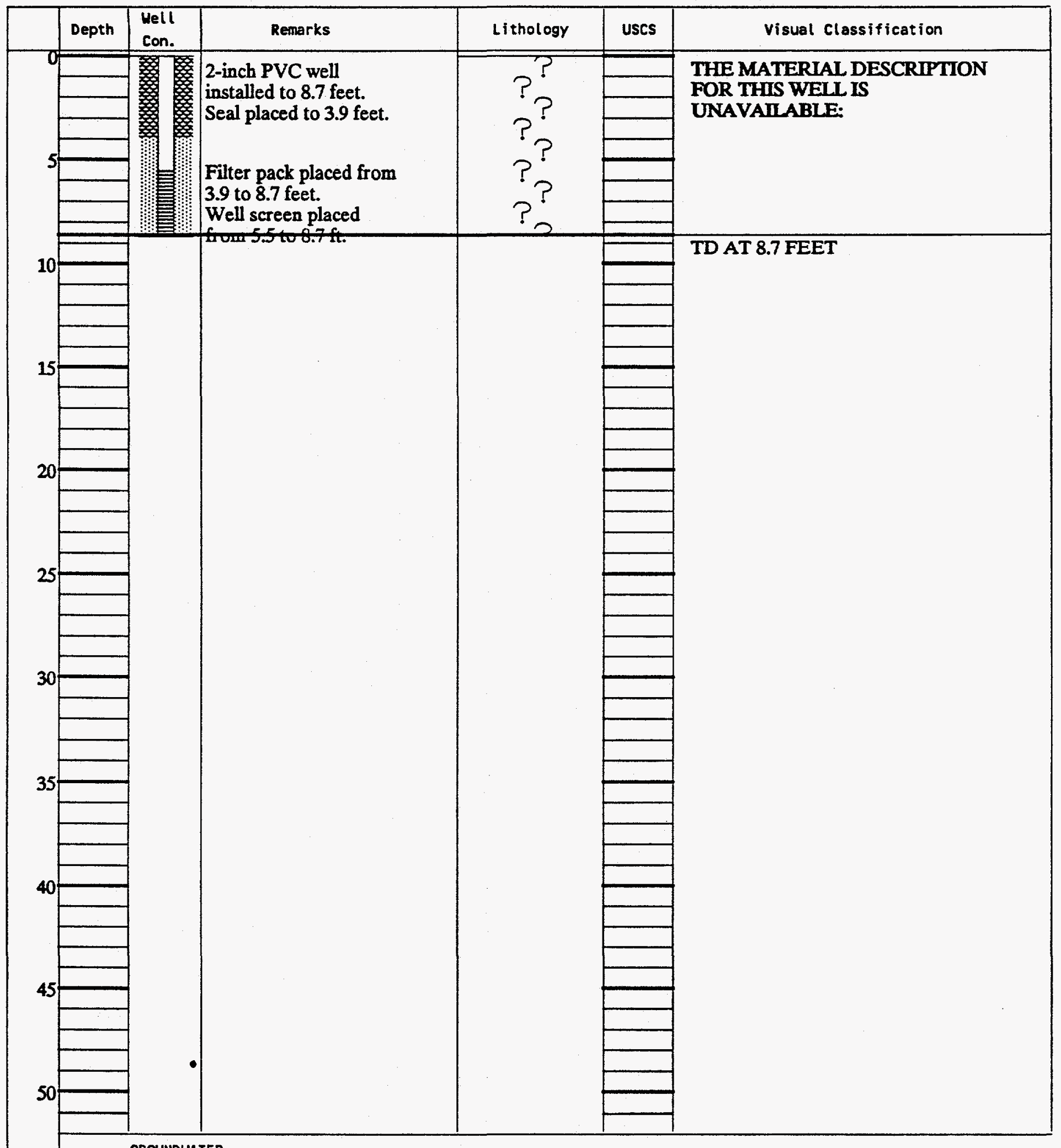

GROUNDWATER

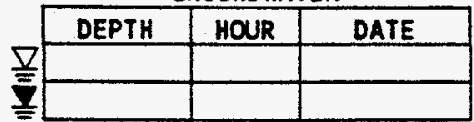


PROJECT GRAND JUNCTION PROCESS SITE

\begin{tabular}{l} 
JOB NO. GRJ01 \\
$\begin{array}{l}\text { BORING TYPE } \\
\text { DEPTH OF SEAL } \\
\text { LELL CASING TYPE } \\
\text { COMPLETION }\end{array} \quad$ DATE 12/16/82 \\
\hline
\end{tabular}

TOTAL DEPTH 15.5 feet

FIELD REP.

SURFACE ELEVATION 4575.00

COMPLETION

ALLUVIUM

LOCATION

DATUM

N $60599.90 \quad$ E 34829.20

MSL

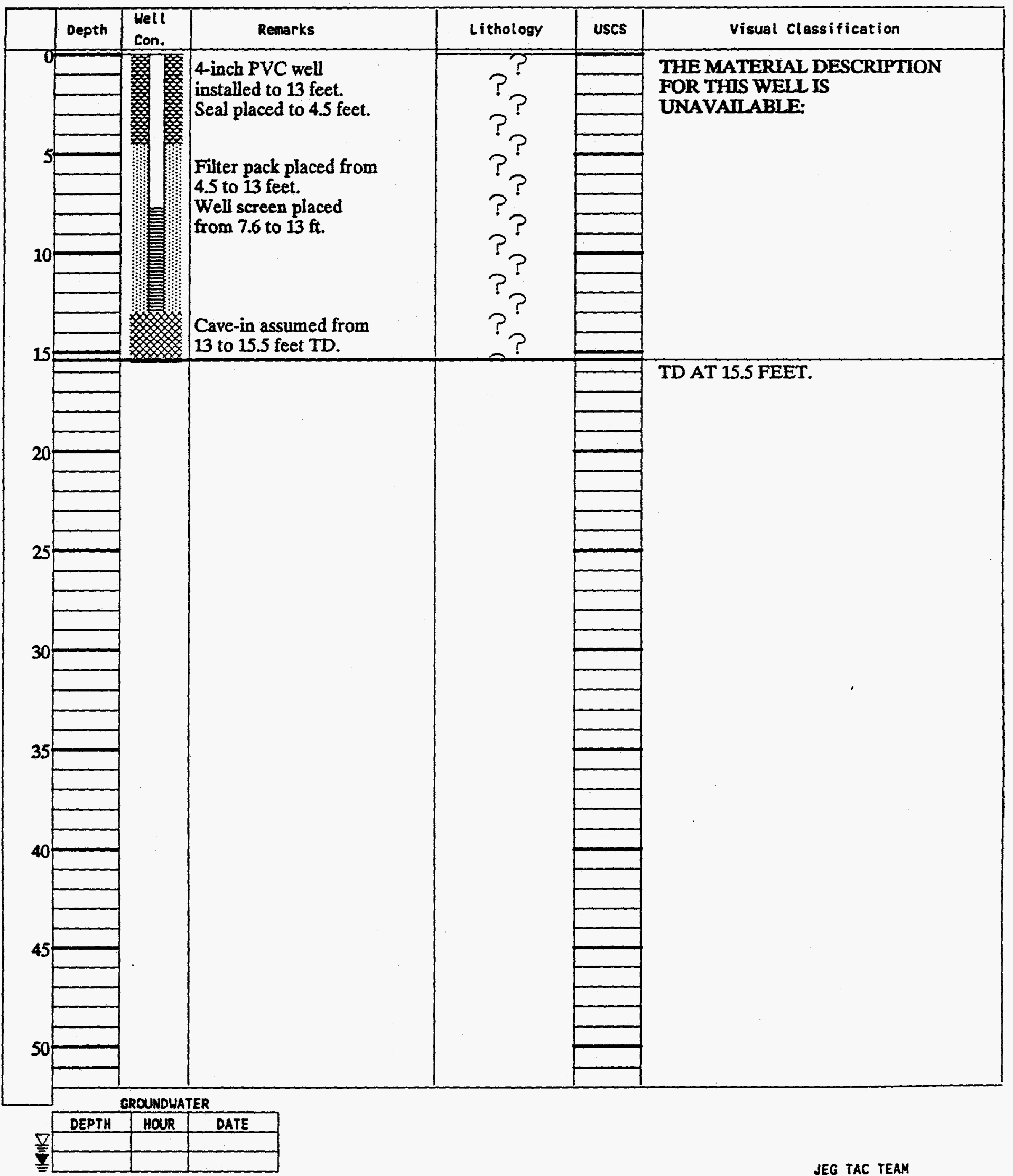


PROJECT GRAND JUNCTION PROCESS SITE

JOB NO. GRJ01

BORING TYPE

DEPTH OF SEAL

WELL CASING TYPE

COMPLETIOW

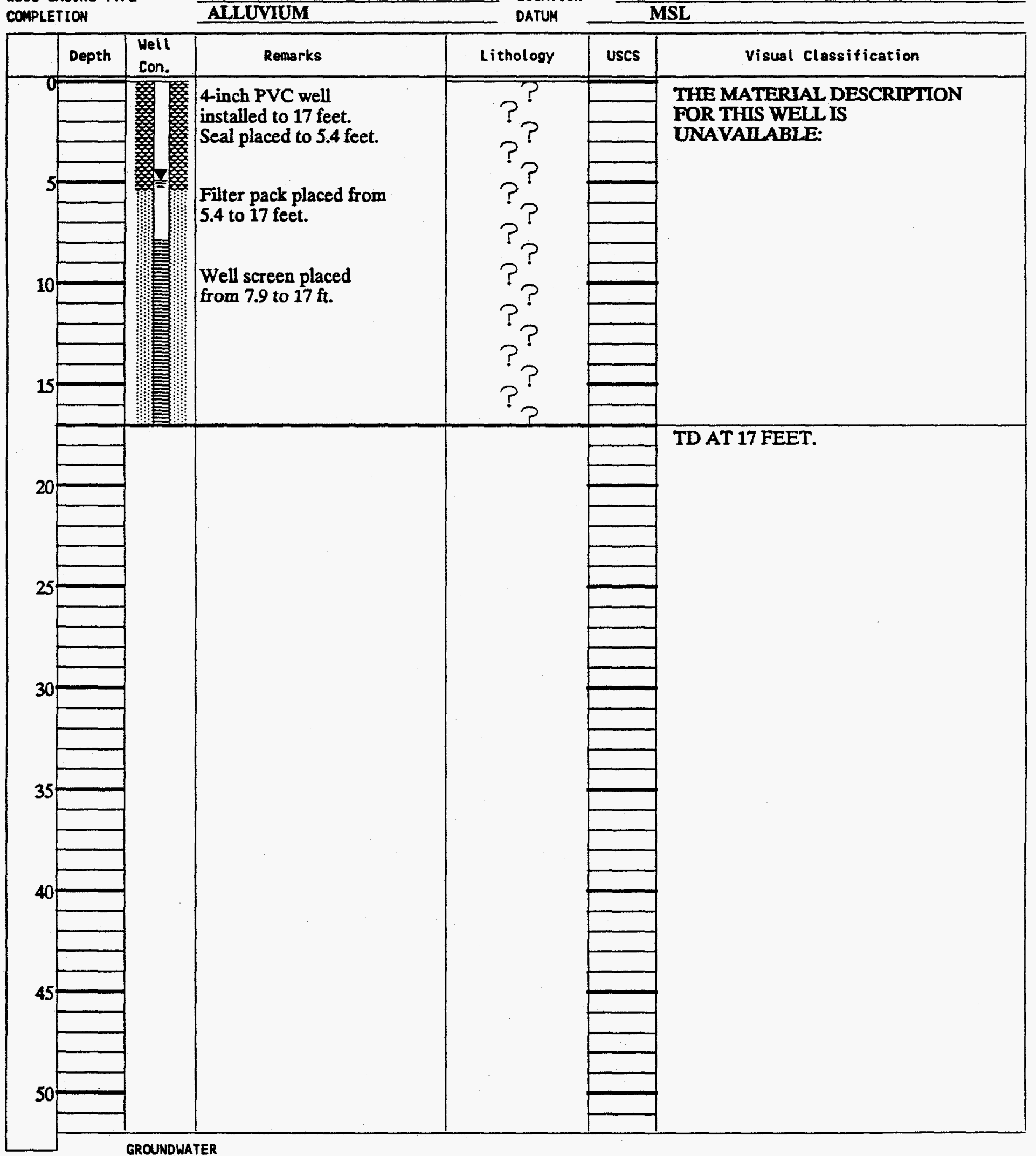

7.90

4-IN. SCHED.40 PVC ALLUVIUM

4-inch PVC well

installed to 17 feet.

Filter pack placed from

5.4 to 17 feet.

Well screen placed from 7.9 to $17 \mathrm{ft}$.
DATE 12/12/82

TOTAL DEPTH 17.0 feet

FIELD REP.

SURFACE ELEVATION 4571.50

LOCATION N 59447.60 E 35959.70

MSL

7.60 E 35959.70 


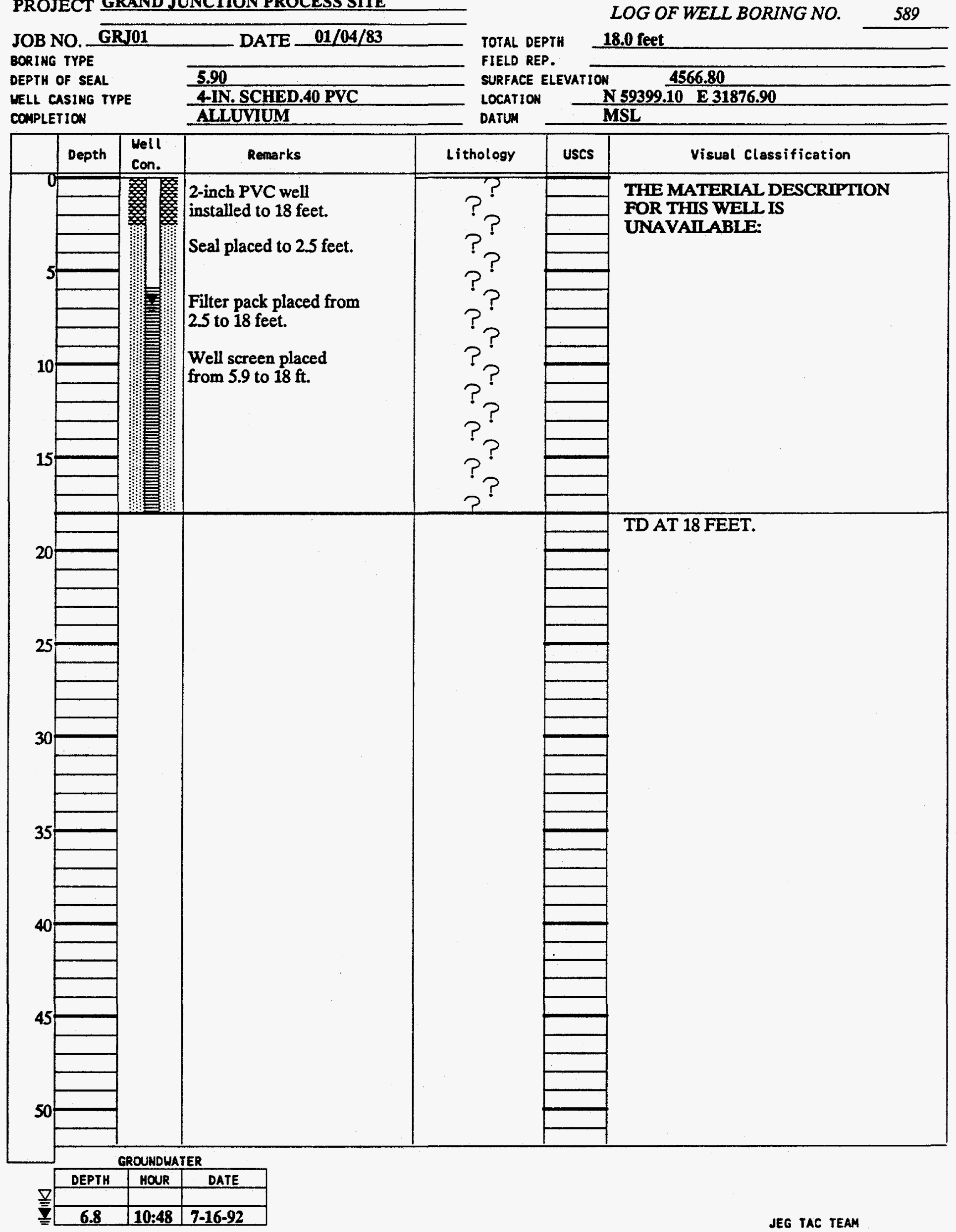


PROJECT GRAND JUNCTION PROCESS SITE

JOB NO. GRJ01 DATE 01/04/83

BORING TYPE

DEPTH OF SEAL

MELL CASING TYPE

COMPLETION

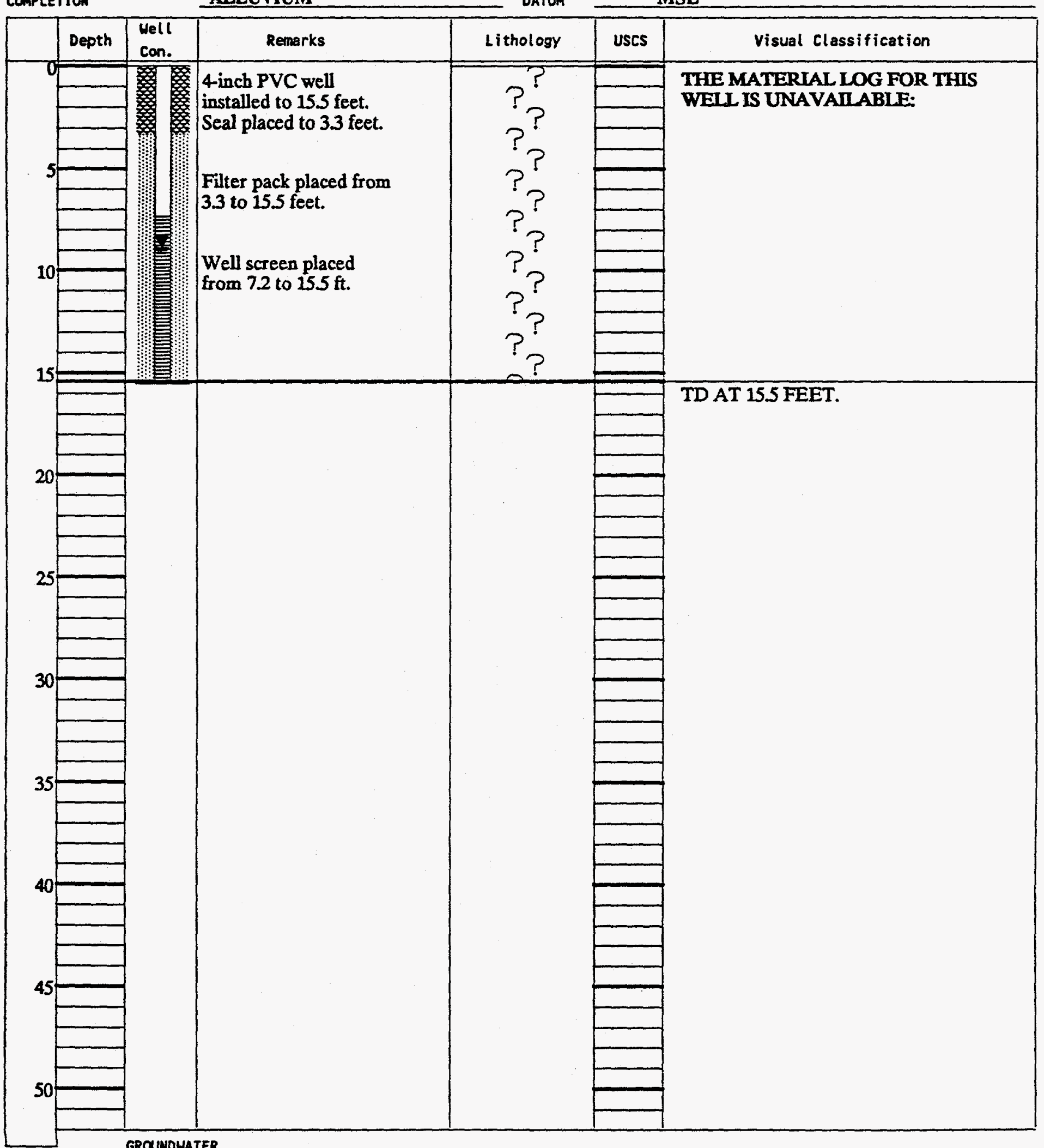

GROUMOWATER

TOTAL DEPTH 15.5 feet

FIELD REP.

SURFACE ELEVATION $\quad \mathbf{4 5 6 4 . 7 0}$

LOCATION N 59531.20 E 31295.80

4-IN. SCHED.40 PVC — LOCATIO

MSL

THE MATERIAL LOG FOR THIS

4-inch PVC well

installed to 15.5 feet.

Filter pack placed from

Well screen placed

from 7.2 to $15.5 \mathrm{ft}$

\begin{tabular}{|c|c|c|}
\hline DEPTH & HOUR & DATE \\
\hline 00 & & 70 \\
\hline
\end{tabular}




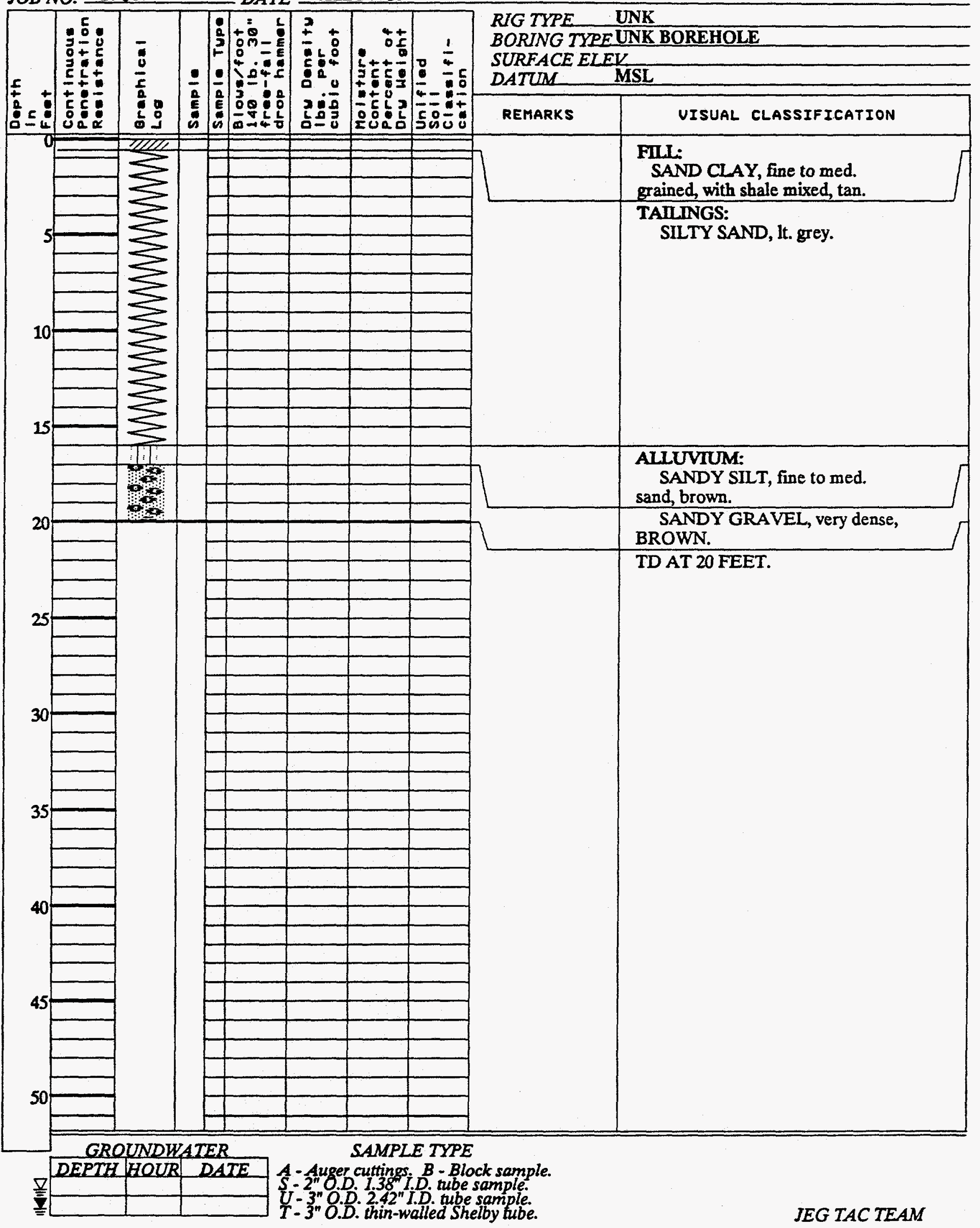




\begin{tabular}{ll} 
JOB NO. GRJ01 & \multicolumn{1}{c}{ DATE $10 / 21 / 82$} \\
BORING TYPE & \\
DEPTH OF SEAL & 29.90 \\
MELL CASING TYPE & 2-IN. SCHED.40 PVC \\
COMPLETION & ALLUVIUM
\end{tabular}

TOTAL DEPTH 33.0 feet

FIELD REP. UNK

SURFACE ELEVATION 4590.90

Location N 59215.10 E 33788.20

COMPLETION

DATUM MSL

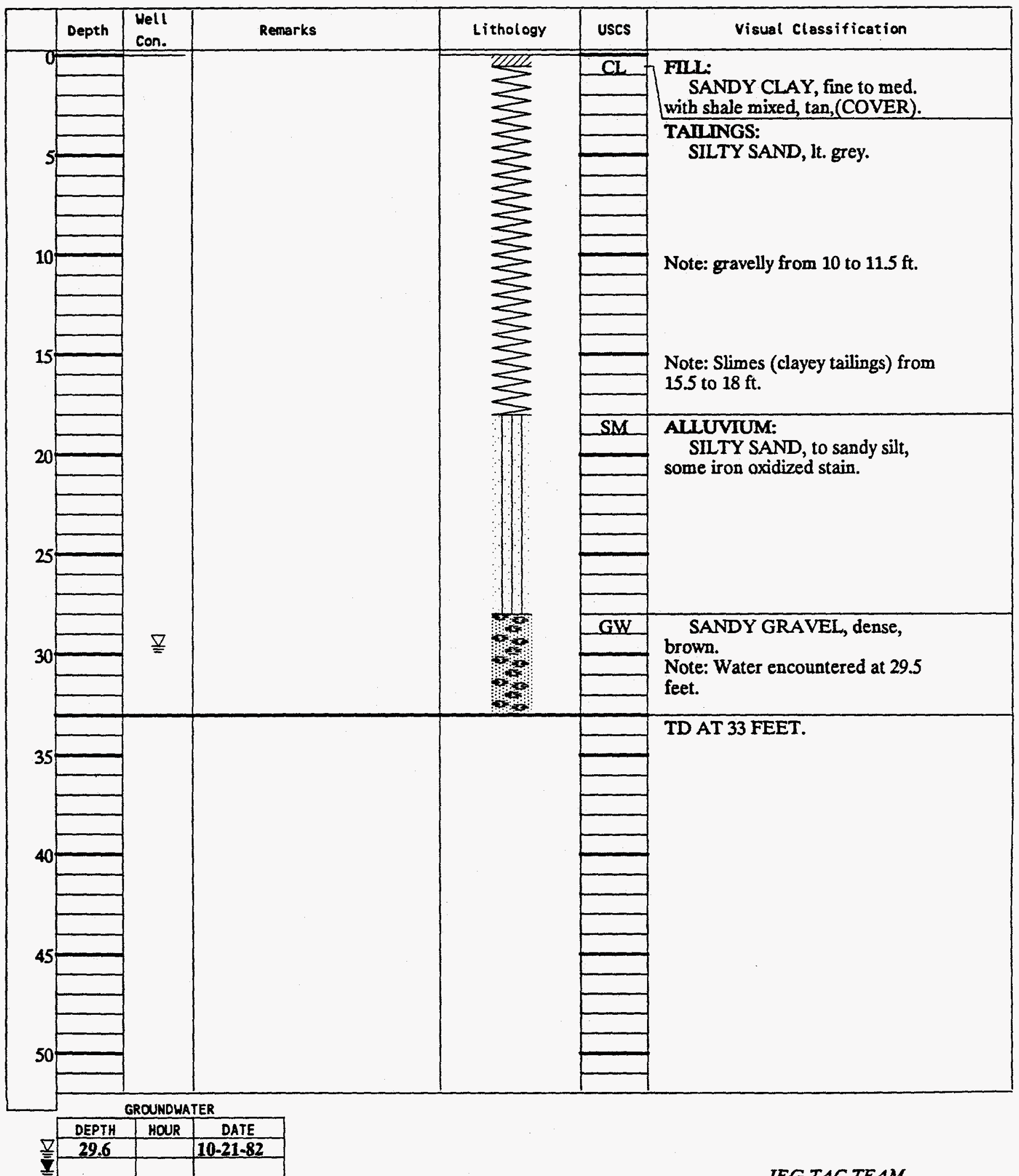




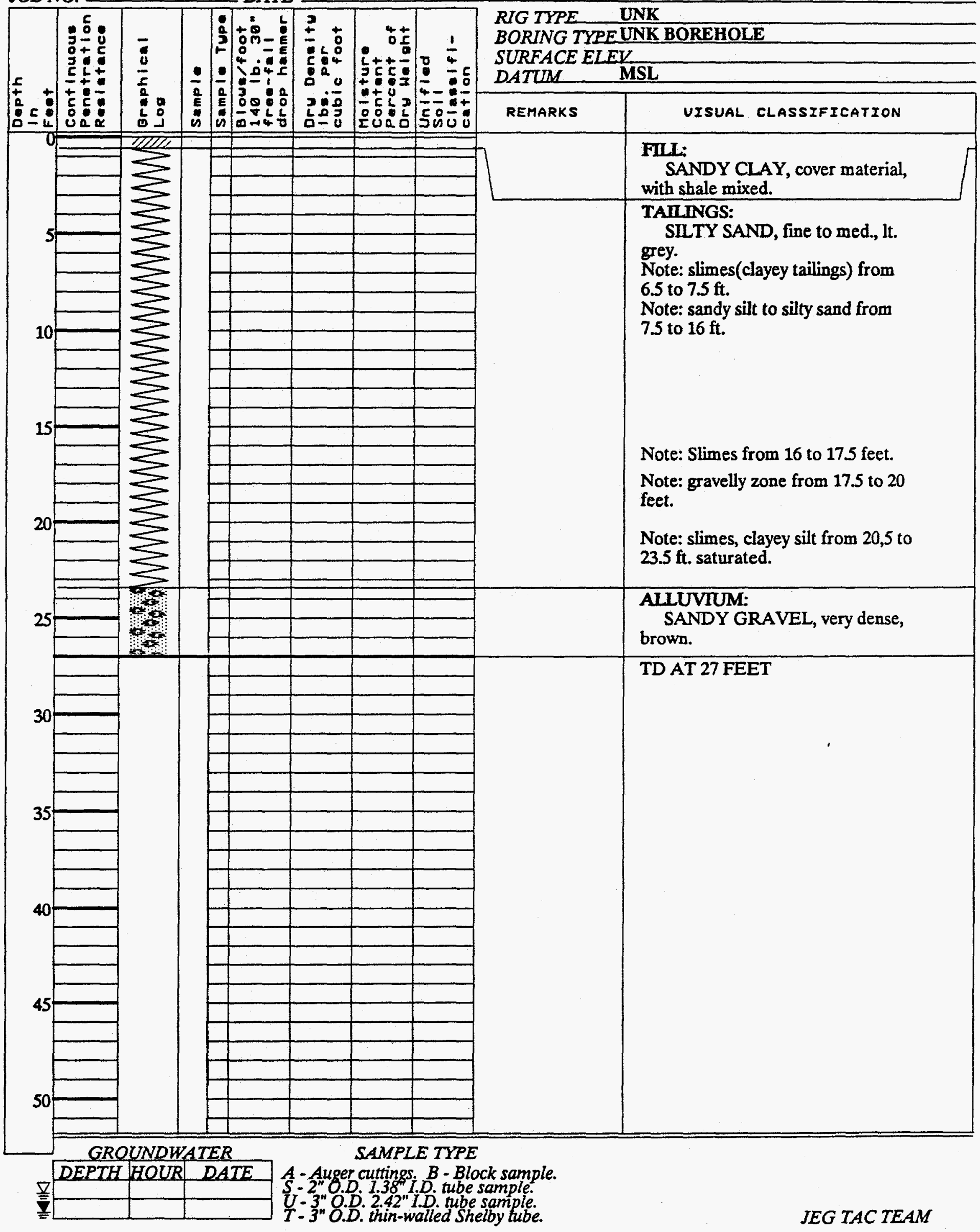


PROJECT GRAND JUNCTION PROCESS SITE

\begin{tabular}{ll} 
JOB NO. GRJ01 & \multicolumn{1}{c}{ DATE 10/22/82 } \\
BORING TYPE & UNK \\
DEPTH OF SEAL & 56.40 \\
UELL CASING TYPE & 2-IN. SCHED.40 PVC \\
COMPLETION & ALLUVIUM
\end{tabular}

TOTAL DEPTH $\frac{59.5 \text { feet }}{\text { UNK }}$
FIELO REP.
SURFACE ELEVATION
LOCATION $\frac{\mathbf{4 6 1 2 . 4 0}}{\mathrm{N} 59789.80 \text { E } 34559.60}$
DATUM

\begin{tabular}{|l|l|l|l|l|}
\hline & Depth & $\begin{array}{l}\text { Well } \\
\text { Con. }\end{array}$ & Remarks & Lith \\
\hline
\end{tabular}

\section{Litho}

\begin{tabular}{|l|l|l|l|l}
\hline & FIL: \\
SANDY CLAY, cover material, \\
with shale mixed, tan.
\end{tabular}

SILTY SAND-SANDY SILT, It. grey, intercalated lenses. 
PROJECT GRAND JUNCTION PROCESS SITE

\begin{tabular}{ll}
\hline JOB NO. GRJ01 & \multicolumn{1}{c}{ DATE $10 / 22 / 82$} \\
BORING TYPE & UNK \\
DEPTH OF SEAL & 56.40 \\
MELL CASING TYPE & 2-IN. SCHED.40 PVC \\
COMPLETION & ALLUVIUM \\
\hline
\end{tabular}

TOTAL DEPTH 59.5 feet

FIELD REP. UNK

SURFACE ELEVATION $\mathbf{4 6 1 2 . 4 0}$

LOCATION N 59789.80 E 34559.60

COMPLETION

DATUM

MSL

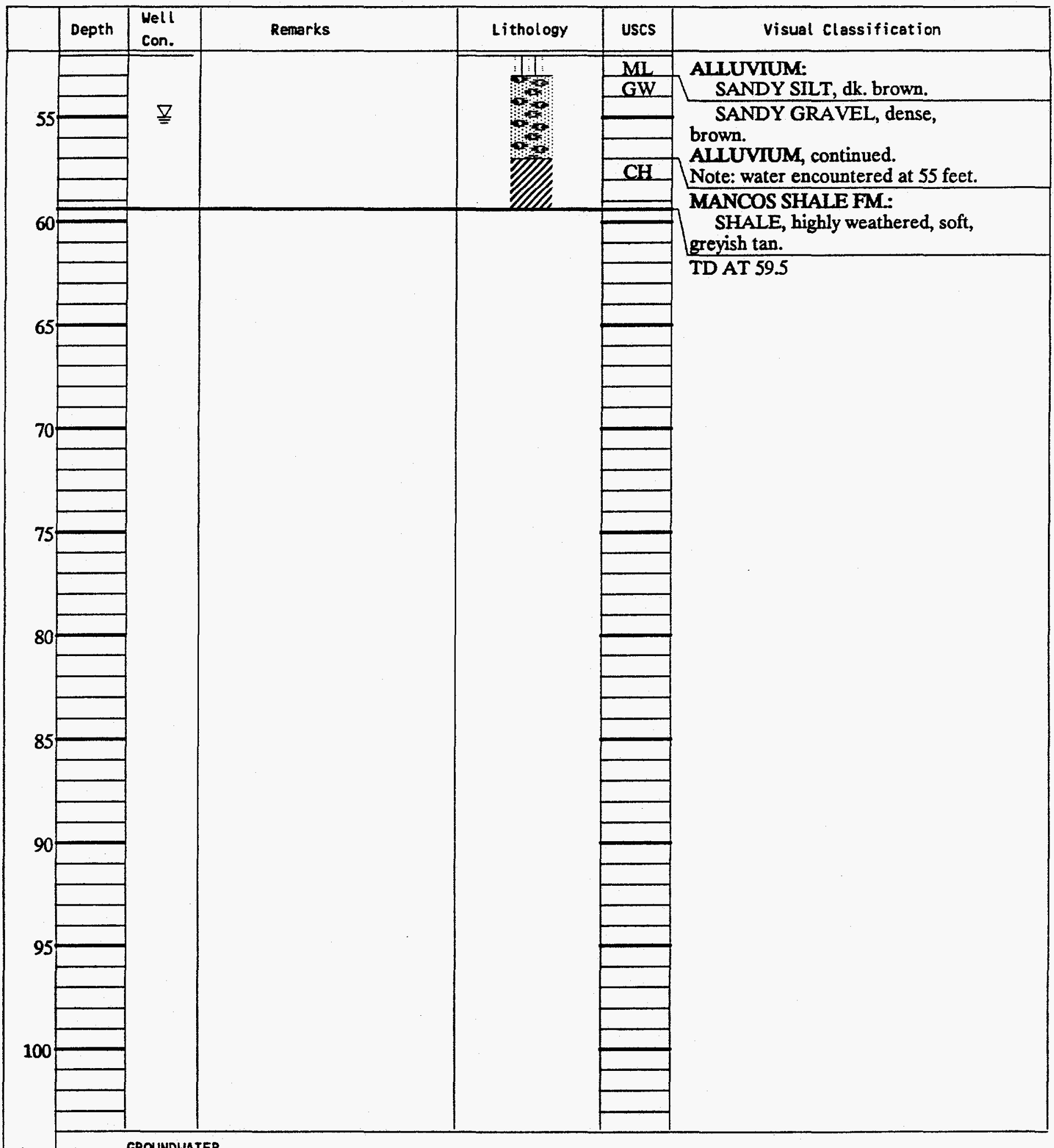

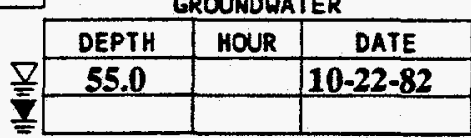


JOB NO. GRJ01

DEPTH OF SEAL

MELL CASING TYPE

COMPLETION
BORING TYPE

DATE $10 / 22 / 82$

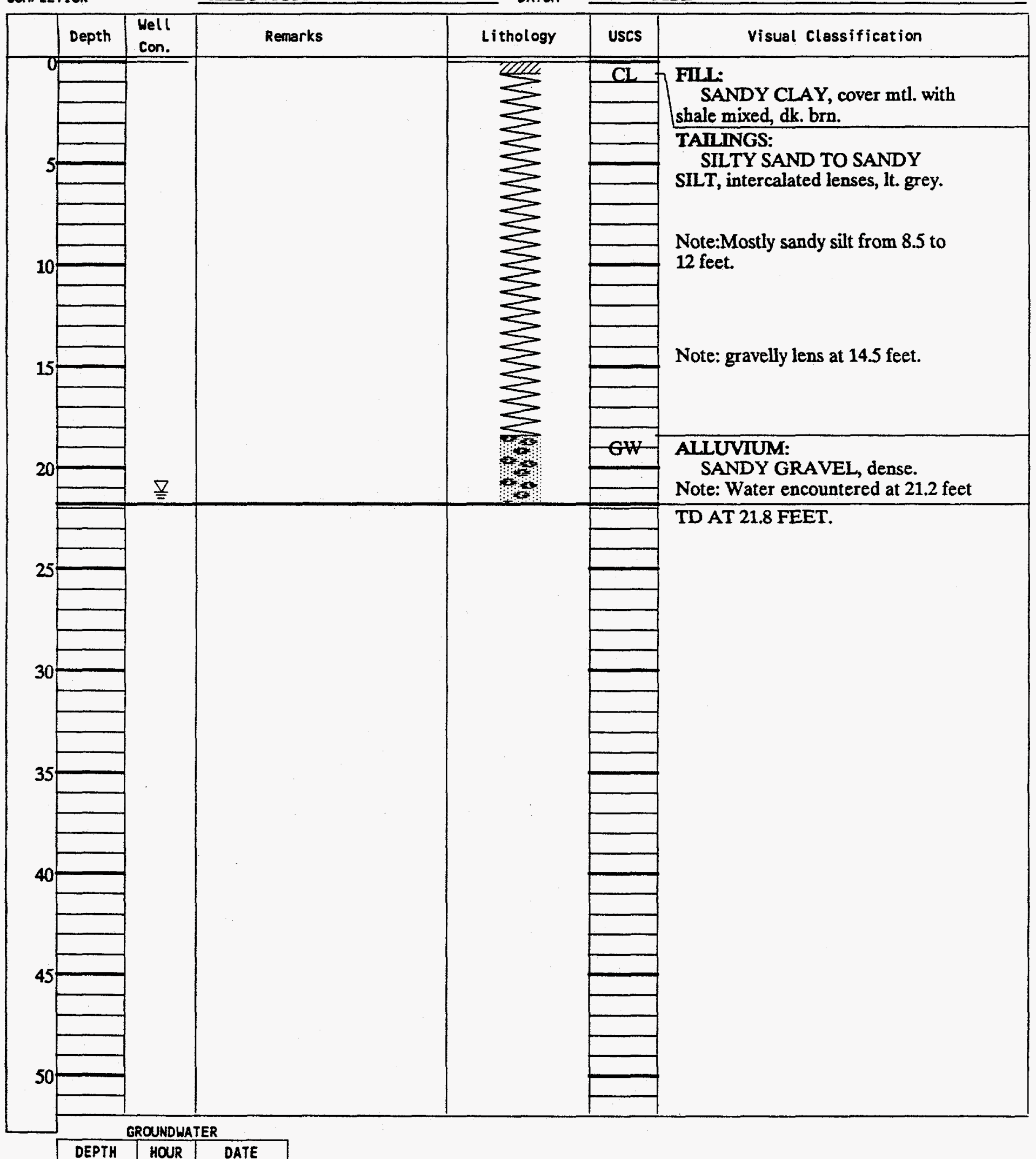

TOTAL DEPTH 21.8 feet

SURFACE ELEVATION $\quad \mathbf{4 5 7 9 . 8 0}$

LOCATION N 59845.70 E 33863.10

DATUM MSL
FIELD REP. UNK 
PROJECT GRAND JUNCTION PROCESS SITE

\begin{tabular}{|c|c|}
\hline JOB NO. GRJ01 & DATE $10 / 22 / 82$ \\
\hline BORING TYPE & UNK \\
\hline DEPTH OF SEAL & 18.40 \\
\hline WELL CASING TYPE & 2-IN. SCHED.40 PVC \\
\hline COMPLETIOH & ALLUVIUM \\
\hline
\end{tabular}

TOTAL DEPTH 22.0 feet

FIELD REP. UNK

SURFACE ELEVATION 4581.60

LOCATION N 5976730 E 32805.20

COMPLETIOH

DATUM MSL

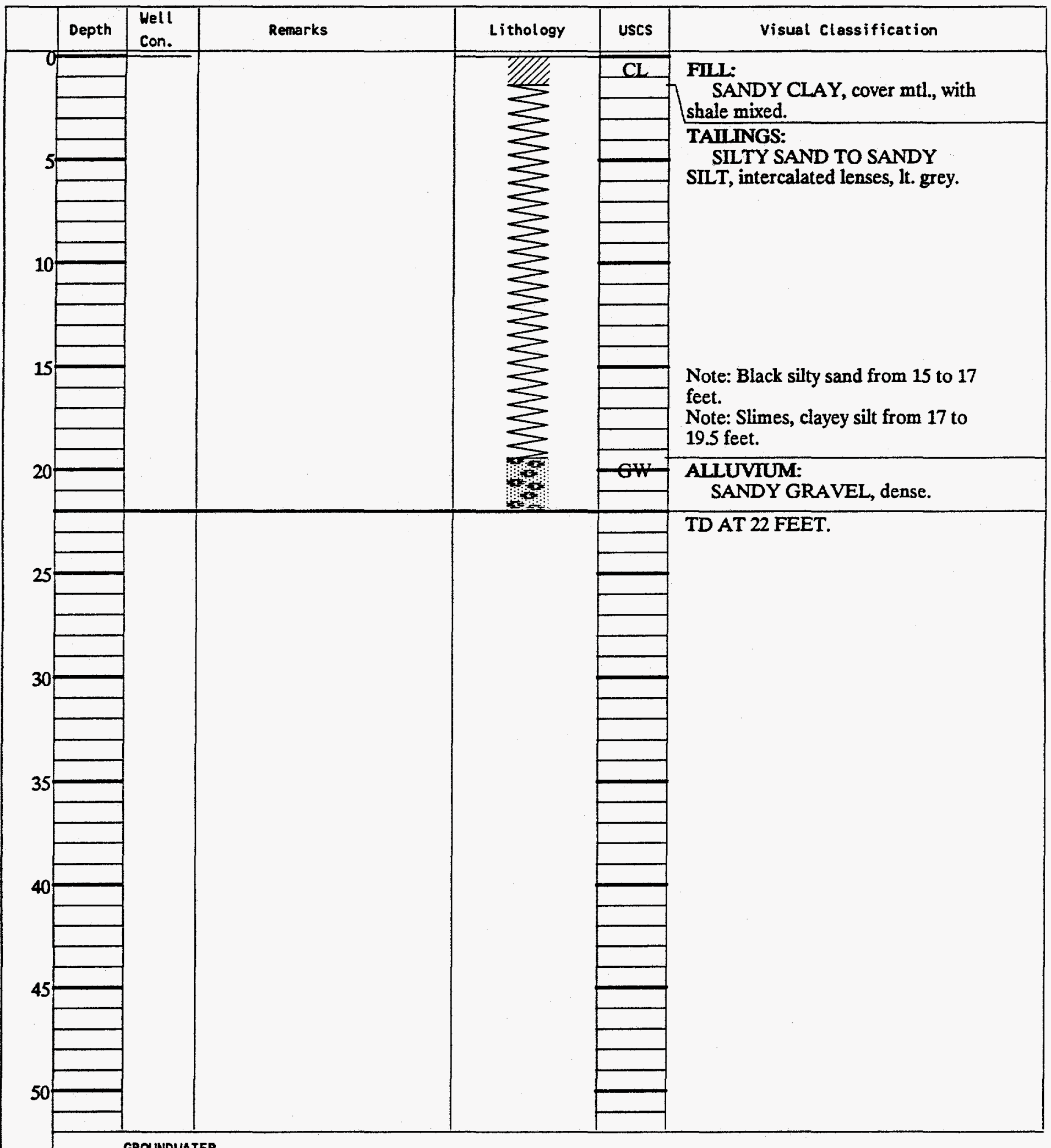

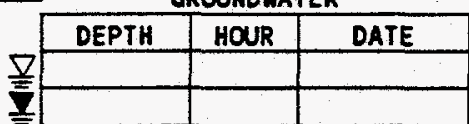


PROJECT GRAND JUNCTION PROCESS SITE

\begin{tabular}{ll} 
JOB NO. GRJ01 & \multicolumn{1}{c}{ DATE 10/22/82 } \\
BORING TYPE & UNK \\
DEPTH OF SEAL & 34.60 \\
WELL CASING TYPE & 2-IN. SCHED.40 PVC \\
COMPLETION & ALLUVIUM
\end{tabular}

\begin{tabular}{|c|c|c|}
\hline \multirow[b]{2}{*}{ Tिभal } & LOG OF WELL BORING NO. & 597 \\
\hline & 38.0 feet & \\
\hline FIELD REP. & UNK & \\
\hline SURFACE ELEY & 4596.70 & \\
\hline LOCATION & N $59530 . \overline{70}$ E 34098.00 & \\
\hline ITUM - & MSL & \\
\hline
\end{tabular}

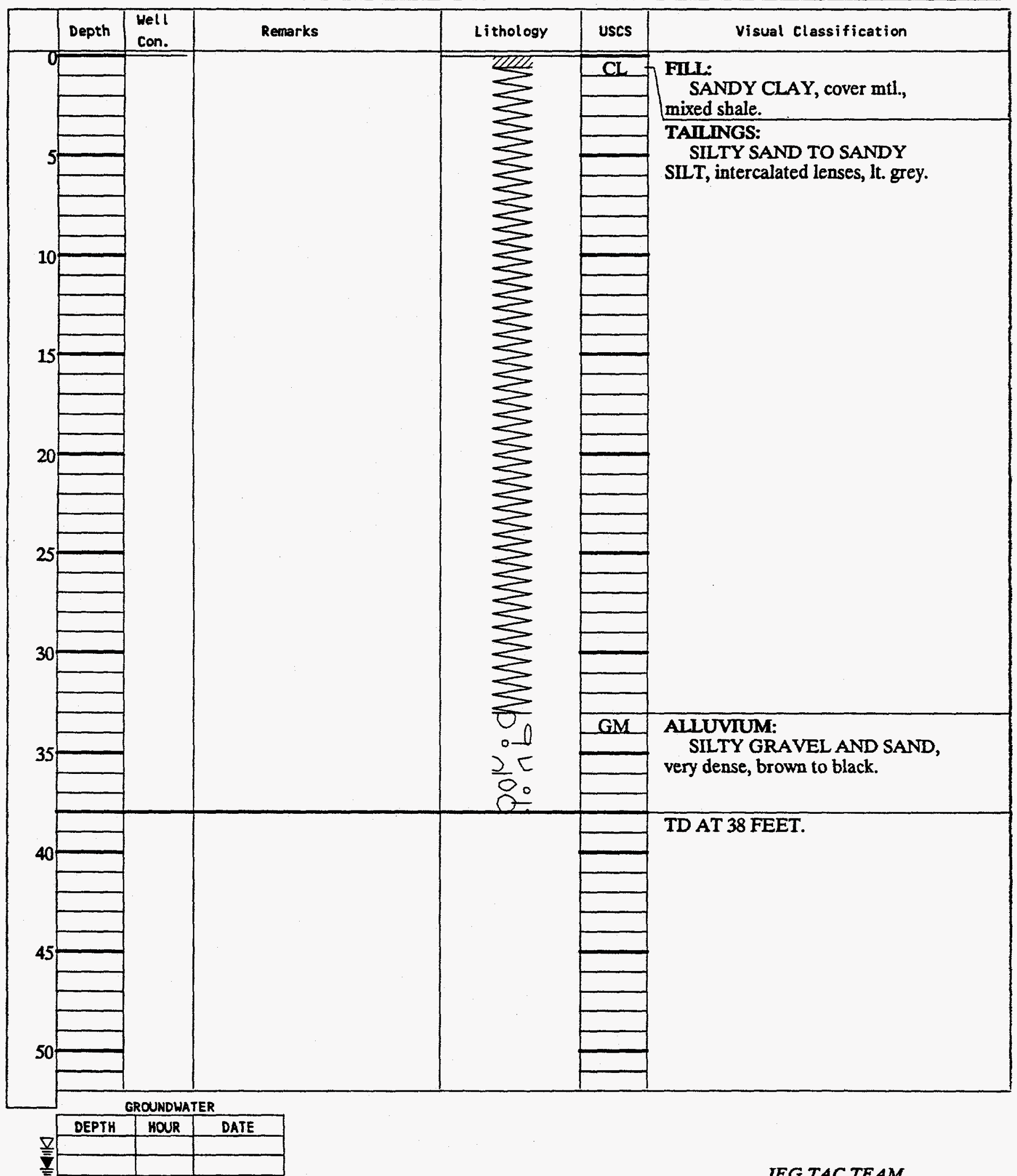


Jacobs Engineering

Albuquerque NM

DATE TIME

At printing SEP1495 15:20

Last update DEC1092 09:09

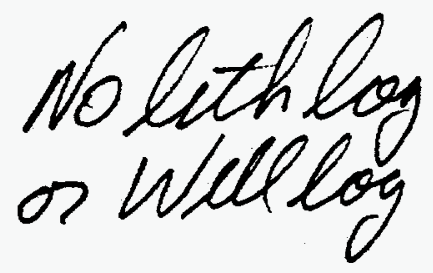

PROJECT ID GRJOI

POINT ID 631

Exploration Point Definition - ADDRESS 2201
$\{1$ DATES AND COORDINATES\}

MO DY YR

STARTED

ENDED

NORTH

EAST

ELEVATION

TREND NOO.OE PLUNGE -90.0
$\{2$ GENERAL INFORMATION SUPERVISOR

DRILLER

EQUIPMENT 2-IN. SCHED.40 PVC

METHOD

DEPTHS: Hole

STARTING PAGE
HOLE DIA 6.2-IN

2

$\{3$ NOTES

ALLUVIUM

ADDITIONAL NOTE

$\{4$ POINT DESCRIPTOR CODES

TYPE 1

TYPE 2
LOCATION 140.9

LOCATION 2
\{5 ADDITIONAL DESCRIPTORS

PT.DESC1

PT.DESC2
PT.DESC3

PT.DESC 4 


\section{No lithely}

Jacobs Engineering

Albuquerque NM

$\begin{array}{lll} & \text { DATE } & \text { TIME } \\ \text { At printing } & \text { SEP1495 } & 15: 20 \\ \text { Last update } & \text { DEC1092 } & 14: 27\end{array}$

PROJECT ID GRJOI

POINT ID 633

Exploration Point Definition - ADDRESS 2201

$\{1$ DATES AND COORDINATES $\}$

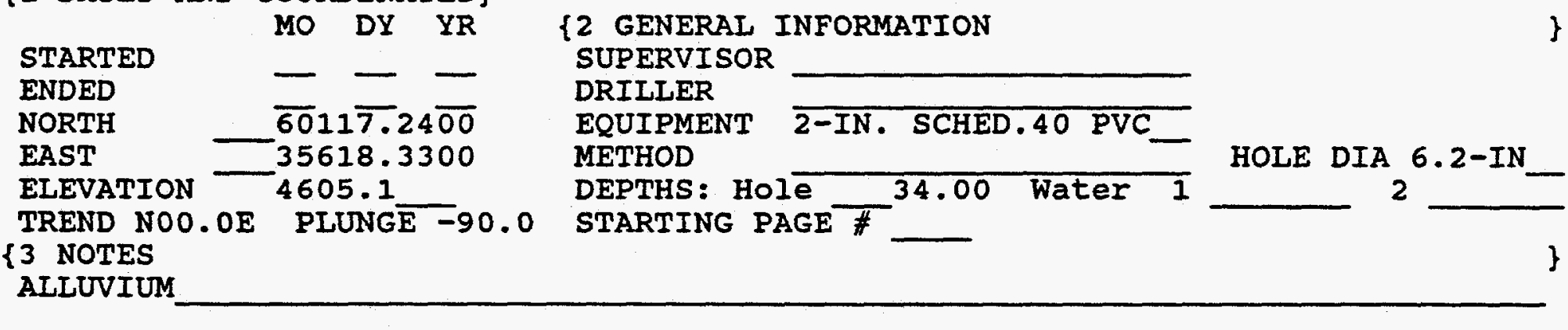

ADDITIONAL NOTE

$\{4$ POINT DESCRIPTOR CODES

TYPE 1

TYPE 2
LOCATION

LOCATION 133.9

2
\{5 ADDITIONAL DESCRIPTORS

PT.DESC1

PT.DESC2
PT.DESC3

PT.DESC4 
Jacobs Engineering

Albuquerque NM

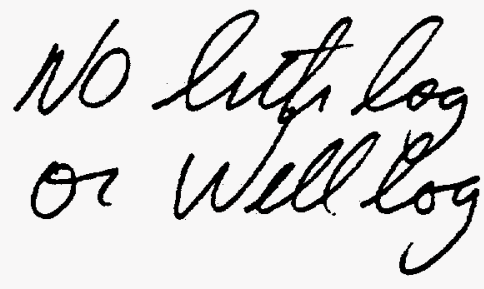

At printing

Last update DEC1092 14:29

PROJECT ID GRJO1

POINT ID 634

Exploration Point Definition - ADDRESS 2201

$\{1$ DATES AND COORDINATES \}

MO DY YR

STARTED

ENDED

NORTH

EAST

ELEVATION

TREND NOO.OE

$\{3$ NOTES

ALLUVIUM $\overline{60117.33 \overline{00}}$

35332.3000

PLUNG $\bar{E}-90.0$
4607.6
\{2 GENERAL INFORMATION SUPERVISOR

DRILLER

EQUIPMENT 2-IN. SCHED.40 PVC

METHOD

DEPTHS : Hole

STARTING PAGE
ADDITIONAL NOTE

\{4 POINT DESCRIPTOR CODES

TYPE 1

TYPE 2
LOCATION 138.9

LOCATION 2
\{5 ADDITIONAL DESCRIPTORS

PT.DESC1

PT.DESC2
PT.DESC3

PT.DESC4
HOLE DIA $6.2-I N$ 2 
Albuquerque NM

\section{DATE TIME}

At printing SEP1495 15:21

Last update DEC1092 14:30
Jacobs Engineering

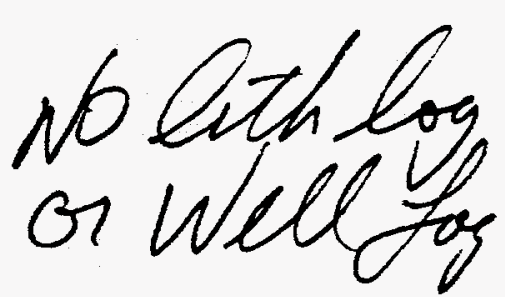

PROJECT ID GRJ01

POINT ID 635

Exploration Point Definition - ADDRESS 2201

\section{$\{1$ DATES AND COORDINATES\}}

MO DY YR

\section{STARTED}

ENDED

TREND NOO.OE PLUNG $\bar{E}-90.0$
$\{2$ GENERAL INFORMATION SUPERVISOR

DRILLER

METHOD

DEPTHS: Hole

STARTING PAGE
EQUIPMENT 2-IN. SCHED.40 PVC_
NORTH

EAST

ELEVATION

$\overline{59} 92 \overline{5.12 \overline{00}}$

35444.9000

4615.6

$\{3$ NOTES

ALLUVIUM
ADDITIONAL NOTE

\{4 POINT DESCRIPTOR CODES

TYPE 1 TYPE 2
LOCATION 141.8

LOCATION 2
$\{5$ ADDITIONAL DESCRIPTORS

PT.DESCI

PT.DESC3

PT.DESC2
HOLE DIA $6.2-$ IN

2 
JOB NO. GRJ01 DATE

BORING TYPE

DEPTH OF SEAL

VELL CASING TYPE

COMPLETION

conterton

\begin{tabular}{|l|l|l|l|l}
\hline & Depth & $\begin{array}{l}\text { Well } \\
\text { Con. }\end{array}$ & Remarks & Lith \\
\hline
\end{tabular}

TOTAL DEPTH $\mathbf{4 0 . 0 \text { feet }}$

FIELD REP. UNK

SURFACE ELEVATION

LOCATION

DATUM

4574.35

N 59541.50 E 36658.10

MSL
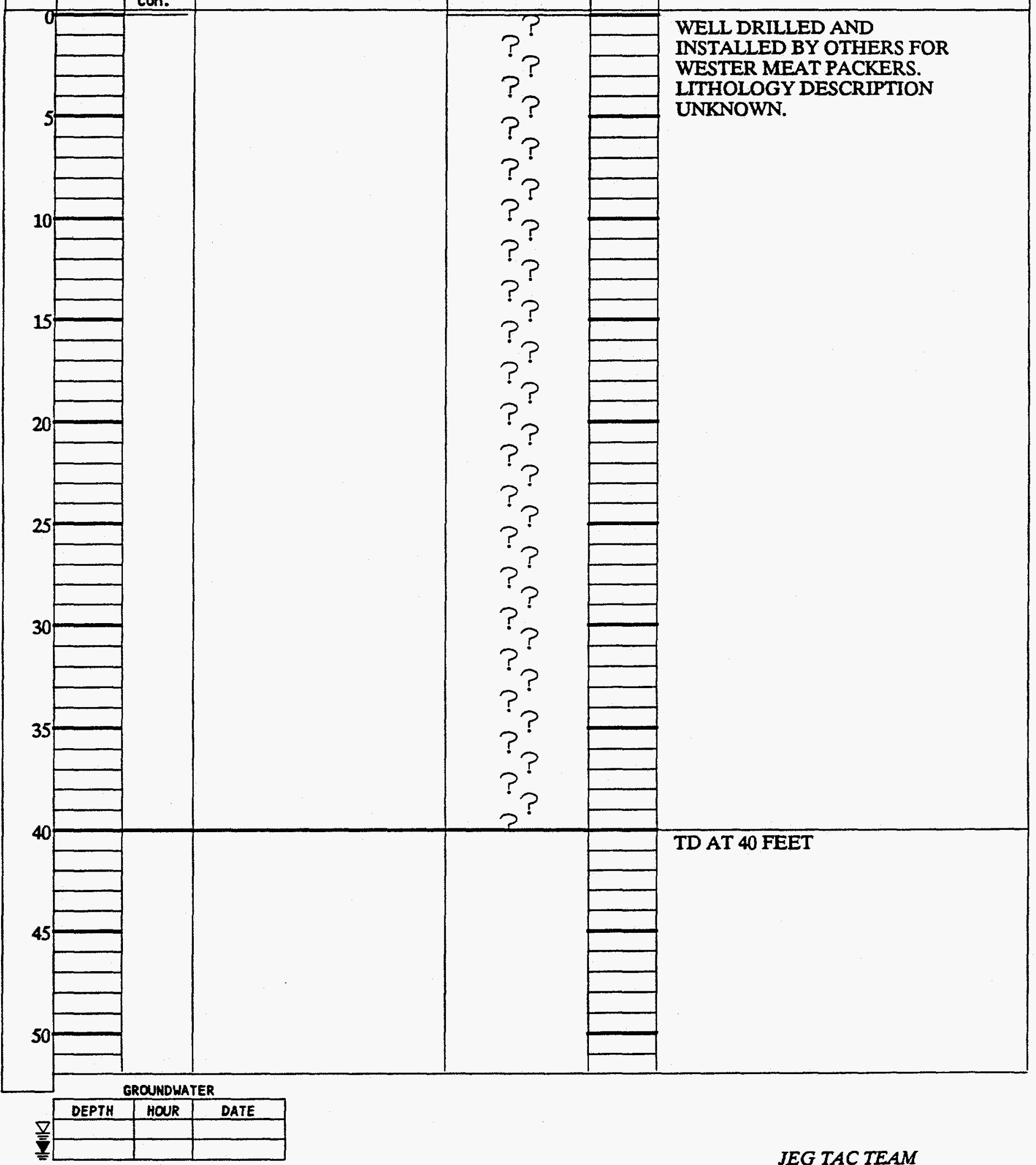
JOB NO. GRJ01

DATE $\quad 09 / 14 / 77$

BORING TYPE

DEPTH OF SEAL

VELL CASING TYPE COMPLETION
COMPLETION

\begin{tabular}{|l|l|l|l|l|}
\hline & Depth & $\begin{array}{l}\text { Mell } \\
\text { Con. }\end{array}$ & Remarks & L \\
\hline
\end{tabular}

Details of the well installation for this borehole are not available.

The method of drilling is also unknown.

The well was installed

by "REC" (?). Depth of casing is measured at 23.5 feet, with one ft. stickup.

TOTAL DEPTH 23.5 feet

FIELD REP.

SURFACE ELEVATION 4600.00

LOCATION N 58650.00 E 49280.00

DATUM MSL
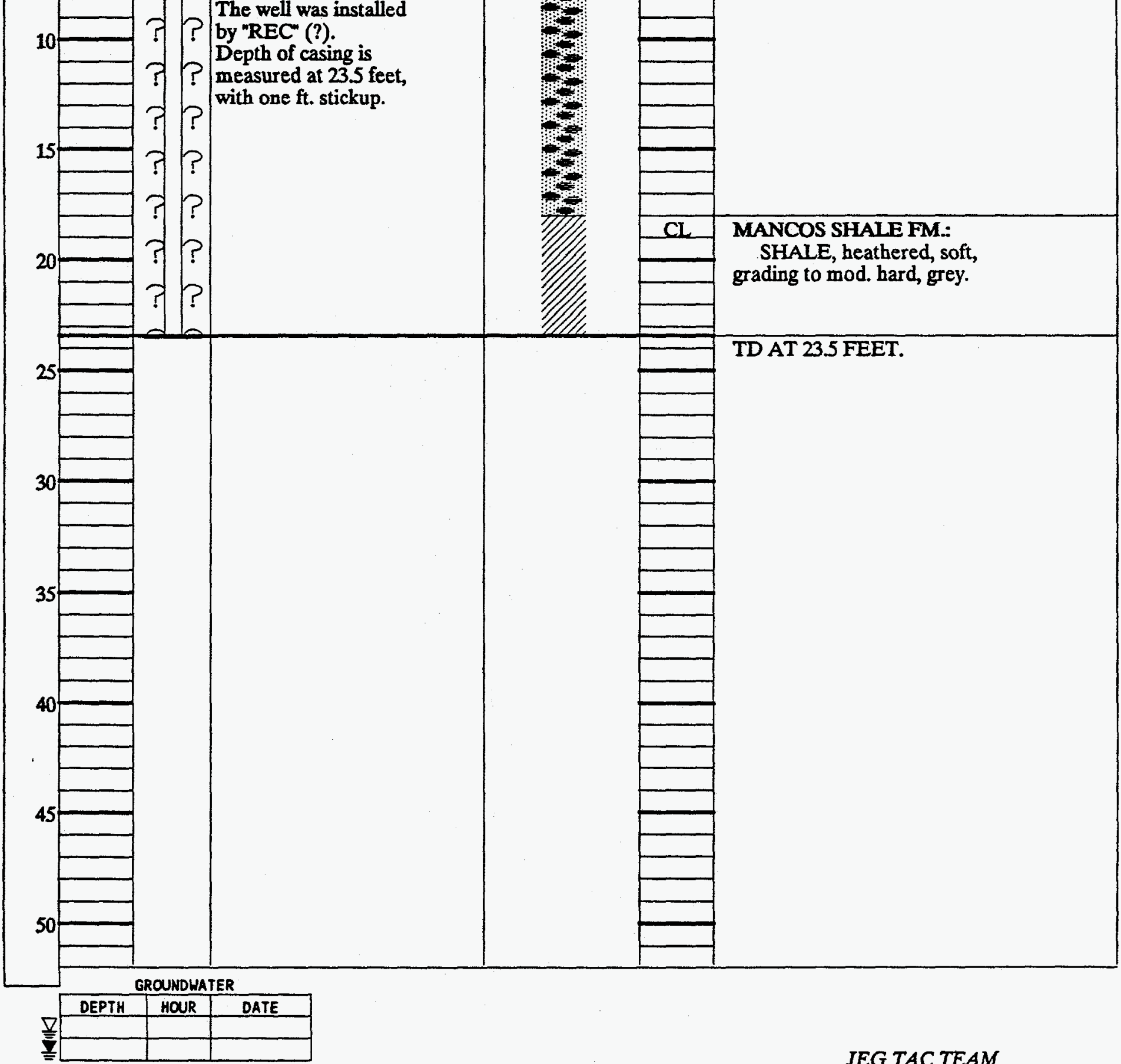
PROJECT GRAND JUNCTION PROCESS SITE

JOB NO. GRJ01
BORING TYPE
DEPTH OF SEAL
MELL CASING TYPE
COMPLETION

TOTAL DEPTH 34.0 feet

FIELD REP.

SURFACE ELEVATION $\quad 4608.00$

COMPLETION

LOCATION N 60780.00 E 49410.00

DATUM MSL

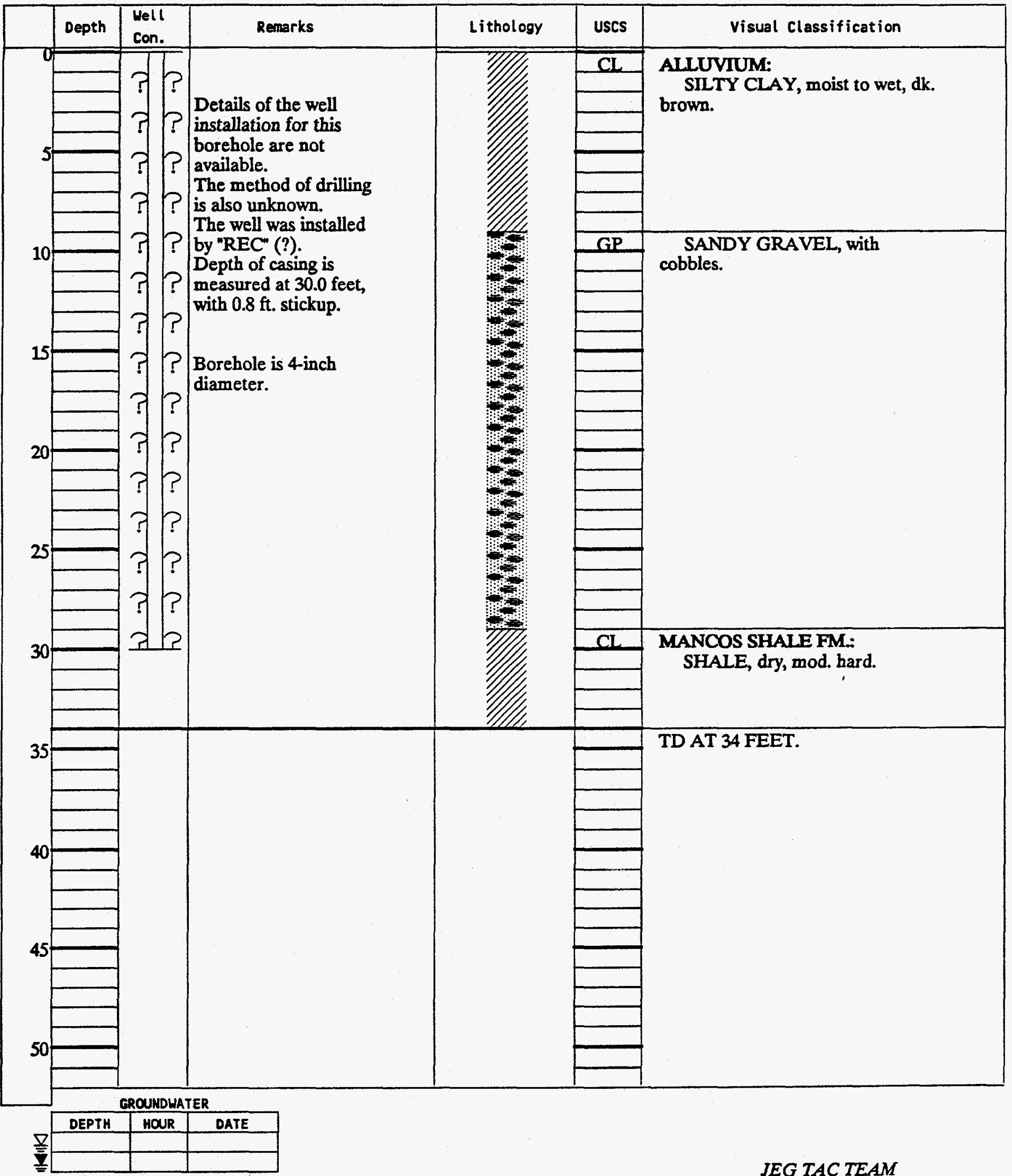


PROJECT GRAND JUNCTION PROCESS SITE

Page

1 of 1

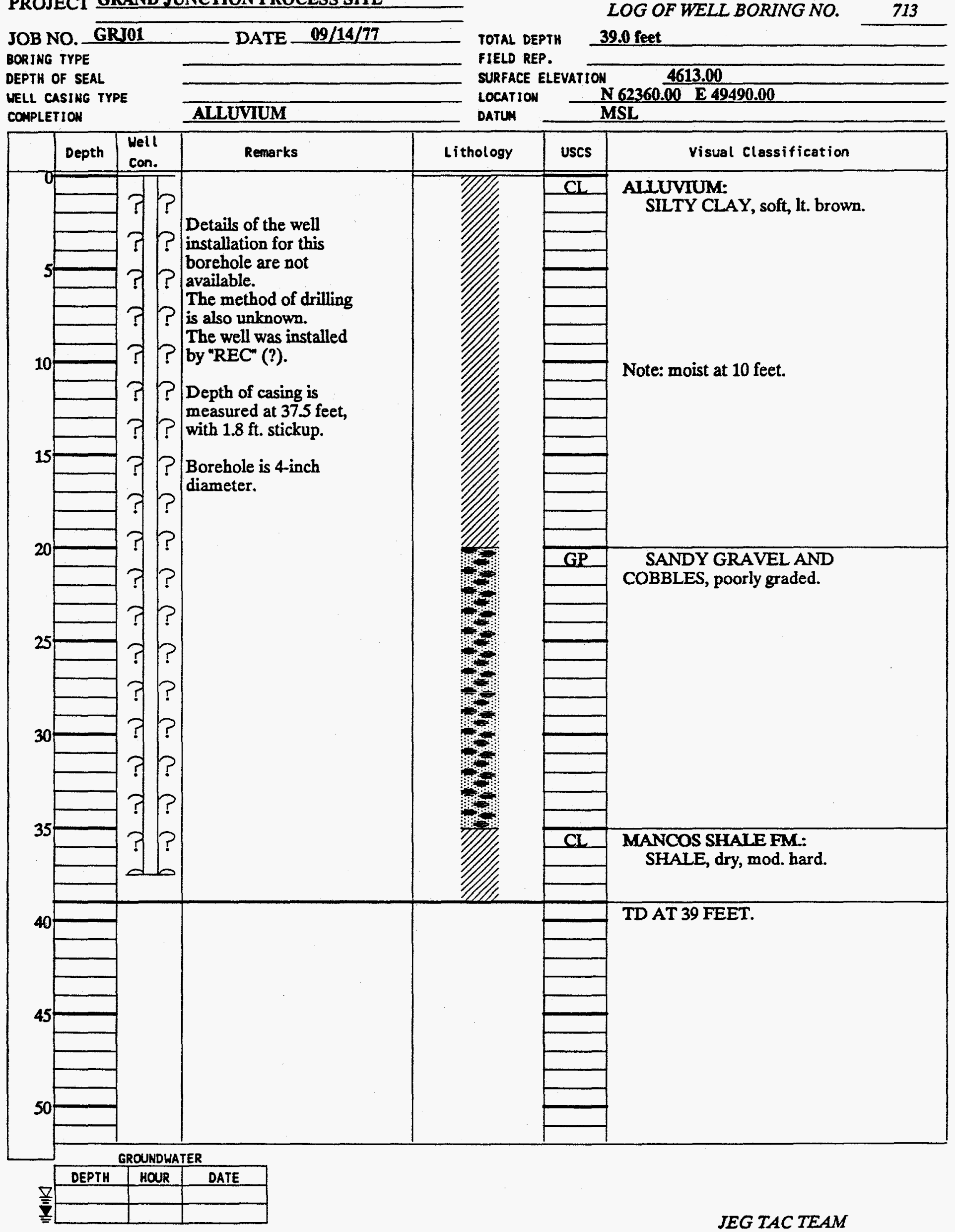


PROJECT GRAND JUNCTION PROCESS SITE

Page 1 of 1

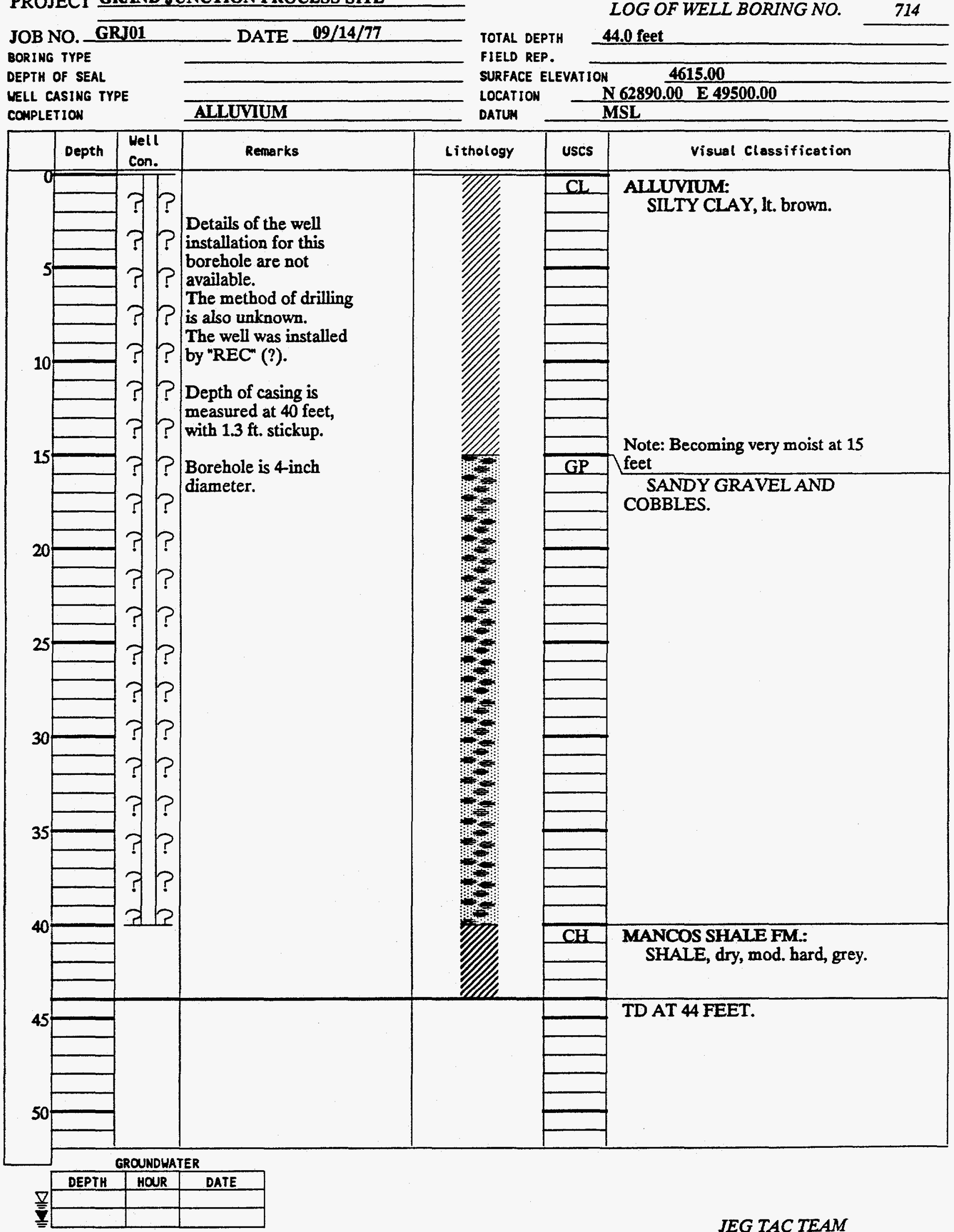




\section{PROJECT GRAND JUNCTION PROCESS SITE}

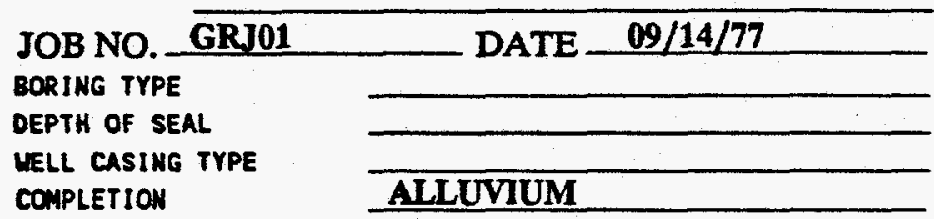

Page 1 of 2 LOG OF WELL BORING NO.

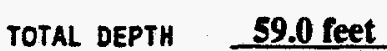

FIELD REP.

SURFACE ELEVATION $\quad \mathbf{4 6 3 0 . 0 0}$

LOCATION N 64980.00 E 49580.00

DATUM MSL

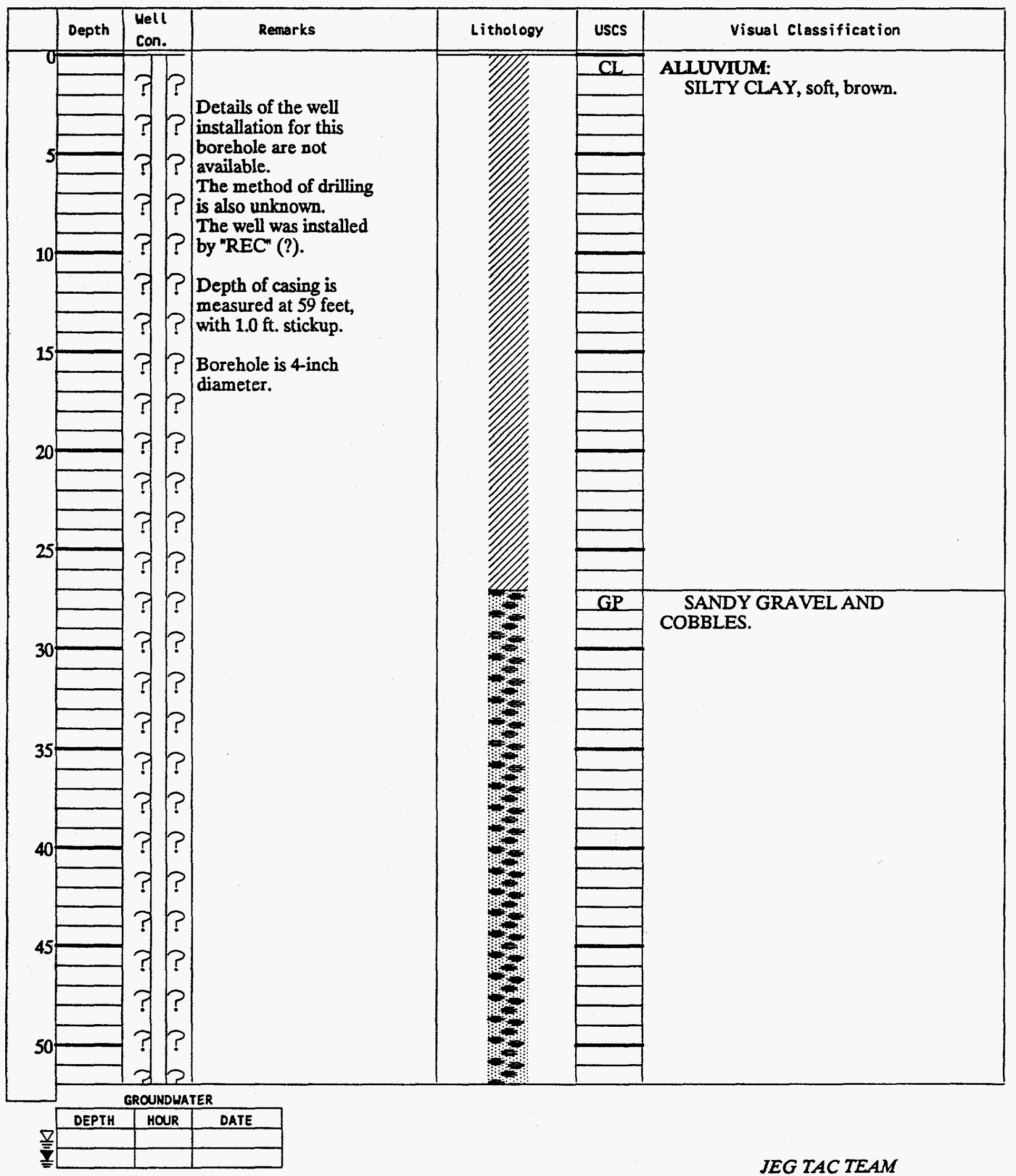


PROJECT GRAND JUNCTION PROCESS SITE

$\begin{array}{ll}\text { JOB NO. GRJ01 } & \\ \text { BORING TYPE } & \text { DATE } 09 / 14 / 77 \\ \text { DEPTH OF SEAL } & \\ \text { MELL CASIMG TYPE } & \\ \text { COMPLETION } & \text { ALLUVIUM }\end{array}$

COMPLETION

Page 2 of 2
LOG OF WELL BORING NO.

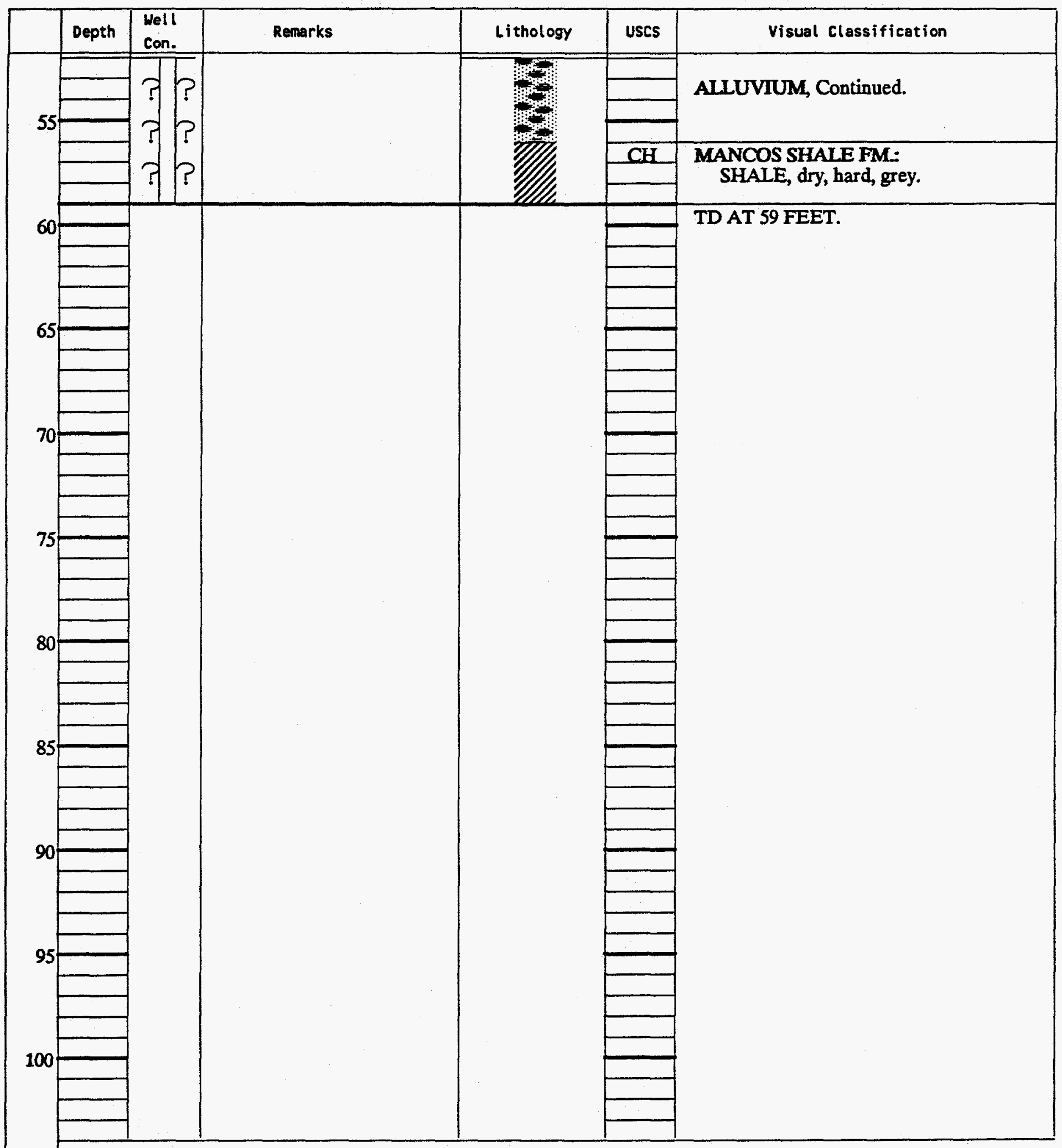

TOTAL DEPTH $\mathbf{5 9 . 0 \text { feet }}$

FIELD REP.

SURFACE ELEVATION $\mathbf{4 6 3 0 . 0 0}$

LOCATION N $\quad$ N4980.00 E 49580.00

OATUM MSL 


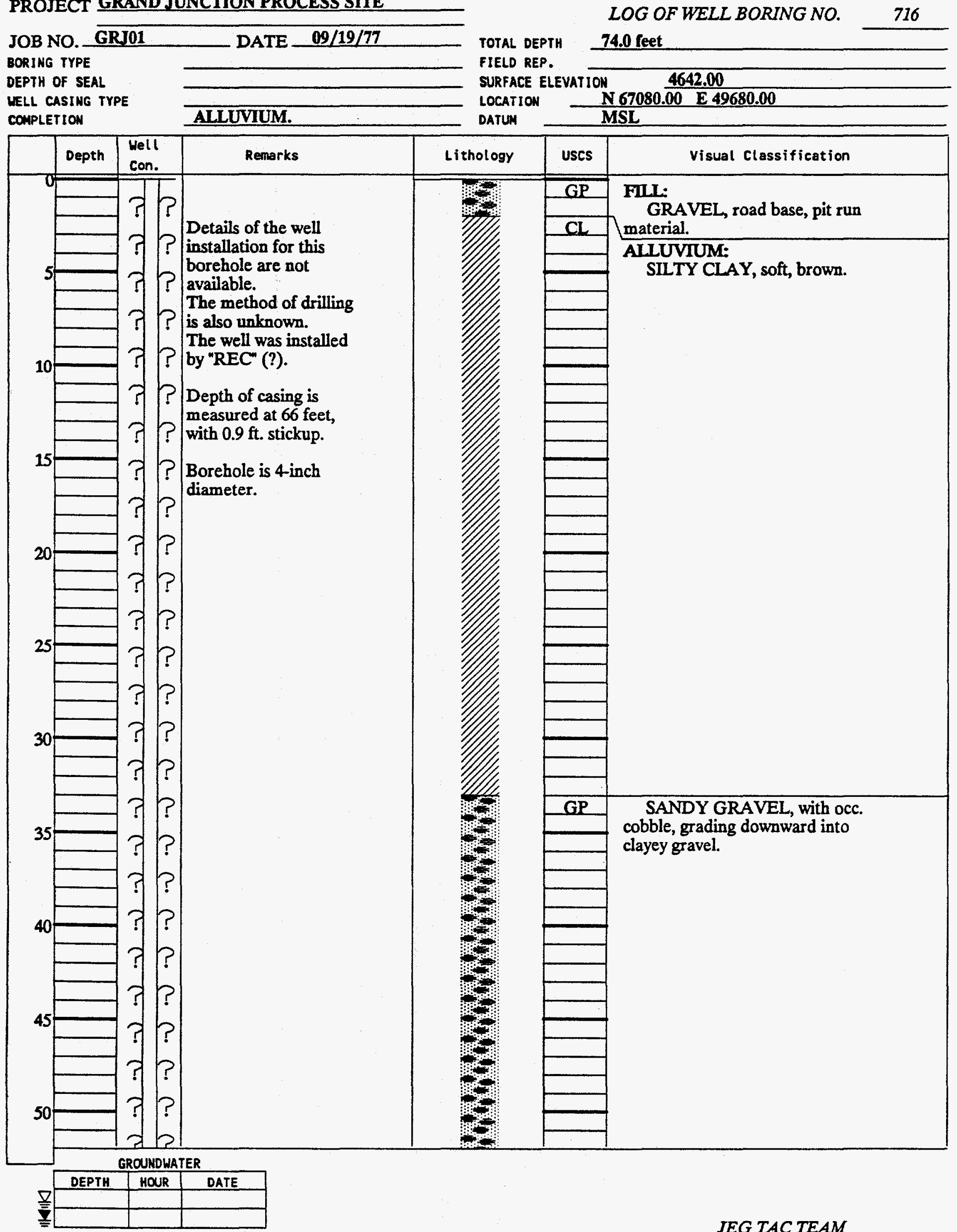




\section{PROJECT GRAND JUNCTION PROCESS SITE}

JOB NO. GRJ01

BORING TYPE

DEPTH OF SEAL

WELL CASING TYPE

COMPLETION

copth
DATE $\quad 09 / 19 / 77$

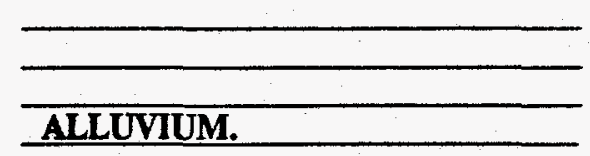

TOTAL DEPTH $\mathbf{7 4 . 0 \text { feet }}$

FIELO REP.

SURFACE ELEVATION 4642.00

LOCATION N 67080.00 E 49680.00

DATUM MSL

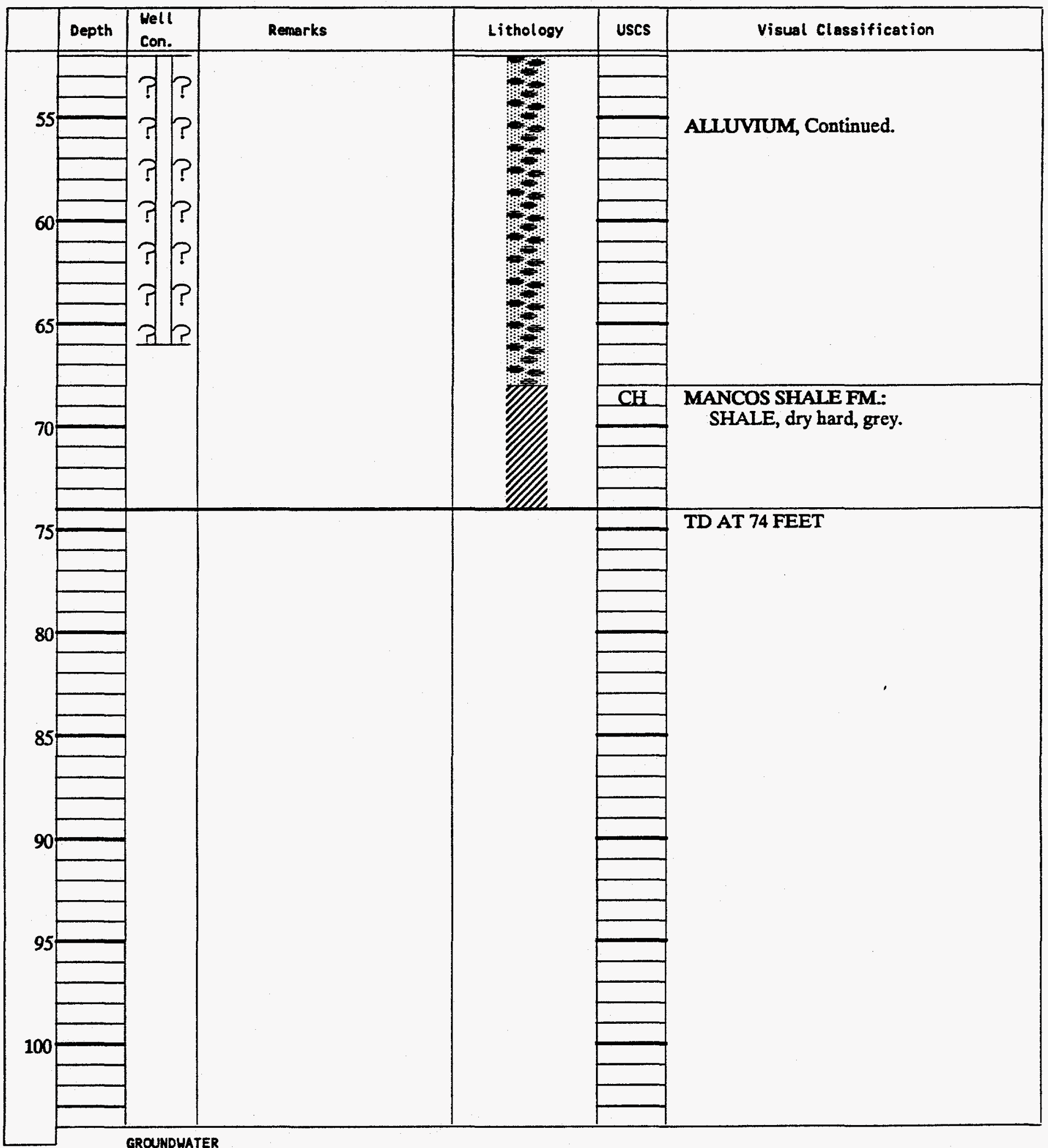

GROUNDHATER

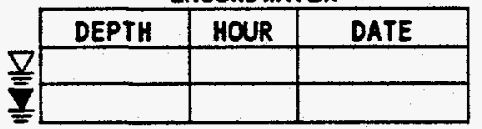


Page 1 of 2

JOB NO. GRJ01

BORING TYPE

DEPTH OF SEAL

MELL CASING TYPE COMPLETION
DATE $09 / 20 / 77$

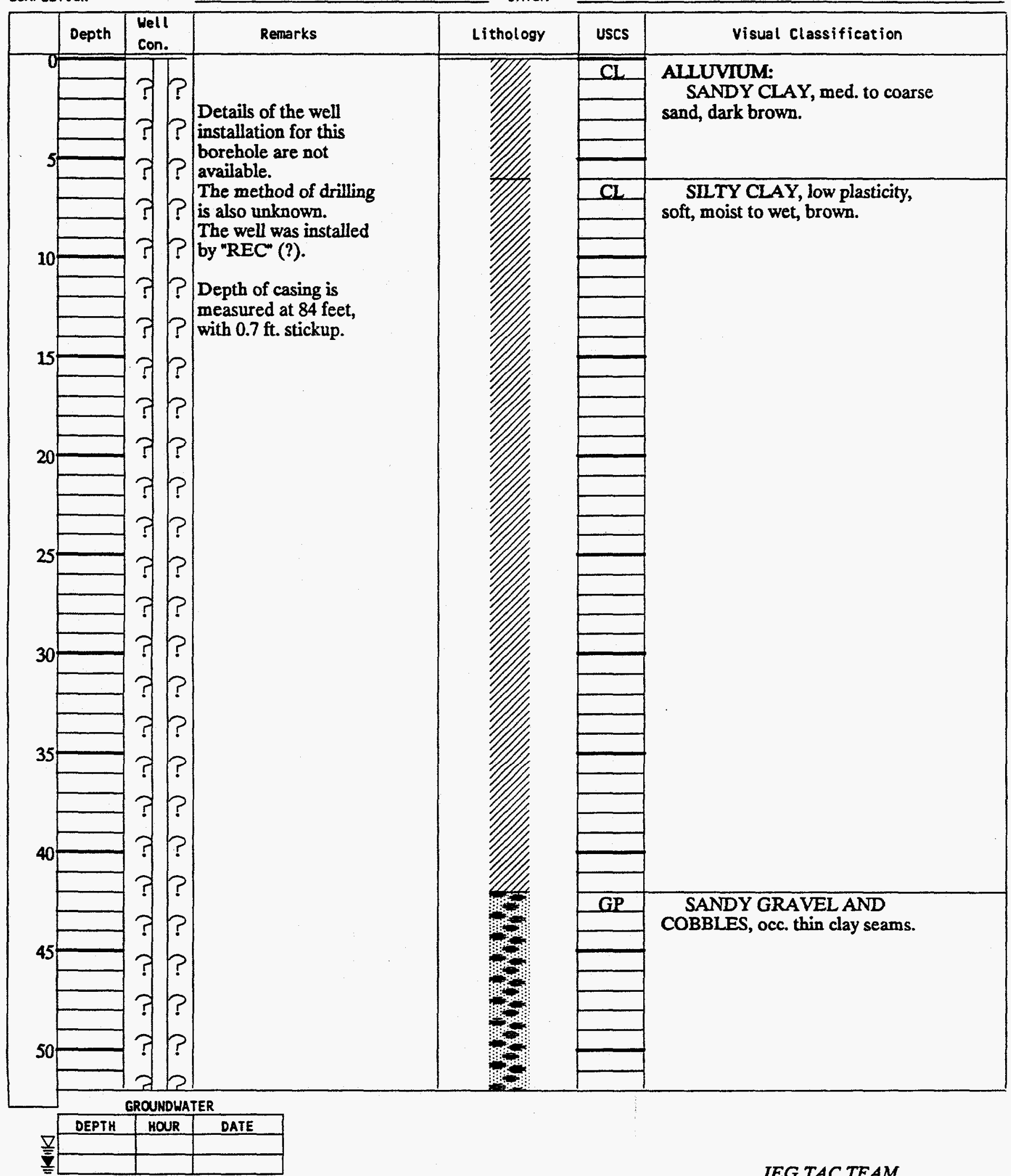

TOTAL DEPTH 84.0 feet

FIELD REP.

SURFACE ELEVATION $\quad \mathbf{4 6 6 0 . 0 0}$

LOCATION

DATUM
N 68650.00 E 49700.00

MSL 


\section{PROJECT GRAND JUNCTION PROCESS SITE}

JOB NO. GRJ01

BORING TYPE

DEPTH OF SEAL

WELL CASING TYPE

COMPLETION
DATE 09/20/77

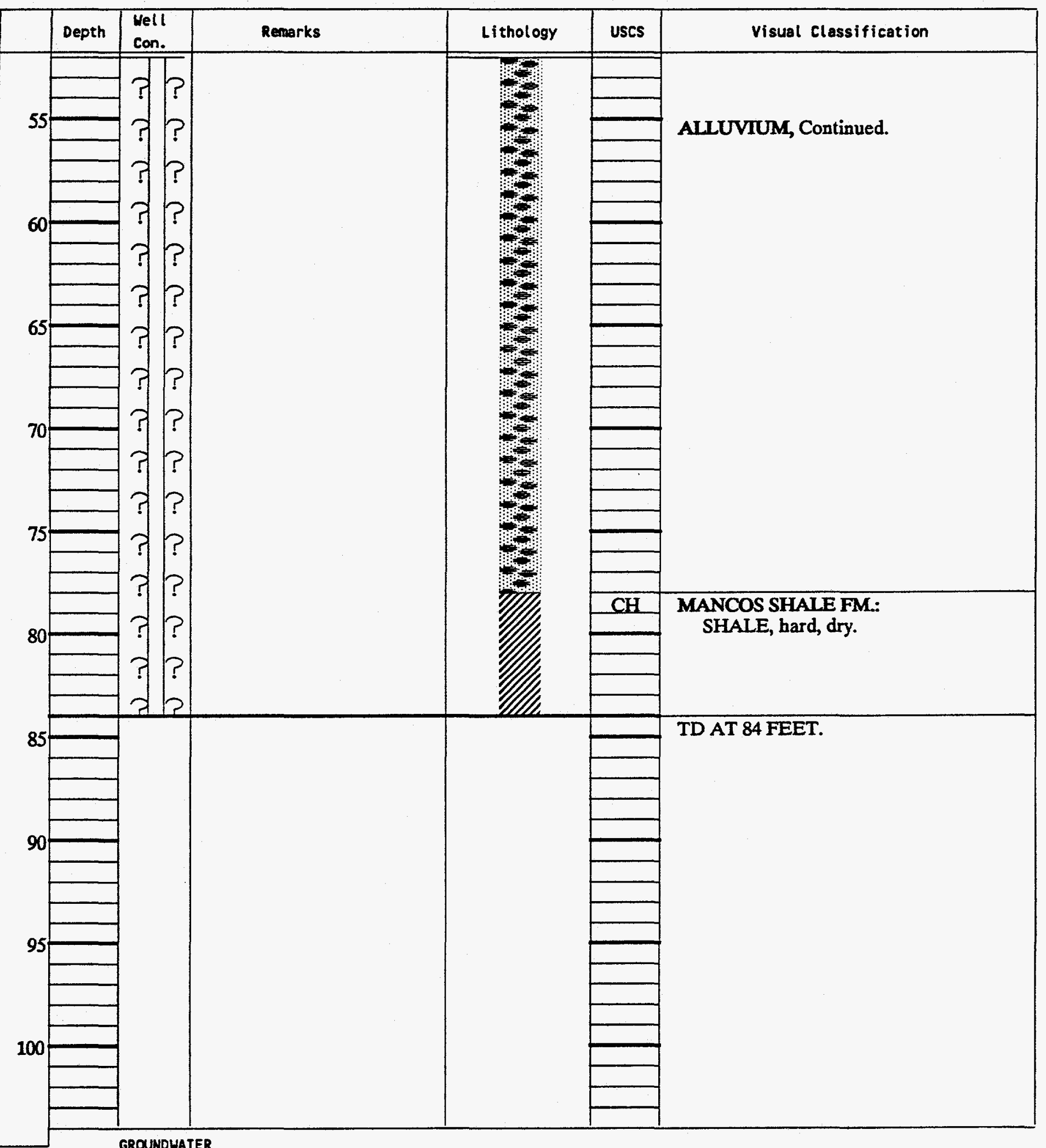

TOTAL DEPTH $\quad 84.0$ feet

FIELD REP.

SURFACE ELEVATION $\quad 4660.00$

LOCATION N 68650.00 E 49700.00

DATUM MSL
LOG OF WELL BORING NO. 
PROJECT GRAND JUNCTION PROCESS SITE

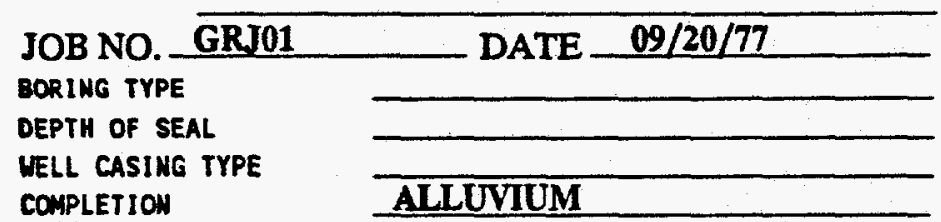

Page 1 of 2 LOG OF WELL BORING NO. 718

TOTAL DEPTH 74.5 feet

FIELD REP.

SURFACE ELEVATION $\quad \mathbf{4 6 7 0 . 0 0}$

LOCATION N $70770.00 \quad \mathbf{4} 49750.00$ DATUM MSL

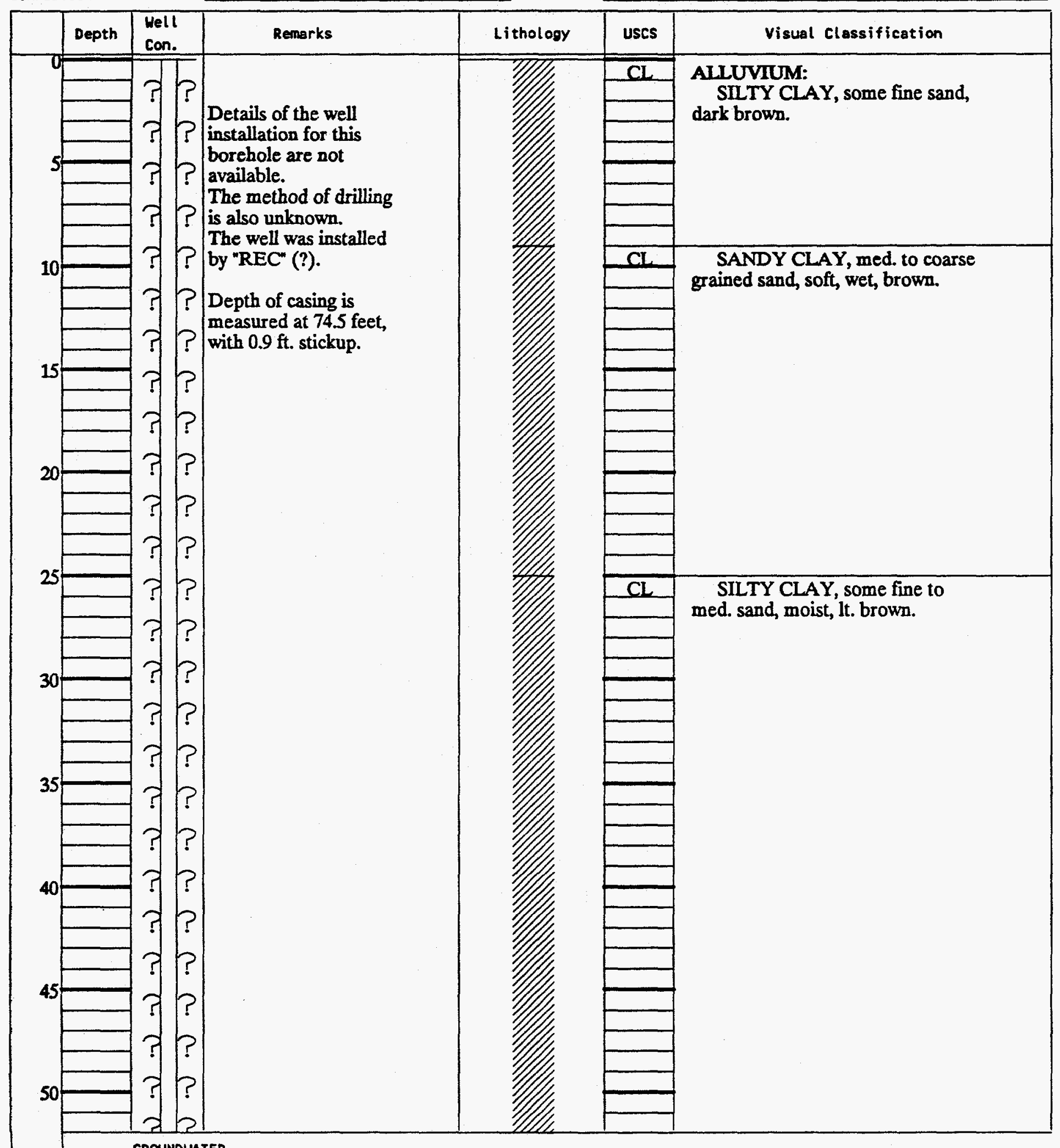

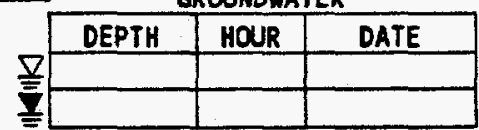


PROJECT GRAND JUNCTION PROCESS SITE

JOB NO. GRJ01

BORING TYPE

DEPTH OF SEAL

CONPLETION

DATE 09/20/77
WELL CASING TYPE

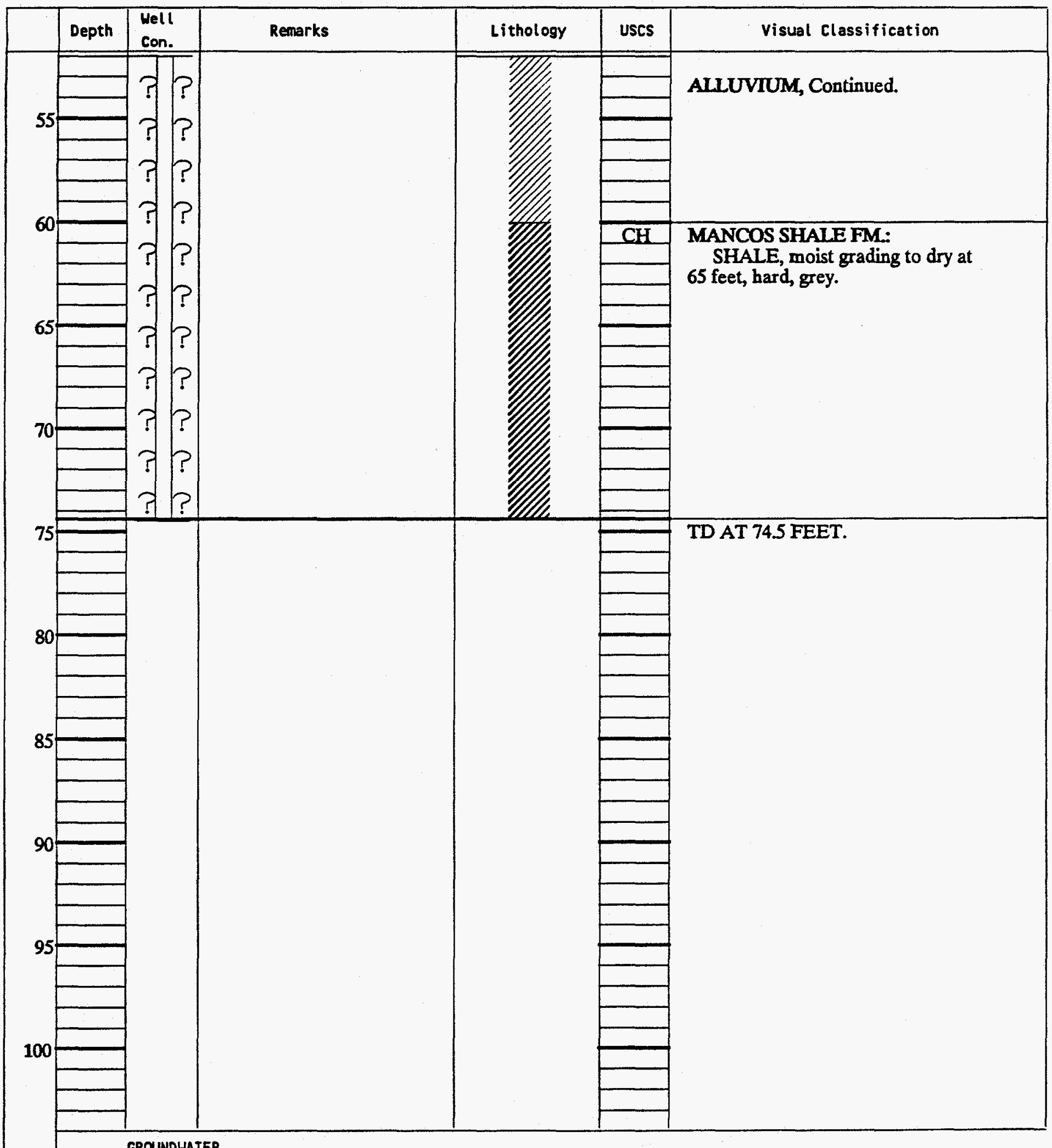

GROUNDHATER

TOTAL DEPTH 74.5 feet

FIELD REP.

SURFACE ELEVATION $\quad \mathbf{4 6 7 0 . 0 0}$

LOCATION

N 70770.00 E 49750.00

MSL

ANCOS SHALE FM:

SHALE, moist grading to dry a

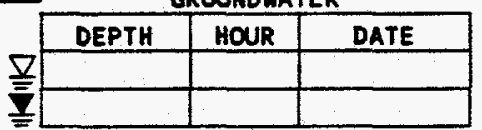


PROJECT GRAND JUNCTION PROCESS SITE

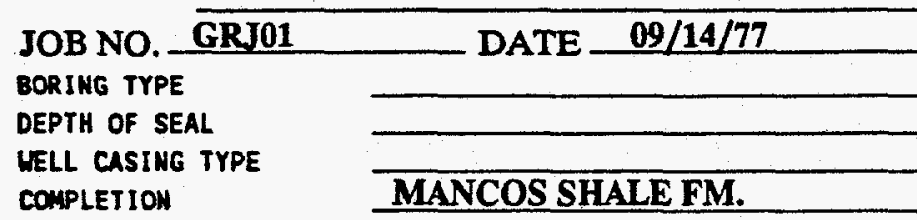

Page 1 of 2

LOG OF WELL BORING NO. 719
TOTAL DEPTH 60.5 feet

FIELD REP.

SURFACE ELEVATION $\quad \mathbf{4 6 8 0 . 0 0}$

LOCATION N 72360.00 E 49800.00

DATUM MSL

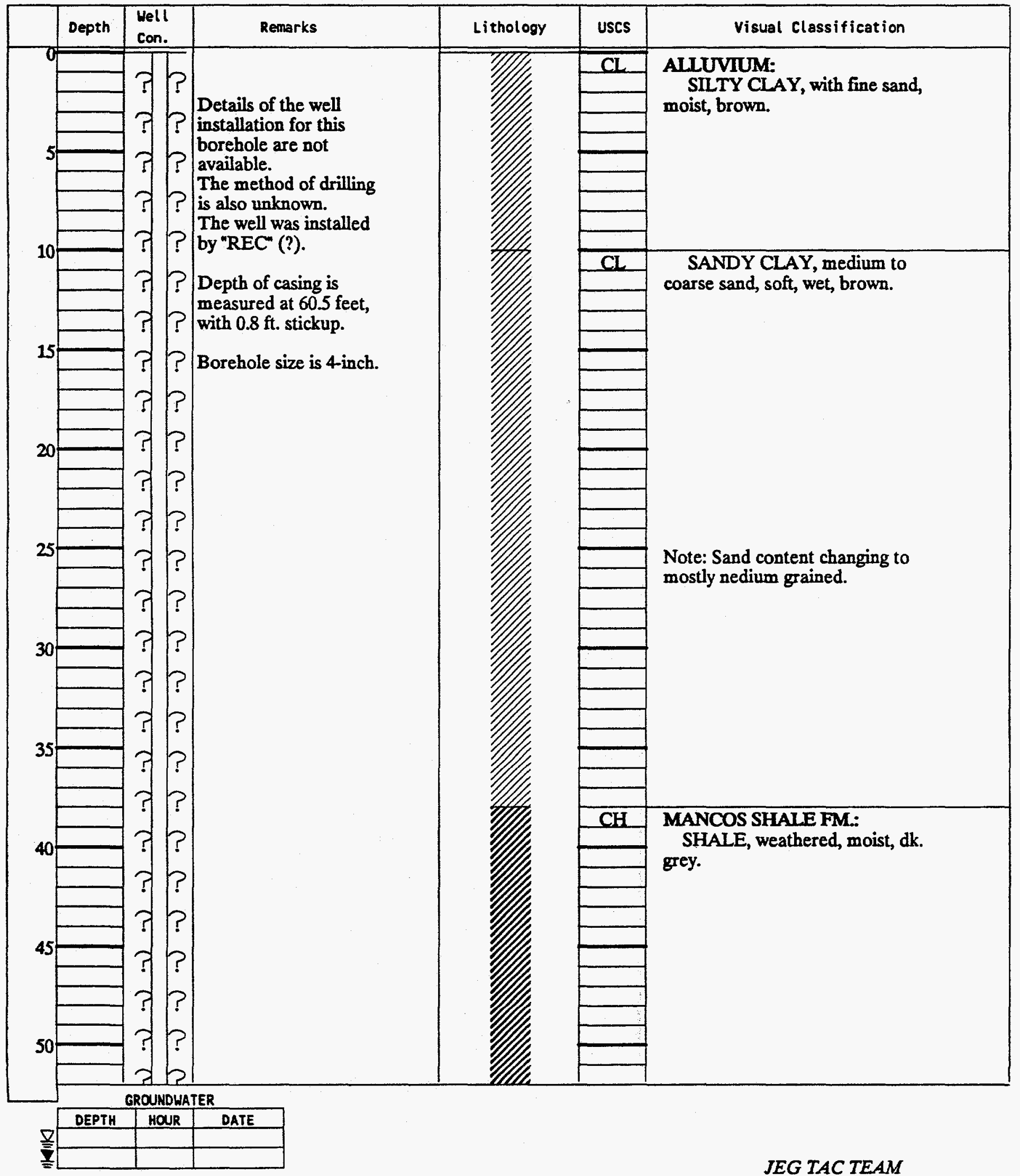


PROJECT GRAND JUNCTION PROCESS SITE

JOB NO. GRJ01

BORING TYPE

DEPTH OF SEAL

COMPLETION

DATE 09/14/77
MELL CASING TYPE

\begin{tabular}{|l|l|l|l|l}
\hline & Depth & Well & Remarks & Lithol \\
\hline
\end{tabular}

Page 2 of 2 LOG OF WELL BORING NO.

TOTAL DEPTH 60.5 feet

FIELD REP.

SURFACE ELEVATION $\quad 4680.00$

LOCATION N 72360.00 E 49800.00

DATUM
MSL

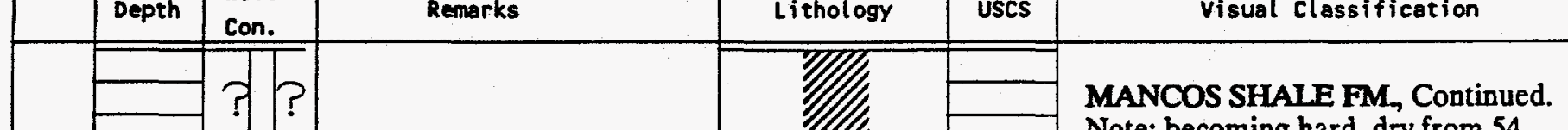

Note: becoming hard, dry from 54

feet.

\section{TD AT 60 FEET.}

ए
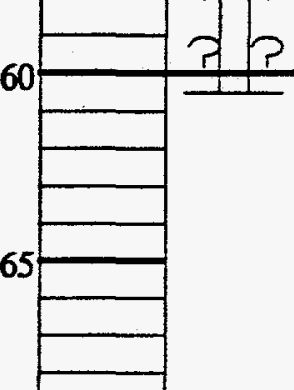

70

75

80



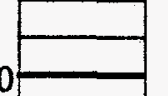

ए

85

85

-

品

90

0

\begin{tabular}{|}
\hline \\
\hline \\
\hline
\end{tabular}

95

5

$\square$

100

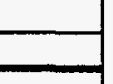
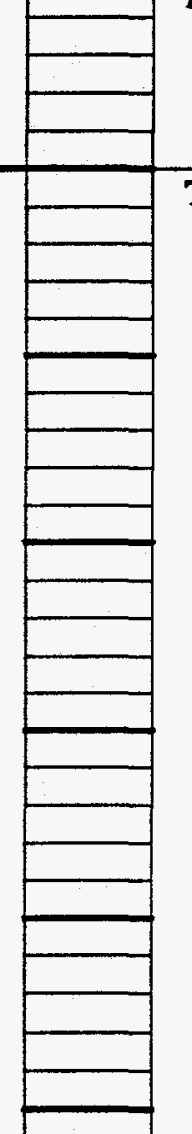

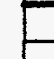
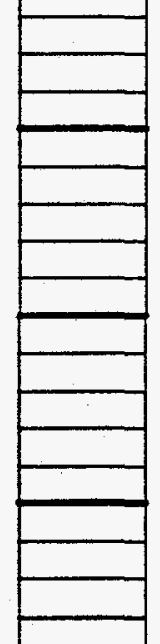

GROUNDWATER

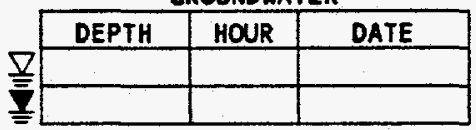


PROJECT GRAND JUNCTION PROCESS SITE

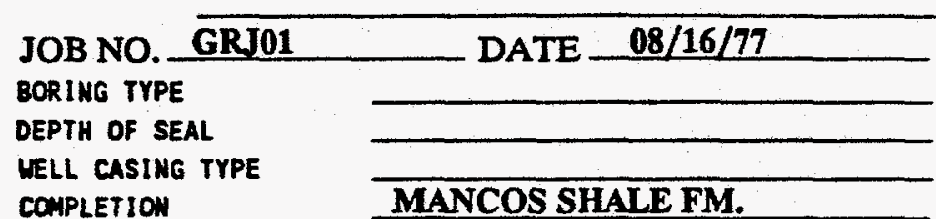

Page 1 of 2 LOG OF WELL BORING NO. 720

TOTAL DEPTH 54.5 feet

FIELD REP.

SURFACE ELEVATION 4734.00

LOCATION N 75490.00 E 49920.00

DATUM MSL

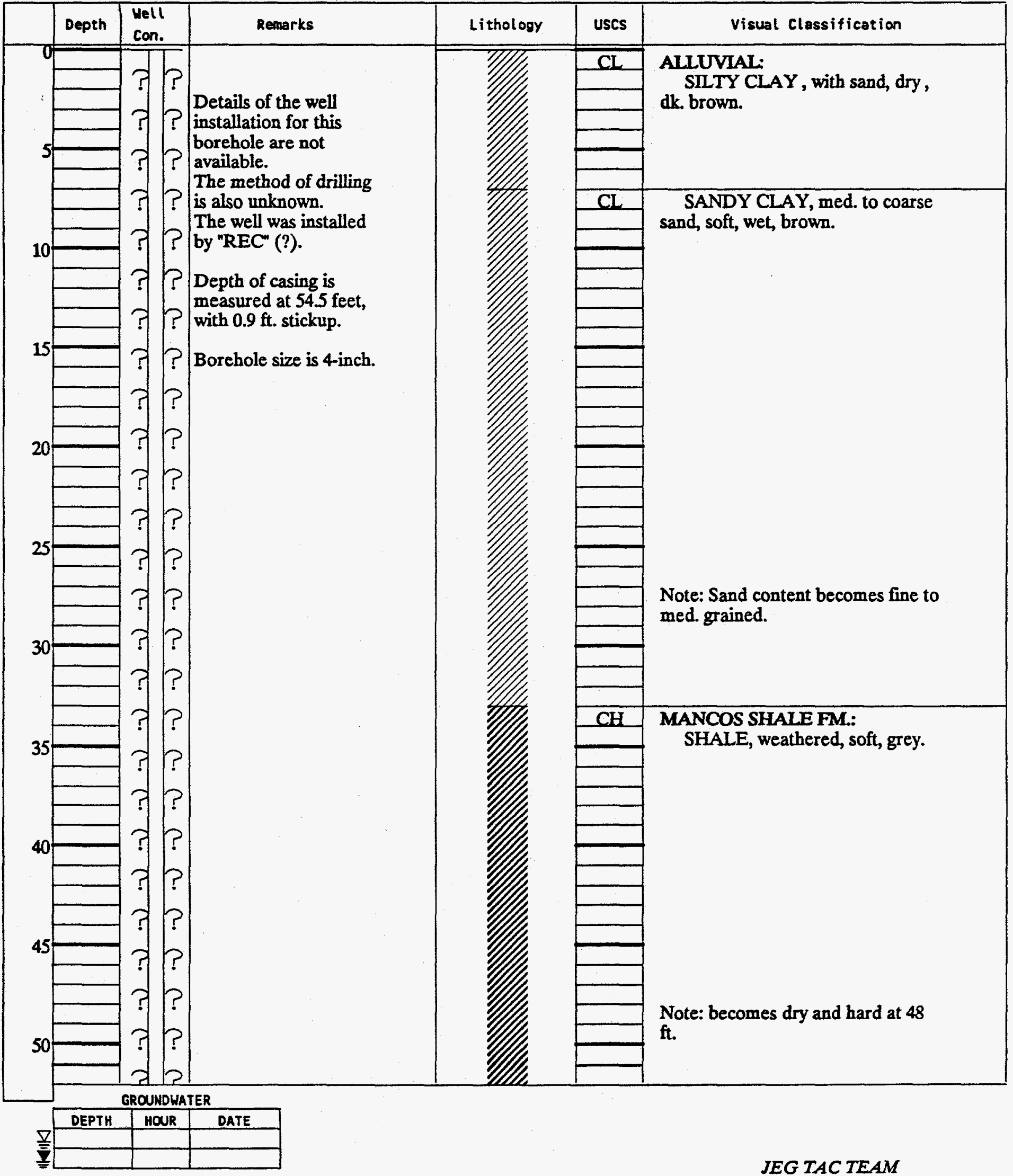


PROJECT GRAND JUNCTION PROCESS SITE

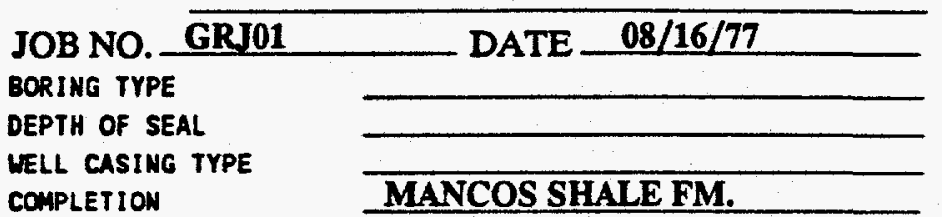

TOTAL DEPTH 54.5 feet

FIELD REP.

SURFACE ELEVATION $\quad 4734.00$

LOCATION N 75490.00 E 49920.00

COMPLETION

MANCOS SHALE FM. DATUM MSL

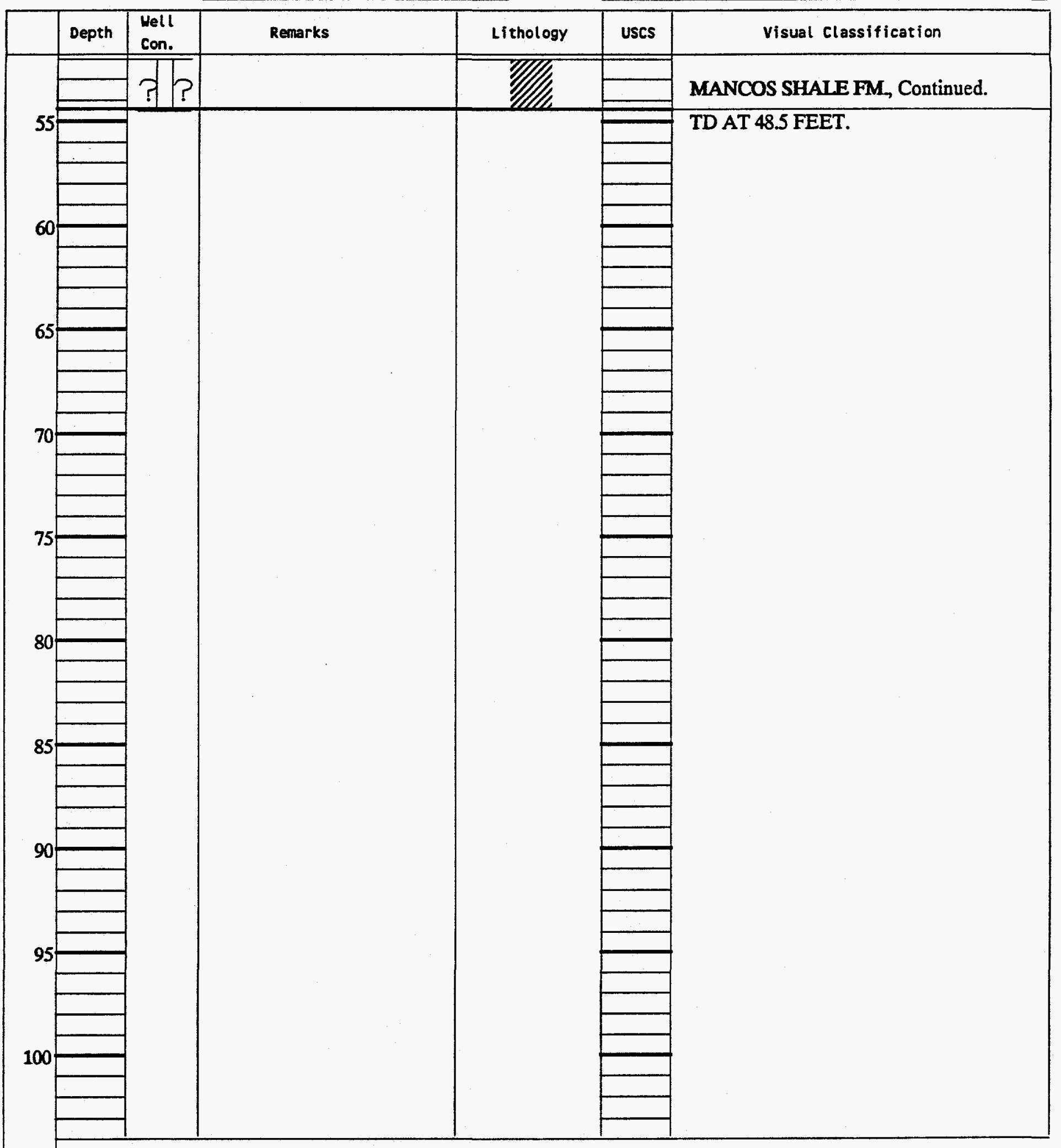

GROUNDWATER

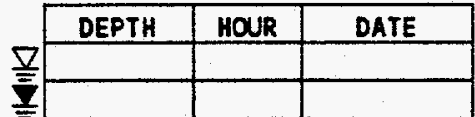


PROJECT GRAND JUNCTION PROCESS SITE

JOB NO. GRJ01

BORING TYPE

DEPTH OF SEAL

WELL CASING TYPE

COMPLETION
DATE $\quad 08 / 16 / 77$

MANCOS SHALE FM.
Page 1 of 1 LOG OF WELL BORING NO.

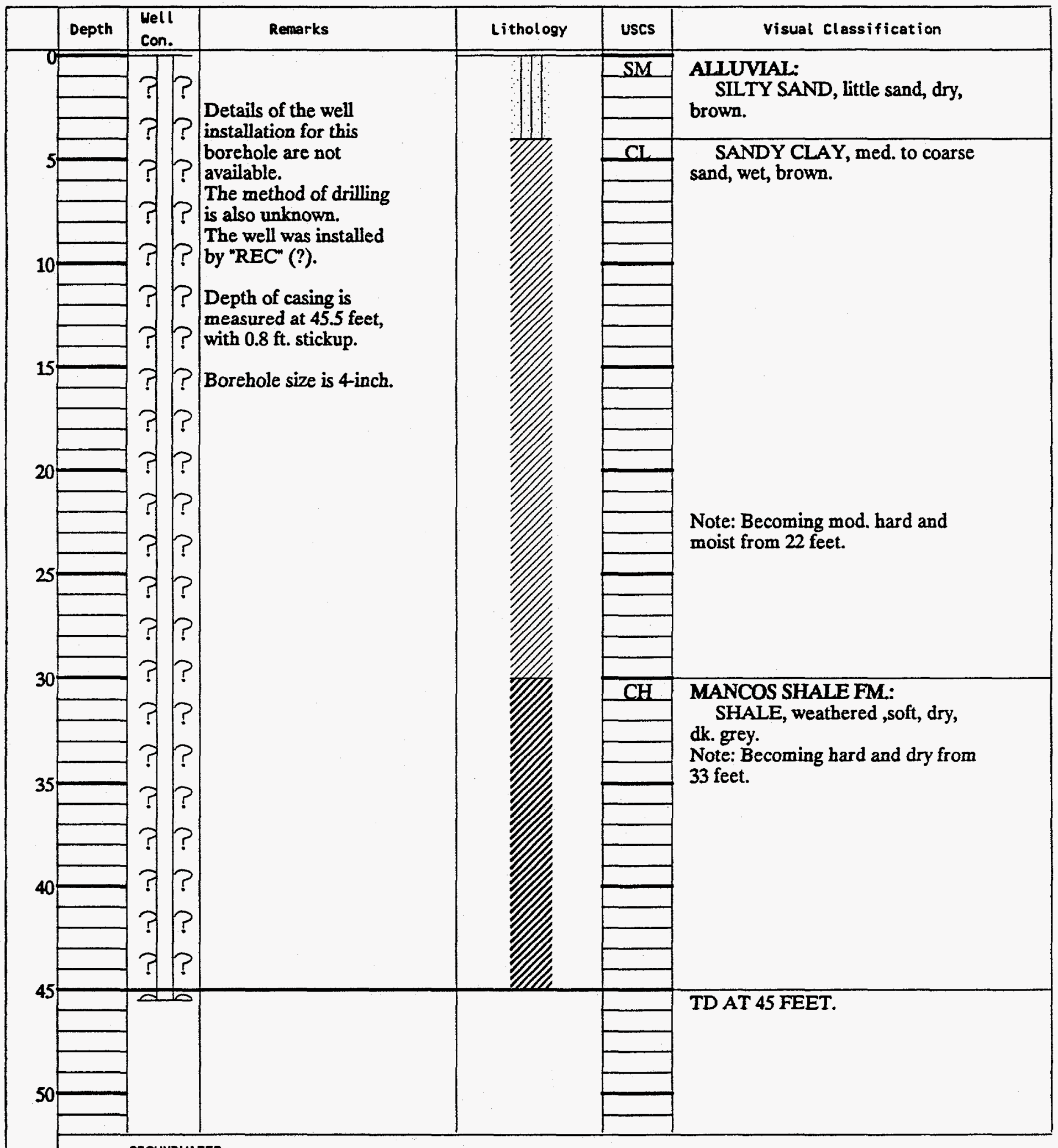

GROUNDWATER

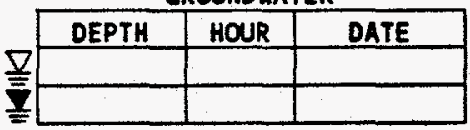


PROJECT GRAND JUNCTION PROCESS SITE

\begin{tabular}{|c|c|}
\hline JOB NO. GRJ01 & DATE $02 / 28 / 85$ \\
\hline BORING TYPE & CORE/ROTARY/WATER \\
\hline DEPTH OF SEAL & 126.50 \\
\hline MELL CASING TYPE & 2.0-IN.SCHED.40 PVC \\
\hline
\end{tabular}

Page 1 of 3 LOG OF WELL BORING NO.

TOTAL DEPTH 142.0 feet FIELD REP. W.WOOD

SURFACE ELEVATION $\quad \mathbf{4 5 6 4 . 7 0}$

LOCATION N 59894.50 E 31371.50

DATUM MSL

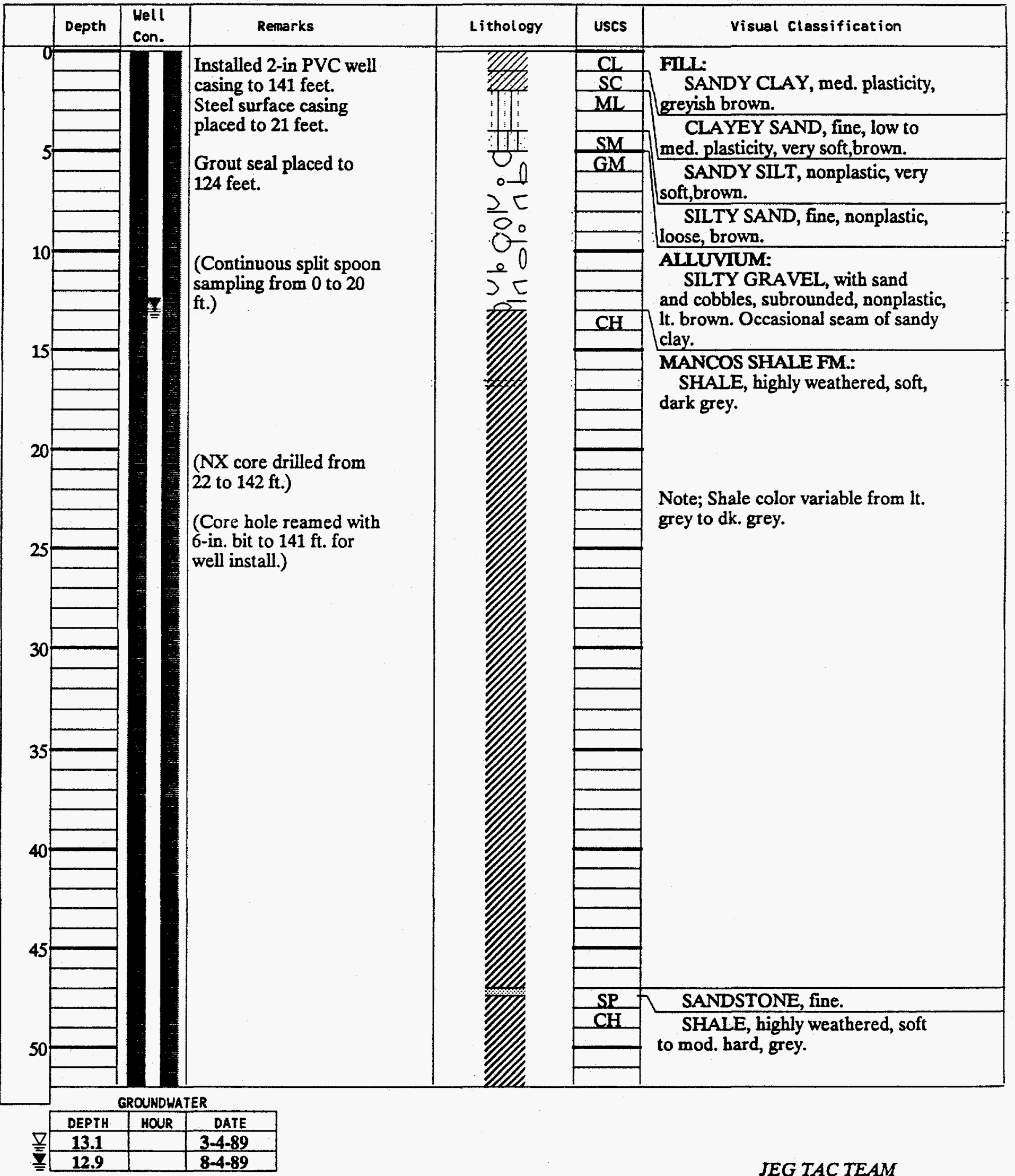


PROJECT GRAND JUNCTION PROCESS SITE

JOB NO. GRJ01

BORING TYPE

DEPTH OF SEAL

WELL CASING TYPE

COMPLETION
DATE 02/28/85 CORE/ROTARY/WATER 126.50

2.0-IN.SCHED.40 PVC DAKOTA SANDSTONE FM.
Page 2 of 3

LOG OF WELL BORING NO. 724

TOTAL DEPTH 142.0 feet

FIELO REP. W.WOOD

SURFACE ELEVATION 4564.70

LOCATION

DATUM
N 59894.50 E 31371.50

MSL

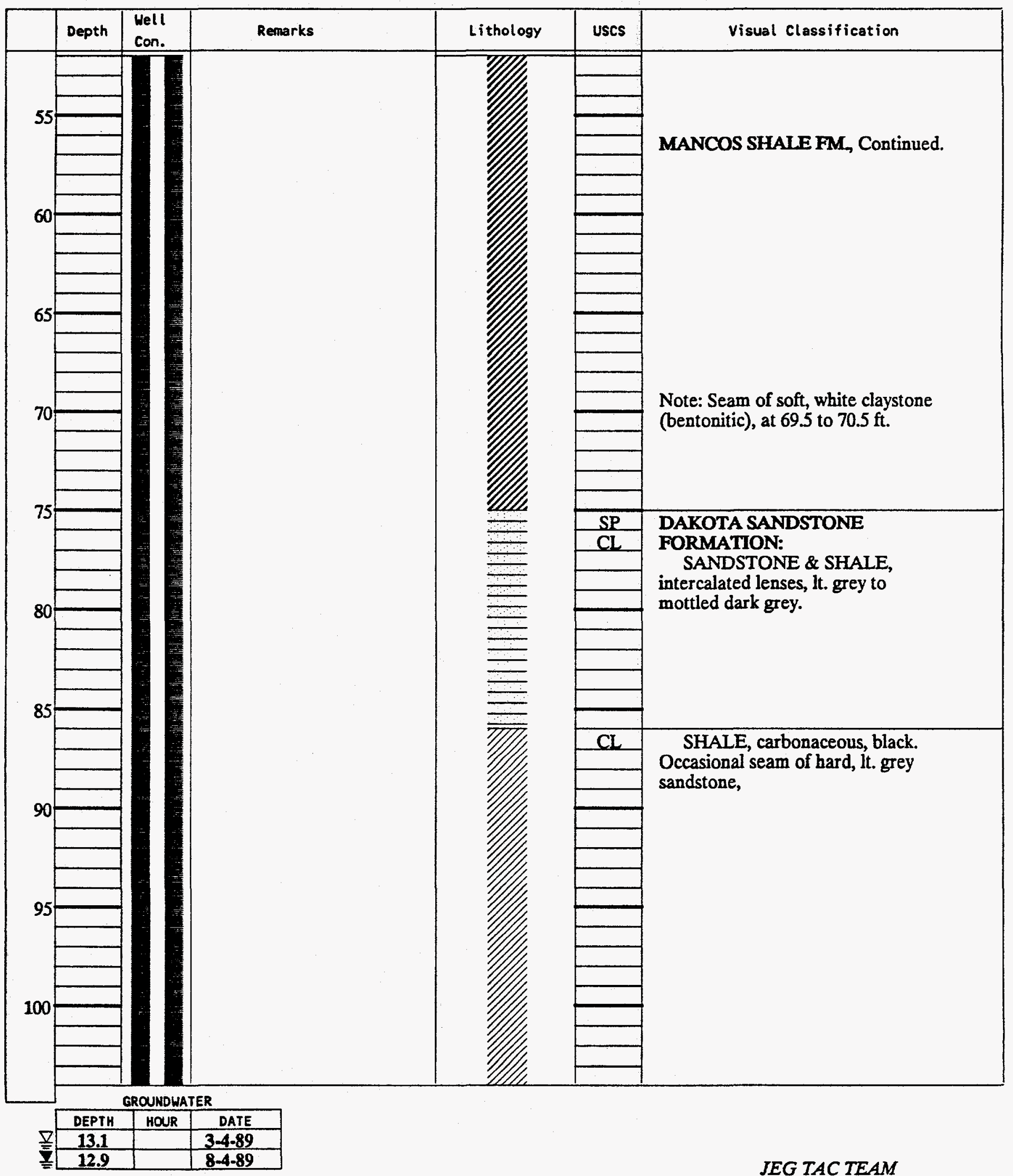


PROJECT GRAND JUNCTION PROCESS SITE

\begin{tabular}{ll} 
JOB NO. GRJ01 & \multicolumn{1}{c}{ DATE $02 / 28 / 85$} \\
BORING TYPE & CORE/ROTARY/WATER \\
DEPTH OF SEAL & 126.50 \\
MELL CASING TYPE & 2.0.IN.SCHED.40 PVC \\
\hline COMPLETION & DAKOTA SANDSTONE FM. \\
\hline
\end{tabular}

Page 3 of 3

LOG OF WELL BORING NO. 724

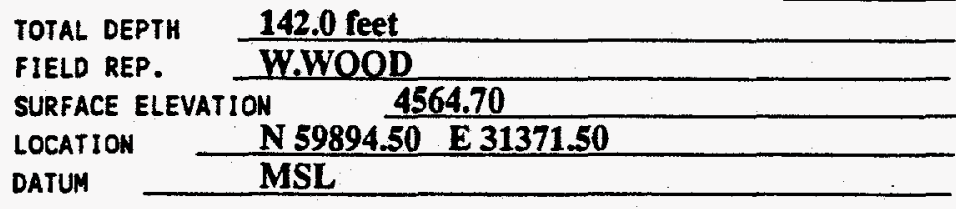

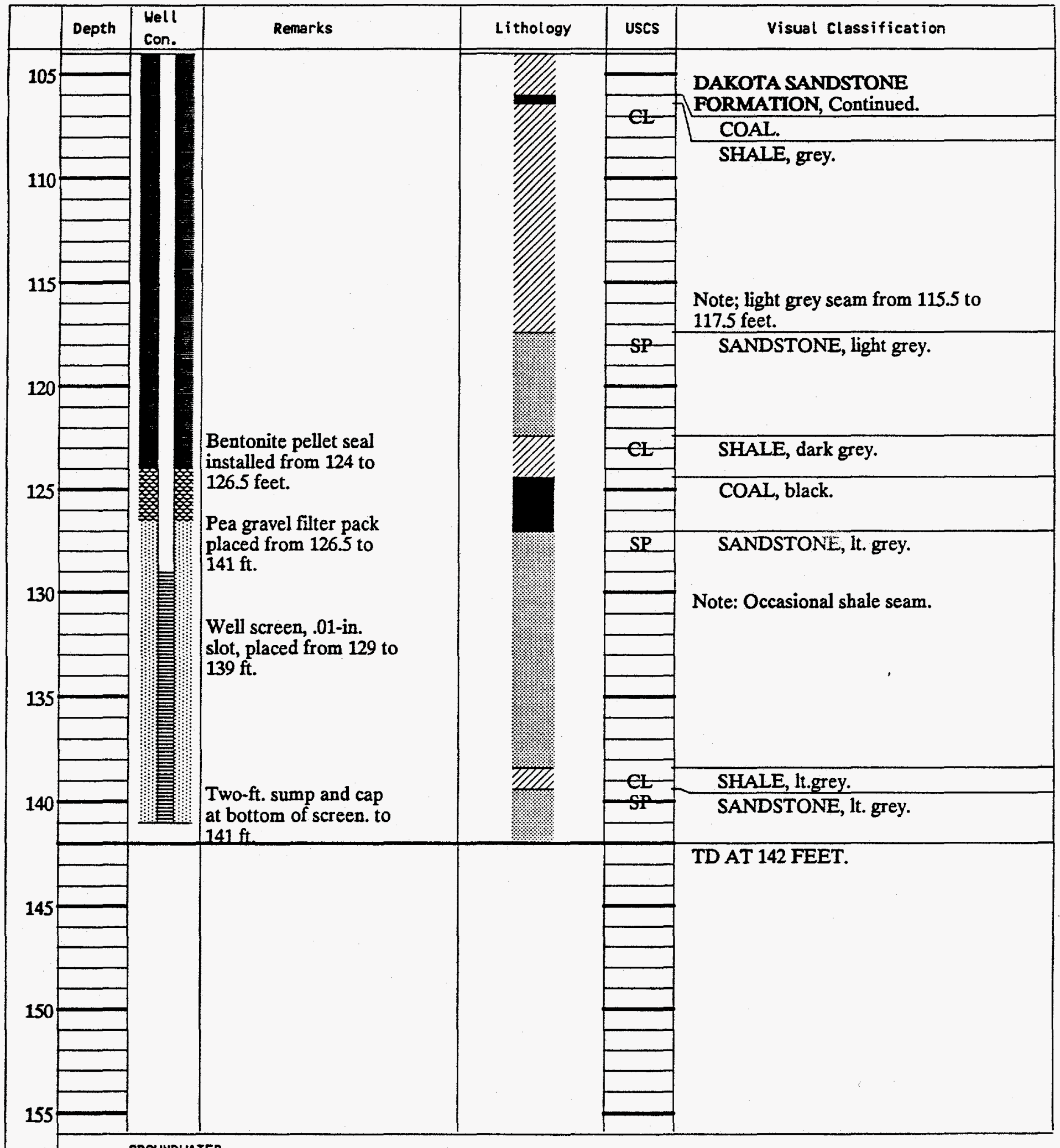

GROUNDWATER

\begin{tabular}{|c|c|c|}
\hline DEPTH & HOUR & DATE \\
\hline 13.1 & & $3-4-89$ \\
\hline \hline $\bar{z}$ & & $8-4.89$ \\
\hline
\end{tabular}


JOB NO. GRJ01

BORING TYPE

DEPTH OF SEAL

WELL CASING TYPE

COMPLETION

\begin{tabular}{l} 
DATE $\frac{02 / 26 / 85}{\text { CORE/ROTARY/AIR/H20 }}$ \\
36.00 \\
\hline D.0-IN.SCHED.40 PVC \\
DAKOTA SANDSTONE FM.
\end{tabular}

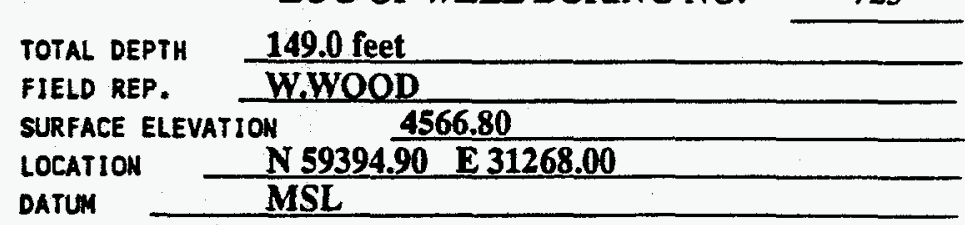

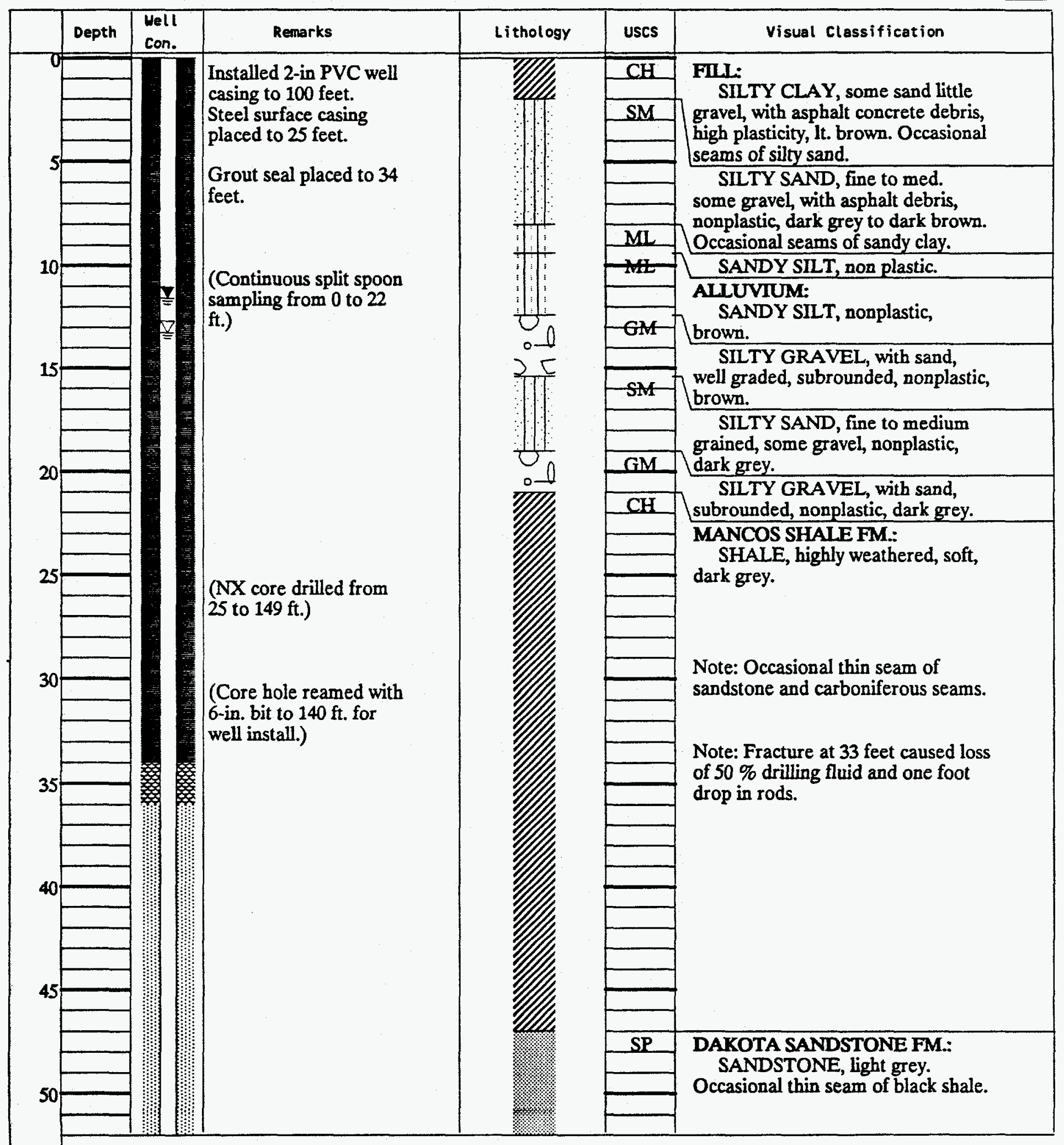

GROUNDHATER
\begin{tabular}{|c|c|c|}
\hline DEPTH & HOUR & DATE \\
\hline 13.3 & & $3-2-89$ \\
\hline 11.6 & & $8-5-89$ \\
\hline$\equiv$
\end{tabular}




\section{PROJECT GRAND JUNCTION PROCESS SITE}

\begin{tabular}{ll}
\hline JOB NO. GRJ01 & DATE $\frac{02 / 26 / 85}{\text { BORING TYPE }}$ \\
DEPTH OF SEAL & CORE/ROTARY/AIR/H20 \\
WELL CASING TYPE & 36.00 \\
COMPLETION & DA-IN.SCHED.40 PVC \\
\hline
\end{tabular}

Page 2 of 3 LOG OF WELL BORING NO.

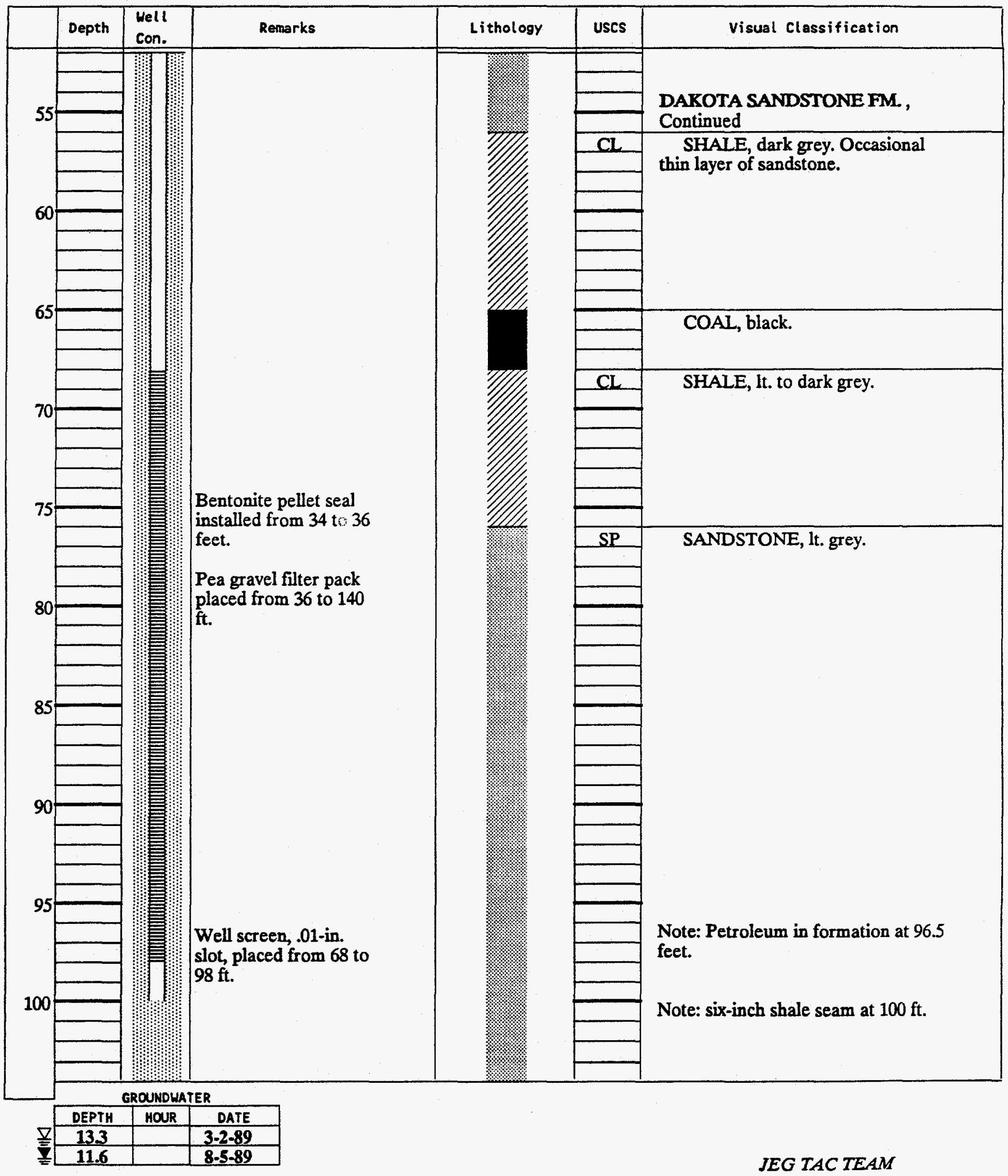

TOTAL DEPTH 149.0 feet

FIELO REP. W.WOOD

SURFACE ELEVATION 4566.80

LOCATION N 59394.90 E 31268.00

DATUM MSL 
PROJECT GRAND JUNCTION PROCESS SITE

\begin{tabular}{ll}
\hline JOB NO. GRJ01 & \multicolumn{1}{c}{ DATE $02 / 26 / 85$} \\
BORING TYPE & CORE/ROTARY/AIR/H20 \\
DEPTH OF SEAL & 36.00 \\
LELL CASING TYPE & 2.0-IN.SCHED.40 PVC \\
CONPLETION & DAKOTA SANDSTONE FM. \\
\hline
\end{tabular}

Page 3 of 3 LOG OF WELL BORING NO. 725

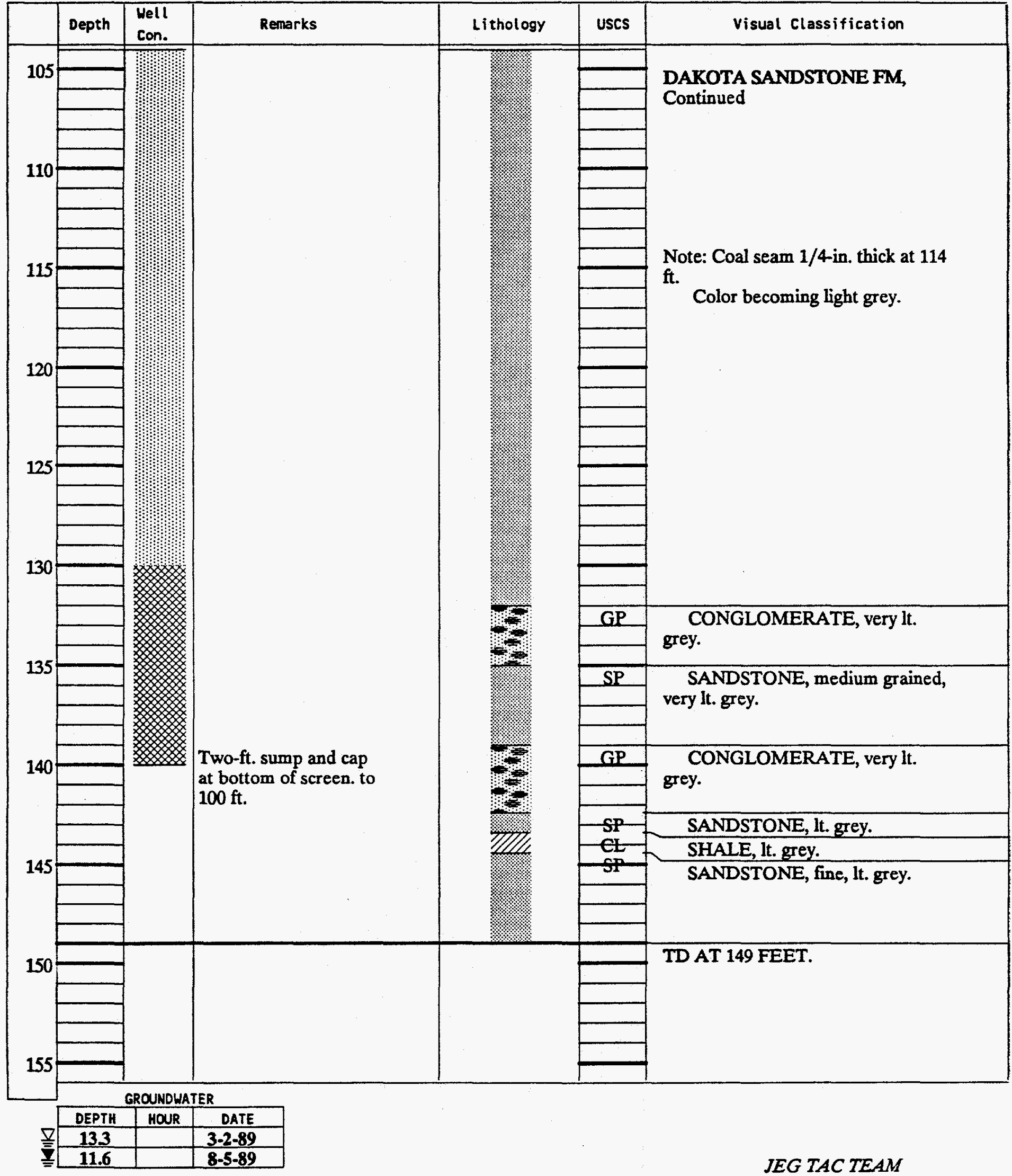


PROJECT GRAND JUNCTION PROCESS SITE

\begin{tabular}{ll} 
JOB NO. GRJ01 & \multicolumn{1}{c}{ DATE $\frac{03 / 10 / 85}{\text { BORING TYPE }}$} \\
DEPTH OF SEAL & ROTARY/WATER \\
UELL CASING TYPE & 73.00 \\
COMPLETION & DA-IN.SCHED.40 PVC \\
\hline
\end{tabular}

Page 1 of 3

LOG OF WELL BORING NO. 726

TOTAL DEPTH $\frac{140.0 \text { feet }}{\text { W.WOOD }}$
FIELD REP.
SURFACE ELEVATION 203566.80
$\begin{aligned} & \text { LOCATION } \\ & \text { DATUM }\end{aligned}$

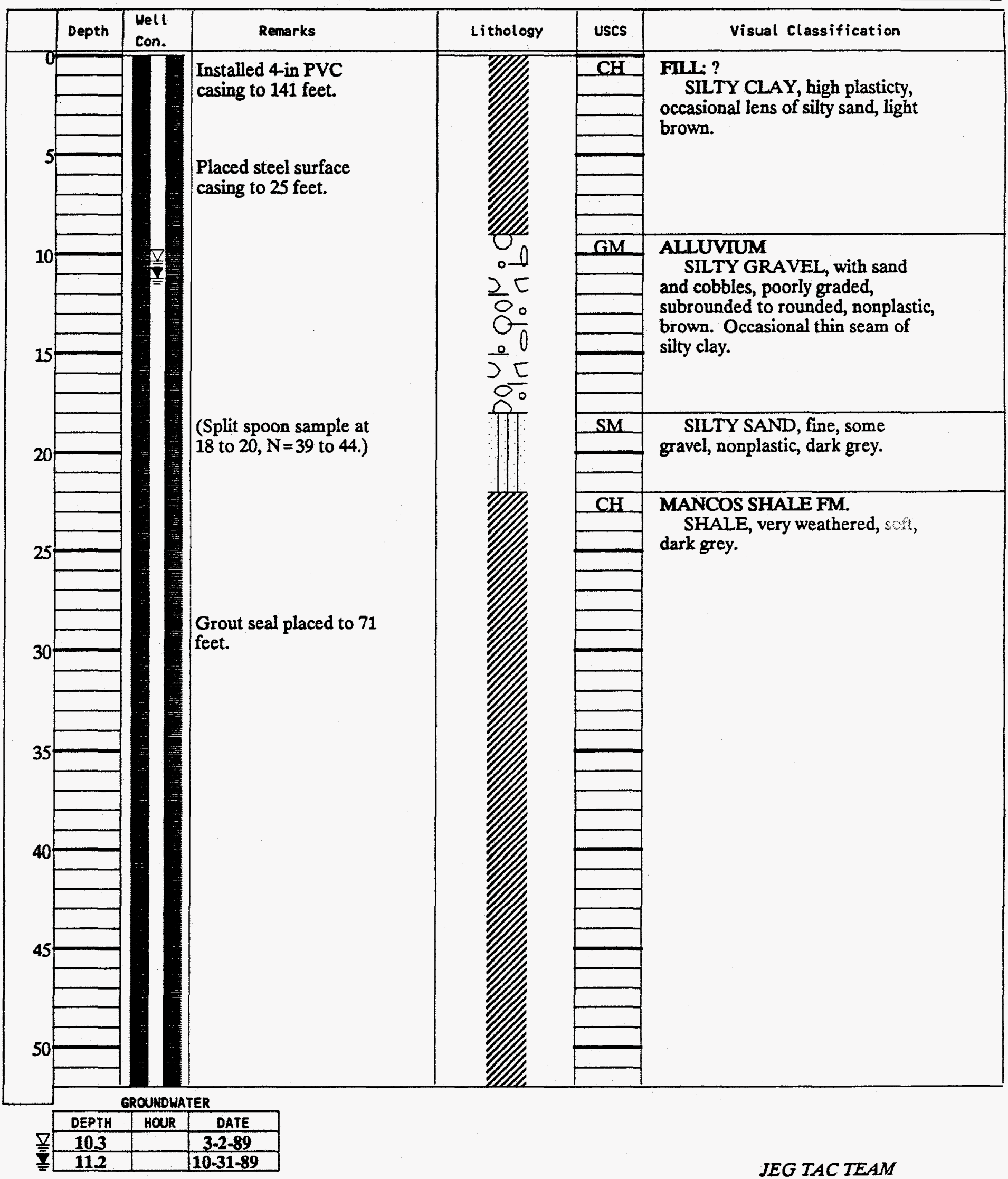


PROJECT GRAND JUNCTION PROCESS SITE

\begin{tabular}{ll} 
JOB NO. GRJ01 & \multicolumn{1}{c}{ DATE $03 / 10 / 85$} \\
BORING TYPE & ROTARY/WATER \\
OEPTH OF SEAL & 73.00 \\
WELL CASING TYPE & 4.0-IN.SCHED.40 PVC \\
COMPLETION & DAKOTA SANDSTONE FM. \\
\hline
\end{tabular}

Page 2 of 3

LOG OF WELL BORING NO. 726

TOTAL DEPTH 140.0 feet

FIELD REP. WWOOD

SURFACE ELEVATION 4566.80

LOCATION N 59393.00 E 31257.30

DATUM MSL

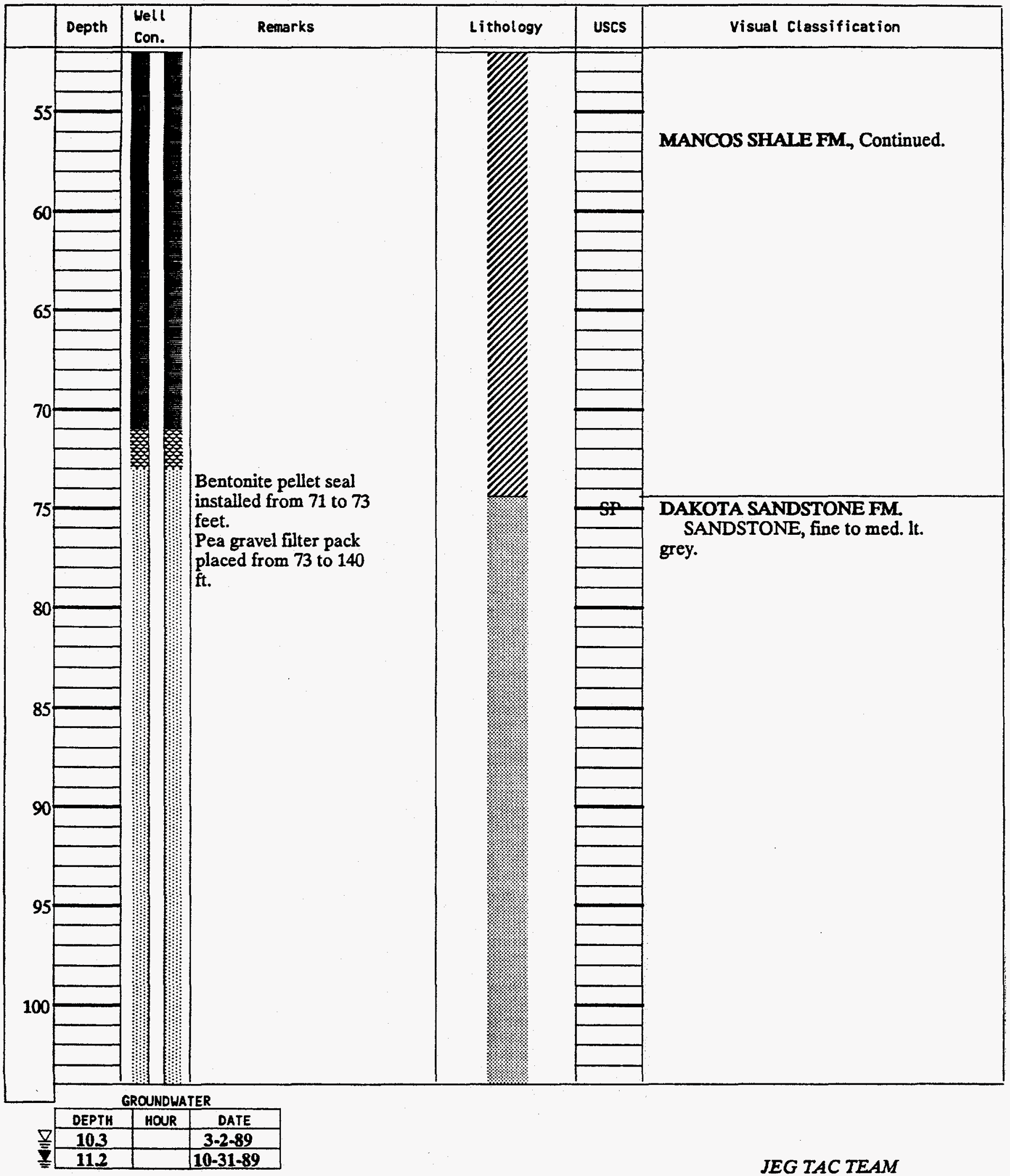




\begin{tabular}{ll} 
JOB NO. GRJ01 & \multicolumn{1}{c}{ DATE 03/10/85 } \\
BORING TYPE & ROTARY/WATER \\
DEPTH OF SEAL & 73.00 \\
WELL CASING TYPE & 4.0-IN.SCHED.40 PVC \\
COMPLETION & DAKOTA SANDSTONE FM. \\
\hline
\end{tabular}

TOTAL DEPTH 140.0 feet

FIELD REP. W.WOOD

SURFACE ELEVATION $\quad 4566.80$

LOCATION N 59393.00 E 3125730

DATUM MSL

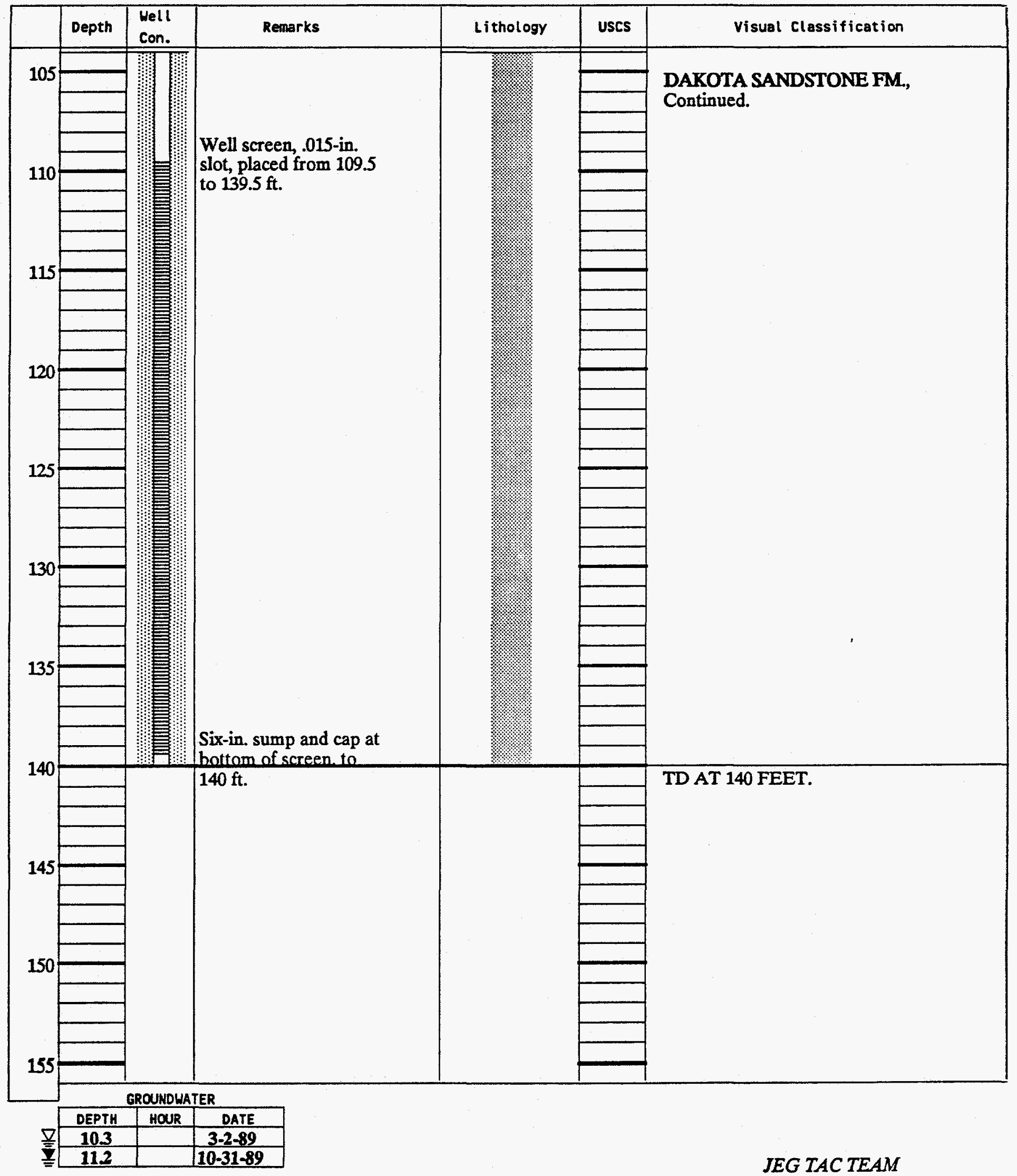


Page 1 of 2

\begin{tabular}{ll} 
JOB NO. GRJ01 & \multicolumn{1}{c}{ DATE 03/03/85 } \\
BORING TYPE & ROTARY W/AIR/WATER \\
DEPTH OF SEAL & 41.20 \\
UELL CASING TYPE & 2.0-IN.SCHED.40 PVC \\
COMPLETION & MANCOS SHALE FM. \\
\hline
\end{tabular}

TOTAL DEPTH $\mathbf{5 5 2} 2$ feet

FIELD REP. W.WOOD

SURFACE ELEVATION $\quad \mathbf{5 6 6 . 4 0}$

LOCATION N 59380.30 E 31265.30

DATUM MSL

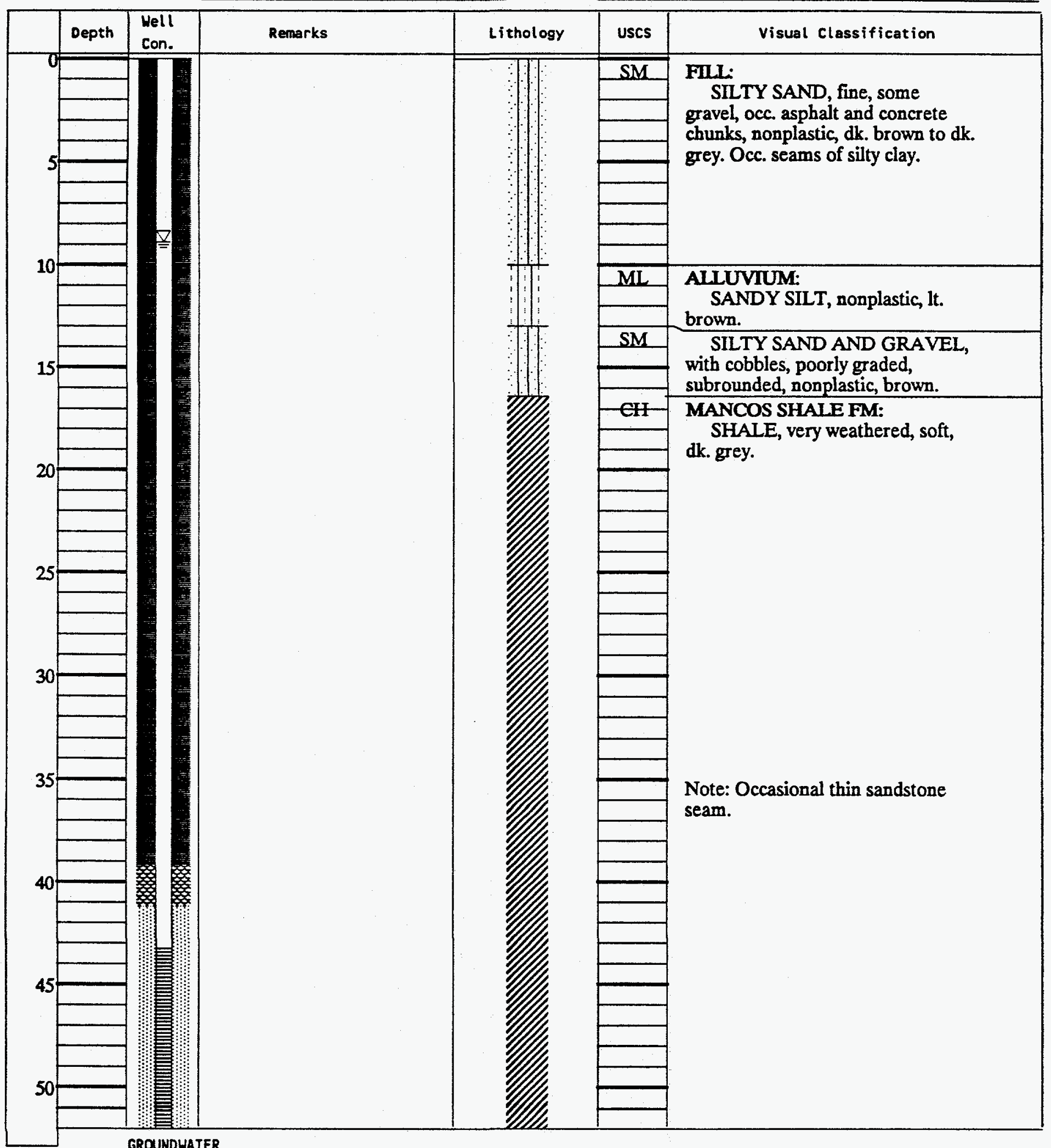

GROUNDWATER

\begin{tabular}{|c|c|c|}
\hline DEPTH & HOUR & DATE \\
\hline 8.9 & $12: 35$ & $\mathbf{7 . 2 4 - 8 6}$ \\
\hline & & \\
\hline
\end{tabular}


PROJECT GRAND JUNCTION PROCESS SITE

JOB NO. GRJ01

BORING TYPE

DEPTH OF SEAL

WELL CASING TYPE

COMPLETION
DATE 03/03/85

ROTARY W/AIR/WATER

41.20

2.0-IN.SCHED.40 PVC

MANCOS SHALE FM.

Page 2 of 2 LOG OF WELL BORING NO.

TOTAL DEPTH 55.2 feet

FIELD REP. W.WOOD

SURFACE ELEVATION 4566.40

LOCATION N 59380.30 E 31265.30

DATUM MSL

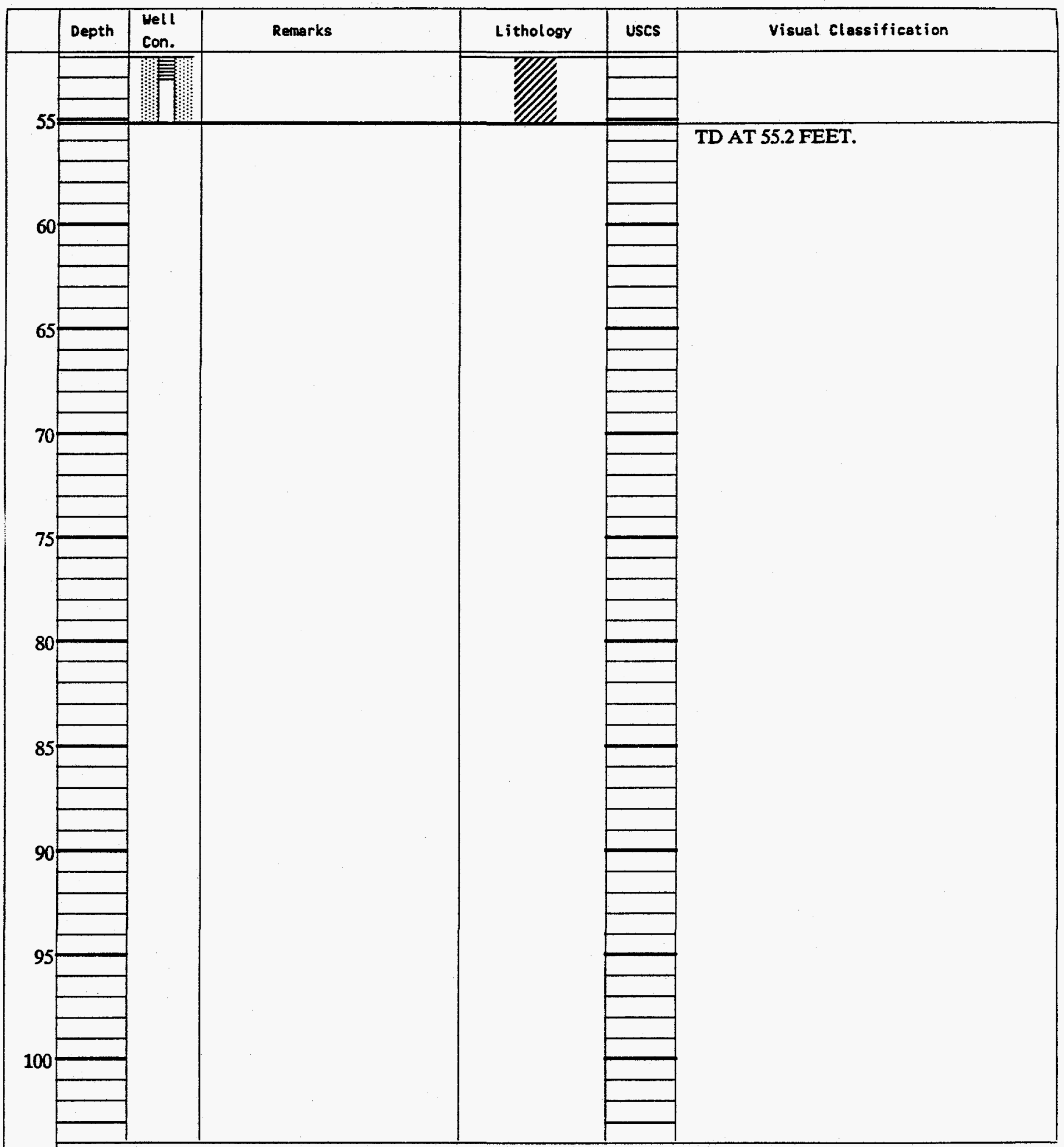

GROUNDHATER

\begin{tabular}{|c|c|c|}
\hline DEPTH & HOUR & DATE \\
\hline 8.9 & 12.35 & $7-24-86$ \\
\hline & & \\
\hline & \\
\hline
\end{tabular}


PROJECT GRAND JUNCTION PROCESS SITE

\begin{tabular}{ll}
\hline JOB NO. GRJ01 & \multicolumn{1}{c}{ DATE $\frac{02 / 25 / 85}{\text { GORING TYPE }}$} \\
DEPTH OF SEAL & ROTARY W/REVERT \\
WELL CASING TYPE & 8.00 \\
COMPLETION & M.0-IN.SCHED.40 PVC \\
\hline
\end{tabular}

Page 1 of 1 LOG OF WELL BORING NO. 728

TOTAL DEPTH 17.0 feet

FIELD REP. MCKENZIE

SURFACE ELEVATION 4565.00

LOCATION N 59518.50 E 31296.10

DATUM MSL

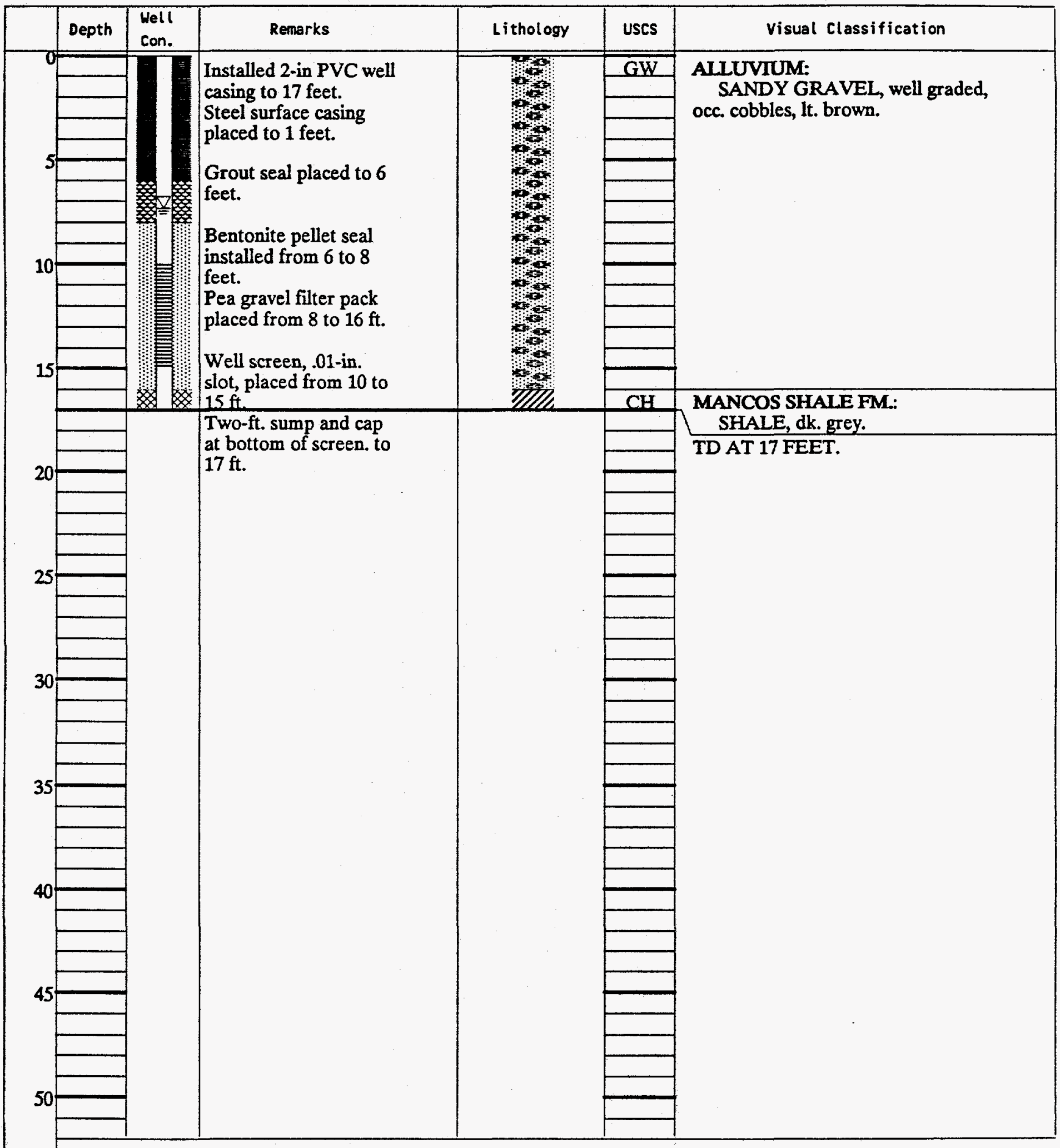

GROUNDHATER

\begin{tabular}{|c|c|c|}
\hline DEPTH & HOUR & DATE \\
\hline 73 & $11: 10$ & $\mathbf{7 - 2 4 - 8 6}$ \\
\hline & & \\
\hline
\end{tabular}


PROJECT GRAND JUNCTION PROCESS SITE

Page 1 of 2

\begin{tabular}{ll}
\hline JOB NO. GRJ01 & \multicolumn{1}{c}{ DATE $\frac{03 / 02 / 85}{\text { BORING TYPE }}$} \\
$\begin{array}{ll}\text { DEPTH OF SEAL } \\
\text { WELL CASING TYPE } \\
\text { COMPLETION }\end{array}$ & CORE/ROTARY/WATER \\
\hline & 2.0-IN.SCHED.40 PVC \\
\hline
\end{tabular}

TOTAL DEPTH 65.0 feet

FIELD REP. W.WOOD

SURFACE ELEVATION 4565.30

LOCATION N 59738.70 E 32572.30

DATUM MSL

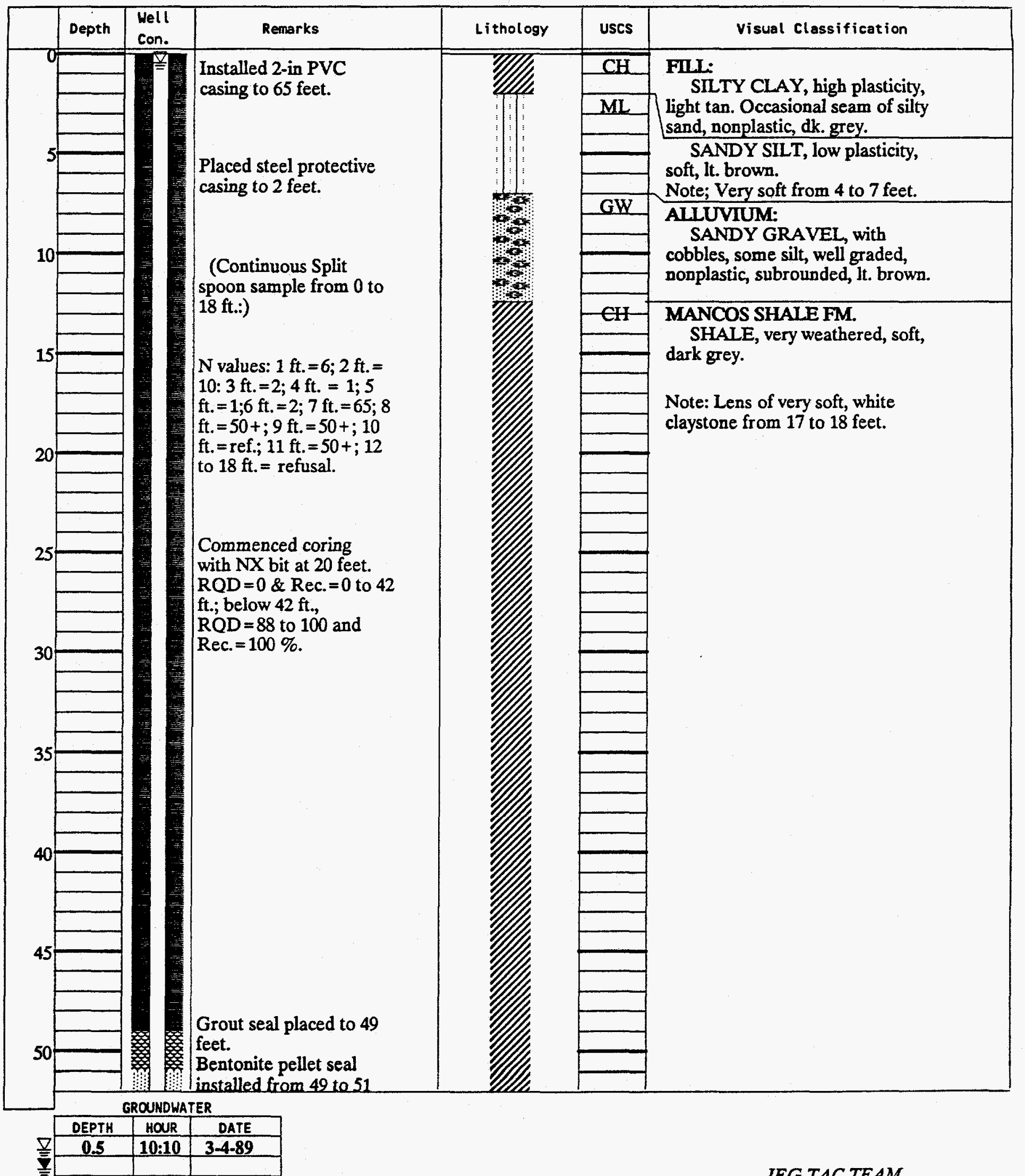


PROJECT GRAND JUNCTION PROCESS SITE

\begin{tabular}{ll} 
JOB NO. GRJ01 & \multicolumn{1}{c}{ DATE $03 / 02 / 85$} \\
BORING TYPE & CORE/ROTARY/WATER \\
DEPTH OF SEAL & 51.00 \\
UELL CASING TYPE & 2.0-IN.SCHED.40 PVC \\
COMPLETION & MANCOS SHALE FM. \\
\hline
\end{tabular}

Page 2 of 2

LOG OF WELL BORING NO. 729

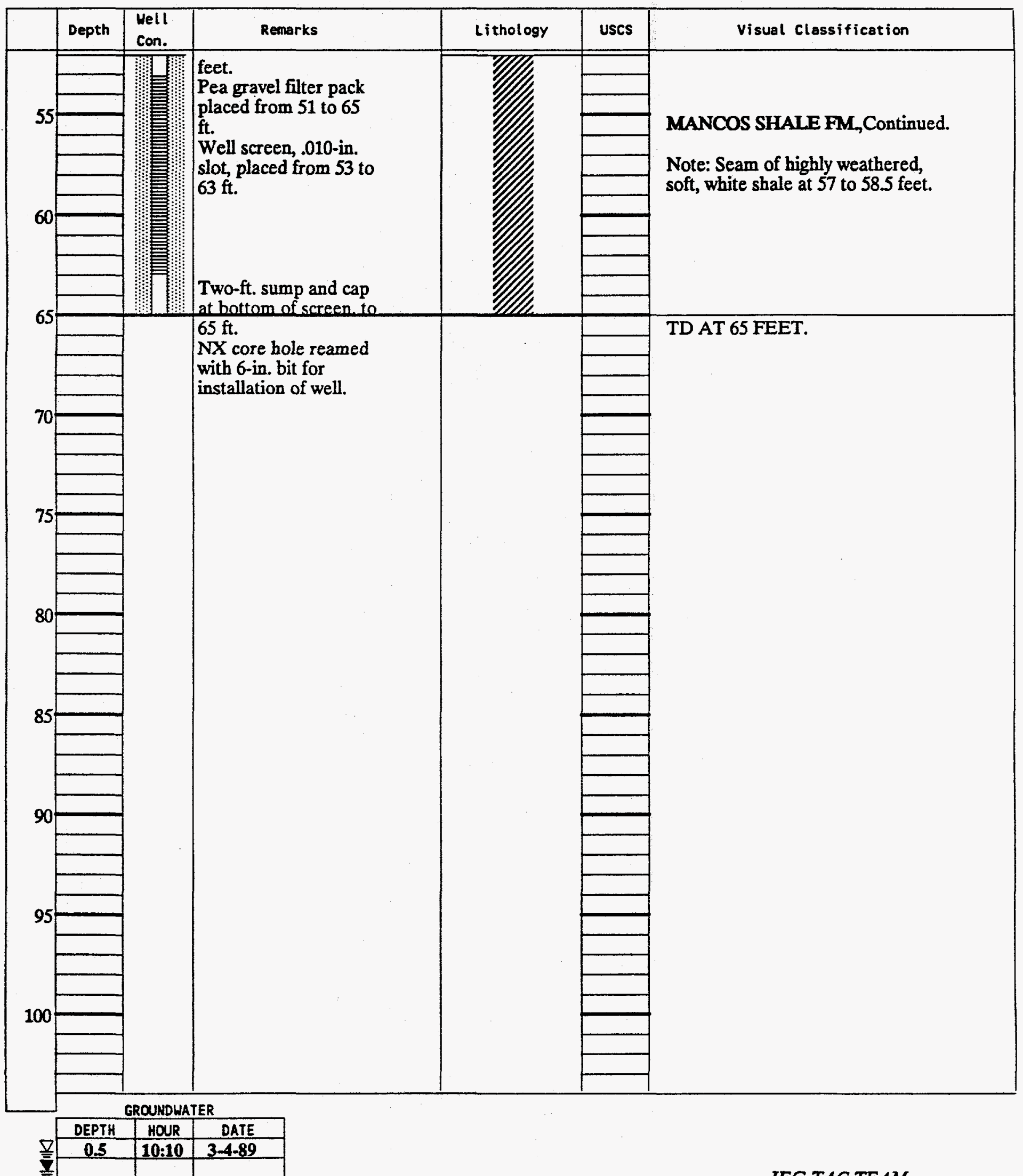




$\begin{array}{ll}\text { JOB NO. GRJ01 } & \text { DATE 03/08/85 } \\ \text { BORING TYPE } & \text { CORE/ROTARY/ WATER } \\ \text { DEPTH OF SEAL } & 21.50 \\ \text { MELL CASING TYPE } & 2.0 \text {-IN.SCHED.40 PVC } \\ \text { COMPLETION } & \text { MANCOS SHALE FM. }\end{array}$

TOTAL DEPTH 46.0 feet

FIELD REP. W.WOOD

SURFACE ELEVATION 4559.70

LOCATION N 60671.60 E 29820.30

DATUM MSL

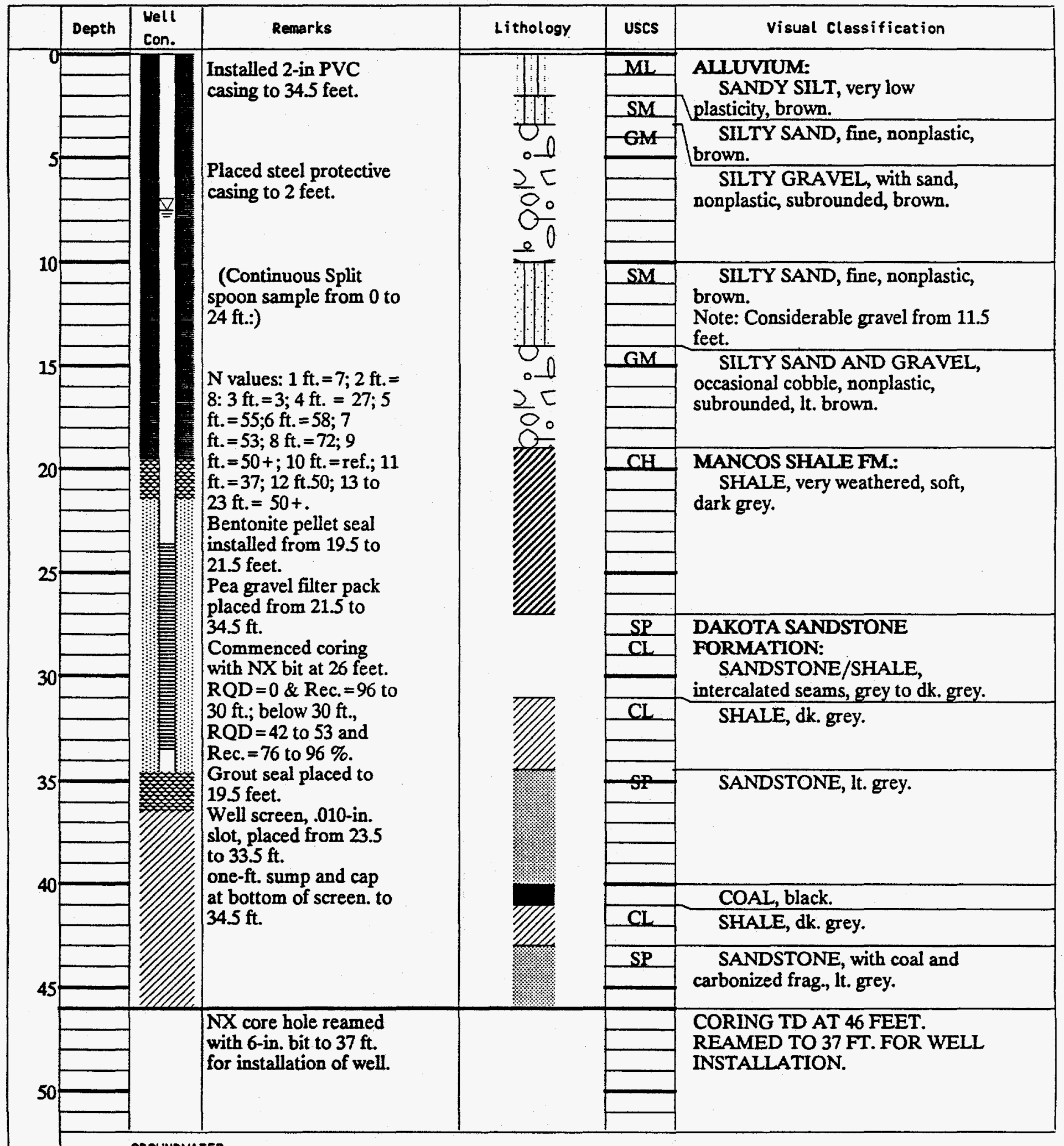

\begin{tabular}{|c|c|c|}
\hline DEPTH & HOUR & DATE \\
\hline 7.5 & 09.30 & $7-23-89$ \\
\hline & & \\
\hline
\end{tabular}


PROJECT GRAND JUNCTION PROCESS SITE

\begin{tabular}{ll} 
JOB NO. GRJ01 & \multicolumn{1}{c}{ DATE $\frac{02 / 25 / 85}{\text { BORING TYPE }}$} \\
$\begin{array}{l}\text { DEPTH OF SEAL } \\
\text { WELL CASING TYPE } \\
\text { COMPLETION }\end{array}$ & 12.00 /ROTARY/ REVERT \\
\hline & 2.0.IN.SCHED.40 PVC \\
\hline
\end{tabular}

Page 1 of 1 LOG OF WELL BORING NO.

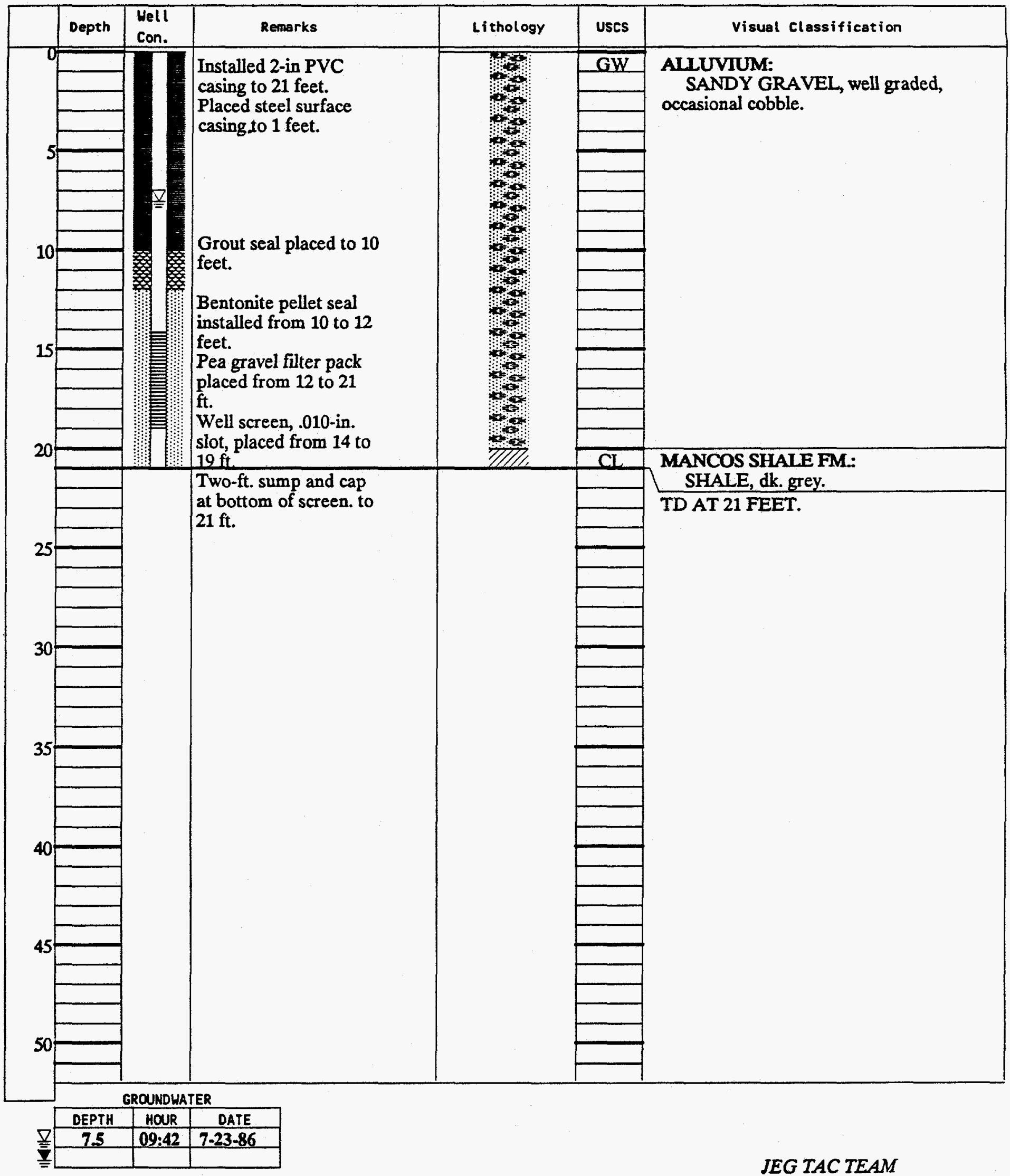




\begin{tabular}{ll} 
JOB NO. GRJ01 & DATE 02/26/85 \\
BORING TYPE & CORE W/ROTARY REAM \\
DEPTH OF SEAL & 11.00 \\
MELL CASING TYPE & 2.0-IN.SCHED.40 PVC \\
COHPLETION & ALLUVIUM. \\
\hline
\end{tabular}

$\begin{array}{ll}\text { TOTAL DEPTH } & 22.0 \text { feet } \\ \text { FIELD REP. } & \text { P.MCKENZIE }\end{array}$

SURFACE ELEVATION $\quad 4556.40$

LOCATION N 60997.40 E 28704.70

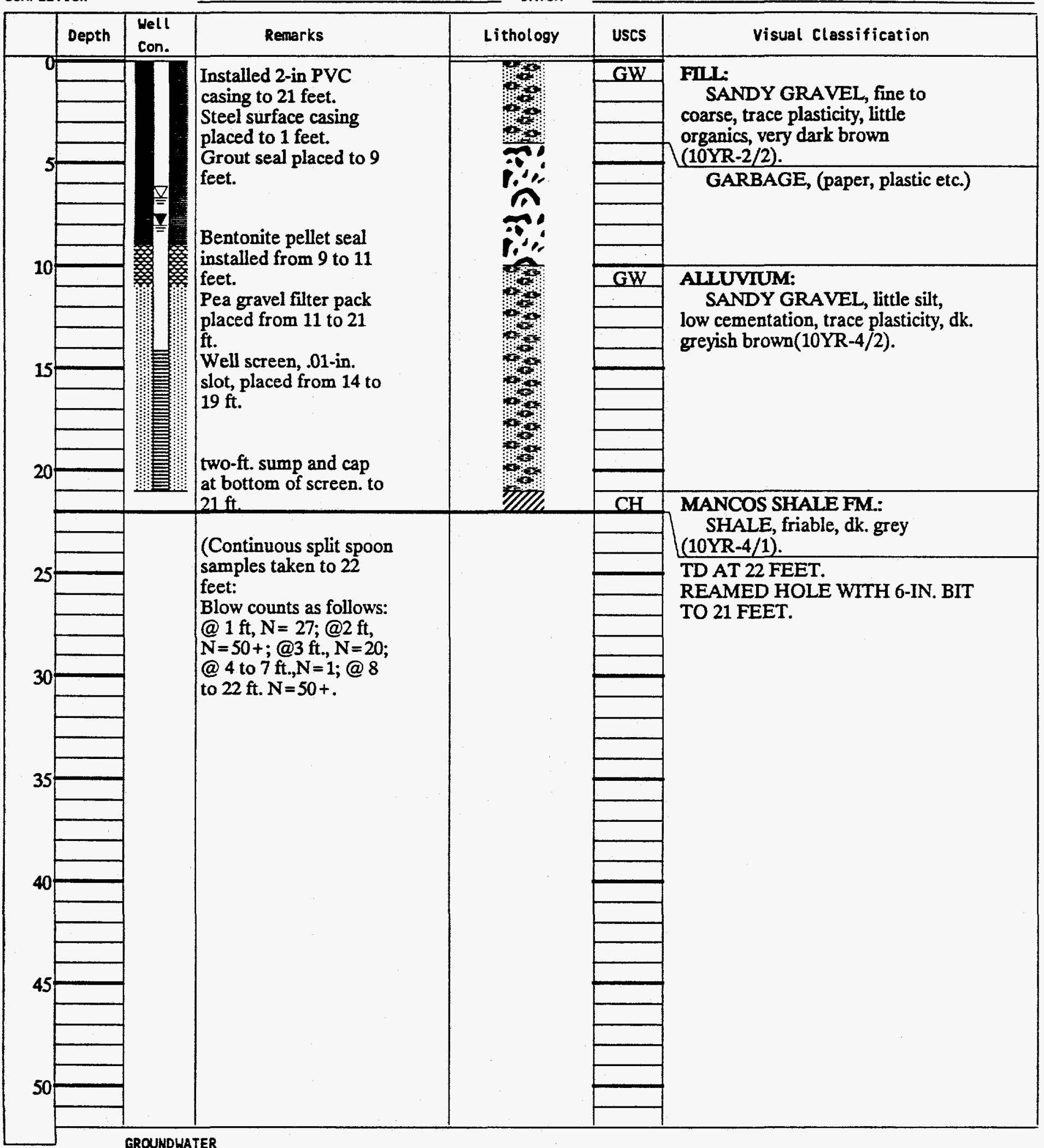

GROUNDWATER

\begin{tabular}{|c|c|c|}
\hline DEPTH & HOUR & DATE \\
\hline 6.7 & $10: 06$ & $7-23-86$ \\
\hline $\mathbf{8 . 1}$ & $08: 20$ & $\mathbf{2 - 2 8 - 8 9}$ \\
\hline
\end{tabular}




\begin{tabular}{ll}
\hline JOB NO, GRJ01 & \multicolumn{1}{c}{ DATE 02/28/85 } \\
BORING TYPE & CORE/ROTARY REAM \\
DEPTH OF SEAL & 24.00 \\
LELL CASING TYPE & 2.0-IN.SCHED.40 PVC \\
\cline { 2 - 2 } COMPLETION & MANCOS SHALE FM. \\
\hline
\end{tabular}

TOTAL DEPTH $\frac{50.0 \text { feet }}{\text { W.WOOD }}$
FIELD REP.
SURFACE ELEVATION
LOCATION $\frac{\text { N } 60211.60 \text { E } 31261.70}{\text { MSL }}$
DATUM

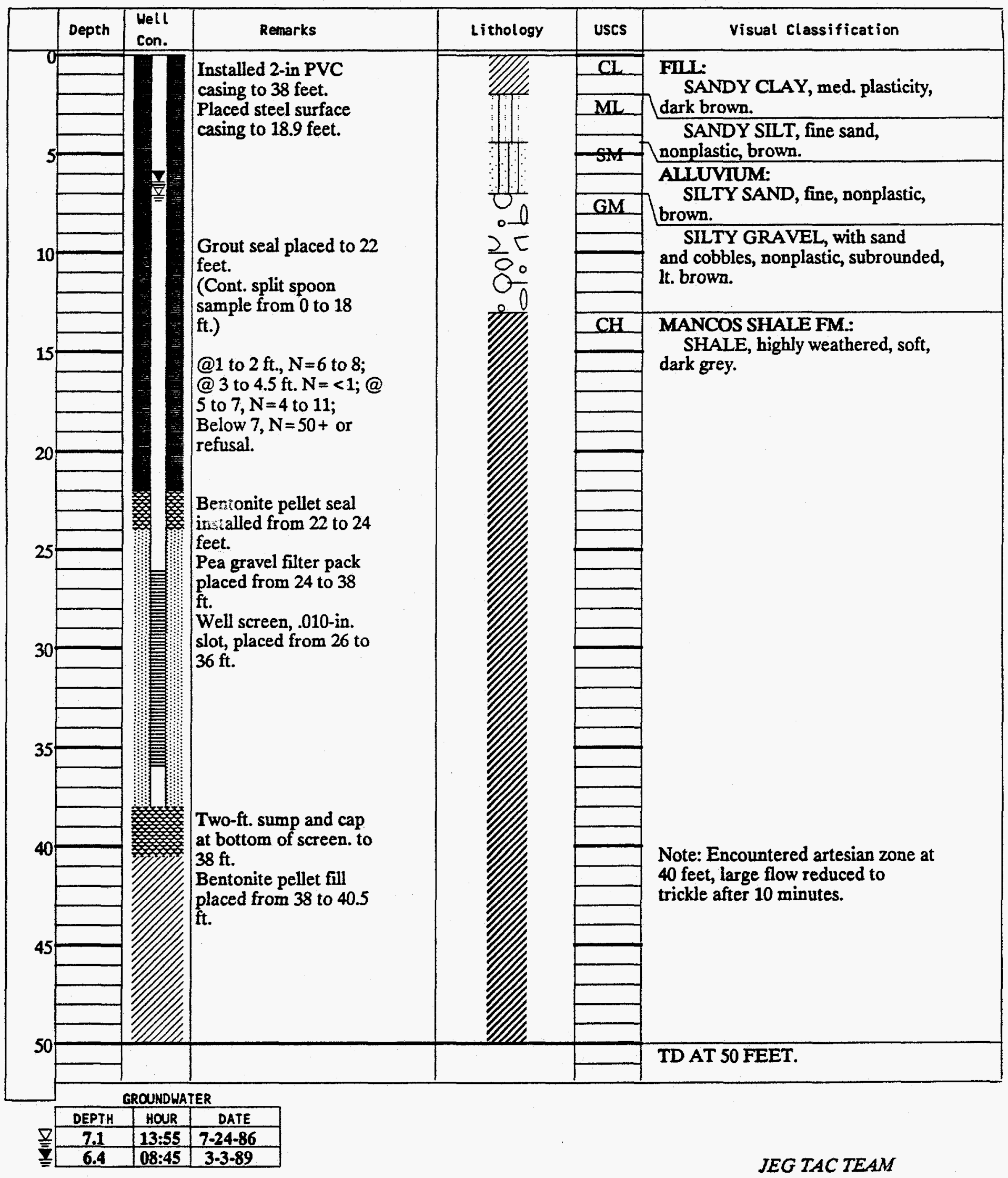


PROJECT GRAND JUNCTION PROCESS SITE

\begin{tabular}{ll}
\hline JOB NO. GRJ01 & \multicolumn{1}{c}{ DATE $02 / 24 / 85$} \\
BORING TYPE & ROTARYW/REVERT MUD \\
OEPTH OF SEAL & 6.00 \\
MELL CASING TYPE & 2.0-IN.SCHED.40 PVC \\
\hline COMPLETION & ALLUVIUM \\
\hline
\end{tabular}

Page 1 of 1 LOG OF WELL BORING NO.

TOTAL DEPTH 15.5 feet

FIELD REP. P.MCKENZIE

SURFACE ELEVATION $\mathbf{4 5 6 4 . 7 0}$

LOCATION N60197.90 E 31270.50

DATUM MSL

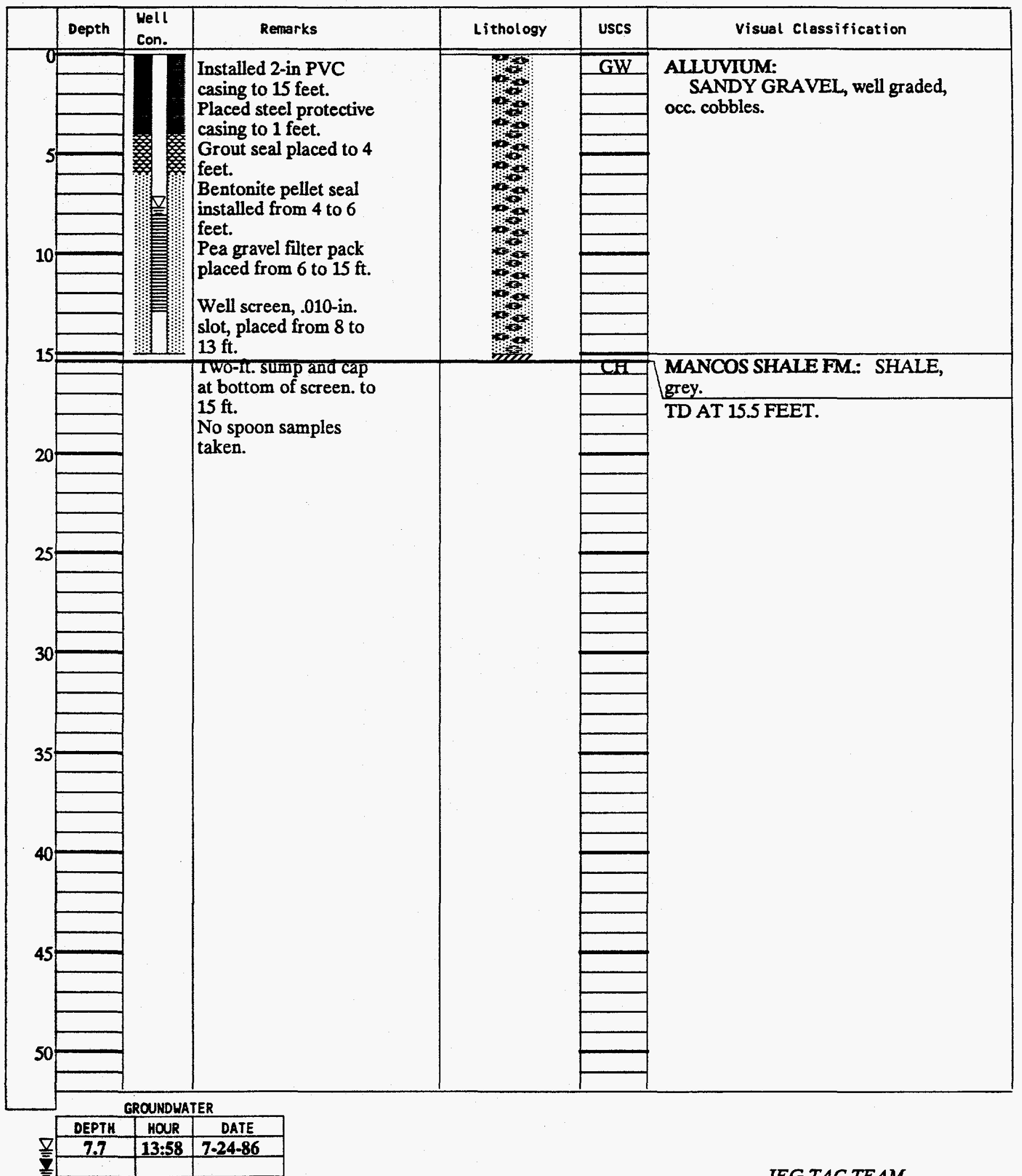




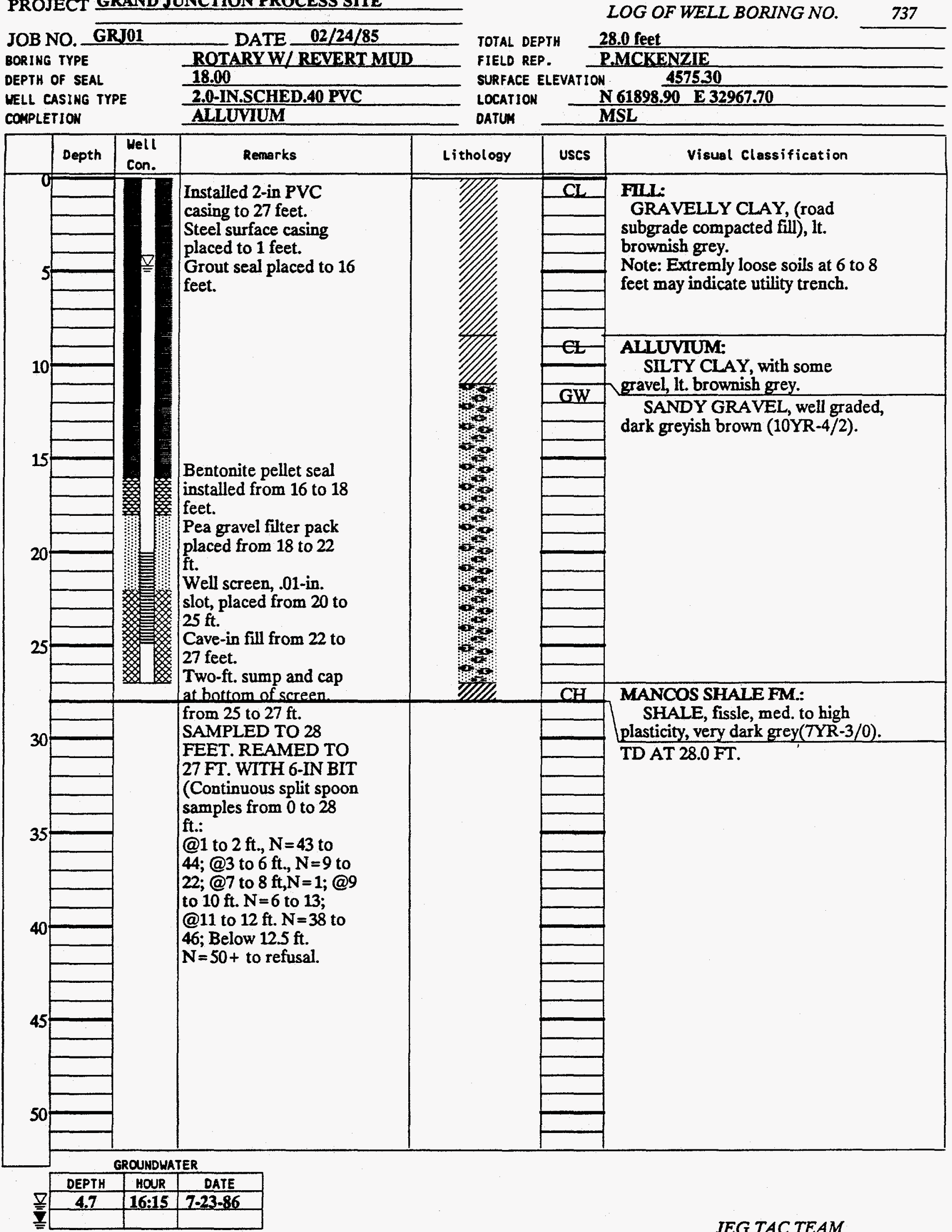




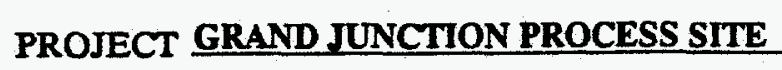

Page 1 of 1

$\begin{array}{ll}\text { JOB NO. GRJ01 } & \text { DATE } \frac{02 / 23 / 85}{1} \\ \text { BORING TYPE } & \text { ROTARYW/REVERT } \\ \text { DEPTH OF SEAL } & 9.00 \\ \text { UELL CASING TYPE } & \text { 2.0-IN.SCHED.40 PVC } \\ \text { CONPLETION } & \text { ALLUVIUM }\end{array}$

TOTAL DEPTH 18.0 feet

FIELD REP. P.MCKENZIE

SURFACE ELEVATION 4561.00

LOCATION N 60039.10 E 30049.40

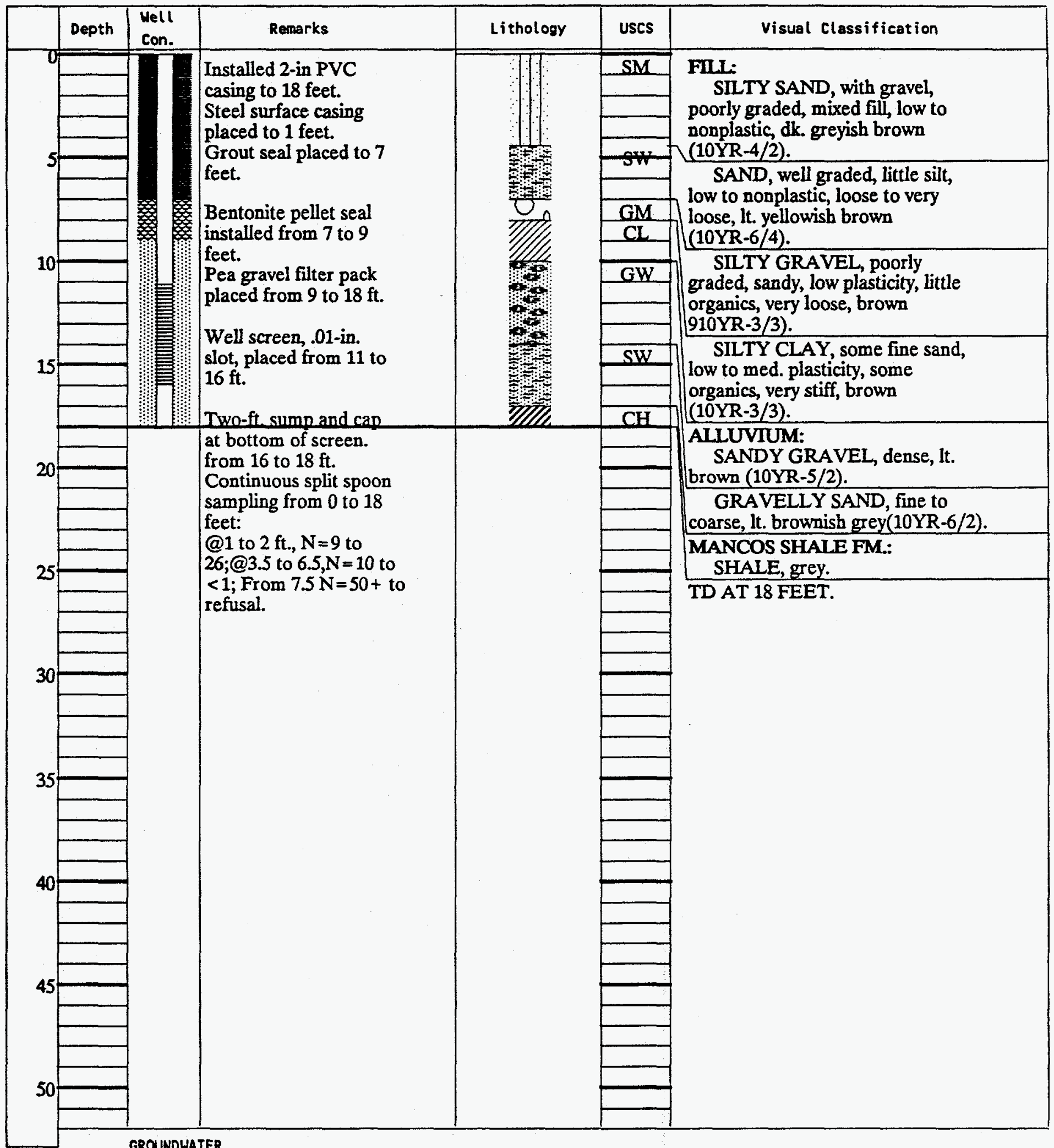

\begin{tabular}{|l|l|l|}
\hline DEPTH & HOUR & DATE \\
\hline & $\nabla$ & \\
\hline \\
\hline
\end{tabular}


PROJECT GRAND JUNCTION PROCESS SITE

\begin{tabular}{ll} 
JOB NO. GRJ01 & \multicolumn{1}{c}{ DATE $\frac{02 / 22 / 85}{\text { BORING TYPE }}$} \\
DEPTH OF SEAL & ROTARY W/ REVERT \\
NELL CASING TYPE & 20.50 \\
\hline COMPLETION & 2.0-IN.SCHED.40 PVC \\
\hline
\end{tabular}

Page 1 of 1

LOG OF WELL BORING NO. 739

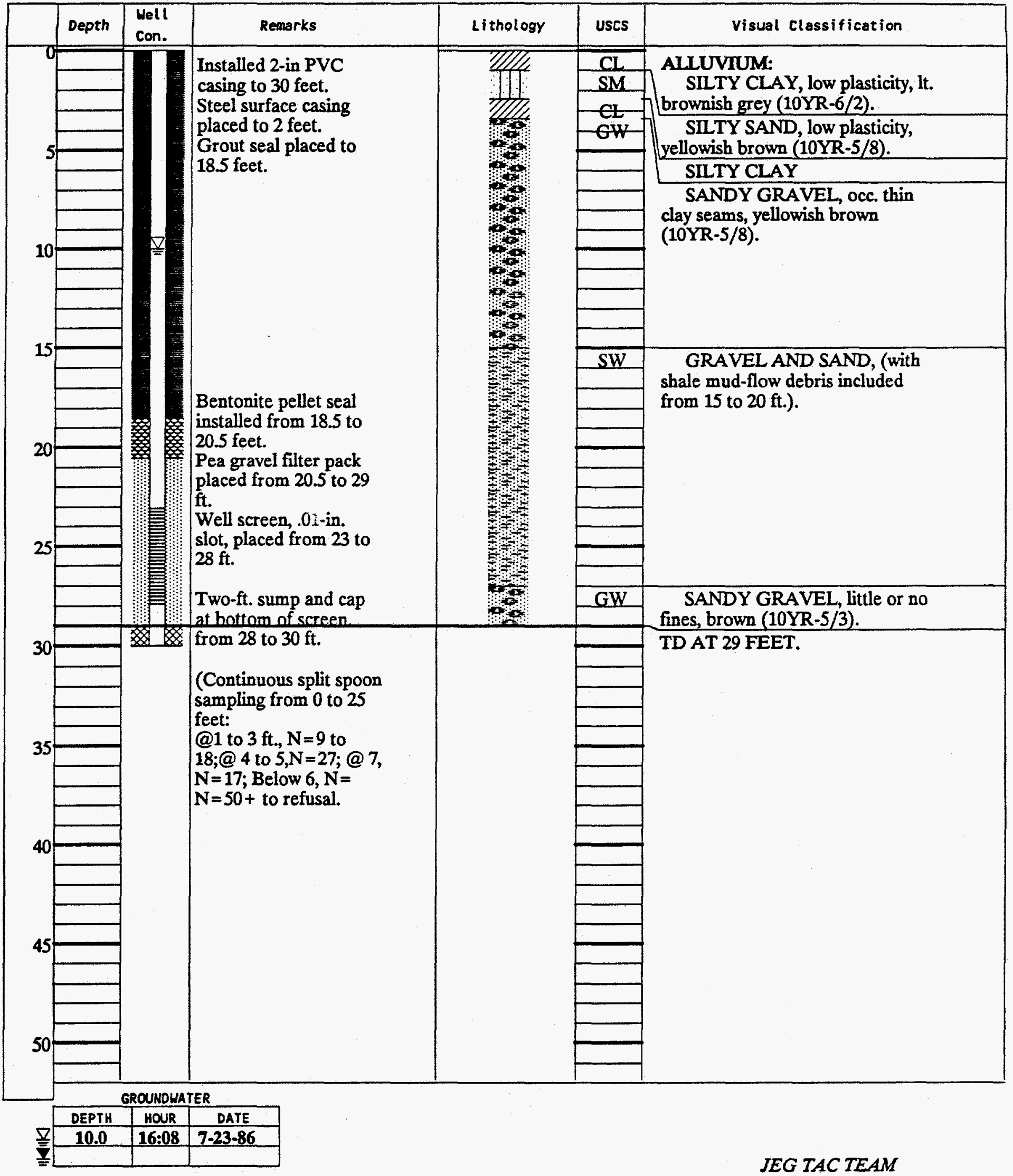

TOTAL DEPTH 30.0 feet

FIELO REP. PMCKenzie

SURFACE ELEVATION $\quad \mathbf{4 5 7 2 . 9 0}$

LOCATION N $60273.60 \quad$ E 31970.10

DATUM MSL 
PROJECT GRAND JUNCTION PROCESS SITE

JOB NO. GRJ01

BORING TYPE

DEPTH OF SEAL

WELL CASING TYPE

CONPLETION

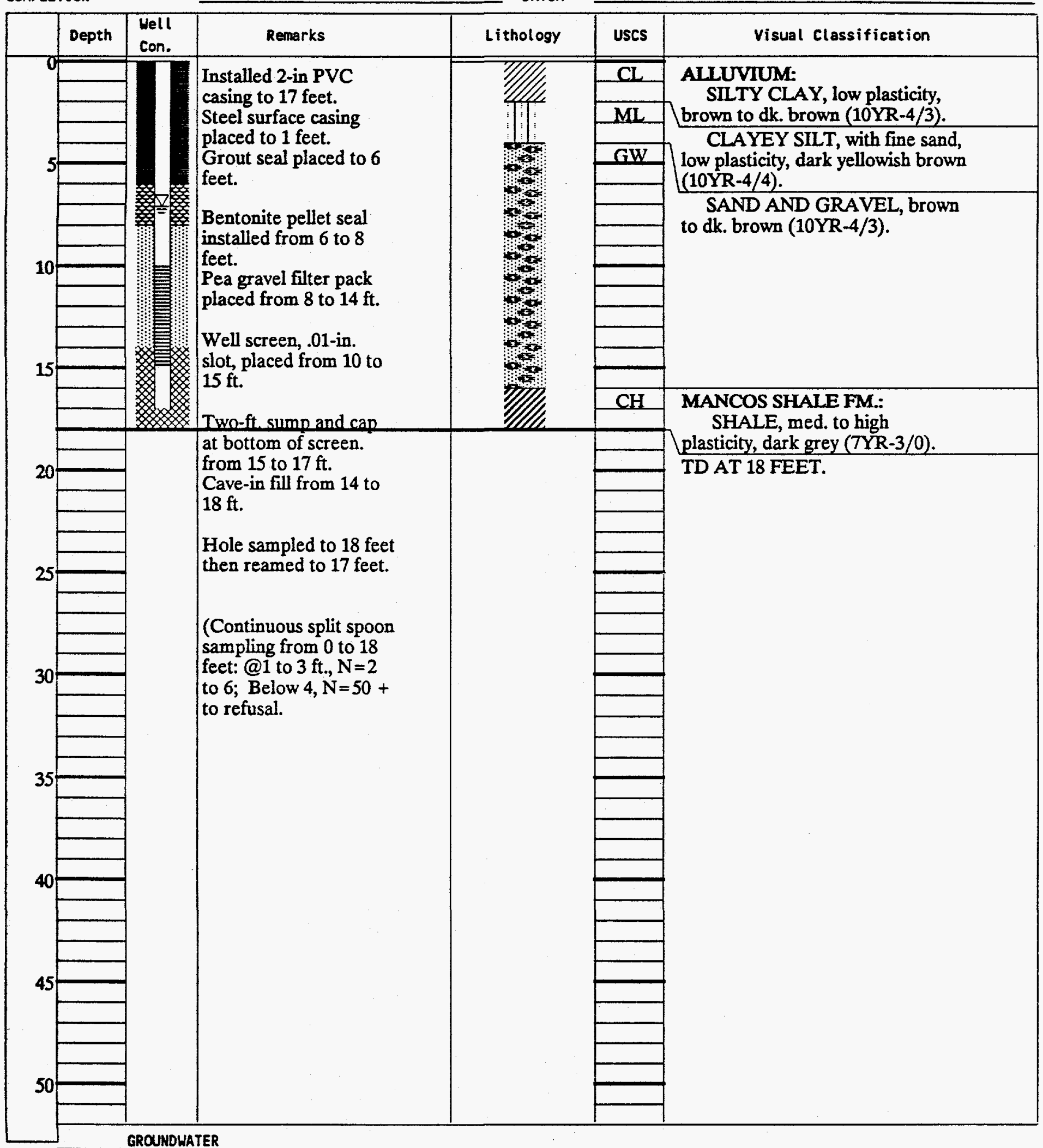

DATE 02/23/85

ROTARY W/ REVERT

8.00

2.0-IN.SCHED.40 PVC

ALLUVIUM
TOTAL DEPTH 18.0 feet

FIELD REP. P.MCKENZIE

SURFACE ELEVATION 4566.10

LOCATION N 59908.30 E 32001.10

MSL

SITY CLAY, low plasticity,

CLAYEY SILT, with fine sand, low plasticity, dark yellowish brown OYR-4/4)

SAND AND GRA

Bentonite pellet seal installed from 6 to 8

Pea gravel filter pack

Well screen, .01-in

slot, placed from 10 to

Two-ft sumn and can

SHALE, med. to high

plasticity, dark grey (7YR-3/0)

from 15 to $17 \mathrm{ft}$

Cave-in fill from 14 to

Hole sampled to 18 feet

(Continuous split spoon

sampling from 0 to 18

to 6; Below 4, N=50 +

\begin{tabular}{|c|c|c|}
\hline DEPTH & HOUR & DATE \\
\hline $\bar{\nabla}$ & $\mathbf{1 5 : 5 0}$ & $\mathbf{7 - 2 3 - 8 6}$ \\
\hline & & \\
\hline
\end{tabular}




\begin{tabular}{ll} 
JOB NO. GRJ01 & \multicolumn{1}{c}{ DATE $\frac{03 / 01 / 85}{}$} \\
BORING TYPE & ROTARY W/AIR-WATER \\
DEPTH OF SEAL & $\begin{array}{l}\text { 31.00 } \\
\text { MELL CASING TYPE } \\
\text { COMPLETION }\end{array}$ \\
\hline & 2.0-IN.SCHED.40 PVC \\
\hline
\end{tabular}

TOTAL DEPTH $\frac{55.5 \text { feet }}{\text { W.WOOD }}$
FIELD REP.
SURFACE ELEVATION
LOCATION
DATUM

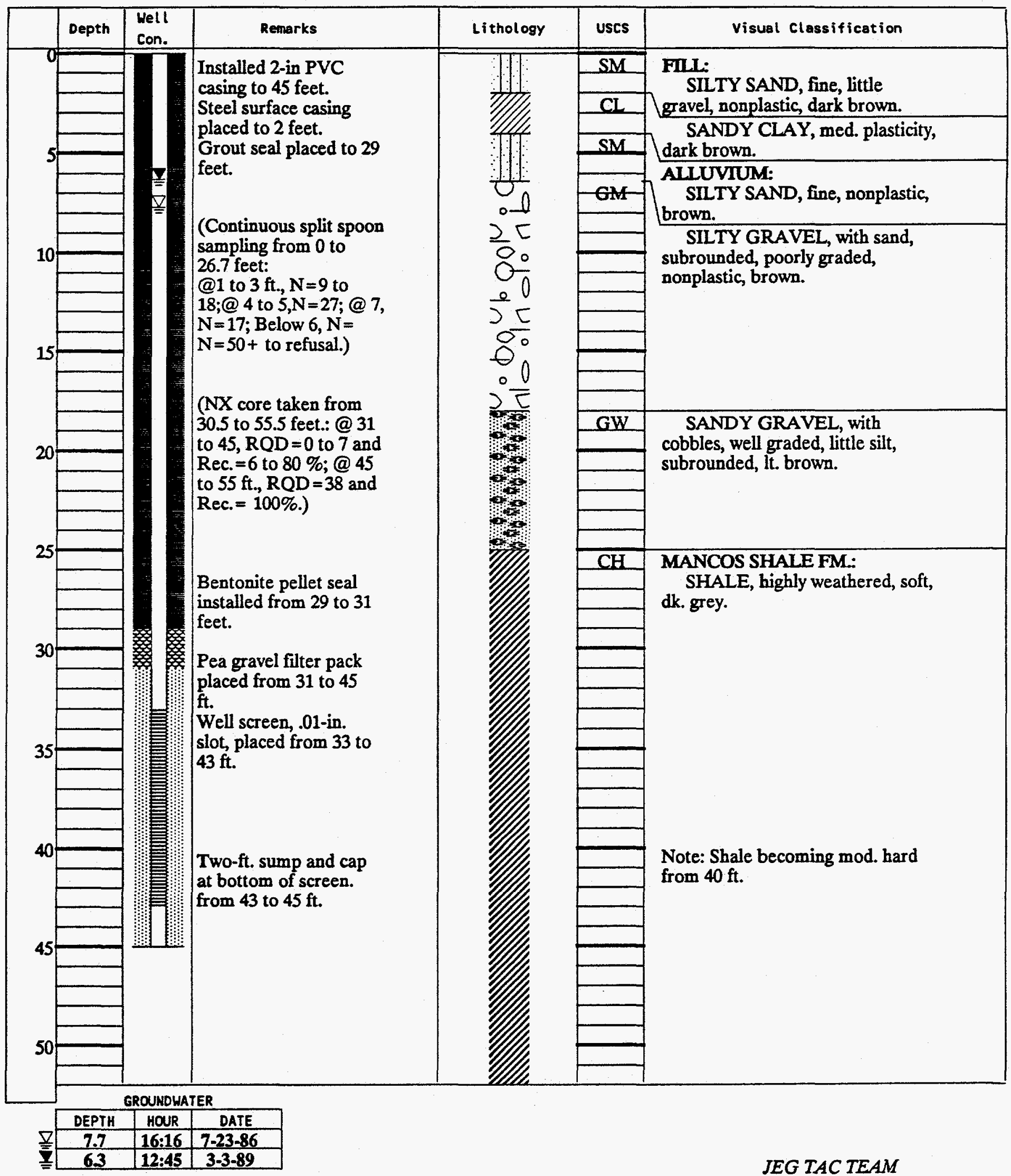


PROJECT GRAND JUNCTION PROCESS SITE

JOB NO. GRJ01

BORING TYPE

DEPTH OF SEAL

MELL CASING TYPE

COMPLETION
DATE 03/01/85

ROTARY W/AIR-WATER

31.00

2.0-IN.SCHED.40 PVC MANCOS SHALE FM.

Page 2 of 2

LOG OF WELL BORING NO.

TOTAL DEPTH $\mathbf{5 5 . 5}$ feet

FIELD REP. W.WOOD

SURFACE ELEVATION $\quad \mathbf{4 5 7 2 . 9 0}$

LOCATION N 60796.00 E 33048.80 DATUM MSL

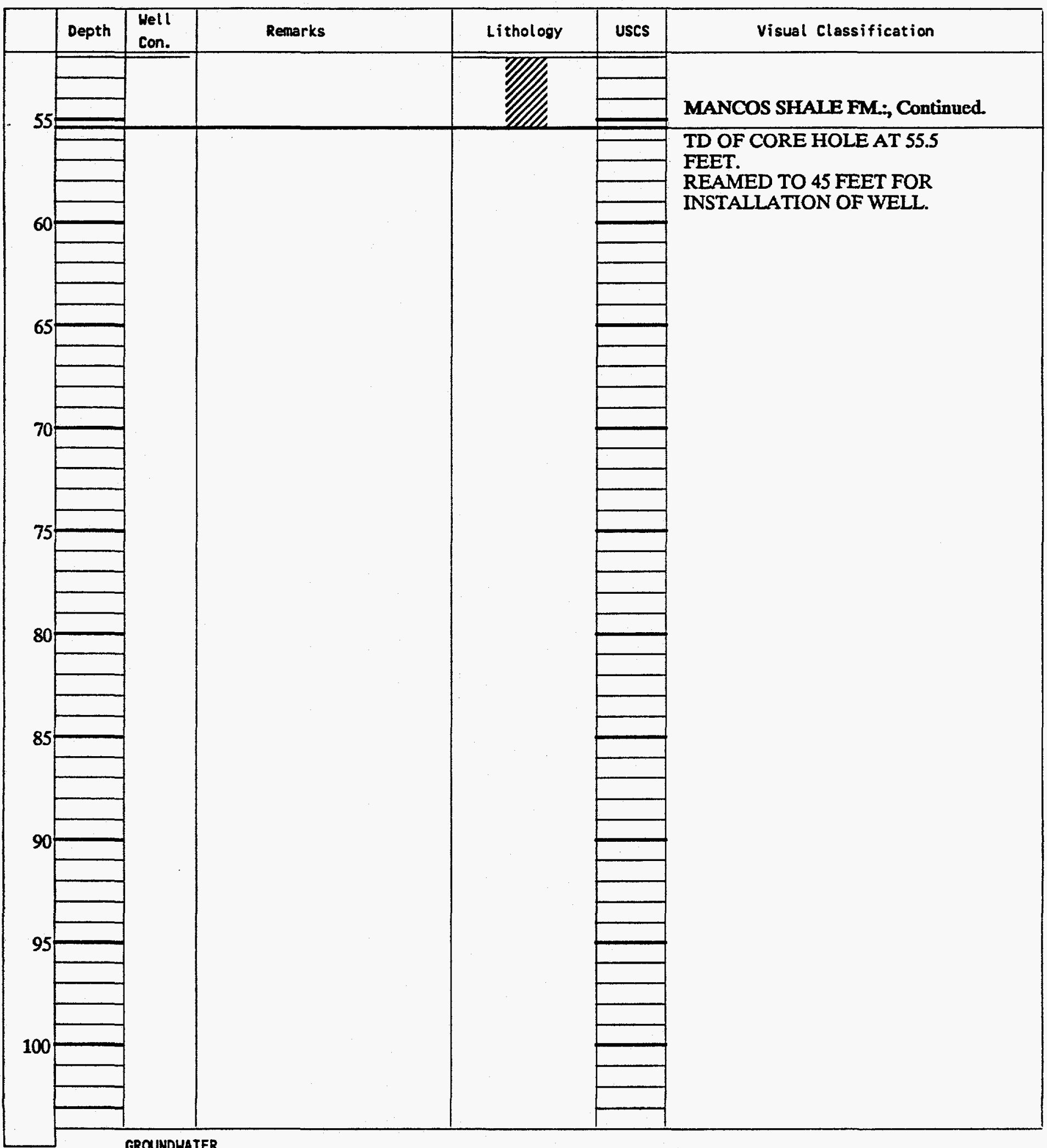

GROUNDWATER

\begin{tabular}{|c|c|c|}
\hline DEPTH & HOUR & DATE \\
\hline 7.7 & $16: 16$ & $7-23-86$ \\
\hline 6.3 & $12: 45$ & $3-3-89$ \\
\hline
\end{tabular}


PROJECT GRAND JUNCTION PROCESS SITE

Page 1 of 1

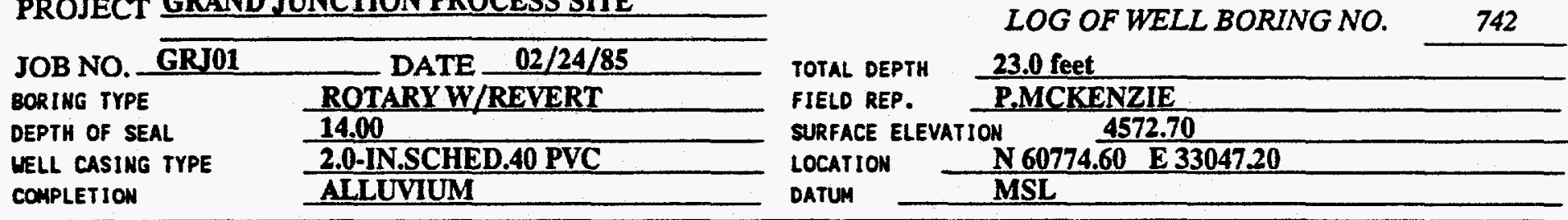

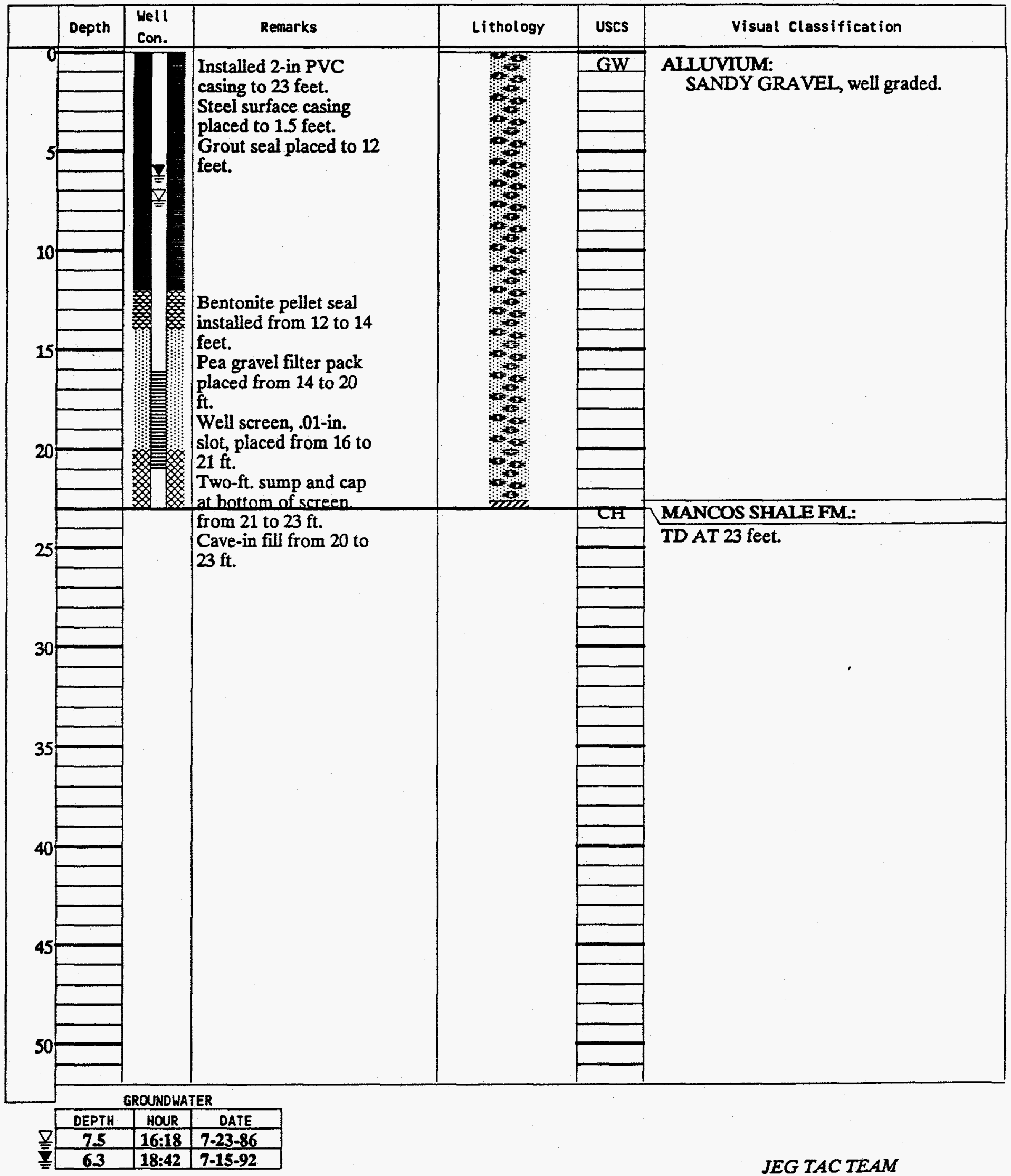




\begin{tabular}{ll} 
JOB NO. GRJ01 & \multicolumn{1}{c}{ DATE $\frac{03 / 02 / 85}{\text { BORING TYPE }}$} \\
$\begin{array}{ll}\text { DEPTH OF SEAL } \\
\text { WELL CASING TYPE } \\
\text { COMPLETION }\end{array}$ & \begin{tabular}{l} 
ROTARY W/AIR \\
\hline
\end{tabular} \\
\hline
\end{tabular}

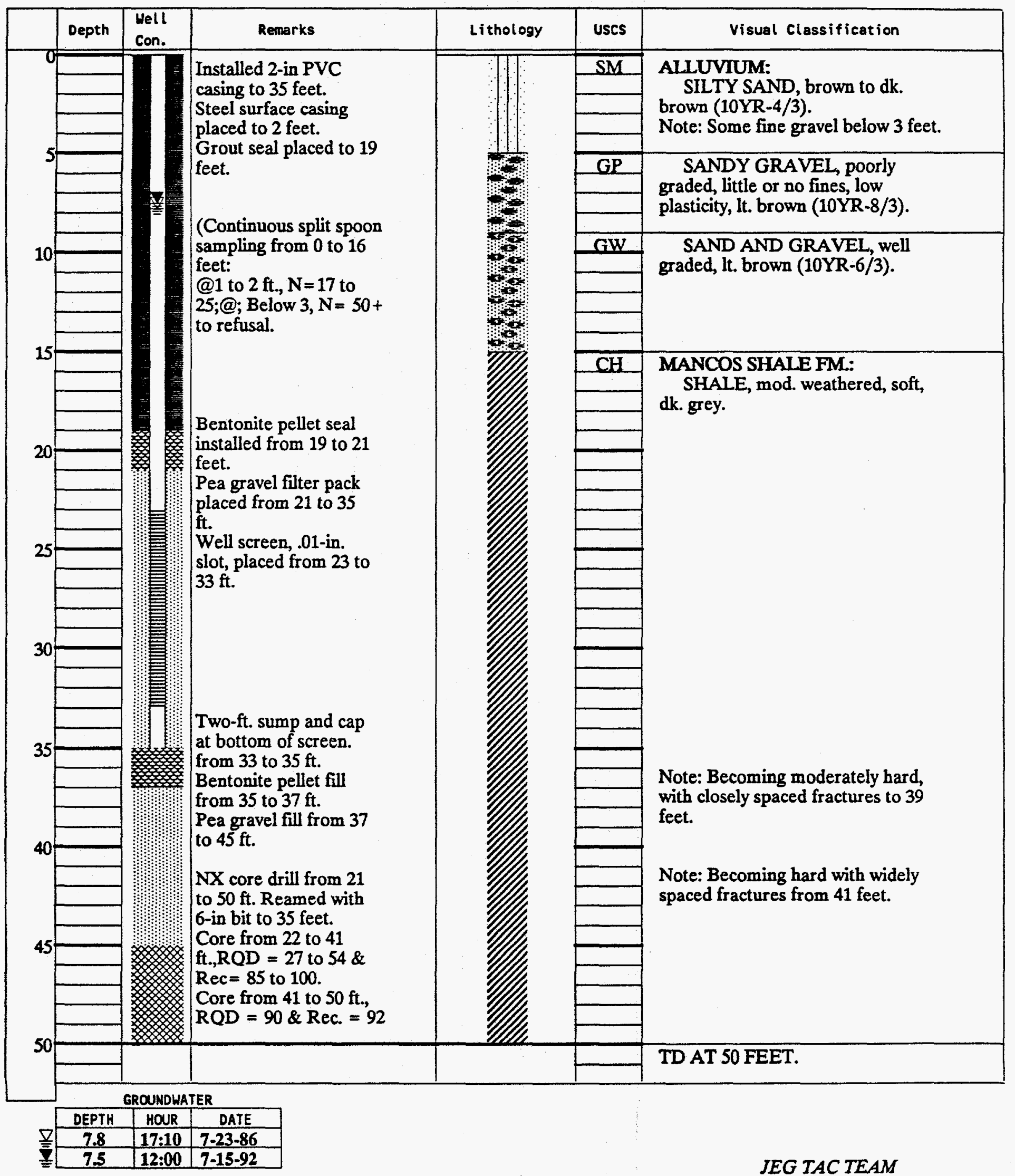

TOTAL DEPTH 50.0 feet

FIELD REP. P.MCKENZIE

SURFACE ELEVATION 4575.10

LOCATION N 59491.70 E 37069.70

DATUM MSL 


\section{PROJECT GRAND JUNCTION PROCESS SITE}

\begin{tabular}{ll}
\hline JOB NO. GRJ01 & \multicolumn{1}{c}{ DATE $02 / 26 / 85$} \\
BORING TYPE & ROTARY W/REVERT \\
DEPTH OF SEAL & 6.00 \\
LELL CASING TYPE & 2.0-IN.SCHED.40 PVC \\
COMPLETION & ALLUVIUM \\
\hline
\end{tabular}

Page 1 of 1

TOTAL DEPTH 15.0 feet

FIELD REP. P.MCKENZIE

SURFACE ELEVATION $\mathbf{4 5 7 4 . 8 0}$

LOCATION N $59492.20 \quad$ E 37051.30

DATUM MSL

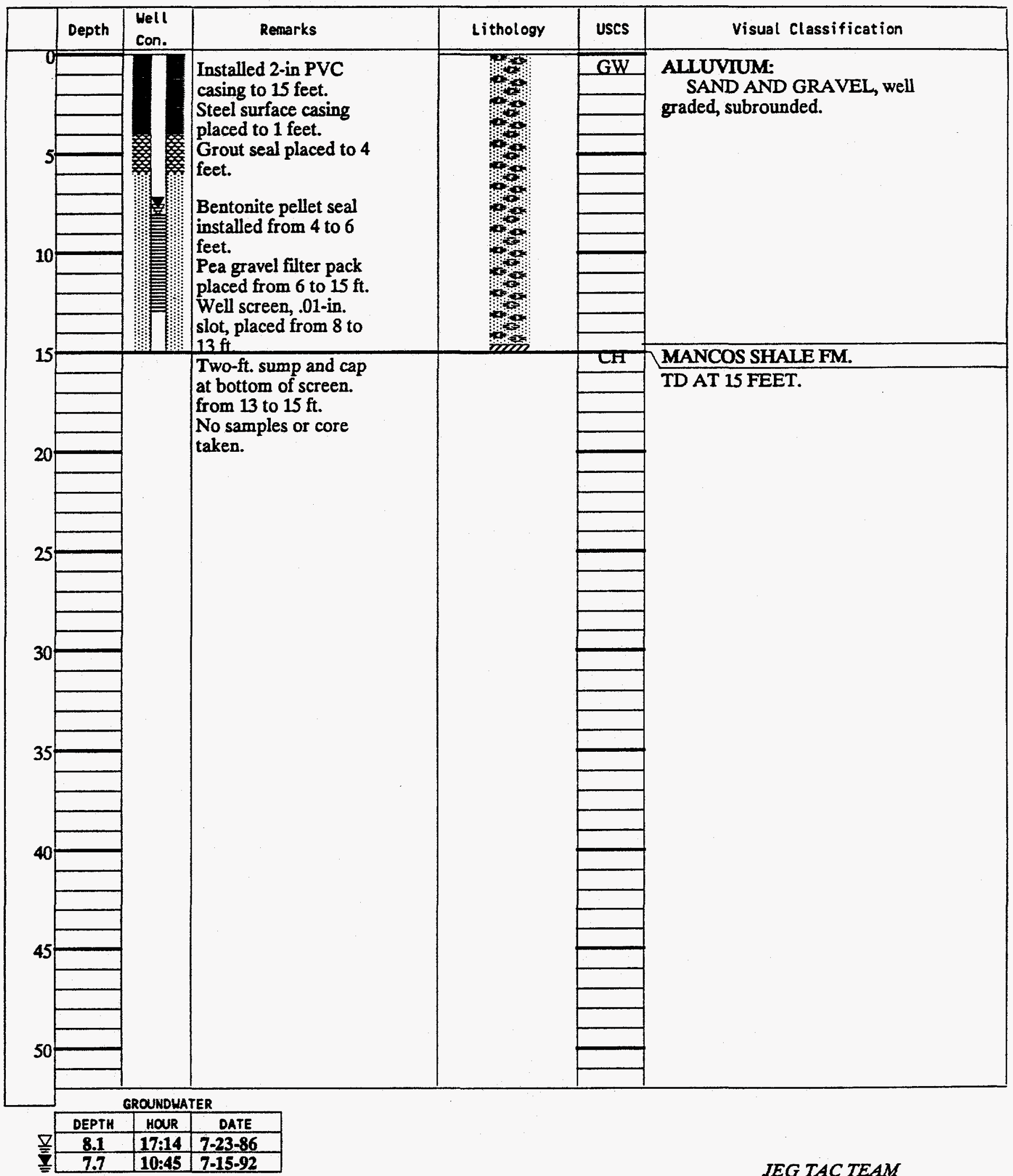




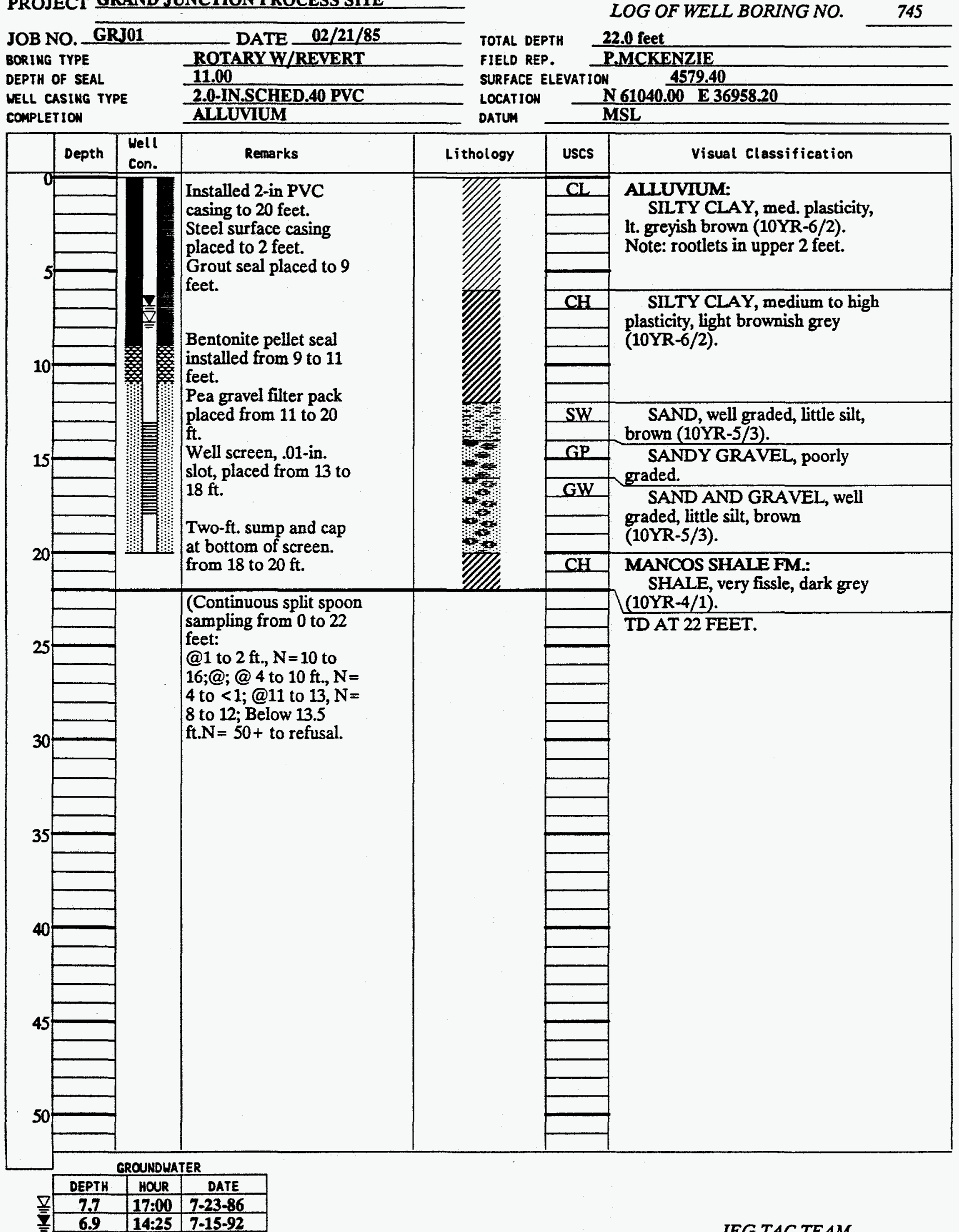


Jacobs Engineering

Albuquerque NM

DATE TIME

At printing SEP1495 10:38

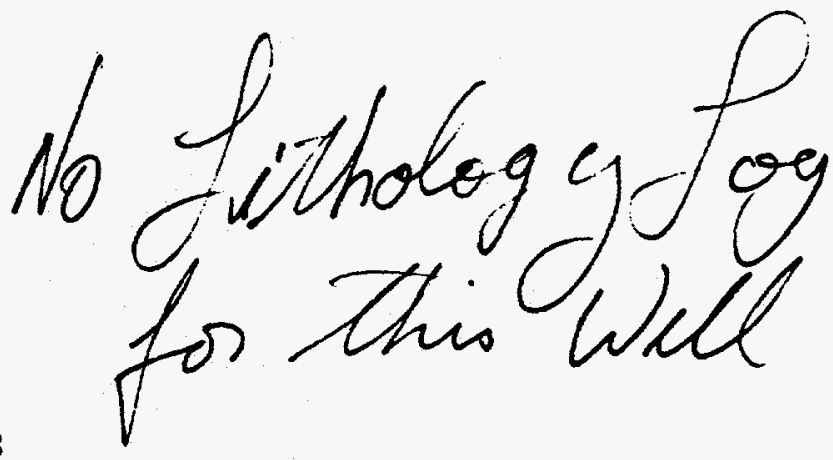

Last update DEC1592 15:41

PROJECT ID GRJOI

POINT ID 746

Exploration Point Definition - ADDRESS 2201

$\{1$ DATES AND COORDINATES $\}$

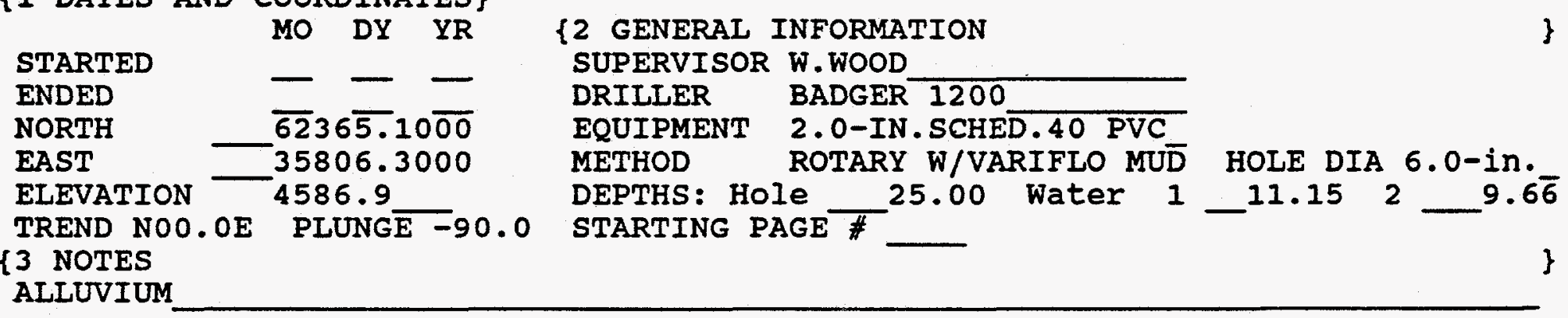

ADDITIONAL NOTE

$\{4$ POINT DESCRIPTOR CODES

TYPE 1

TYPE 2
IOCATION 18

LOCATION 2
\{5 ADDITIONAL DESCRIPTORS

PT.DESC1 16:23

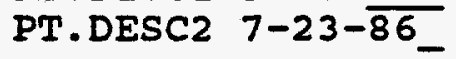

PT.DESC3

PT.DESC4
$15: 37$

7-15- $\overline{92}$ 


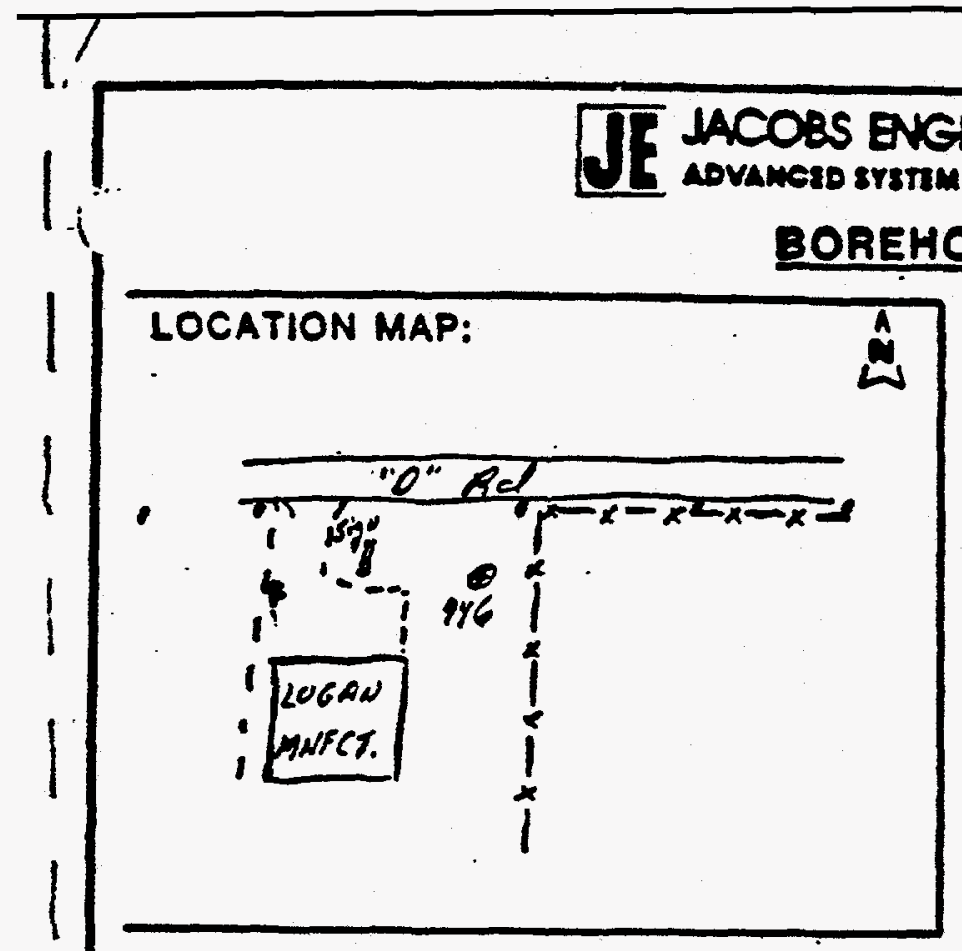

Page L of

LOCATION DESCAIPTION Apree L

SITE CONDITION flat, vafucel beaiere

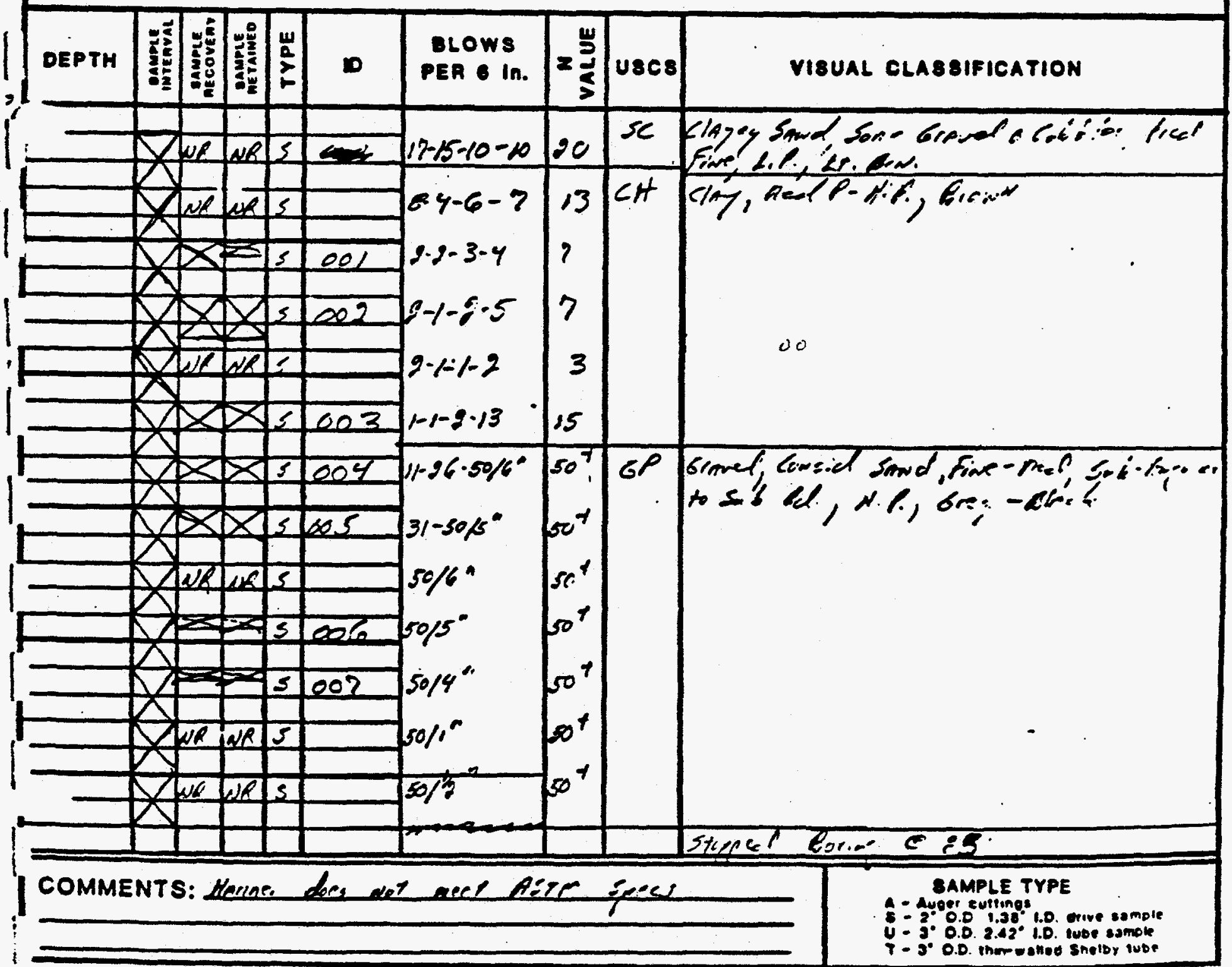


PROJECT GRAND JUNCTION PROCESS SITE

\begin{tabular}{|c|c|}
\hline GRJ01 & $03 / 13 / 85$ \\
\hline BORING TYPE & ROTARY W/VARIFLO MUD \\
\hline DEPTH OF SEAL & 8.00 \\
\hline ISING TYPE & 2.0-IN.SCHED.40 PVC \\
\hline
\end{tabular}

Page 1 of 1 LOG OF WELL BORING NO. 747

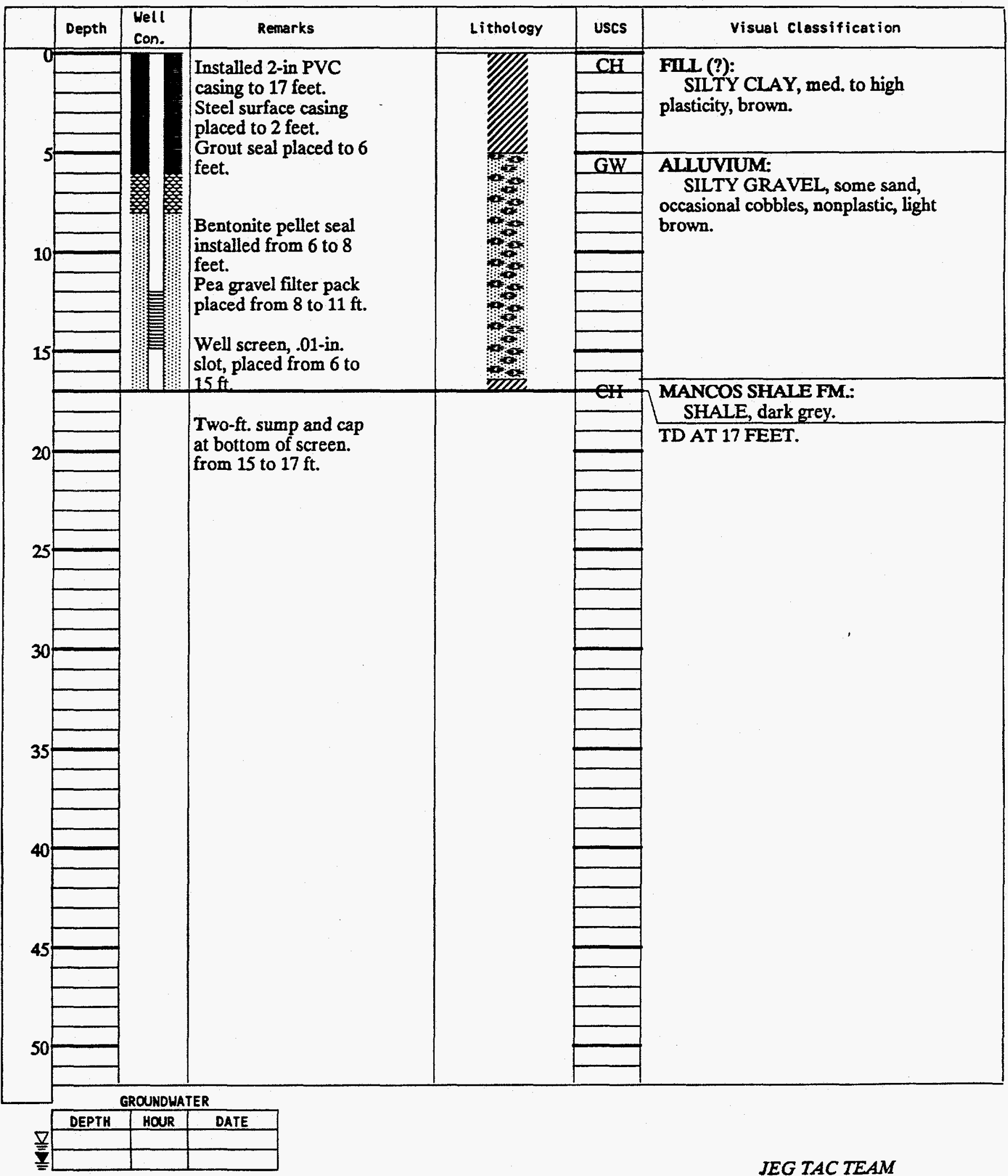


PROJECT GRAND JUNCTION PROCESS SITE

JOB NO. GRJ01

BORING TYPE

DEPTH OF SEAL

WELL CASING TYPE

COMPLETION
DATE 09/28/94

HOLLOW STEM AUGER

3.50

4-IN.SCHED. 40 PVC

ALLUVIUM
Page 1 of 1

LOG OF WELL BORING NO.

1000

TOTAL DEPTH 93 feet

FIELD REP. T.MONKS

SURFACE ELEVATION $4566.86 \quad$ TTOC $=\mathbf{4 5 6 8 . 8 2}$

LOCATION N 59345.13 E 32891.49

DATUM MSL

\begin{tabular}{|c|c|c|c|c|c|c|}
\hline & Depth & $\begin{array}{l}\text { Well } \\
\text { Con. }\end{array}$ & Remarks & Lithology & uscs & Visual Classification \\
\hline \multirow[t]{6}{*}{0} & & \multirow{6}{*}{$\frac{1}{12}$} & \multirow{6}{*}{$\begin{array}{l}\text { Placed } 4 \text {-inch sched. } 40 \\
\text { PVC to } 8.8 \text { feet. } \\
\text { Installed steel protective } \\
\text { casing and cement grout to } \\
2 \text { feet. } \\
\text { Bentonite pellet seal placed } \\
\text { from } 2 \text { to } 3.5 \text { feet. }\end{array}$} & \multirow{6}{*}{ 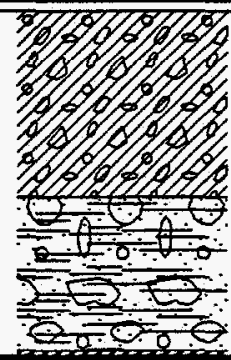 } & GC & \multirow{3}{*}{$\begin{array}{l}\text { ALLUVIUM: } \\
\text { CLAYEY GRAVEL, some silt, } \\
\text { about } 40 \% \text { fine sand, } 10 \% \\
\text { subrounded to angular, moderate } \\
\text { plasticity, mod. calcareous, pale } \\
\text { yellowish brown }(10 \mathrm{Y}, 6 / 2) \text {. }\end{array}$} \\
\hline & & & & & & \\
\hline & & & & & & \\
\hline & & & & & GM & \multirow{3}{*}{$\begin{array}{l}\text { SILTY GRAVEL AND COBBLES, } \\
\text { subrounded to angular gravel } \\
\text { cobbles to 4-inch } 20 \% \text { silt, slightly } \\
\text { plastic, moderately calcareous, pale } \\
\text { vellowish brown }(10 \text { Y } 6 \text { R } 6 / 2) \text {. }\end{array}$} \\
\hline & & & & & & \\
\hline & & & & & & \\
\hline \multirow[t]{4}{*}{10} & & & \multirow{31}{*}{$\begin{array}{l}\text { \#20/40 sand filter pack } \\
\text { placed from } 3.5 \text { to } \mathrm{TD} \text {. } \\
\text { Installed screen from } 3.8 \\
\text { to } 8.8 \text { feet. }\end{array}$} & & $\mathrm{CH}$ & TD AT 9.24 ON MANCOS SHALE \\
\hline & & & & & & \\
\hline & & & & & & \\
\hline & & & & & & \\
\hline \multirow[t]{3}{*}{15} & & & & & & \\
\hline & & & & & & \\
\hline & & & & & & \\
\hline \multirow{4}{*}{20} & & & & & & \\
\hline & & & & & & \\
\hline & & & & & & \\
\hline & & & & & & \\
\hline \multirow{3}{*}{25} & & & & & & \\
\hline & & & & & & \\
\hline & & & & & & \\
\hline \multirow{3}{*}{30} & & & & & & \\
\hline & & & & & & \\
\hline & & & & & & \\
\hline \multirow{4}{*}{35} & & & & & & \\
\hline & & & & & & \\
\hline & & & & & & \\
\hline & & & & & & \\
\hline \multirow{3}{*}{40} & & & & & & \\
\hline & & & & & & \\
\hline & & & & & & \\
\hline \multirow{4}{*}{45} & & & & & & \\
\hline & & & & & & \\
\hline & & & & & & \\
\hline & & & & & & \\
\hline \multirow{3}{*}{50} & & & & & & \\
\hline & & & & & & \\
\hline & & & & & & \\
\hline
\end{tabular}

GROUNDWATER

\begin{tabular}{|c|c|c|}
\hline DEPTH & HOUR & DATE \\
\hline 3.3 & $18: 30$ & $9 / 27 / 94$ \\
\hline & & \\
\hline \hline
\end{tabular}


PROJECT GRAND JUNCTION PROCESS SITE

\begin{tabular}{ll}
\hline JOB NO. GRJ01 & \multicolumn{1}{c}{ DATE 09/29/94 } \\
BORING TYPE & HOLLOW STEM AUGER \\
DEPTH OF SEAL & 5.00 \\
WELL CASING TYPE & 4-IN.SCHED.40 PVC \\
COMPLETIOW & ALLUVIUM \\
\hline
\end{tabular}

Page 1 of 1

LOG OF WELL BORING NO.

1001

TOTAL DEPTH 12.1 feet

FIELD REP. T.MONKS

SURFACE ELEVATION $\quad \mathbf{4 5 7 0 . 4 1}$ GTOC= $\mathbf{4 5 7 1 . 6 6}$

LOCATION N 59419.40 E 32986.28

DATUM MSL

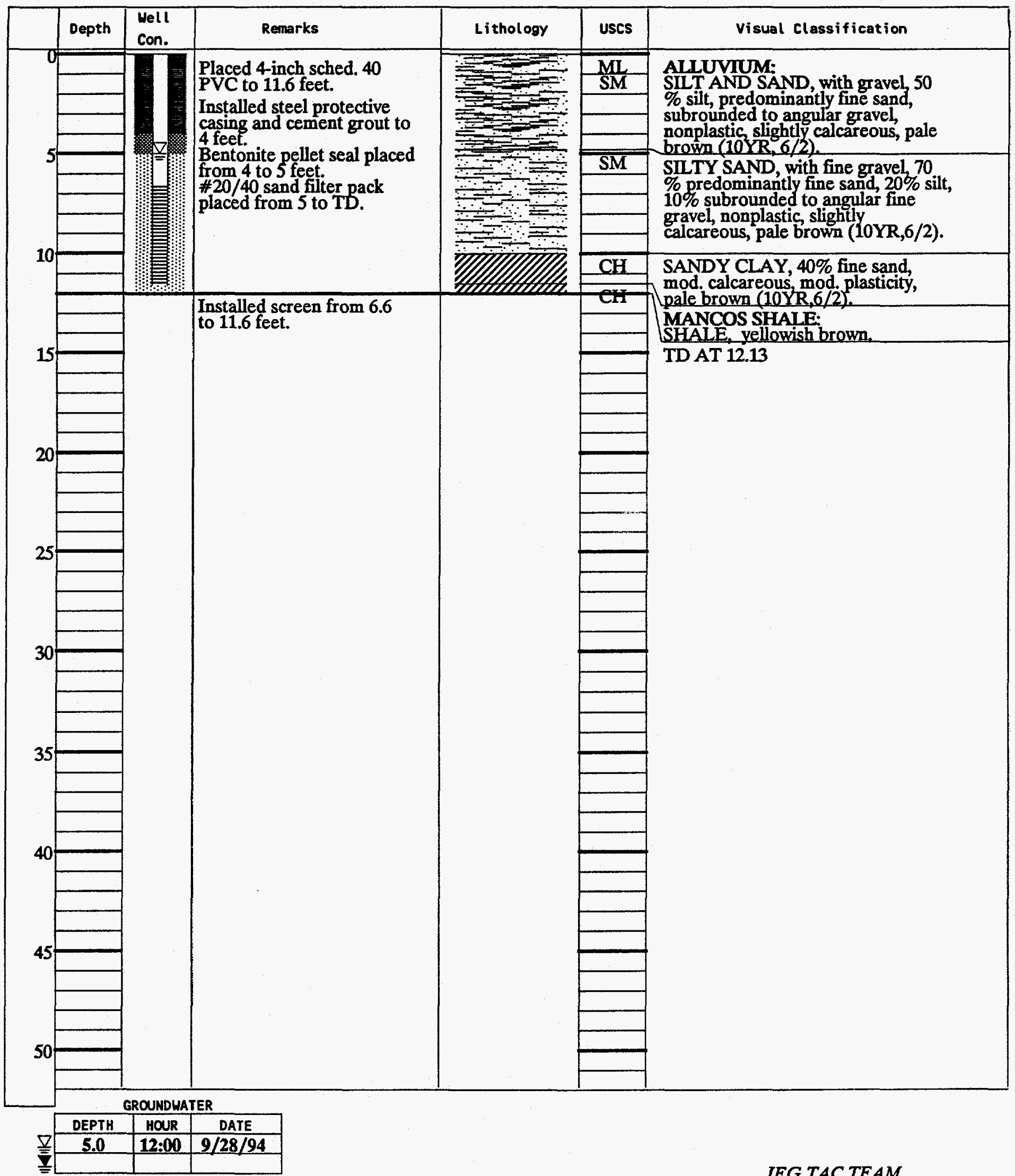




\section{PROJECT GRAND JUNCTION PROCESS SITE}

JOB NO. GRJ01 DATE 09/29/94

BORING TYPE

DEPTH OF SEAL

WELL CASING TYPE

COMPLETION
HOLLOW STEM AUGER

5.00

4-IN.SCHED. 40 PVC

ALLUVIUM

Page 1 of 1

LOG OF WELL BORING NO. 1002

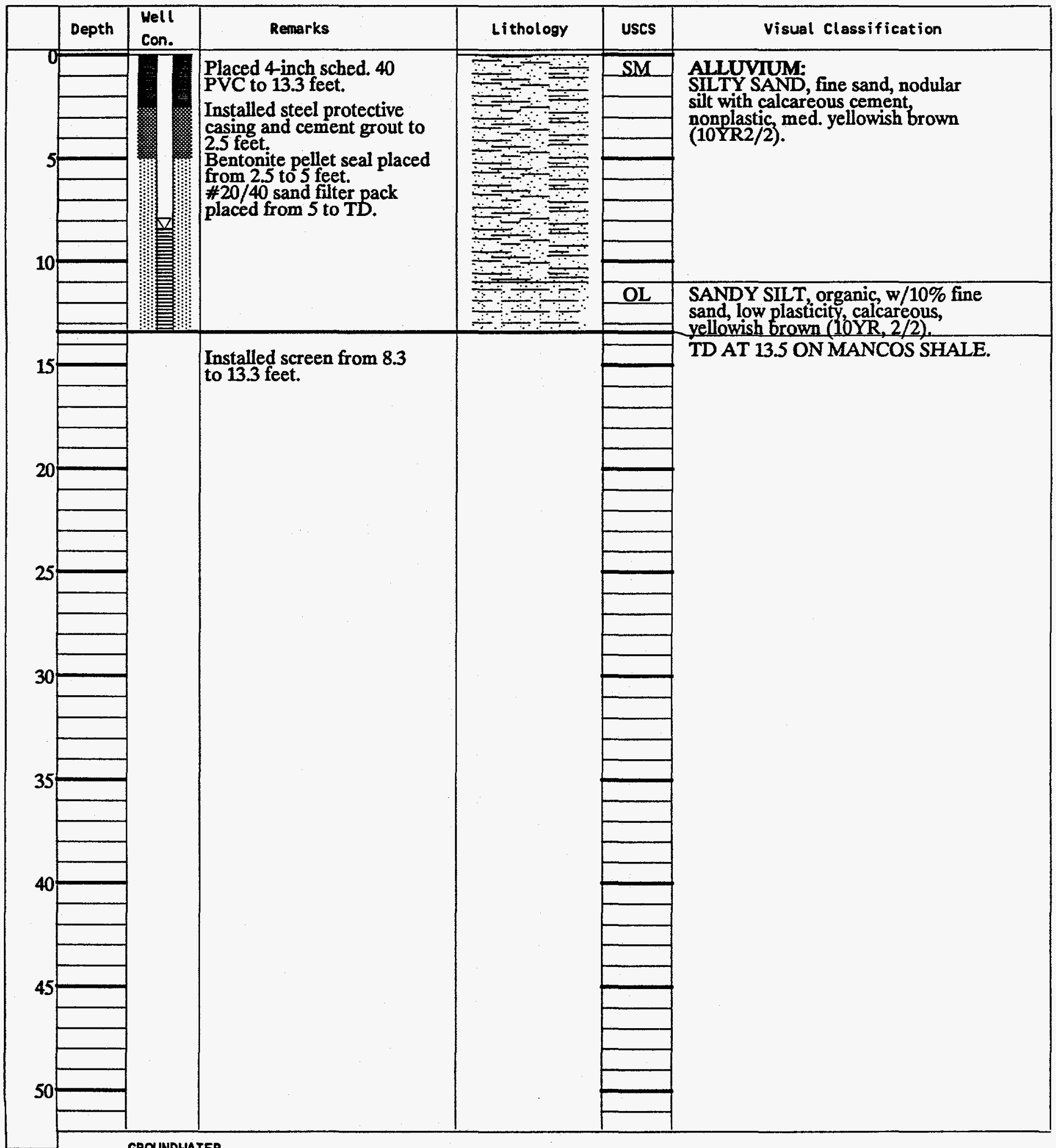

GROUNDWATER

\begin{tabular}{|c|c|c|}
\hline DEPTH & HOUR & DATE \\
\hline $\bar{\nabla}$ & $\mathbf{1 4 : 2 0}$ & $9 / 28 / 94$ \\
\hline & & \\
\hline
\end{tabular}


APPENDIX B

TOXICITY RANGES 
Figure B1

Chloride Toxicity Ranges
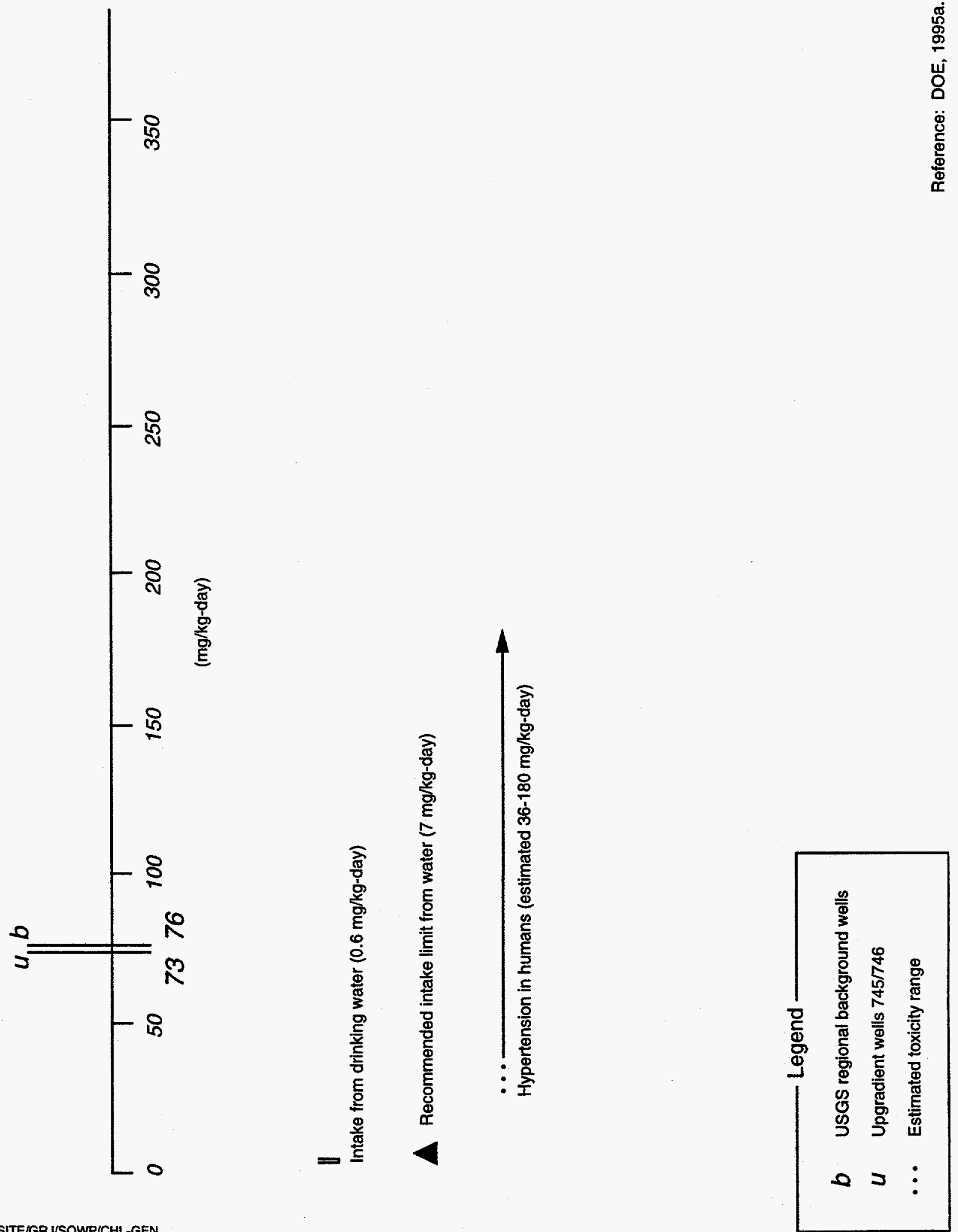


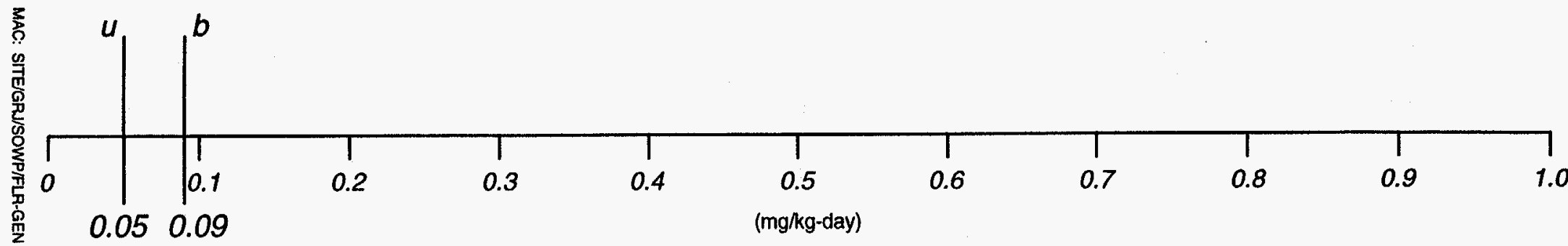

I Average dietary intake level from food ....

Intake levels from drinking water

L...

No observable effect level for dental fluorosis

$$
\because-\cdots
$$

Dental mottling and changes in tooth structure in children - objectionable dental fluorosis

$\Delta$

Oral Reference Dose (food and drinking water) $(0.06 \mathrm{mg} / \mathrm{kg}$-day)

Increasing dental mottling with increasing intake in children

No observable effect level for skeletal fluorosis in adults

Crippling skeletal fluorosis in adults $(0.29-1.1 \mathrm{mg} / \mathrm{kg}$-day)

Legend

b USGS regional background wells

u Upgradient wells $745 / 746$

-.. Estimated toxicity range 


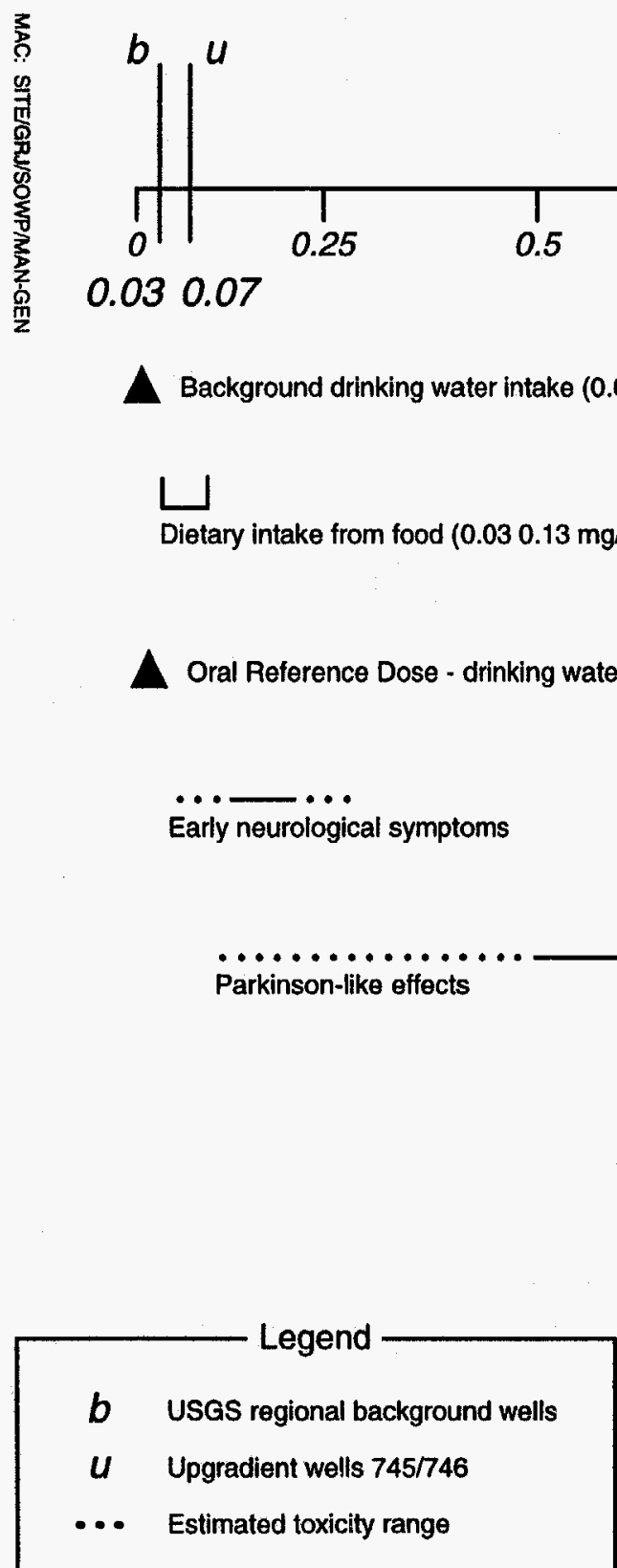

Acute lethal dose, rodents (400-800 $\mathrm{mg} / \mathrm{kg}$ )

USGS regional background wells

-. Estimated toxicity range 


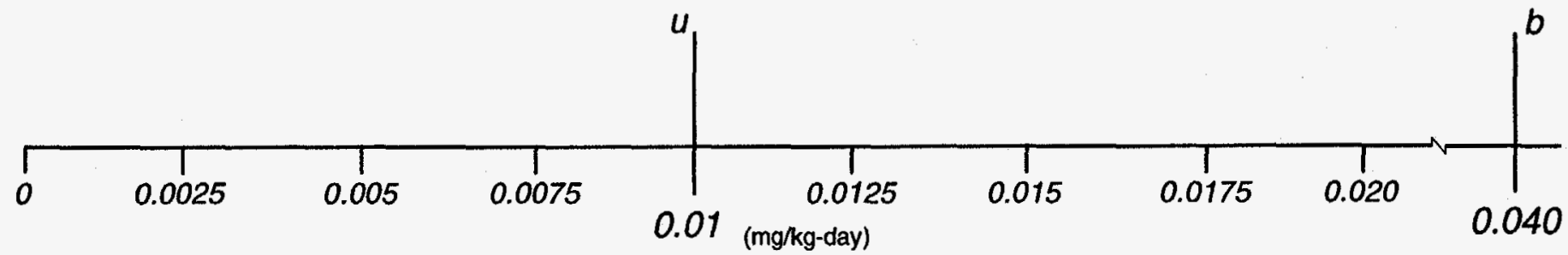

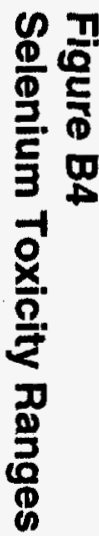

Dietary intake levels $(0.021 \mathrm{mg} / \mathrm{kg}$-day, adult men)

$\triangle$ Oral Reference Dose (0.005 mg/kg-day)

No observed effect level

Mild toxicity - nail and hair brittleness/oss $(0.071 \mathrm{mg} / \mathrm{kg}$-day $)$

Legend

b USGS regional background wells

$u$ Upgradient wells $745 / 746$

... Estimated toxicity range 
Figure B5

Sodium Toxicity Ranges

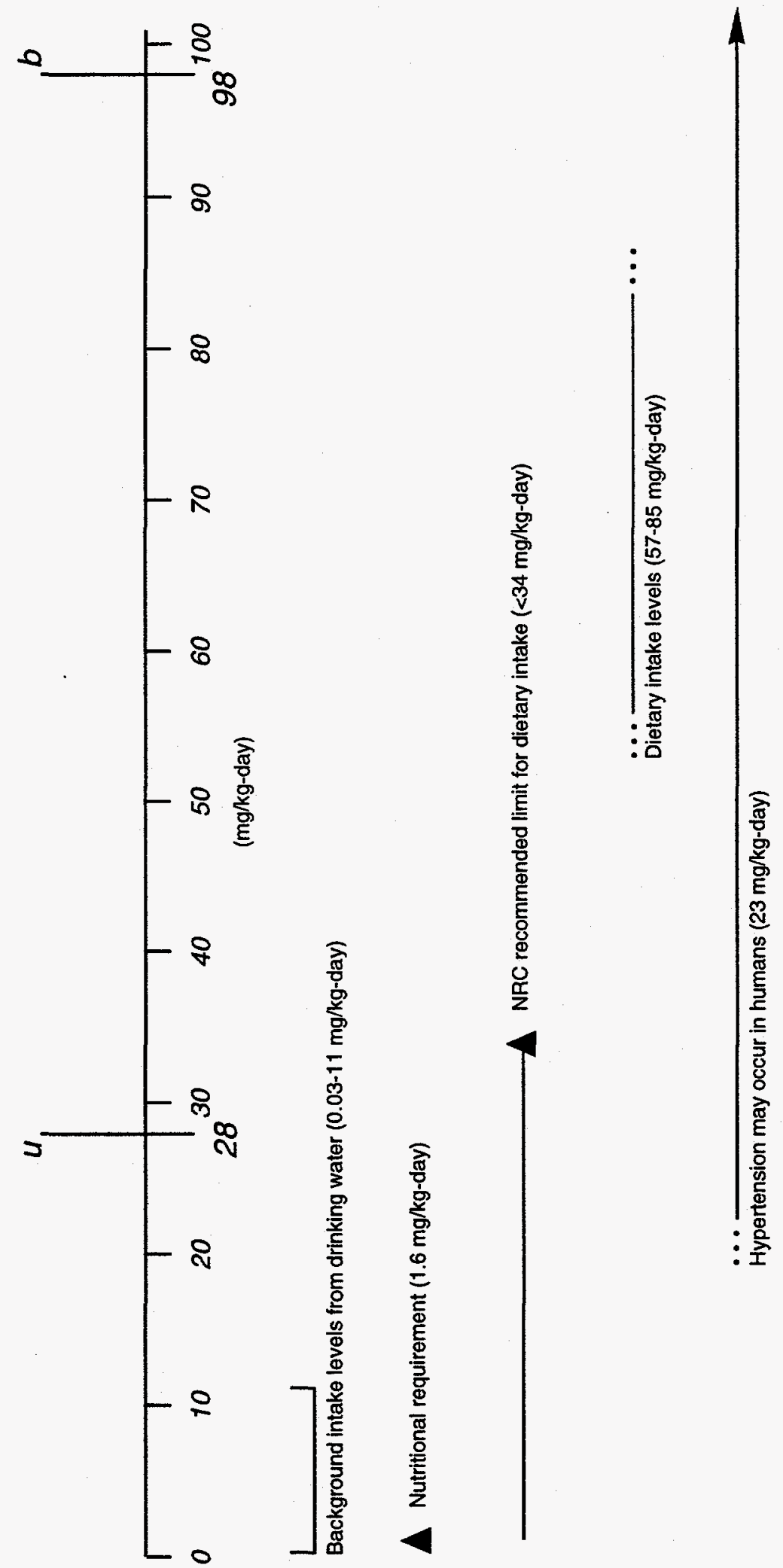

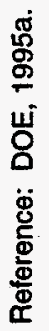

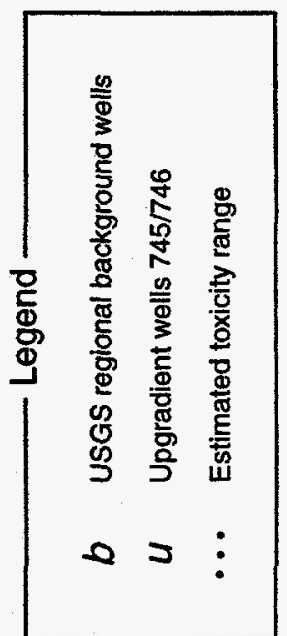


Background intake levels (0-2.9 mg/kg-day)

ㄴo.... observed effects

Mild toxicity ranging from laxative effect (adults) to diarrhea in infants

Sëvere toxicity - persistent infant diarrhea leading to dehydration ....- death

Legend

b USGS regional background wells

$u$ Upgradient wells $745 / 746$

... Estimated toxicity range 


\section{REFERENCES}

DOE (U.S. Department of Energy), 1995a. Baseline Risk Assessment of Ground Water Contamination at the Uranium Mill Tailings Site at Grand Junction, Colorado, DOE/AL/62350-104, Rev. 2, prepared for the U.S. Department of Energy, Environmental Restoration Division, UMTRA Project Team, Albuquerque, New Mexico.

DOE (U.S. Department of Energy), 1995b. Baseline Risk Assessment of Ground Water Contamination at the Uranium Mill Tailings Site Near Slick Rock, Colorado, DOE/AL/62350-147, Rev. 1, prepared for the U.S. Department of Energy, Environmental Restoration Division, UMTRA Project Team, Albuquerque, New Mexico. 